
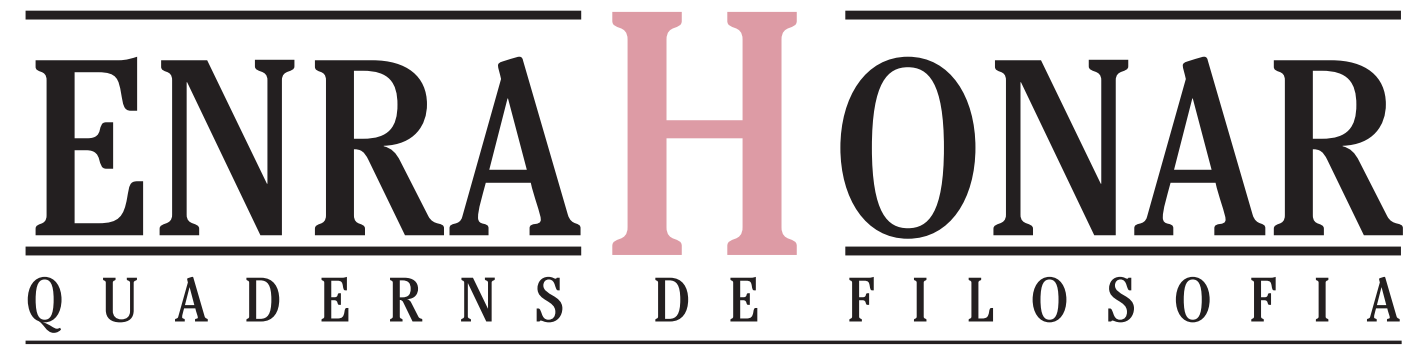

Q U A D E R N S

D E

F I L 0 O 5 S 0 O F I A

AN INTERNATIONAL JOURNAL OF THEORETICAL AND PRACTICAL REASON

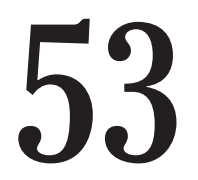

\title{
Ètica i política del paisatge
}

Carmen Velayos (coord.) 
Equip de direcció

Jaume Mensa, director (UAB)

Jordi Riba (UAB)

Thomas Sturm (UAB)

Andreu Ballús, secretari (UAB)

\section{Consell de redacció}

Victòria Camps Cervera (UAB)

Manuel Cruz (Universitat de Barcelona)

Anna Estany Profitós (UAB)

Víctor Gómez Pin (UAB)

Carl Hoefer (University of Western Ontario)

David Jou Mirabent (UAB)

Laura Llevadot (Universitat de Barcelona)

Joan-Carles Mèlich Sangrà (UAB)

Àngel Puyol (UAB)

Daniel Quesada Casajuana (UAB)

Marta Tafalla (UAB)

Josep M. Terricabras Noguera (Universitat de Girona)

Joan Vergés (Universitat de Girona)

Gerard Vilar (UAB)

\section{Consell editorial}

Francisco Bertelloni (Universidad de Buenos Aires)

Paula Casal (ICREA, Universitat Pompeu Fabra)

Jordi Cat (University of Indiana)

Alexander García-Düttmann (University of London)

María Herrera (Universidad Nacional Autónoma de México)

Patricia Kitcher (Columbia University)

Cristina Lafont (Northwestern University)

Christoph Menke (Goethe-Universität Frankfurt)

Carlos Moya (Universidad de Valencia)

Julián Pacho (Universidad del País Vasco)

Carlos Pereda (Universidad Nacional Autónoma de México)

Francisca Pérez Carreño (Universidad de Murcia)

Manuel Pérez Otero (Universidad de Barcelona)

Yves Sintomer (Université Paris 8)

Mauricio Suárez (Universidad Complutense de Madrid)

Carlos Thiebaut (Universidad Carlos III)
Secretari

David Hernández Abajo (UAB)

Redacció

Universitat Autònoma de Barcelona

Departament de Filosofia

08193 Bellaterra (Barcelona). Spain

Tel.: 9358116 18. Fax: 935812001

revista.enrahonar@uab.cat

http://revistes.uab.cat/enrahonar

Subscripció i administració

Universitat Autònoma de Barcelona

Servei de Publicacions

08193 Bellaterra (Barcelona). Spain

Tel.: 9358110 22. Fax: 935813239

sp@uab.cat

Intercanvi

Universitat Autònoma de Barcelona

Servei de Biblioteques

Secció d'Intercanvi de Publicacions

08193 Bellaterra (Barcelona). Spain

Tel.: 9358111 93. Fax: 935813219

sb.intercanvi@uab.cat

Composició: Mercè Roig

Edició i impressió

Universitat Autònoma de Barcelona

Servei de Publicacions

08193 Bellaterra (Barcelona). Spain

Tel.: 9358121 31. Fax: 935813239

sp@uab.cat

http://publicacions.uab.cat/

ISSN 0211-402X (paper)

ISSN 2014-881X (digital)

Dipòsit legal: B. 13.550-1981

Imprès a Espanya. Printed in Spain

Imprès en paper ecològic

ENRAHONAR és una revista acadèmica de filosofia fundada l'any 1981 i editada per la Universitat Autònoma de Barcelona (Departament de Filosofia). Enrahonar, com el mot català «enra(h)onar», reivindica alhora diàleg i raó, i posa un interès especial en les contribucions relacionades en certa manera amb la raó o la racionalitat teòrica i pràctica (enteses en aquest sentit genuí esmentat) en tots els seus aspectes i en totes les disciplines filosòfiques, com l'epistemologia, l'ètica, l'estètica, la metafísica, la filosofia de la ciència o la filosofia del llenguatge, de la ment, de l'acció, i també en els plantejaments històrics. Un tema preferent de recerca és la filosofia catalana. L'acceptació d'articles es regeix pel sistema de censors (double blind peer review), amb avaluadors externs. ENRAHONAR també publica notes bibliogràfiques i ressenyes i convida a presentar propostes de números monogràfics. EnRAHONAR té una periodicitat semestral (març i octubre). Tots els articles, notes i ressenyes es poden consultar i descarregar gratuïtament. Les normes del procés de revisió i les instruccions per als autors es poden consultar a: http://revistes.uab.cat/enrahonar/about

La revista EnRAhonar ha estat successivament dirigida per Josep Calsamiglia, Josep Montserrat Torrents, Victòria Camps, Gerard Vilar i Marta Tafalla.

Les opinions expressades en articles, notes, ressenyes o altres treballs publicats a ENRAHONAR són d'exclusiva responsabilitat dels seus autors.

\section{Bases de dades en què EnRAHONAR està referenciada}

\begin{tabular}{|c|c|c|}
\hline $\begin{array}{l}\text {-CARHUS Plus+ } \\
\text { —CiteFactor } \\
\text { —Clasificación Integrada de } \\
\text { Revistas Científicas (CIRC) } \\
\text { —COPAC } \\
\text { —-Dialnet (Unirioja) } \\
\text { —DICE-CINDOC } \\
\text {-Dipòsit Digital de Documents } \\
\text { de la UAB (DDD) }\end{array}$ & $\begin{array}{l}\text {-Directori of Open Access Journals } \\
\text { (DOAJ) } \\
\text { —Índice Español de Ciencias Sociales } \\
\text { y Humanidades (ISOC-CSIC) } \\
\text { —Latindex } \\
\text { —MIAR } \\
\text { - Periodical Index Online } \\
\text {-The Philosopher's Index } \\
\text { - Regesta Imperii }\end{array}$ & $\begin{array}{l}\text { - Répertoire Bibliographique } \\
\text { de la Philosophie } \\
\text { —-RESH } \\
\text { —-Revistes Catalanes d'Accés Obert } \\
\text { (RACO) } \\
\text { - SUDOC } \\
\text {-ULRICH'S } \\
\text {-ZDB }\end{array}$ \\
\hline
\end{tabular}

Enrahonar es publica sota el sistema de llicències Creative Commons segons la modalitat:

Reconeixement - NoComercial (by-nc): Es permet la generació d'obres derivades sempre que no se'n faci un ús comercial. Tampoc es pot utilitzar l'obra original amb finalitats comercials. 
Enraonar: «Discutir o examinar en una conversa»

"Discutir o examinar en una conversación"

"To discuss or examine in conversation"

Enrahonar: «El manteniment arcaic de la h suggereix la riquesa semàntica i la càrrega històrica d'aquesta paraula... És un mitjà per donar lloc a nous enraonars, per desvetllar i incitar al diàleg... amb les exigències que comporta la pretensió de racionalitat i els límits d'una activitat que és un procés i encara no una possessió plena de l'espai racional.»

«El mantenimiento arcaico de la h sugiere la riqueza semántica y la carga histórica de esta palabra... Es un medio para dar lugar a nuevos enraonars, para despertar e incitar al diálogo... con las exigencias que comporta la pretensión de racionalidad y los límites de una actividad que es un proceso y todavía no una posesión plena del espacio racional.»

"Maintaining the archaic ' $h$ ' in EnRAhONAR hints at the rich semantics and history of this word... It is a way of providing a space for new ways of reasoning, for evoking and initiating dialogue... with the requirements that the aim of rationality brings with it, and the limits of an activity that is a process, rather than the complete possession of rational responses."

Josep Calsamiglia, «Presentació», Enrahonar 1 (1981), 3.

ENRAHONAR, com el mot català «enra(h)onar», reivindica alhora el diàleg i la raó.

ENRAHONAR, como la palabra catalana enra(h)onar, reivindica a la vez el diálogo y la razón.

EnRAHONAR, like the Catalan word 'enra(h)onar', aims to propose both dialogue and reason.

ENRAHONAR en una revista académica internacional de filosofía fundada en 1981 y editada por la Universitat Autònoma de Barcelona (Departamento de Filosofía). Enrahonar pone un especial énfasis en las contribuciones relativas a la razón o racionalidad teórica y práctica en todos sus aspectos y en las distintas disciplinas filosóficas, como la epistemología, la ética, la estética, la metafísica, la filosofía de la ciencia o la filosofía del lenguaje, de la mente y de la acción, incluyendo también la perspectiva histórica. Un tema preferente de investigación es la filosofía catalana. La aceptación de artículos se rige por el sistema de censores (double blind peer review), con evaluadores externos. ENRAHONAR también publica notas bibliográficas y reseñas e invita a presentar propuestas de números monográficos. ENRAHONAR tiene una periodicidad semestral (marzo y octubre). Todos los artículos, notas y reseñas se pueden consultar y descargar gratuitamente. Las normas del proceso de revisión y las instrucciones para los autores se pueden consultar en: http://revistes.uab.cat/enrahonar/about

ENRAHONAR is an international journal of philosophy founded in 1981 and published by the Universitat Autònoma de Barcelona (Department of Philosophy). The journal places emphasis on contributions concerning theoretical and practical reason or rationality in all of their aspects and across all philosophical disciplines, such as epistemology, ethics, aesthetics, metaphysics, philosophy of science, and philosophy of language, mind, and action, as well as historical perspectives, with special attention given to Catalan philosophy. Contributions are accepted following a double-blind peer review process with external reviewers. ENRAHONAR also publishes book reviews and bibliographical notes, and invites guest-edited special issues. EnRAHONAR is published twice a year in March and October. All articles, notes, and reviews can be accessed and downloaded for free. For author guidelines and details on the reviewing process, please visit: http://revistes.uab.cat/enrahonar/about 


\section{Sumari}

Enrahonar. Quaderns de Filosofia

Núm. 53, p. 1-151, 2014

ISSN 0211-402X (paper), ISSN 2014-881X (digital)

Les paraules clau són en llenguatge lliure

http://revistes.uab.cat/enrahonar

\section{Ètica i política del paisatge}

$5 \quad$ Nota editorial

Enrahonar, 2014, núm. 53, p. 5.

7-12 Velayos Castelo, Carmen (Universidad de Salamanca)

Presentación. Ética y política del paisaje. Enrahonar, 2014, núm. 53, p. 7-12.

\section{Articles}

\section{5-28 Veríssimo Serrão, Adriana (Universidade de Lisboa)}

Paisagem e ambiente: uma distinção conceptual. Enrahonar, 2014, núm. 53, p. 15-28.

Neste artigo, mostramos como o conceito de ambiente, quando tomado como categoria principal de uma visão do mundo que procura reconhecer, apreciar e proteger os espaços naturais, conduz inevitavelmente a consequências contraditórias: por um lado, desvaloriza o papel de cada particular, subsumindo-o em conjuntos e totalidades; por outro, contrapõe de modo rígido o humano e o não-humano como duas esferas separadas. Pelo contrário, uma visão do mundo fundada na Paisagem, uma categoria sintética que integra o fundamento natural com dimensões humanas permitirá reatar harmonias e modos de encontro num mundo marcado por profundas cisões e preocupantes sinais de desagregação do humano. $\mathrm{O}$ artigo discute algumas das principais teorias actuais, como as de Allen Carlson e Arnold Berleant, no âmbito da estética ambiental, e de Rosario Assunto, o principal representante da estética da paisagem.

Palavras-chave: paisagem; ambiente; natureza; estética; habitar humano. 


\section{9-42 Espinosa Rubio, Luciano (Universidad de Salamanca)}

Una antropología filosófica del paisaje. Enrahonar, 2014, núm. 53, p. 29-42.

El ensayo ofrece algunas perspectivas filosóficas de la antropología del paisaje, y eso significa incluir tres aspectos de su influencia en la vida humana: $a$ ) el sentido biográfico; $b$ ) las relaciones inherentes entre naturaleza e historia, y $c$ ) el significado ontológico y vital que tiene en nuestra conducta. Por último, es interesante ver el paisaje - por estas mismas razones - como una especie de contrapeso a la virtualización creciente de lo real.

Palabras clave: paisaje; vida; naturaleza; historia; realidad.

\section{3-61 Aragón Rebollo, Toni (Universidad de Salamanca)}

Reconfiguración del paisaje desde lo común.Una perspectiva éticoestética. Enrahonar, 2014, núm. 53, p. 43-61.

El objetivo de este artículo es reflexionar sobre las posibilidades del paisaje como herramienta para construir el espacio desde lo común. Para ello, discutiré la polisemia del paisaje y sus implicaciones en el vínculo entre paisaje y comunidad. Esta reflexión me llevará a criticar los efectos de la hegemonía del sentimiento de lo bello y lo sublime y la visión identitaria existente en nuestra sociedad consumista, así como sus implicaciones en los procesos de participación sobre el paisaje. Como alternativa, expondré las ventajas de una percepción poiética que derivan de una concepción del paisaje como acción dentro de. Se trata de un modo de relacionar el paisaje y la comunidad que contribuye a un modo de habitar y transformar el territorio bajo una concepción de comunidad basada en la communitas de Esposito y en los aportes de la ética del cuidado y del ecofeminismo.

Palabras clave: paisaje; comunidad; percepción poiética; identidad territorial; participación.

\section{3-75 Garrido Peña, Francisco (Universidad de Jaén)}

Topofilia, paisaje y sostenibilidad del territorio. Enrahonar, 2014, núm. 53, p. 63-75.

En este trabajo, realizamos un análisis de las funciones evolutivas que tiene el amor al territorio y al paisaje (topofilia). Estas funciones son, básicamente, dos: fijar la población al territorio y establecer relaciones de solidaridad con las generaciones futuras y la comunidad biótica. Entendemos la topofilia como un instrumento biocultural de adaptación de nuestra especie. Las emociones estéticas y morales que el paisaje provoca son de mucha utilidad para la construcción de una economía moral ecológica. A este uso ecológico y reflexivo del amor al territorio, le llamamos topofilia, que puede ser útil para evitar el despotismo generacional en las decisiones democráticas.

Palabras clave: paisaje; territorio; sostenibilidad; ecología; topofilia; evolución. 


\section{7-91 Arribas Herguedas, Fernando (Universidad Rey Juan Carlos)} Ecología, estética de la naturaleza y paisajes humanizados. Enrahonar 2014, núm. 53, p. 77-91.

El denominado modelo natural ambiental de Allen Carlson sostiene que el valor estético de la naturaleza disminuye a medida que se acrecienta la intensidad de las intervenciones humanas en el entorno. Asimismo, Carlson argumenta que es necesario profundizar en el conocimiento científico de los objetos o de los paisajes para lograr una apreciación estética "correcta» de la naturaleza. Sin embargo, estas premisas no son tenidas en cuenta a la hora de establecer principios para una adecuada apreciación estética de entornos humanizados tales como los paisajes agrícolas, lo que resta coherencia al modelo natural ambiental. En el presente artículo, se examina esta contradicción y se esboza una concepción pluralista de la apreciación estética de la naturaleza que trata de congeniar criterios científicos, éticos y estéticos.

Palabras clave: ecología; estética; paisaje; modelo natural ambiental; Allen Carlson.

\section{3-114 Gümplová, Petra (Institut für Politikwissenschaft)}

Restraining permanent sovereignty over natural resources. Enrahonar, 2014, núm. 53, p. 93-114.

The paper examines the international law principle of the permanent sovereignty over natural resources from a critical perspective of its conflict with demands for global environmental protection and sustainability. It is argued that state framed resource sovereignty per se does not represent an obstacle in the path of greater global environmental justice. The principle is strongly justified as a distinct economic expression of post-war state sovereignty and the ramification of the universalization of such principles as decolonization, self-determination, territorial rights, and sovereign equality of states. It is instead the interpretation of sovereignty and the set of practices established in the name of permanent sovereignty over natural resources that undermine international environmental law - the extension of sovereign resource rights beyond state borders, the continuous priority of unrestricted resource rights and development rights over international standards for environmental protection and sustainable use of resources, and the failure to reinforce notions and principles, both conceptually and legally, that better correspond to the global nature and comprehensive demands of ecological systems. The paper argues that the plausibility of resource sovereignty depends on the interpretation of the concept of sovereignty and how it incorporates self-limiting standards in its exercise. A parallel is established between limiting resource sovereignty using environmental sustainability standards and ecological stewardship and human rights as a widely accepted constraint on the exercise of state power over the population.

Keywords: sovereignty; resources; international environmental law; human rights. 
115-125 Lladó Mas, Bernat (Grup d'art geogràfic (Sa)badall)

Globalització, art, geografia. Enrahonar, 2014, núm. 53, p. 115-125.

Avui en dia, les metàfores geogràfiques i cartogràfiques són molt presents en el món de l'art. Utilitzar eines i recursos propis de la geografia, especialment el llenguatge cartogràfic, és molt comú en certes pràctiques i discursos artístics contemporanis. Amb tot, han estat pocs els esforços a l'hora d'intentar comprendre i interpretar aquesta situació. En aquest sentit, l'expressió crisi de la raó cartogràfica, elaborada pel geògraf Franco Farinelli, ens hi pot ajudar. Descriurem l'arc que va des del naixement de la raó cartogràfica fins a la crisi actual que pateix. Això ajudarà a entendre l'emergència de l'art cartogràfic. En citarem alguns exemples i els interpretarem tenint en compte el que hem exposat.

Paraules clau: art geogràfic; raó cartogràfica; Franco Farinelli; globalització; crisi de representació.

\section{Ressenyes}

127-130 Veríssimo Serrão, Adriana. Filosofia da Paisagem: Uma Antologia (Maria José Varandas).

131-133 Veríssimo Serrão, Adriana (coord.). Filosofia e Arquitectura da Paisagem: Um Manual (Carlos Javier Ferrero Martínez).

134-138 Nogué, Joan; Puigbert, Laura; Bretcha, Gemma i Losantos, Àgata (eds.). Reptes en la cartografia del paisatge: Dinàmiques territorials $i$ valors intangibles (Bernat Lladó Mas).

139-142 García Gómez-Heras, José María. Bioética y ecología: Los valores de la naturaleza como norma moral (Fabiola Leyton).

143-145 García Gómez-Heras, José María. Debate en bioética: Identidad del paciente y praxis médica (Mónica Delgado Carreira).

146-149 Pérez-Borbujo, Fernando (ed.). Ironía y destino: La filosofía secreta de Søren Kierkegaard (Roger Mas Soler).

151 Llibres rebuts 


\section{Nota editorial}

Segurament al lector atent d'EnRAhONAR no li van passar per alt uns petits canvis que vam introduir en el número anterior: la indicació de les dates de recepció i d'acceptació de cada article i l'ús del digital object identifier (DOI). A partir d'aquest volum, un subtítol en anglès, An International Journal of Theoretical and Practical Reason, acompanya el títol i el subtítol en català: Enrahonar. Quaderns de Filosofia. Per tal de facilitar la comprensió de la paraula "Enrahonar» als lectors que no saben la nostra llengua, hem afegit a la part interior de la coberta del darrere unes breus explicacions. Esperem que aquests canvis — que en realitat formen part d'un procés ja iniciat fa molt de temps-, juntament amb l'enfortiment dels diversos consells de la revista i la gestió integral amb el programa Open Journal Systems (OJS), ens ajudin a mantenir, i si és possible augmentar, la qualitat de la revista i a projectar-la ben enllà de les nostres fronteres.

EL DIRECTOR 



\title{
Presentación
}

Ética y política del paisaje

\author{
Carmen Velayos Castelo \\ Universidad de Salamanca \\ cvelayos@usal.es
}

Cuando nacemos, lo hacemos en el seno de un territorio que no elegimos, pero que seguramente marcará nuestra existencia, como lo harán los diversos lugares que habitemos a lo largo de nuestra vida. Dicho territorio pareciera ser un Faktum más o menos inamovible y «dado" que nos condiciona, pero sobre el que la filosofía no ha reflexionado con asiduidad. Y, desde luego, cuando lo ha hecho, el asunto de la elección y recreación de los espacios híbridos en los que vivimos ha constituido un asunto filosófico sin repercusiones aparentemente éticas, más bien ligado a la creatividad, al gusto o a la estética (cuando no al espacio a menudo vetado de los derechos de propiedad o de soberanía nacional). Lo que hiciéramos, pues, con el paisaje no parecía muy vinculado a la libertad ética y política, al bien, a la justicia o a la felicidad individual y colectiva.

Pero sabemos perfectamente que, para bien y para mal, el paisaje no está designado sin más y que su variación cuenta con innumerables implicaciones de justicia y felicidad para los que lo habitan. Ya lo anunció Víctor Hugo: «La filosofía se ha ocupado muy poco del hombre fuera del hombre, y no ha examinado más que superficialmente y casi con una sonrisa de desdén las relaciones del hombre con las cosas y con la bestia, que a sus ojos no es más que una cosa. Pero, ¿̇no hay aquí abismos para el pensador? [...] Existe en las relaciones del hombre con las bestias, con las flores, con los objetos de la creación, toda una gran moral todavía apenas vislumbrada, pero que acabará abriéndose paso y que será el corolario y el complemento de la moral humana» (Hugo, 2000: 118-119; citado en Calderón Quindós, 2004: 11).

Esto resulta interesante, siendo como es la libertad uno de los grandes temas de la filosofía de todos los tiempos, pero que pocas veces ha sido abordado en relación con el paisaje: ¿por qué elegimos o eligen por nosotros tal o cual entorno público, ciudad deshumanizada o sostenible, jardín con flores o centro comercial, hectáreas de praderas en el margen de carreteras transitadas y plagadas de agrotóxicos? ¿Qué posibilidades tiene el individuo de intervenir en los bienes comunes, como la biodiversidad, y con qué consecuencias? 
La situación ecológica planetaria es ya alarmante y —a buen segurovamos a empezar a sentir, novedosamente, el reproche moral de las generaciones ya nacidas y futuras por lo que no hicimos para impedir la barbarie que se avecina en nuestro entorno. Los paisajes no son necesarios sino contingentes $\mathrm{y}$, como fruto de nuestra libertad, podemos estar siendo negligentes hasta el punto de generar espacios degradados difíciles de ser vividos. ¿No es éste un tema eminentemente filosófico?

Vivimos un momento de tránsito en este sentido. La legislación, la política y la ética no pueden dejar ya de abordar el problema de nuestra interferencia con el medio natural, y no sólo social. Nuestro planeta está interconectado y los riesgos no tienen fronteras. La degradación ecológica afecta ya a todos los sistemas de la Tierra y estamos cerca del colapso energético y climático. El paisaje, con toda su carga de significación cultural (véase el artículo en este número de Adriana Veríssimo sobre el concepto), no es ya algo éticamente inocente; no es tampoco un mero escenario para las acciones del ser humano y que puede ser transformado sin complejos. En la actualidad, asistimos al redescubrimiento — entre amargo y melancólico — del paisaje sostenible que no querríamos perder para siempre, pero también a la progresiva lejanía respecto a la tierra y a la espectacularización de algunos parajes naturales (véase al respecto el artículo en el número que presento de Antonio Aragón Rebollo) que no compensan la generalizada depredación de los ecosistemas terrestres ni la terrible falta de equidad en el uso colectivo de sus servicios.

En definitiva, y desde hace al menos cincuenta años, está en crisis la forma convencional (salvo excepciones) que la filosofía occidental tuvo de pensar la naturaleza desde un punto de vista práctico: el de la justificación sin apenas límites de su utilización como fuente de progresos para el ser humano. La naturaleza nos pertenece. Famosas son las exhortaciones francesas (Descartes), inglesas (Bacon) y otras respecto al dominio de la naturaleza en el siglo XVII. La modernidad exacerbó la visión de la naturaleza nutricia como un soporte de bienes y servicios, si bien con voces divergentes y melancólicas que surgirían a doquier. Y, desde luego, no es que antes hubiera faltado el afán de derrochar y abusar del medio, pero varios factores lo habían limitado. En primer lugar, la naturaleza siempre se sintió más cercana y cómplice de lo humano en las cosmovisiones premodernas - que aún la entendían como organismo-, que en las perspectivas mecanicistas del mundo que se afianzaron a comienzos de la edad moderna. Valga decir, sin embargo, que no parece que las visiones del mundo sean la única fuente de normatividad (directa o indirectamente). Si no, resulta difícil de entender, por ejemplo, que, en el siglo XI, se devastaran 3.944 árboles (un bosque entero) para la construcción del castillo de Windsor (Gimpel, 1981: 67-70), si no es ya porque la visión orgánica del mundo no era suficiente para justificar el respeto, o no lo suficientemente robusta en sí misma en ese tiempo y lugar; o porque, además, los intereses a corto plazo fueran demasiado compactos, mientras que los de mantener el bosque aparecieran lamentablemente difusos, amén de que no se tuviera conciencia de la posibilidad de llegar a generar una crisis ecológica global más que meramente parcial. 
Lastimosamente, hubo muchas sociedades - como la de la isla de Pascua o la de los anasazi en Estados Unidos (Diamond, 2005) — que no supieron entender la estrecha relación de dependencia que sus habitantes mantenían con los árboles y con el resto de la naturaleza. Y desaparecieron, como lo haremos nosotros si no cambiamos de rumbo rápidamente.

La modernidad puso aún peor las cosas. Y no vino sola con una comprensión de la naturaleza como algo objetivo y sin valor. La historia concreta de las sociedades modernas y contemporáneas trajo consigo un proceso progresivo de separación de la misma, a través de una concentración cada vez mayor de la población en las ciudades y de una sucesiva desacralización de la naturaleza hasta que fue convertida en soporte, objeto e instrumento. Vino - en su versión científica - a reforzar una imagen distorsionada de la totalidad natural a través de una ciencia tendente a comprender el mundo fragmentariamente y al ser humano como un ser independiente de los demás y de su entorno.

Pero, como destaca Francisco Garrido Peña en su artículo de este número de ENRAHONAR, el antídoto para la alienación respecto al paisaje es la topofilia como «sentido de lugar». El paisaje, entonces, es el tópos emocional de la sostenibilidad que supone la funcionalidad evolutiva y ecológica de la topofilia y la conservación del paisaje como estímulo de solidaridad intergeneracional.

El paisaje, nos recuerda el autor, es un conjunto de símbolos bioculturales que identifican y singularizan un territorio social y ecológicamente determinado. Amamos el paisaje, no porque sea el mejor, sino porque es el nuestro. El capitalismo ha fomentado la concentración de la población y la disolución de los lazos colectivos, comenzando con la ruptura emocional con el paisaje propio. Necesitamos, argumenta Garrido Peña, la reterritorialización de la vida social, de la política, de la economía; recuperar el sentido de pertenencia a un lugar por medio de experiencias comunes; abandonar una topofilia capitalista y antagónica.

Desde luego, uno no puede amar los no lugares (Augé, 1998), carentes de carácter simbólico o relacional. Tampoco podemos conciliar una vida alienada (desvinculada de las demás vidas y para la que nuestros cuerpos orgánicos y dependientes no están preparados) con el lujo de la experiencia ocasional de naturaleza como si de un objeto de consumo se tratase.

«La cuestión (además de rehumanizar estos entornos) —afirma Luciano Espinosa en su trabajo en este número- es evitar esta situación de indiferencia hacia el paisaje natural, considerado como un gigantesco no lugar, irrelevante y anónimo». Y recuerda a Ortega cuando afirma: «Los paisajes me han creado la mitad mejor de mi alma».

Una buena parte de los escritos de este número recuperan las emociones y la experiencia estética como fuente de conservación de la vida natural y social; por ejemplo: Fernando Arribas nos advierte de la ligazón experiencial entre paisaje y ser humano y de la desaparición de algo interno a nosotros a medida que se produce la desaparición de la naturaleza. ¿Podría incluso decrecer o desparecer eso que llamamos «humanidad» junto a la desaparición de los chopos?, se pregunta con Bryan Barry. Pero, como también advierte Antonio Ara- 
gón en su escrito, es importante paisajear, asumir la póiesis común del paisaje sin acudir a visiones esencialistas: «En definitiva — afirma — la identidad con el territorio es muy importante, pero no es ni necesaria, ni garantía suficiente para la conservación de un paisaje [...] No cabe duda de que la belleza singular es uno de los valores más cotizados cuando se habla de paisaje. Sin embargo, esta tendencia social e individual creciente a consumir la belleza según cánones pintoresquistas, junto con la promoción de la identificación esencialista entre habitante y territorio en los paisajes proximales que acabo de señalar, han traído como consecuencia el aumento del desapego de muchas otras personas con el paisaje distal en el que vive».

Por eso, merece nuestra atención una segunda perspectiva de la ética del paisaje. Me refiero a la conservación del paisaje en un sentido planetario general. ¿Podemos entender a la Tierra en su conjunto como paisaje? Me viene a la memoria que las pinturas holandesas de paisaje del siglo Xvir se llamaban "países». Obviamente, nos falta un sentimiento generalizado de pertenencia hacia la Madre Tierra y, lo que es peor, un sentido colectivo de copertenencia y de complicidad con ella y con el resto de los congéneres. Nadie sale a la calle con ira e indignación a reclamar medidas contra el cambio climático, ni éste crea, por el momento, sentimientos colectivos de pérdida, de traición. Bajo esta dimensión global y urgente del problema, porque afecta a nuestra vida y a la de nuestros descendientes, no es tan fácil que surjan sentimientos ni arraigos cósmicos, porque quizás nos falte una historia común de nuestra identidad en la Tierra; una historia, en suma, en la que nos sintamos reconocidos. ¿Cómo abrigar como nuestro lo que no conocemos, ya sea el Ártico o una llanura desértica y lejana? ¿Cómo contribuir y cooperar con aquellos que están lejos y a los que ni siquiera reconocemos? Aún más, ¿`cómo puede recuperar la política con mayúsculas y vinculada a gobiernos nacionales, las relaciones proactivas que surgen del contacto concreto con la tierra y con los cercanos (microrrelaciones) y que harían posible - por analogía - la cooperación internacional necesaria (macrorrelaciones) para detener la degradación de los bienes comunes de esta Tierra?

Pero, evidentemente, y ante problemas tan acuciantes como el cambio climático, la pérdida de biodiversidad y otros, quizás no baste con destacar el aspecto amable de la cooperación tal y como se da en poblaciones pequeñas. Lo cierto es que la cuestión ambiental que acecha al frágil ecosistema global de la Tierra requiere cooperación internacional, pero lo único con que contamos hasta ahora es una evidente tragedia de los comunes (Hardin, 1968), donde cada país (y, en suma, cada individuo, cada empresa, cada unidad de acción y consumo) evita reducir su contaminación y uso de energía - como sería necesario-- persiguiendo intereses a corto plazo. El resultado, a pesar de que el final lógico de esta competitividad es bien conocido en un mundo finito, es fatal para todos.

Obviamente, tenemos razones suficientes para tratar de evitar esta tragedia: desde el egoísmo, y sin necesidad de apelar a ningún tipo de simpatía, ni siquiera de arraigo. Sabemos con claridad y certeza que debemos cooperar para 
conseguir evitar el colapso. El problema es que la reciprocidad necesaria tampoco parece tener éxito (yo hago, tú haces) más que en sociedades pequeñas y autocontroladas. Como ejemplificó perfectamente la premio nobel Eleanor Ostrom (2011), la huerta valenciana, compuesta por unas 16.000 hectáreas regadas por ocho canales del Turia, ha logrado sobrevivir en un lugar semiárido gracias a la estricta cooperación entre los huertanos. A cada huerta le corresponde una cantidad de agua del canal proporcional a su tamaño. El Tribunal de las Aguas se reúne desde hace siglos durante las mañanas del jueves fuera de la puerta de los Apóstoles de la catedral de Valencia. No necesitan abogados, pero sí que todos tengan roles definidos y acuerden reglas estrictas, como dar prioridad a los cultivos que necesitan más agua en épocas de intensa sequía.

En definitiva, los propios campesinos se han autorregulado creando convenciones eficientes. Eso sí, para Ostrom, esta cooperación recíproca tiene unas características claras:

— Las normas que rigen el uso de los bienes comunes están bien adaptadas a las necesidades y a las condiciones locales.

- La mayoría de las personas afectadas por estas reglas pueden participar en la modificación de las reglas.

- Se reconocen los derechos de los miembros de la comunidad a diseñar sus propias reglas y, a su vez, estos derechos son respetados por las autoridades externas.

- Existe un sistema de vigilancia del comportamiento de los miembros y, a su vez, los miembros de la comunidad en sí pueden llevar a cabo esta vigilancia.

- Existe un sistema gradual de sanciones.

- Los miembros de la comunidad tienen acceso a mecanismos de bajo costo en lo referente a la resolución de conflictos.

La cuestión ahora es si este modelo de cooperación recíproca (homo reciprocans) podría ser extrapolable a nivel global. La historia de las sucesivas reuniones posteriores a Kyoto para llegar a un acuerdo sobre mitigación y adaptación al cambio climático parece indicar que es muy difícil. Nos faltan instituciones democráticas globales y la participación real de la sociedad civil afectada. Pero sólo un acuerdo internacional consensuado desde abajo podrá paliar el incremento de daños a nuestro paisaje común. Contamos con poco tiempo. Por eso, Petra Gümplova se plantea, en su trabajo en este número de ENRAHONAR, la necesidad de politizar esa cooperación y de revisar la soberanía nacional sobre el paisaje. Defiende que la plausibilidad de la soberanía sobre los recursos depende de la interpretación del concepto de soberanía y de la manera como se incorporen normas autolimitadoras en el ejercicio de la misma. No todo vale porque haya sido hecho dentro de nuestras fronteras.

Para finalizar, este número sobre ética y política del paisaje que he tenido el gusto de coordinar pretende combinar una mirada micro con una mirada macro de la protección del paisaje. Como el relato El hombre que plantaba 
árboles, de Jean Giono (2000), existen posibilidades glocales de intervenir positivamente sobre la naturaleza común, pero también se requieren intervenciones políticas de amplio alcance que limiten las actuaciones antiecológicas globales bajo el supuesto de una responsabilidad compartida y diferenciada, además de criterios estrictos de justicia intergeneracional.

\section{Referencias bibliográficas}

Augé, M. (1998). Los no lugares. Espacios del anonimato: Una antropología de la sobremodernidad. Barcelona: Gedisa.

Calderón Quindós, F. (2004). El bosque rousseauniano: belleza y dignidad moral: Jean Jacques Rousseau y la dimensión inter-especifica de los problemas ambientales. Tesis doctoral. Recuperado de la Librería Virtual Cervantes.

Diamond, J. (2005). Colapso: Por qué unas sociedades perduran y otras desaparecen. Barcelona: Debate.

Gimpel, J. (1981). La revolución industrial en la Edad Media. Madrid: Taurus.

Giono, J. (2000). El hombre que plantaba árboles. Palma de Mallorca: Olañeta.

Hardin, G. (1968). «The Tragedy of the Commons». Science [en línea], 162, 1243-1248. <http://dx.doi.org/10.1126/science.162.3859.1243>

Hugo, V. (2000). Los Pirineos. Traducción de Victoria Argimón. Palma de Mallorca: Olañeta.

Ostrom, E. (2011). El Gobierno de los bienes comunes: La evolución de las instituciones de acción colectiva. México DF: Universidad Nacional Autónoma de México / Fondo de Cultura Económica. 
ARTICLES 



\title{
Paisagem e ambiente: uma distinção conceptual*
}

\author{
Adriana Veríssimo Serrão \\ Universidade de Lisboa \\ adrianaserrao@fl.ul.pt
}

Recibido: 22-12-2013

Aceitado: 13-3-2014

\section{Resumo}

Neste artigo, mostramos como o conceito de ambiente, quando tomado como categoria principal de uma visão do mundo que procura reconhecer, apreciar e proteger os espaços naturais, conduz inevitavelmente a consequências contraditórias: por um lado, desvaloriza o papel de cada particular, subsumindo-o em conjuntos e totalidades; por outro, contrapõe de modo rígido o humano e o não-humano como duas esferas separadas. Pelo contrário, uma visão do mundo fundada na Paisagem, uma categoria sintética que integra o fundamento natural com dimensōes humanas permitirá reatar harmonias e modos de encontro num mundo marcado por profundas cisões e preocupantes sinais de desagregação do humano. $\mathrm{O}$ artigo discute algumas das principais teorias actuais, como as de Allen Carlson e Arnold Berleant, no âmbito da estética ambiental, e de Rosario Assunto, o principal representante da estética da paisagem.

Palavras-chave: paisagem; ambiente; natureza; estética; habitar humano.

\section{Abstract. Landscape and Environment: a conceptual distinction}

In this article, I aim to show how the concept of environment inevitably leads to contradictory consequences when it is taken as a major category of a worldview that seeks to recognize, appreciate and protect natural spaces: on the one hand, it devalues the role of each particular element, subsuming it into sets and wholes; on the other, it rigidly opposes the human and the non-human as two separate spheres. On the contrary, a world view founded on the category of Landscape, a synthetic category which involves a natural foundation with human dimensions, allows resuming harmonies and modes of living in a world marked by profound divisions and worrying signs of disintegration of the human.

Keywords: landscape; environment; nature; aesthetics; human living.

* O artigo reproduz, com alterações, o capítulo «Ambiente e Paisagem: Categorias em confronto", do livro Filosofia da Paisagem: Estudos, 2013, Lisboa, Centro de Filosofia da Universidade de Lisboa, p. 103-116, e resulta de uma investigação conduzida no âmbito do projecto Filosofia e Arquitectura da Paisagem, Centro de Filosofia da Universidade de Lisboa, 2010-2013. 


\section{Sumário \\ Introdução 3. Paisagem, o ponto de encontro do Homem com a Natureza \\ 1. Ambivalência do conceito de ambiente \\ 2. Ambiente e Paisagem: \\ Referências que conciliação possível?}

\section{Introdução}

\section{À Carmen Velayos}

A opção, presente em muitas orientações actuais, de subsumir o conceito de Paisagem no de Ambiente tem dado origem a uma série de malentendidos, com implicações na edificação de uma estética e de uma ética em contexto natural que procuram apreciar e proteger os espaços naturais. Tratase de uma opção que evita, acima de tudo, enfrentar com profundidade a própria ideia de Natureza, fundadora de uma visão integral do mundo, reduzindoa a um conjunto de dimensões físicobiológicas e/ou ecológicas e agravando, paradoxalmente, a separação artificial entre nãohumano e humano, que procura precisamente superar. Grandemente simplificada, a estética é privada da sua matriz mais genuína de expressão da sensibilidade a favor da postulação da objectividade do Belo, cujo reconhecimento deve basearse em conhecimentos de tipo científico. Também em termos éticos a noção global de Ambiente é imprecisa, justamente pela impossibilidade de conter a diversidade e a singularidade das manifestações naturais nas situações concretas em que somos chamados a agir.

Uma vez libertas da tradicional associação à vista, ao cenário e ao panorama, o entendimento das paisagens como unidades integradas e espaços do habitar permitirá conciliar o fundamento natural com dimensões constitutivamente humanas, como a História e a Cultura, e responderá mais facilmente a problemas candentes do tempo presente e futuro, desde o desenho das cidades até à invenção de formas de viver alternativas.

\section{Ambivalência do conceito de ambiente}

$\mathrm{O}$ uso, tão disseminado na actualidade, do substantivo ambiente e do adjectivo ambiental para designar o conjunto de orientaçōes em ética, estética e política que consideram o ser humano não mais como ser exclusivo, mas como membro e participante de uma comunidade de entidades naturais, é gerador de ambiguidade, já que os termos remetem, pelo menos, para dois sentidos:

a) Numa acepção corrente e ampla, ambiente refere tudo o que nos rodeia e envolve a nossa existência, cobrindo níveis tão diferenciados desde ambientes naturais a artificiais, desde ambientes mistos a ambientes pessoais e sociais 
(«ambiente popular», «ambiente aristocrático»...), sendo por isso usado em aplicações e associações metafóricas significando ar, atmosfera, clima ( (o bom ambiente desta sala»).

b) Numa acepção técnicocientífica restrita, designa mais especificamente o meio ambiente, desde o ar que respiramos ao conjunto das condições biofísicas (solo, clima, etc.) da vida orgânica e da permanência da vida sobre a Terra. Frequente é a associação (ou identificação) com ecossistema ou com habitat, termo oriundo, por sua vez, da ecologia (ciência dos meios de vida, que estuda a relação dos organismos vivos com os respectivos ambientes naturais), criada por Ernst Haeckel, em 1866, como subdisciplina da biologia.

A palavra ambiente procede do latim ambiens, ambientis, e do verbo ambire, 'rodear', 'estar de ambos os lados'. Logo, a expressão meio ambiente (Umwelt, Environment) introduz uma precisão, mas acaba por resultar num pleonasmo ao duplicar a ideia de envolvência.

Não é apenas na linguagem corrente que os dois sentidos se cruzam. A imprecisão entre os níveis persiste no interior da estética ambiental, dando origem a posiçôes divergentes.

\subsection{O conceito "ecológico» de ambiente}

Segundo Allen Carlson, a principal razão de ser desta orientação prendese com o contributo que pode dar ao ambientalismo (environmentalism): «a experiência estética da natureza foi e continua a ser de vital importância para a conservação e preservação do ambiente natural» (Carlson, 2009: 1). E justifica, seguindo Eugene Hargrove, com a função que a consciência estética tem desempenhado na formação de decisões que preservaram «alguns dos mais magníficos ambientes da América do Norte» (Hargrove, 1979). Em abono da estreita correlação entre estética ambiental e ambientalismo, Carlson cita ainda autores de referência que têm contribuído para instituir as bases e os objectivos desta consciência. Segundo J. Baird Callicott: «Que tipos de território (country) consideramos serem excepcionalmente belos faz uma enorme diferença quando temos de decidir que lugares salvar, quais restaurar ou realçar, ou quais destinar a outros usos. Por isso, uma estética natural sólida é crucial para uma sólida política de conservação e gestão do território» (Callicott, 2008: 106). No mesmo sentido, para Ned Hettinger (2005: 76): «a ética ambiental beneficiaria em tomar a estética ambiental mais a sério».

Os propósitos não podiam ser mais claros: a estética ambiental não é uma reflexão autónoma da filosofia solicitada por uma problemática bem definida, mas um conjunto de princípios gerais que presta apoio à ética da conservação (ou da preservação), em matéria de decisão ambiental e ordenamento do território. É já relevante que em causa esteja a demarcação do que há, ou deve ser especialmente considerado, pressupondo implicitamente que algo haverá que não tem necessariamente de o ser: «decidir que lugares salvar, quais restaurar ou realçar, ou quais destinar a outros usos». 
Procuremos perceber como se estabelece esta articulação, ou melhor, que critérios seguros poderá dar esta estética para decidir a escala de valores entre lugares da natureza. Depois de considerar o que chama de «estética da natureza tradicional», reduzida globalmente aos tópicos negativos da tradição pitoresca e da tradição formalista, Carlson enuncia as suas deficiências: o antropocentrismo; a obsessão com o cenário; a superficialidade e trivialidade; a subjectividade; a vacuidade moral. Em abono da assumpção da estética ambiental como uma estética nova, superadora das deficiências de que enformaria essa tradição, são apresentadas em contraposição esquemática as características que articulariam a apreciação estética com as obrigações morais, ou a beleza com o dever:

1. O acentrismo: uma apreciação adequada exige que o apreciador (appreciator) se desligue do seu ponto de vista para emitir um ajuizamento que não seja nem particular nem antropocêntrico.

2. O foco no ambiente: mesmo que seja difícil praticar sempre o acentrismo, que toma a natureza como um todo, o recipiente (recipient) não deve aterse a aspectos particulares, mas considerar, se não o todo completo, pelo menos os conjuntos em que os elementos particulares se integram.

3. A seriedade: uma experiência dirigida para o que a natureza realmente é e para as qualidades que actualmente tem, sustentando «uma espécie de respeito pela verdade» do objecto, independente do agrado e outras tonalidades afectivas do sujeito.

4. A objectividade: a formação de consensos apreciativos, que na senda da noção de padrão defendida por David Hume em Of the Standard of Taste podem fundar (tal como na avaliação da arte) princípios normativos de uma estética crítica, a cargo dos true judges, os críticos que sabem e podem avaliar.

5. O comprometimento (engagement) moral: uma experiência livre do que diz respeito aos interesses de um apreciador particular, que supera o esteticismo e, ao articular estética e ética, prepara para a acção correcta.

Passemos por alto a ligeireza com que é esboçada a imagem da estética tradicional, bem como o uso do termo experiência, dificilmente conciliável com a relação entre um apreciador (ou recipiente), despersonalizado e desfocado em que se dá a passagem directa do conhecimento certo ao bem agir. Não se pode em rigor afirmar que, para Carlson, o papel do sujeito individual seja anulado, como sucede nos movimentos da ecologia profunda, mas é certo que a atitude que lhe é pedida acaba por limitarse a um mero suplemento de adesão para aqueles ambientes naturais previamente reconhecidos no seu valor intrínseco pelos críticos informados e experientes, que, numa simplificada leitura de David Hume, orientariam o gosto dos outros. Fixemonos no significado de ambiente: conjuntos naturais que subsumem os elementos particulares, os quais são relevantes apenas pelo lugar ou função ocupado num sistema:

[...] o foco da apreciação estética [da natureza] tem de ser ampliado para incluir cada um e todos os tipos de ambientes. Tem de ser focadono ambiente (envi- 
ronmentfocused) em vez de estar ligado a tipos particulares de ambiente e/ou a tipos particulares de características de ambientes. (Carlson, 2009: 11)

A conversão entre ambiente e natureza, como se de sinónimos se tratasse, evita que a filosofia ambiental se sinta obrigada a esclarecer o próprio conceito de natureza, que permanece indeterminado, incólume à complexa evolução histórica, nas fronteiras de uma metafísica nunca assumida e prudentemente evitada. Ao mesmo tempo holista e impreciso, reduzido ao conjunto de dimensões físicobiológicas e/ou ecológicas, não remete para uma ideia global de natureza - o ambiente não é uma componente da natureza, mas é a natureza mesma enquanto natureza selvagem - e cuja tipologia e categorização objectiva cabe aos cientistas determinar. $\mathrm{O}$ ambiente (natural), por sua vez, subsume em si todos os entes individuais.

A ausência de reflexão sobre o conceito de natureza, uma lacuna que acarreta uma demissão da vocação fundamentadora da filosofia e o abandono das bases da estética à ciência da natureza e à história natural, deixa nas mãos dos especialistas a responsabilidade da decisão política quanto aos lugares excepcionalmente belos a conservar, num cruzamento de cientismo e gestão do património, com o risco da eleição de maravilhas naturais e a consequente despromoção dos lugares ambientalmente pobres, monótonos ou desinteressantes. Não será difícil contestar que não só a pretensa objectividade da ciência é altamente falível, como o facto de a ciência da natureza não estar isenta da marca de interesse humano antropocentrado, tantas vezes mais ao serviço da economia e menos da estética. A confusão de antropocentrismo e humanismo tem sido observada por vários autores, entre os quais Yuriko Saito, que mostrou bem como as grelhas de compreensão da ciência são humanas, e que os seus resultados têm sido frequentemente armas de domínio, e não de acesso directo à realidade (Saito, 1998).

Igualmente frágil é o entendimento do significado da beleza. Se a beleza não é atributo de cada elemento, mas é condicionada pela função exercida no sistema mais amplo, a imprecisão permanece total quanto à escala desse sistema, sendo que a própria noção de ecossistema é hierárquica e depende da interacção das comunidades e da sua integração em sucessivos níveis de complexidade. Se por estética se entende aqui uma visão do mundo fundada no modo directo da observação, mesmo que acompanhada de conhecimentos, não se percebe como poderia Carlson escapar à tão criticada visualidade, já que a apreensão dos sistemas estaria determinada por aquilo que a vista alcança. Mas esta estética está bem mais próxima de uma calologia que acaba por tornar redundante o apelo à individualidade do apreciador. $\mathrm{O}$ primado do todo sobre a parte prova a evidente opção antiindividualista em matéria de ética ambiental e a afinidade com a Land Ethic, nas referências privilegiadas a Leopold e Callicot, bem como algum distanciamento avisado quanto ao acentrismo holista de Godlovitch, que defende o mistério da natureza para lá do sentimento e do conhecimento (Godlovitch, 1994). 


\subsection{O ambiente como espaço de habitação}

Embora esta acepção restritiva de ambiente presida a muitas posições nãoantropocêntricas da filosofia, como sinónimo de enquadramento natural e, em última instância, de natureza selvagem (wilderness), ela está longe de obter unanimidade. Outro pensador relevante da Environmental Aesthetics, Arnold Berleant usa o termo numa escala inclusiva das acepções $a$ ) e $b$ ) acima referidas, muito próximo do sentido originário de oikos ('casa'). Nos termos em que o define, é clara a recusa da natureza intocada e a inserção da cultura e sociedade na modelação do natural. Os ambientes são vividos através das modalidades — gostos, gestos, memória- de cada cultura e modelados por constantes actos e respostas; são físicoculturais e sociais.

Sendo o ambiente tanto o que envolve o homem quanto os lugares em que este habita — decorrente da matriz arquitectónica que Berleant substitui à pictórica一, não é a alternativa mas a reciprocidade que pode fundar tanto a estética como a ética. Enquanto a posição ultraobjectiva de Carlson, que ao procurar vencer o antropocentrismo, instaura um insanável dualismo entre o humano e o natural/ambiental como duas esferas independentes e contrapostas pela inimizade, a estética da continuidade — defendida por Berleant como nova episteme - ao dispor o humano em situação, acolhe também o outro lado do problema: o ambiente não designa só o que nos envolve (exteriormente), mas também o que nos penetra e modela (interiormente):

O ambiente é mais do que simplesmente a nossa envolvência externa. Nós compreendemos com uma força cada vez maior que a vida humana está intimamente ligada às condiçôes ambientais e que não há linhas divisórias nítidas que nos separem do ambiente em que habitamos. À medida que respiramos o ar à nossa volta com todos os seus poluentes e o percebemos na nossa corrente sanguínea, ele tornase parte dos nossos corpos. Isto também acontece com a comida que ingerimos, com todos os pulverizadores e aditivos. Até mesmo as roupas que usamos no "lado de fora» do nosso corpo fazem parte da nossa imagem corporal e as nossas casas são a maior de todas as peças de vestuário, expressando as nossas personalidades e os nossos valores. Esta relação é de reciprocidade, uma vez que cultivamos a comida que comemos e moldamos as roupas que vestimos e as casas em que vivemos. (Berleant, 1977: 11)

Integração e reversibilidade são princípios fortes que fundam uma visão compreensiva, mas também uma ética valorativa consciente de que o homem faz os ambientes que, por sua vez, também o fazem. Livre da ficção de uma natureza pura, a interpenetração do natural, do natural humanizado e do sóciocultural permite mostrar também como os diversos ambientes —incluindo as cidades - influenciam, positiva ou negativamente, com acento favorável ou adverso, a naturalidade do humano enquanto corporalidade e sensorialidade, através dos nossos movimentos e acções.

Confrontando os pressupostos de ambas as doutrinas, não é difícil mostrar como são óbvias as diferenças: 


\begin{tabular}{|l|l|}
\hline $\begin{array}{l}\text { Ambiente «ecológico» } \\
\text { A. Carlson }\end{array}$ & $\begin{array}{l}\text { Ambiente como «casa» } \\
\text { A. Berleant }\end{array}$ \\
\hline $\begin{array}{l}\text { Holismo vago não especificado nos seus } \\
\text { diferentes níveis, mas sempre natural. }\end{array}$ & $\begin{array}{l}\text { Permite a distinção de níveis particu- } \\
\text { larizados e a diversidade dos ambien- } \\
\text { tes. }\end{array}$ \\
\hline $\begin{array}{l}\text { Obriga à demarcação entre natureza } \\
\text { intocada e natureza intervencionada. }\end{array}$ & $\begin{array}{l}\text { Aceita todo e qualquer enquadra- } \\
\text { mento de vida, seja natural, misto ou } \\
\text { cultural. }\end{array}$ \\
\hline $\begin{array}{l}\text { Um naturalismo rígido: o ambiente } \\
\text { (natureza) como exterioridade em rela- } \\
\text { ção ao humano. }\end{array}$ & $\begin{array}{l}\text { Interdependência do natural e do hu- } \\
\text { mano. }\end{array}$ \\
\hline $\begin{array}{l}\text { Objectividade e unilateralidade: o apre- } \\
\text { ciador julga, sem ser afectado. }\end{array}$ & $\begin{array}{l}\text { Reciprocidade e reversibilidade: o } \\
\text { participante é afectado pelo que } \\
\text { experiencia. }\end{array}$ \\
\hline
\end{tabular}

Subjacente a esta oposição, aquela que opõe conhecimento e sensibilidade, encontramse duas antropologias: uma que reduz o humano ao conhecimento, ultravaloriza o saber e apela à mente que decide; a outra, que parte do sentir perceptivo e cinestésico de um sujeito concreto para a compreensão da diversidade qualitativa desses espaços em que o corpo (do homem total, individual e social) se move. A estética do comprometimento constitui facilmente a base crítica de uma ética e de uma pedagogia ambiental, com a vantagem de não separar natureza e cidade, isto é, de não reduzir a exigência ética ao natural extraurbano, certamente um dos pontos mais frágeis e polémicos da chamada estética positiva.

No artigo acima citado (Carlson, 2009: 19), em que não só defende os seus pontos de vista como procede a uma recapitulação crítica das principais orientaçóes da estética ambiental, Carlson vai mesmo ao ponto de aplicar os cinco tópicos do esquema para classificar os aspectos fortes e fracos os principais modelos em confronto - radicalizados em cognitivos e nãocognitivos (emocionalistas), o que faz transparecer a contraposição rígida entre conhecimento e emoção, o que lhe permite comparar a respectiva validade, de que resulta:

\begin{tabular}{|l|l|l|}
\cline { 2 - 3 } \multicolumn{1}{c|}{} & \multicolumn{1}{c|}{$\begin{array}{c}\text { Aproximaç̧ões } \\
\text { cognitivas }\end{array}$} & \multicolumn{1}{c|}{$\begin{array}{c}\text { Aproximações } \\
\text { nãocognitivas }\end{array}$} \\
\hline Acêntrica & Forte & Muito forte \\
\hline Focadano ambiente & Forte & Muito forte \\
\hline Séria & Forte & Não claro \\
\hline Objectiva & Muito forte & Fraco \\
\hline Moralmente comprometida & Não claro & Fraco \\
\hline
\end{tabular}


Assim expostas, as duas acepções de ambiente —ambiente biofísico e ambiente-lugar de habitação- são diametralmente opostas ponto por ponto. No entanto, para Berleant, usando embora o termo paisagem para referir a experiência de uma localização particular, a categoria primária é ainda a de ambiente, uma opção longamente justificada, por considerar que paisagem remete preferencialmentepara as belas vistas eos belos lugares celebrados por artistas (Berleant, 1997: 12-13; 2012: 347).

\section{Ambiente e Paisagem: que conciliação possível?}

Apesar de o conceito de Natureza como unidade do mundo continuar a ser usado por muitos pensadores actuais, diversos motivos justificam a adopção de uma outra categoria susceptível de unificar questôes de estética e de ética no contexto da situação de crise do fundamento. A ideia de Natureza - como todo coeso e fundamento da existência (nãohumana e humana), durante milénios o sustentáculo de todas as cosmovisōes - tornouse um conceito problemático. Por um lado, por hipostasiar uma totalidade inacessível e/ou remeter para uma ordem e estabilidade há muito passadas; por outro, não menos relevante, pela impossibilidade actual de distinguir o natural do artificial. Esta incerteza talvez explique o uso indiscriminado do adjectivo natural, que resulta pelo exagero e trivialidade numa simples palavra vazia e por isso, em última instância, ineficaz.

Sendo que o pensamento tem por função a escolha das categorias com vista a ordenar a realidade, a respectiva hierarquia não é indiferente. A alternativa a Ambiente, susceptível da mesma hipostasiação atribuível a Natureza, encontrase no conceito de Paisagem, cuja fecundidade foi reconhecida, desde os anos 70 do século xx pelo filósofo italiano Rosario Assunto, que a retirou da esfera das representaçôes e imagens para a colocar na ordem do ser, elevandoa assim a categoria central da filosofia estética. Antes de qualquer representação do mundo, a paisagem é um lugar do mundo onde a natureza se torna objecto de uma experiência estética integral.

Uma das reflexōes mais precisas encontrase no pequeno ensaio Paisagem, ambiente, território, que trata de desfazer a confusão dos três termos, com evidentes prejuízos quer na compreensão dos problemas, quer em actos de gestão dos solos ou administração dos territórios:

Creio que neste ponto surgirá com bastante facilidade uma definição de "paisagem» como "forma» que o ambiente («função» ou "conteúdo» [...]) confere ao território como «matéria» de que ele se serve. Ou melhor, se quisermos ser mais precisos, "paisagem» é a "forma» na qual se exprime a unidade sintética a priori (no sentido kantiano: não a "unificação» de dados recebidos separadamente, mas a «unidade» necessária que condiciona o seu apresentarse na consciência) da "matéria (território)» e do "conteúdooufunção (ambiente)». [...] $\mathrm{O}$ ambiente concreto, o ambiente que vivemos e do qual vivemos vivendo nele, é sempre o ambiente como forma de um território: paisagem. (Assunto, 1976: 45-48, in Serrão, 2011: 128-129) 
Paisagem é uma unidade sintética na qual se dá a ligação entre território e ambiente: este ambiente concreto; mais precisamente, uma forma a priori, termo que Assunto empresta de Kant para referir a condição de possibilidade de X: seja da experiência, enquanto receptividade ao mundo («o seu apresentarse na consciência»), seja da existência mesma («do qual vivemos vivendo nele»). $\mathrm{O}$ mundo nunca se dá como território ou como ambiente, mas sempre na unidade de matéria e forma: esta paisagem determinada. É unidade de ser e experiência.

Para alcançar todas as implicações da formulação aqui tão condensada seria necessário percorrer de fio a pavio o livro Il paesaggio e l'estetica, de 1973, onde a teoria da paisagem como modo de ser (da natureza) encontra a sua fundamentação plena. Importa somente, para a questão em debate, salientar que Assunto distingue os dois conceitos, mas não os coloca como alternativos. A distinção consolida a posição da filosofia estética contra o cientismo; porque a estética é da ordem do sensível, uma experiência do ambiente — na acepção científica- como envolvência global é qualquer coisa de incompreensível. O ambiente não é enquanto tal experienciável, é apenas concebível. Mas, por outro lado, porque a experiência estética tem na origem o sentimento vital proporcionado pelas qualidades reais de cada paisagem onde estamos, Assunto defende, contra o intelectualismo que confina a apreciação ao plano reflexivo, mental, que as condições da vida biofísica, favoráveis ou desfavoráveis, afectam as sensaçôes de bemestar ou malestar provocadas pelos elementos. Na base da reflexão está a fisicidade das sensações.

A ontologia assuntiana pode sem contradição articular estética e ecologia, visto que a contemplação tem por base a simbiose de vida com vida, o sentir positivo ou negativo, a satisfação ou a não satisfação, como Assunto atesta num texto claríssimo:

O ponto de vista estético interessase pela paisagem, enquanto a paisagem é, podemos já dizêlo, o ambiente da ecologia considerado como objecto de contemplação: e no deleite (como na frustração, no sofrimento) que acompanha a contemplação, está também contido, contemplado, por sua vez, em conjunto com o ambiente promovido a paisagem, o bemestar (ou o malestar) que aquele mesmo ambiente nos faz experimentar em relação à satisfação ou não satisfação das nossas necessidades vitais; e o ponto de vista ecológico, por seu turno, interessase, podemos dizêlo, pela mesma paisagem de que cuida o ponto de vista estético: sendo que o ambiente da ecologia outra coisa não é do que a paisagem de que falamos em estética como um objecto de contemplação, mas considerado do ponto de vista da acção que as suas várias componentes exercem sobre a formação e conservação da vida. (Assunto, 2005: 136)

Assunto vinca bem a especificidade respectiva dos métodos da estética, que tem por base uma metafísica da natureza vital, e da ciência do ambiente, que complementarmente se cruzam, mas não se confundem.

Não foi apenas a filosofia pura a evidenciar a distinção e proximidade destes pontos de vista. Encontramola em algumas ciências descritivas, por exem- 
plo, no sentido que, da perspectiva da geografia, lhe empresta Jean Demangeot. Considerando a ambiguidade do termo meio, ao mesmo tempo centro e periferia, extrai daí a reversibilidade entre meio e envolvência, que ora coloca o meio no centro, como objecto de estudo, ora o homem no meio, como um ponto central que faz parte dele. Paisagem resolve precisamente esta duplicidade mediante a alternância entre base invisível e expressão visível:

O meio (milieu) é etimologicamente o que se encontra no centro do espaço. Em seguida, a palavra acabou por designar a noção inversa, isto é, o que o envolve, o que banha o centro: o peixe vive no elemento marinho. É neste sentido que o geógrafo o emprega, subentendendo geralmente que é o homem que ocupa o centro do «meio geográfico». Este «meio» dizse natural quando nele predominam os elementos não ou pouco transformados pelo homem: rochedos, árvores ou pântanos. Já não é natural quando nele predominam os artefactos: imóveis, máquinas, aeroportos, etc. A paisagem é a expressão visivel, ao mesmo tempo que o sustentáculo, do meio. (Demangeot, 1994: 582)

Idêntica posição de convergência subjaz ao pensamento mesológico de Augustin Berque. A mesologia, como teoria dos meios (milieux), procura transpor a alternativa entre cientismo e humanismo, ou objectivismo e subjectivismo, que atravessa a época moderna e chega sob múltiplas formas até aos dias de hoje. O seu ponto de partida é sintético: a interacção entre homem e meio através do corpo medial, uma relação dupla, porque se exerce nos dois sentidos e resulta precisamente das dinâmicas do cruzamento, do movimento trajectivo:

É uma trajecção, ou seja, um movimento no qual o mundo subjectivo e o mundo objectivo não deixam de interagir, por assim dizer, em espiral, produzindo deste modo uma realidade trajectiva (semisubjectiva, semiobjectiva), que é própria dos nossos meios. (Berque, 1993, in Serrão, 2011: 193-194)

Berque critica o erro das abordagens naturalistas e ecológicas, com a diluição da paisagem no ambiente, e a unilateralidade do homem como ser físico, esquecendo o plano de significações que mediatizam a nossa relação com o exterior enquanto seres de significaçôes. A sua noção de cultura como elaboração simbólica não renega a base objectiva e natural; o homem mediatiza o meio vivente (Umgebung), a biosfera, em mundo humano, reelaborando constantemente os dados imediatos, culturalizandoos, sem abandonar a natureza. O plano que resulta da trajecção entre espaço e tempo, entre meio e história, é precisamente o da paisagem em cuja compreensão se funda o pensamento paisageiro:

Concebo a mediância como o sentido ao mesmo tempo subjectivo e objectivo (uma significação, uma sensação, uma tendência), da relação de uma sociedade com a extensão terrestre (relação que é um meio). Este sentido conjuga três níveis: o do emsi das coisas e da natureza (a extensão do mundo físico ou objectivo); o das relaçôes ecológicas que ligam a espécie humana ao seu ambiente; e o da paisagem, onde actuam as relações de ordem simbólica, pelas quais uma cultura funda em natureza a subjectividade colectiva. Esta conjugação cum- 
prese simultaneamente no espaço (o meio) e no tempo (a história). (Berque, 1993, in Serrão, 2011: 193)

Se a mesologia de Augustin Berque é predominantemente culturalista, visto que a paisagem corresponde ao estrato de maior complexidade, vejamos um exemplo de pendor naturalista, para sublinhar ainda que a relação entre paisagem e ecologia não tem de ser excludente. Uma ética da paisagem terá, segundo o artista e jardineiro LouisGuillaume Le Roy, em conta a sua estrutura ecológica,a temporalidade dos seus processos intrínsecos, profunda, mas que se dá sempre no presente:

Jardins e paisagens evoluem no tempo. - Os agentes (vegetais, animais, homens) de todos os ecossistemas que determinam em conjunto a paisagem devem contribuir especificamente para a formação desta paisagem. - Estes agentes devem contribuir para a formação contínua das paisagens. - A paisagem é o resultado de uma actividade que evolui como um todo num ecossistema. - A concepção de um sistema ecológico é impossível. O homem aceitará num sistema ecológico uma certa situação como estando dada. Pelo seu trabalho, contribuirá para a evolução do sistema ecológico em questão. [...] - O trabalho humano deve ter como fim conservar a diversidade dos ecossistemas, enriquecêlos ou reinstaurálos porque a diversidade deles é a condição de base para uma evolução sã e equilibrada da paisagem. (Le Roy, 1997, in Le Dantec, 1996: 456-457)

\section{Paisagem, o ponto de encontro do Homem com a Natureza}

A filosofia europeia entronca nas grandes construções sistemáticas da filosofia da natureza elaboradas entre Iluminismo e Romantismo, para as quais remete em última instância o pensamento da paisagem. $\mathrm{O}$ cruzamento de natureza e cultura longamente sedimentada pela pintura e literatura, ou pela arte dos jardins, não considera problemática a reunião de Natureza, Cultura e História, que encontram precisamente na paisagem um momento concordante. Pode acentuar um ou o outro dos pólos, consoante as correntes mais naturalistas ou mais culturalistas, pode celebrar as manifestaçóes sublimes e selvagens ou a modelação humana dos lugares, mas não se detém na ficção de um estado de natureza intocado.

Já o ambientalismo tem de sobrevalorar o meio, ficando muitas vezes por esclarecer se esse meio ecossistémico inclui também os humanos ou se se restringe aos nãohumanos. A subtracção do humano aos ambientes que avalia e dos quais independe é reforçada pela posição moralista quanto ao homem, por tendência agente mau que deve proteger a natureza boa. A idealização da natureza virgem assume, por vezes, contornos de sacralização de monumentos da terra prometida em que entronca a identidade nacional americana.

A filosofia da paisagem, por seu turno, parte da polaridade, o que justifica a centralidade cada vez maior que desempenha nas recentes éticas e estéticas da natureza: 
- É uma categoria compósita: admite múltiplas intersecções entre natureza e cultura, desde que a base natural esteja presente.

- É uma categoria ôntica: tem vindo a perder a restrição à visualidade e aos sentidos de cenário e de espectáculo raro, próprios do paradigma artístico — pictórico, teatral e literário- da Modernidade, para se apresentar como peculiar região do ser.

- É uma categoria plástica, uma síntese inobjectivável e irredutível (a Natureza e a Ambiente) que se desdobra em pequenas unidadestotalidades: os lugares singulares, não precisando incorrer nos intermináveis debates de individualismo e holismo da ética ambiental.

Não deixa de ser significativa a expansão do pensamento paisageiro para orientaçóes que não partiam inicialmente dele, e que talvez devido ao divórcio de culturas têm olhado com desconfiança para a tradição do pictórico e do cenográfico pretensamente dominantes na cultura europeia. Fala por si a recuperação por parte de alguma cultura ambientalista americana, à margem da influente estética positiva, objectivista e cientista.

Exemplificamos esta significativa alteração de paradigma com um estudo de Kiyokazu Nishimura sobre a descoberta do sentido da paisagem, que se apoia na reflexão de T. J. Diffey (1993) e Frank Sibley (2001). Importa, para o tema deste artigo, incidir nos pontos essenciais: a defesa da componente subjectiva e o papel das sensações. O que trazem as sensações? Sobretudo a capacidade de diferenciação no todo compacto que é o ambiente. O autor mostra como sensações mais voláteis — olfacto e paladar - não são desestruturadas e informes, por oposição à forma do conceito. É por via da sensibilidade que a variedade das coisas se apreende e que os ambientes podem ser discriminados. Esta capacidade de acolhimento é precisamente oferecida pela paisagem:

[...] encontrandonos ainda no ambiente com um enquadramento (framing) particular baseado no conceito de ambiente natural como "paisagem», organizamos os materiais crus dos nossos cinco sentidos numa certa ordem particular e apreciamola, à paisagem, como "estética». Neste sentido, "paisagem» pode ser considerada como uma das categorias estéticas que estabelecemos sob a restrição de tempos e culturas como um quadro (frame) para "paisagem", que originalmente significou apenas uma secção geográfica de natureza. Para apreciar o ambiente natural esteticamente é preciso enquadrálo e considerálo sob a categoria "paisagem». (Nishimura, 2011: 40)

Chegamos por fim àquele que é talvez o núcleo irredutível: a paisagem não é a natureza (em si) nem o humano (para si), mas o ponto de encontro de homem e natureza. A natureza que se encontra é esta paisagem, e o homem este indivíduo. Todos os debates sobre objectivismo e subjectivismo perdem validade quando partimos do encontro. Ela é simultaneamente região ôntica —se acentuarmos o ladoobjecto- e abertura ao ser (natureza) se acentuarmos a ontologia do humano. 


\section{Referências bibliográficas}

Assunto, R. (1976). «Paesaggio, Ambiente, Territorio: Un tentativo di precisazione concettuale». Bollettino del Centro Internazionale di Studi di Architettura Andrea Palladio, 18. Tradução em português: SERRÃo (2011), 128129.

Assunto, R. (2005). Il paesaggio e l'estetica. 2a edição. Palermo: Edizioni Novecento.

Berleant, A. (1997). Living in the Landscape: Towards an Aesthetics of Environment. Lawrence: University Press of Kansas.

- (2012). «O significado mutável da paisagem». Em: Serrão (2012), 347 s.

Berque, A. (1993). «L'écoumène, mesure terrestre de l'homme, mesure humaine de la Terre: Pour une problématique du monde ambiant». L'Espace Géographique, 4, 299305. Tradução em português: SERRÃo (2011).

Callicott, J. B. (2008). "Leopold's Land Aesthetic». Em: Carlson, A. e Lintott, S. (eds.). Nature, Aesthetics, and Environmentalism. Nova Iorque: Columbia University Press.

Carlson, A. (2009). "Contemporary Environmental Aesthetics and the Requirements of Environmentalism». Aesthetics, JTLA, Journal of the Faculty of Letters. The University of Tokyo, 34.

Demangeot, J. (1994). Les Milieux «naturels» du globe. Paris/Milan/Barcelone: Masson.

Diffey, T. J. (1993). «Natural Beauty without Metaphysics». Em: Kemal, S. e Gaskell, I. (eds.). Landscape, Natural Beauty and the Arts. Cambridge: Cambridge University Press.

Godlovitch, S. (1994). «Icebreakers: Environmentalism and Natural Aesthetics». Reimpr. em: Carlson, A. e Berleant, A. (eds.). The Aesthetics of Natural Environments. Peterborough: Broadview Press, 2004.

Hargrove, E. (1979). «The Historical Foundations of American Environmental Attitudes». Environmental Ethics [em linha], 1, 209-240. $<$ http://dx.doi.org/10.5840/enviroethics19791314>

Hettinger, N. (2005). «Allen Carlson's Environmental Aesthetics and the Protection of the Environment». Environmental Ethics [em linha], 27. $<$ http://dx.doi.org/10.5840/enviroethics200527141>

Le Dantec, J.-P. (1996). Jardins et Paysages: Une Anthologie. Paris: Éditions de la Villette.

Le Roy, L.G. (1977). «Principes écologiques qui devraient régir jardins et paysages». Em: Le DanteC, J.-P. (1996), Jardins et Paysages: Une Anthologie. Paris: Éditions de la Villette, 456-457.

Nishimura, K. (2011). "The Aesthetics of Smell and Taste for the Appreciation of Landscape». JTLA, Journal of the Faculty of Letters. The University of Tokyo, 36.

Saito, Y. (1998). "Appreciating Nature on Its Own Terms». Environmental Ethics [em linha], 20, 2. <http://dx.doi.org/10.5840/enviroethics199820228> 
Serrão, A. V. (coord.) (2011). Filosofia da Paisagem: Uma Antologia. Lisboa: Centro de Filosofia da Universidade de Lisboa.

- (coord.) (2012). Filosofia e Arquitectura da Paisagem: Um Manual. Lisboa: Centro de Filosofia da Universidade de Lisboa.

Sibley, F. (2001). «Taste, Smells, and Aesthetics». Em: Sibley, F.; Benson, J.;

Redfern, B e Cox, J. R. (eds.). Approach to Aesthetics: Collected Papers on Philosophical Aesthetics. Oxford: Clarendon Press.

Adriana Veríssimo Serrão é professora associada de Filosofia na Faculdade de Letras da Universidade de Lisboa. Tem dedicado a sua investigação à Estética e à Antropologia Filosófica, e, mais recentemente, à Filosofia da Natureza e da Paisagem. Coordena o projecto de investigação Filosofia e Arquitectura da Paisagem no Centro de Filosofia da Universidade de Lisboa.

Adriana Veríssimo Serrão is Associate Professor in Philosophy in the Faculty of Letters o the University of Lisbon. His research has focused on Aesthetics and Philosophical Anthropology, and, more recently, on the Philosophy of Nature and Landscape. She coordinates the research project Philosophy of Architecture and Landscape at the Center for Philosophy of the University of Lisbon. 


\title{
Una antropología filosófica del paisaje
}

\author{
Luciano Espinosa Rubio
}

Universidad de Salamanca

espinosa@usal.es

Fecha de recepción: 11-12-2013

Fecha de aceptación: 21-1-2014

\section{Resumen}

El ensayo ofrece algunas perspectivas filosóficas de la antropología del paisaje, y eso significa incluir tres aspectos de su influencia en la vida humana: a) el sentido biográfico; b) las relaciones inherentes entre naturaleza e historia, y $c$ ) el significado ontológico y vital que tiene en nuestra conducta. Por último, es interesante ver el paisaje — por estas mismas razones - como una especie de contrapeso a la virtualización creciente de lo real.

Palabras clave: paisaje; vida; naturaleza; historia; realidad.

\section{Abstract. A Philosophical Anthropology of landscape}

The paper gives some philosophical perspectives on the anthropology of landscape. This means including three aspects of its influence in the human life: $a$ ) the biographical sense, $b$ ) the inherent relations between nature and history and $c$ ) the ontological and vital meaning that it has in our behaviour. It is interesting, lastly, to see the landscape — for the same reasons - as a kind of counterbalance for the increasing virtualization of the real.

Keywords: landscape; life; nature; history; reality.

\section{Sumario}

\section{Presentación 4. Lo vital: la carne común del mundo}

2. Lo existencial: paisaje con figuras Para terminar

3. Lo cultural: naturaleza e historia Referencias bibliográficas 


\section{Presentación}

Resulta muy adecuado interpretar el paisaje como lugar de encuentro (literal y figurado) o cruce de caminos que permite establecer múltiples niveles de lectura, según muestra este volumen. Dentro del enfoque antropológico, es mucho más conocido el estudio sociocultural o empírico del mismo (la interacción del hombre y su medio vertida en tipos de vida - los registros etnográficos- que vinculan territorios con habitáculos, medios de subsistencia, instrumentos, códigos, etc.), mientras que el estudio propiamente filosófico parece más teórico e incluso ajeno al paisaje, que, por definición, está fuera del ser humano. Sin embargo, vamos a intentar realizar el segundo acercamiento en términos a la par sintéticos y transversales, por lo que se harán referencias a distintos aspectos del tema sin elegir uno en particular, dado que la vida los incluye a todos. No se trata de acumular elementos sin más ni de generar categorías huecas, sino de ofrecer un destilado o un mínimo común denominador que ayude a entender mejor la entraña misma del ser humano en diálogo con el paisaje.

La filosofía carga con la cruz de ser generalista y difusa, especulativa en el mal sentido de la palabra, aunque permite, a cambio, realizar una mirada de conjunto basada en la posibilidad de relacionar ámbitos, según el propósito clásico de abordar lo común. En el terreno antropológico elegido, eso significa combinar lo existencial y biográfico (primer epígrafe) con la cultura del paisaje que vincula naturaleza e historia (apartado segundo), hasta desembocar en una tercera vertiente ontológica de la vida que lo engloba todo. Dicho de otra manera, hay que partir de sujetos concretos que habitan y modifican paisajes, haciéndolos suyos de diversas maneras, interiorizándolos, lo que sólo puede entenderse dentro del marco de referencia más amplio de la objetivación colectiva, es decir, en forma de exteriorizaciones perdurables a lo largo del tiempo; para terminar con una visión comprehensiva que nace de lo que podría llamarse la carne del mundo, el sostén donde el adentro y el afuera se funden en la praxis. Terminaré con una reflexión final que aglutine esos aspectos en una nueva dirección. Veamos, pues, a qué paisaje conceptual nos llevan estas sendas.

\section{Lo existencial: paisaje con figuras}

Recuérdese que, al paisaje ${ }^{1}$, lo completa el paisanaje, que el lugar reclama en su desnudez al sujeto que lo inviste de sentido, y por eso también se habla de un "paisaje humano» correlativo e inmerso en el otro. Ambos se imbrican de tal modo que son inseparables y recíprocos, como es obvio, aún antes de entrar en consideraciones etnológicas. Quiere decirse que las dimensiones geográfica, topográfica, biológica y estética que le son propias cobran el carácter unificado que denominamos paisaje sólo para quienes captan el todo simbólico, más allá

1. Lo entendemos aquí como natural y urbano, aunque se pone el acento en el primer tipo. 
de las especializaciones fragmentadas de los animales que viven en un mundo circundante específico (Umwelt, según la antropología germana clásica). De ahí que los seres humanos escapen a los estímulos parciales y sean los únicos que habitan un territorio, es decir, los que lo otean desde la atalaya de la vida inteligente y sentimental para concertar variables y apropiarse mentalmente de él en alguna medida. Es la paradójica experiencia de estar dentro y fuera del entorno a la vez.

Así, por otro lado, se llega al punto de tener la conciencia de pertenecer a un hogar cuyo rostro visible es el paisaje, lo cual desborda los límites físicos de la propia casa o del propio terreno, hasta sentirse instalados en un conjunto - sea rural o urbano- que aglutina rasgos convergentes (orografía, clima, otros seres, vías de comunicación, agua, objetos manufacturados, arquitectura, colores..., y afectos), finalmente vividos de manera integrada en el día a día. Claro que esta experiencia básica se olvida con frecuencia, más aún dentro de los ambientes hipertecnificados, donde es habitual utilizar otra clase de expresiones tales como «ocupar y ordenar» el territorio, según resume la jerga administrativa al uso. Si se prefiere otro aspecto no menos ilustrativo, podríamos interpretar el gran invento del GPS (sin menoscabo de su utilidad) como epítome de la abstracción tecnológica que es signo de los tiempos, en tanto que permite abarcar el espacio en el que nos movemos a la vez que vaciarlo de contenido. Por el contrario, aquí se propone un uso antropológico ampliado (no utilitario ni esquemático) del vocablo paisaje, multívoco en sus relaciones con distintos registros.

2.1. La raíz ontológica de todos ellos es que los individuos sólo se reconocen a sí mismos como tales en relación con un contexto o con un escenario - que incluye a los demás sujetos-, cuya primera semblanza figurativa es un paisaje. Dicho de manera más concreta, toman conciencia adulta de existir - esto es, adoptan una perspectiva determinada que es única- en el seno de un marco de referencia físico, convertido, a su vez, en fachada visible de todo un mundo simbólico, donde la etimología de mundus remite al surco que, según los antiguos romanos, delimita el espacio habitado por el hombre. Esta es una de las vías primarias para conformar una identidad, de modo que construirse a sí mismo consiste en el proceso inicial de interacción física y simbólica con esa placenta ambiental más o menos acogedora que ya se da por supuesta y de la que apenas se es consciente. En resumen, venir al mundo es ingresar en un gran metapaisaje que incluye territorios, personas, otros seres vivos y cosas, sólo relativamente acotado por una cultura y que cada cual recorre poco a poco, al menos por las siguientes tres vías de acceso.

Bajo un punto de vista sincrónico, todos obedecemos a las premisas que implican un ensamblaje de paisajes naturales y humanos (la separación nítida de ambos tipos es imposible y tiene bastante de retórica, como es obvio, al igual que la que distingue lo natural del artificio, dado que sólo los humanos definen y ponen nombres). A partir de ahí, comienza a tejerse la experiencia propia de cada sujeto en relación con los lugares que habita, lo que se condensa en una 
memoria personal (dentro de la común) que permite afirmar cierta autonomía subjetiva. Lo curioso es que uno se diferencia de aquellos paisajes físicos y simbólicos que le sostienen de entrada cuando traza su propio perfil gracias a (en contra de) lo que recibe: toda figura encaja a la par que contrasta respecto a un trasfondo. Dicho de otro modo, la dependencia y la independencia que siempre definen a una persona también son recíprocas en esto, de modo que, al cabo, todos somos interdependientes, y tal hecho sucede, además, en referencia a un hábitat. Semejante vínculo puede leerse también en un sentido ecológico lato que Edgar Morin ha llamado principio ecosistémico de la complejidad (Morin, 1984: 172 s.): la autonomía de cualquier individuo se alimenta del entorno, según el doble vínculo de que el sí mismo responde con estabilidad homeostática a las fluctuaciones externas y, al revés, un medio demasiado estático obliga al individuo a introducir cambios, de modo que se trata de un diálogo sin fin.

Nada más fácil que ver una segunda dimensión del asunto, esta vez evolutiva. Basta pensar en la historia filogenética de la especie, cuyo origen pronto se asocia a las peculiares características del paisaje primigenio que fue la sabana del África nororiental, por más que haya habido luego migraciones y muchos otros entornos y factores concurrentes en la hominización (anatómicos y sociales, adaptativos y creadores, etc.). Por otro lado, desde un enfoque ontogenético, la psicología evolutiva indica que la maduración del bebé requiere de impresiones afectivas y sensoriales que permiten el desarrollo de sus capacidades, primero psicomotrices y después intelectivas (según la célebre descripción de Piaget), estéticas y morales más tarde. El espacio y el tiempo, en fin, se articulan sin solución de continuidad mediante contenidos crecientemente simbolizados, ya sea para el homo que se hace sapiens o para el niño que crece y aprende. Lo decisivo en nuestro caso es que ambos procesos contienen una suerte de memoria ambiental constituida por aquellos nexos perceptivos del adentro y el afuera (un entorno físico y unas habilidades para desenvolverse en él), memoria asociada al resto de tipos intervinientes (la memoria genética de la especie, la cultural, la biográfica de cada uno, etc.), de manera que todo ello confiere estructura y densidad a la vida. Nadie habita en el vacío, claro está, y eso que denominamos ambiente — como el entorno para el desarrollo- requiere tener muy en cuenta al paisaje, por motivos evidentes, aunque a menudo quede olvidado y en un segundo plano.

Tanto más si se añade una tercera dimensión propiamente histórica (la memoria conjunta de lo que se ha hecho y padecido), en virtud de la cual las civilizaciones establecen orígenes comunes y sitúan su cuna en ámbitos determinados, de forma que, a lo largo de su desenvolvimiento, se configuran sus propios paisajes simbólicos; por ejemplo, resumido en pocas claves de distinto signo: la quintaesencia de la cultura egipcia sería la fusión del río Nilo, el desierto, las pirámides y la muerte; o las calzadas y la obra pública que circundaban el Mare Nostrum, expandiendo el comercio y las leyes, lo serían de Roma. Son paisajes tópicos, nunca mejor dicho, constituidos tanto por lugares como por ideas, pero fundido todo en algo intangible que les da sentido uni- 
tario, una fuerza de representación que impregna el imaginario colectivo. El hecho es que, para definir una civilización y sus gentes, no cabe separarlo analíticamente, y que la identidad usa ciertos escenarios e iconos que se convierten en referencia vital.

Tal vez los sujetos lo ignoran en su momento, pero el que mira el conjunto desde las tres perspectivas comentadas sí lo sabe, y ahora aún más, puesto que vivimos en la llamada época de la información y de imágenes omnipresentes. Aparte de eso, cabe decir que la propia individualidad emerge y se entiende hoy dentro de ese entorno tecnológico (junto a su poderosa iconografía) y no paisajístico al modo tradicional, de ahí, por ejemplo, el éxito gigantesco de las nuevas redes sociales. Sin embargo, incluso la reconfiguración perceptiva y simbólica que las mediaciones técnicas implican respecto al paisaje natural acusará las grandes modificaciones ecológicas que se avecinan (cambio climático, etc.), dado que el paisaje simbólico del que hablamos (ese que incluye naturaleza y cultura) es más intrincado de lo que parece a la hora de caracterizar una parcela importante de nuestra autocomprensión. Por otra parte, la ventaja de su carácter mestizo — ser algo dado y construido a la par- es que no cabe referirse como antaño a la influencia determinista de las «aguas, aires y lugares» a la hora de establecer la idiosincrasia de los pueblos y su vida social, económica y política, tal como dictaba el Corpus hipocrático (Glacken, 1996: 105-134), según una creencia transcultural que ha perdurado durante siglos. La clave liberadora está en que el ser humano modifica artificialmente cuanto le rodea por mil vías de acción. Pero dejemos la historia y retornemos a la vivencia concreta, que siempre es común y diferente.

2.2. A partir del conocido mensaje sensorial y cognitivo que nos dejó la teoría de la Gestalt sobre el estrecho lazo entre el fondo y la forma, podría generalizarse que la existencia personal es una figura que se recorta necesariamente contra el telón de un paisaje, despojado a la postre de camuflajes y atrezos, como muestra la literatura (Gala, 1985: 18). Este recurso estético supone que la desnudez de la vida íntima siempre está un poco vestida, pues se pertenece a un lugar cargado de significados (a veces subliminales), lo mismo que este pertenece un poco al sujeto, de manera que uno termina por encontrarse o perderse a sí mismo en alguna clase de paisaje. Las cuestiones pragmáticas o afectivas van juntas, dado que las personas son capaces de pasar de una feroz defensa del territorio (cercana a los animales) a la contemplación desinteresada del mismo, donde los variados sentidos culturales están en viaje de ida y vuelta permanente. Todo ello va calando hasta que el paisaje se convierte casi en una segunda piel, la que duele más cuando se pierde por la distancia o cuando queda herida por la destrucción. De ahí, quizá, que los seres humanos hayan incluido tantas veces a los paisajes en la evocación narrativa de su vida, como si fuera un dato irrenunciable de su destino particular.

La llamada educación sentimental está trufada de emociones e imágenes ligadas al medio, sea por el peso indiscutible del clima o por la configuración específica de un lugar donde siempre se puede descubrir alguna belleza. Parece 
claro que nos llega muy adentro la lluvia o el sol recurrentes, el verdor o la aridez, el mar o el monte..., e incluso el cemento y el cristal, como los compañeros de viaje que siempre están ahí. Los sentidos se acostumbran a una atmósfera particular y poco después les sigue el corazón, sin necesidad de cargar las tintas sentimentales. Por otra parte, surge en cada ambiente un ritmo vital que une lo objetivo y lo subjetivo, ya se trate del frenesí de la gran ciudad o del ciclo más lento de la actividad fuera de ella, sin caricaturizar ninguno de los casos ni caer en juicios de valor apresurados. Quiero decir que hay demasiados tópicos románticos y/o modernizadores alrededor de este asunto, por más que la ansiedad no sea recomendable para nadie. Ciertamente, lo que importa es que, en el universo de cada persona, caben muchos pequeños mundos que, a menudo, se mezclan y se solapan, pero todos tienen un paisaje propio que ella reconoce.

Digamos que existe una gran conexión cronotópica que enlaza tiempos y espacios sucesivamente, un caleidoscopio de ambientes y momentos, lo que bien podría denominarse los paisajes vitales — propicios o no es otra cuestión-, que acogen y presionan a los humanos de distintos modos. Y todo eso deja un poso indeleble, el precipitado experiencial de ciertos reflejos, hábitos, percepciones y valores, aunque no se sabe bien dónde empiezan y acaban tales aspectos ni cuándo se cruzan sus planos. Tampoco es posible deslindar lo afectivo de lo intelectual o lo ético de lo estético, al insertar al yo en el marco de sus paisajes físicos y metafísicos, acaso entrelazados y en movimiento, esta vez entendidos como pasajes de tránsito imprescindibles para nutrir la personalidad a lo largo de la vida. Se trata, en fin, de un bagaje del que nadie puede desprenderse, salvo que se arranque la piel.

Veámoslo gracias al ejemplo paradigmático que proporciona Ortega y Gasset, quien se adentró por estos caminos de la reflexión sobre el paisaje con intensidad, dentro de la conocida referencia al yo y su circunstancia, como el paraguas teórico que permite entender la variante que nos ocupa:

Hay en mi obra bastantes estudios del paisaje. He sentido los campos apasionadamente, he vivido absorto en ellos, sumido en su textura de gran tapiz botánico y telúrico; he amado, he sufrido en ellos. A la verdad, sólo se ven bien los paisajes cuando han sido fondo y escenario para el dramatismo de nuestro corazón. Conforme avanza éste por la vida lleva consigo a la rastra todo el repertorio de sus antiguos paisajes esenciales como un empresario de teatro viaja con sus decoraciones y bastidores. (Ortega y Gasset, 1929: 635)

Se trata de una experiencia integral (de superficie y subterránea), absorbente, que vincula a sujeto y paisaje. En este caso, silvestre y, por tanto, lejos del mundus humano que mencionábamos más arriba. Es una cronotopía (asociaciones espacio-temporales de esta clase, frecuentes a lo largo de la vida del autor) ligada a lo más íntimo, de forma que el paisaje desborda el papel habitual de figurante o simple correlato. La reveladora metáfora del teatro (el «dramatismo" cordial corresponde a un "empresario» y hay un «repertorio» donde coinciden lo afectivo y lo paisajístico) muestra bien cómo toda persona es, al 
cabo, un conjunto de personajes fundamentales y, por tanto, el creador trashumante de su propia empresa vital, desarrollada en algunos escenarios o "paisajes esenciales» que no puede olvidar.

Semejante vivencia del paisaje es mucho más que una mera ocasión para el solaz efímero y pasa a convertirse - tras la salida fuera de los lugares habituales- en el desencadenante de aprendizajes y recogimientos, hasta el punto de que nadie un poco sensible parece inmune a ello. Más allá de los avatares particulares, parece una oportunidad casi universal para establecer el diálogo consigo mismo a través de la mediación del paisaje, convertido en un rodeo fecundo para encontrarse y meditar. Como tantas veces, tomar distancia respecto a lo rutinario permite una mejor perspectiva sobre lo propio, más si la comunicación especular del adentro y el afuera acontece en un marco placentero y sosegado, aunque no convenga reducirlo ni mucho menos al célebre modelo pastoril. Lo que Ortega remacha es la profunda convergencia de lo biográfico con lo filosófico del asunto: el paisaje es uno de los hilos importantes con que se teje la vida, como el tapiz único que incluye lugares, emociones e ideas.

\section{Lo cultural: naturaleza e historia}

Que todo lo humano es cultural a la vez que biológico siempre debe ser tenido en cuenta (Espinosa, 2007a), como el hecho mismo de que la experiencia humana está siempre mediada por innumerables símbolos y sólo hay paisaje para quien lo mira. El territorio existe con independencia del sujeto, claro está, pero eso que denominamos paisaje es una noción sometida a los avatares del devenir categorizador de las sociedades. Ahí se condensa la relación entre naturaleza e historia de modo privilegiado, ya se trate de un paisaje virgen o modificado por la mano del hombre. Es la síntesis biunívoca de lo dado y lo construido, sea por medio de la descripción, los actos transformadores, la representación artística, la narración, etc., combinados en múltiples formas y grados. Digamos que todo paisaje — como muchas otras nocionesresponde a dos polos de un mismo continuo (la sintaxis y la semántica), es decir, una estructura que refleja de manera inteligible lo que aparece ante nosotros y una dotación convencional de significados diversos, como ya sabemos. Lo que ocurre ahora es que vamos a considerar ambos planos a través de ejemplos objetivados en las distintas tradiciones, en cuyo repertorio el sujeto elige.

Se podrá decir que hay momentos en los que la conciencia simbólica parece en suspenso, como si el paisaje se impusiera por sí solo y adquiriera una fuerza autónoma, adueñándose del sujeto a través de la armonía, la admiración o el estupor que es capaz de provocar. En este caso, estaríamos cerca de lo que se ha llamado sublime y que alude a lo incatalogable en general, como si la contemplación de ese prodigio rompiera y superara la usual dicotomía del sujeto que califica y el objeto paciente. Pero no cabe indagar ahora en algo que se caracteriza por ser inefable y ajeno a lo común antropológico, cosa que requeriría estudios concretos de tipo místico y/o estético, aunque sirva hacer referencia a 
ello para establecer contrastes que iluminen nuestro asunto. Quede la constatación de que la experiencia humana puede llegar más lejos de lo que la subjetividad ordinaria y el lenguaje presentan, algo situado, por tanto, allende la esfera intersubjetiva.

3.1. La mixtura de naturaleza e historia encuentra en el paisaje un ejemplo privilegiado (no abstracto) para combinar lo que permanece y lo que cambia, pues hay en él un cariz de estabilidad frente al flujo evanescente del tiempo (es el mismo paisaje), a la vez que encierra mutaciones, bien porque haya sido alterado (por la mano del hombre, por los cambios estacionales, etc.) o por la transformación íntima de quien lo observa. Es como si el paisaje sirviera de patrón de medida para la vida humana, dentro de un rango temporal que está mucho más acá de las eras cósmicas y geológicas, adecuado a la hora de discernir entre la repetición de los ciclos ecológicos básicamente iguales o el cambio lineal de cierta envergadura que demanda nuevas explicaciones históricas o biográficas. Los paisajes suelen ser contextos a escala, marcos de referencia elocuentes por sí mismos e indicadores transversales de la propia creatividad humana: son los espejos de lo que perdura o no en el mundo, pero también de nuestra teoría y praxis (cómo los vemos y actuamos sobre ellos o por qué dejamos de hacerlo). Quiero decir, en fin, que hablan del sujeto colectivo que se manifiesta mediante las mil formas de la cultura en sentido sincrónico y diacrónico.

La humanidad se ve reflejada en ese retrato, paradójicamente impreso en lo que no es humano - como el negativo de una fotografía que luego se revela-, con un efecto que trasciende cualquier aspecto concreto de actividad (utilitaria, estética, etc.) para constituirse en la suma de todos ellos. Lo que está detrás de la definición de un paisaje es nada menos que un estilo de vida, unos intereses y unos valores, unos prejuicios y unas creencias, unas ideas y unas técnicas..., las relaciones profundas que dan lugar a la sintaxis y a la semántica mencionadas, en cada época de una manera única, pero con combinaciones y perspectivas variadas. Basta pensar en el papel histórico de la agricultura, la minería, las obras públicas, las vías de comunicación, la intervención paisajística propiamente dicha, etc., para comprender la importancia de lo que se llama paisaje antropogénico como nexo entre territorio y cultura.

$\mathrm{Ni}$ que decir tiene que el resultado es un cúmulo de información (relativa a dimensiones simultáneas y procesuales, explícita e implícita, denotativa y connotativa), que no debe ser olvidada en la reflexión filosófica. Y de nuevo Ortega ofrece una lectura sintética haciendo converger esas vertientes dentro de un marco teórico perspectivista: «El paisaje ordena sus tamaños y sus distancias de acuerdo con nuestra retina, y nuestro corazón reparte los acentos. La perspectiva visual y la intelectual se complican con la perspectiva de la valoración» (Ortega, 1916). Aquí la intersección ya aludida de lo físico y lo metafísico es paradigmática, por así decir: todo lo paisajístico se presenta mediante diferentes tipos de perspectivas que interactúan, cuyo resultado es la sinergia entre la percepción de los objetos, la aplicación de las ideas y las valoraciones correspondientes. Por eso puede decirse que hay un proceso de inte- 
gración de relaciones y significados, lo que convierte a la noción de paisaje en algo unitario y totalizador, hasta el punto de que «la razón geográfica del lugar» influye tanto en el estilo de vida, que puede concluirse que hay una razón topográfica que forma parte de la «razón vital» (Paredes, 1998: 154, 171 y 177). Y todo ello se predica tanto de un sujeto particular como de una cultura, pues aquel siempre expresa a esta en mayor o menor medida.

3.2. Que la sensibilidad personal y colectiva hacia el paisaje se plasma —a la par que es educada por ella - en aspectos culturales queda muy claro en la historia del arte, especialmente a través de la pintura. Un mero recuento de algunos rasgos y épocas así lo acredita: el tono bucólico y pastoril del paisajismo inaugurado en Roma tendrá amplio seguimiento en otras épocas, la grandeza indomeñable de la naturaleza en la tradición china sirve para subrayar la pequeñez de un hombre que le pertenece, la creciente urbanización —en buena medida geométrica- del entorno propia de la modernidad expresa la potencia domesticadora de la inteligencia humana y de una técnica voraz, mientras que la rehabilitación de lo salvaje, característica de la atmósfera romántica, apunta a lo contrario y a la huida de las convenciones, hasta desembocar en la disolución impresionista de los perfiles gracias a los juegos de luces, casi de camino hacia la abstracción paisajista más reciente que opera la dislocación de formas y tal vez de los propios estados de ánimo, definitivamente sublimados.

En estos u otros casos, la representación pictórica alude a patrones estéticos que definen toda una forma de ver el mundo (en los que ahora no cabe entrar), llena de vivencias que convierten al paisaje en algo tranquilo y mesurado o violento e ingobernable, inmenso o acotado, artificioso o agreste sin más. El arte retrata el diálogo multifacético entre naturaleza e historia, mostrando en ocasiones una relación de conformidad entre el orden macrocósmico y el microcósmico, bien sea desde una actitud de conocimiento y poder por parte del hombre o sólo admirada y contemplativa, pero siempre cabalgando los ritmos profundos de la realidad que el paisaje encarna. Sin embargo, también puede connotar rebeldía, sobrecogimiento e incluso exasperación cuando se quiebran las líneas y se traspasa la superficie figurativa para indagar en los abismos telúricos de lo informe. Obviamente, coinciden en ello el orden y el caos que atraviesan a sujeto y objeto o, si se prefiere, lo apolíneo y lo dionisíaco, la luz y la sombra, que troquelan ese diálogo sin remedio.

Tampoco es tan extraño - en otro orden de cosas- que la reflexión desemboque en la espiritualidad como síntesis paradigmática de lo natural e histórico, ni que se hayan establecido asociaciones entre paisajes, climas, culturas y religiones. Tal es el caso del estudioso japonés Tetsuro Watsuji, quien subraya la importancia del medio ambiente y distingue tres grandes tipos que podríamos llamar ecorreligiosos mediante las siguientes conexiones:

a) El clima monzónico es generador de exhuberancia y llamaría a sacralizar la naturaleza y a una actitud de homenaje distendido hacia lo divino, como ocurre en Asia. 
b) La aridez del clima desértico, en cambio, induciría a buscar la salvación en lo trascendente (en lugar de la pobre naturaleza inmanente) y a traducir ese rigor en obediencia absoluta y fiero proselitismo, a la manera monoteísta del judaísmo y el islam.

c) El clima templado, característico de un entorno amable como el de la dehesa, sería, en cambio, propicio a la contemplación racional y a la tolerancia, según la pauta marcada por la Grecia clásica (Watsuji, 2007).

Por supuesto que no hace falta tomar esta teoría al pie de la letra, pero quedan en el aire unos vínculos parcialmente verosímiles entre algunos de esos factores, a condición de que se incluyan otros elementos históricos y no se haga una lectura determinista.

De vuelta al tronco común del discurso, cuando los llamados expertos hablan del horizonte antrópico para referirse en concreto a las modificaciones técnicas del suelo, acaso debería completarse el panorama —en términos antropológicos- con la dimensión espiritual de un horizonte de sentido. Así como en el ser humano se distinguen (sin caer por ello en el dualismo) un plano corpóreo y otro mental, así también podría proyectarse analógicamente al paisaje la misma diferenciación en el seno de una sola realidad. La acción del hombre se convierte en otra fuerza natural más (que erosiona, transporta o sedimenta materiales, pongamos por caso), pero lo hace al servicio de unas necesidades, ideas y creencias que confieren sentido a la faena. Luego lo pragmático, lo valorativo, lo estético e incluso lo religioso vuelven a darse la mano de manera privilegiada en este ámbito. En definitiva, hay un estilo de vida construido en torno a ciertas condiciones ambientales, en la acepción más amplia y profunda del término, y a sus implicaciones de toda clase para la producción y la supervivencia, los ideales y la organización social más adecuada, las normas y los fines derivados, etc., según ha puesto de manifiesto la denominada antropología ecológica (Harris, 1995; Diamond, 2006). El paisaje es, en fin, uno de los ingredientes destacados de ese complejo de circunstancias naturales y artificiales (harto imbricadas a lo largo de la historia) que llamamos mundo.

\section{Lo vital: la carne común del mundo}

Tomo prestado y uso libremente el concepto de carne del mundo de Maurice Merleau-Ponty (1970), con menor tono ontologizante y abstracto, para referirme a la textura común de cuanto existe: en algún sentido, toda realidad natural forma parte del mismo gran cuerpo y los paisajes son la piel que lo envuelve. No se trata de adoptar una postura organicista, claro está, sino de insistir en la fuerza conectiva del paisaje a poco que se le conceda un papel mediador (de interfaz se dice ahora) entre los fundamentos geobiofísicos que sostienen a la vida y la comprensión histórica de su interdependencia con el artificio humano. Es la superficie visible donde emerge el estado general del sistema, por decirlo así, una suerte de espejo del conjunto donde observamos los cambios profun- 
dos a lo largo del tiempo, por ejemplo, en relación con los glaciares, los bosques o los ríos. El paisaje nos habla a escala humana de la complejidad de la biosfera y de la conexión entre lo global y lo local, lo macro y lo micro: es la mónada y el botón de muestra que habla de los grandes procesos desde los puntos de vista particulares de los diferentes ecosistemas. Y haríamos bien en mirarlo con atención, a la vista de lo que está sucediendo en el planeta, pero no sólo con alarma justificada, sino también con placer reflexivo en otros casos.

4.1. Una de las formas más apropiadas para hacerlo de manera conjunta es la llamada estética ecológica y su propuesta de unificar la percepción de naturaleza y cultura a través del arte. Una vez sentado que el paisaje percibido incluye ideas y valores ligados a una situación concreta en el espacio y el tiempo (place identity), no es difícil aceptar que el arte puede influir en la concepción del mundo donde tiene lugar aquella mirada (Prigann, 2000: 39-40). Aquí no basta con captar el entorno - como veíamos más arriba- de acuerdo con unos parámetros culturales, sino que hay que modificarlo mediante intervenciones que ayudan a entender un determinado problema; por ejemplo: la inclusión de reveladoras composiciones plásticas en el marco de una vieja excavación minera que ha devastado el paisaje, o contribuyendo a la modificación decorativa de una antigua fábrica, o mediante el acompañamiento de un río contaminado con objetos en sus orillas. Más allá o más acá del land art, hay un hueco donde la acción estética simboliza otro modo de habitar e interactuar con la Tierra, al margen de las habituales abstracciones cuantitativas y utilitarias.

No menos interesante es recuperar la medida antropológica del cuerpo humano, arraigado en un paisaje, cobijado así entre los inmensos límites de la Tierra y el cielo: «Una estética ecológica tiene su punto angular, su centro definitivo, en la orientación a lo humano. La poesía, en expansión, del espacio es un eco de nuestra experiencia corporal. El paisaje es el espacio de la percepción de nuestro cuerpo [...] nuestro cuerpo en el cuerpo del mundo» (Prigann, 2000: 42). Digamos que, desde el propio cuerpo, se accede de manera fluida al paisaje y, desde éste, al medio ambiente en general, hasta desembocar en el planeta como un todo e incluso en el universo (la bóveda celeste que permanece, sea cual fuere el suelo que pisemos), cual muñecas rusas o escalas de composición no meramente formales sino vividas, pues el impulso artístico permite prolongar unas instancias en otras, sin solución de continuidad, sea mediante creaciones tangibles o imaginarias.

Dicho de manera más genérica, la corporalidad es nuestra forma de situarnos y encajar en lo real, a lo que se suma la opción de embellecerlo o, al menos, percibirlo por vías insospechadas. Así como el propio Merleau-Ponty hablaba de la inserción fenomenológica radical en el mundo gracias al anclaje preconsciente (o pretético) del cuerpo humano y sus dispositivos cinéticos o sensoriales (Merleau-Ponty, 1975), así ahora podemos añadir el muy deliberado producto estético - tomado en sentido amplio- de un cuerpo generador de herramientas y de obras de arte que se siente parte de un paisaje. No en vano, 
las viejas casas o molinos, los ropajes, los objetos rústicos (utillaje, aperos, mobiliario, etc.) acaban por convertirse en piezas con carga estética que hablan de los estilos de vida apegados al entorno que los engendraron. Aquellos que llevaban a cabo una explotación sostenible del medio en la mayoría de los casos y que, aún dentro de su dureza, sabían leer los signos de la Tierra e identificarse con un paisaje.

4.2. Junto a este reconocimiento de la vida sobre la base de una corporalidad común a sujeto y mundo, puede ser conveniente añadir algunas notas complementarias sobre lugares y paisajes específicamente humanos. Quiere decirse que la integración de las diferentes esferas de lo vital — tomando al paisaje como punto de apoyo- se viste ahora con tonos más sociales (nomos) que físicos (physis), aún dando por hecho que son recíprocos, y por ello se trata de espacios más artificiales y reglados de cara a la acción compartida. Ahora no primaría la naturalización de la existencia, sino la humanización de la naturaleza, valga el contraste.

Así, más tarde (para comparar), podremos adscribir o no a los paisajes los mismos rasgos que convierten en relevantes para la vida humana a ciertos lugares en razón del espacio, la cultura, la lengua, etc., según indica Marc Augé:

a) Por ser identificativos para las personas o los grupos, como el lugar de origen.

b) Ser la sede o la expresión en sí mismos de relaciones fácticas importantes para el colectivo, como la residencia.

c) Tener carácter histórico, por ejemplo: los monumentos.

Es patente, entonces, que estos ámbitos tienen una significación poderosa que incluye aspectos relativos a la raíz, al desenvolvimiento y a la trayectoria de unos sujetos. De ahí que hablar de no lugares implica privarlos de valor y referirse a lo que no puede ser «radicado» ni definido mediante esos vínculos que unen lo espacial con lo intersubjetivo, tal como sucede en las salas de espera de los centros de viajes, en los campos de refugiados, en estadios deportivos y centros comerciales, etc. (Augé, 1993) ${ }^{2}$. En estos casos, se produce un relativo vaciamiento de sentido, una suerte de anonimato general donde no caben los nexos convencionales, una tierra de nadie ajena a la auténtica vida en comunidad, todo lo cual implica quedarse desidentificado.

La cuestión (además de rehumanizar esos entornos) es evitar que esta situación de indiferencia se proyecte multiplicada hacia el paisaje natural, considerado como un gigantesco no lugar, irrelevante y anónimo. Es positivo que, en él, todas las personas sean iguales y no se definan por su estatus, pero sin llevar aparejada la frecuente pérdida de responsabilidad ante lo que no es de nadie y se convierte en mera zona de paso. Por el contrario, debe promoverse su con-

2. Aunque uno también piensa en otras variables de no lugares, como las cárceles extraterritoriales tipo Guantánamo, etc. 
sideración como lugar valioso en términos ecológicos, estéticos, etc. (y no solo en los espacios protegidos), precisamente por identificarse con lo común, esto es, con lo que a todos beneficia eventualmente, con independencia de los usos concretos o de su posible lejanía de las rutinas sociales, lo cual supone reforzar con toda clase de significados identificatorios a los espacios naturales y al paisaje inherente, lo que repercute en las personas que los transitan. De hecho, se cumpliría entonces mejor su función básica de prestar refugio acogedor para quienes necesitan escapar del agobio y las imposiciones de la sociedad, dentro de un anonimato bien distinto al de la deshumanización de la gran ciudad.

\section{Para terminar}

El paisaje (silvestre o urbano) resume una serie notable de hechos antropológicos y los convierte en algo unitario, además de hacerlos visibles y tangibles. En él, convergen las condiciones ecológicas y culturales, los afectos personales y los estilos de vida, las prácticas productivas y de explotación, los valores estéticos, educativos e incluso morales (al menos en sentido indirecto) que se le reconocen, etc. Lejos de incurrir en algún fundamentalismo conservacionista (no ligamos este discurso a la ecología profunda, por decirlo en breve), se busca comprender y practicar hasta las últimas consecuencias una suerte de ecoantropocentrismo en el que el tema del paisaje es abanderado y ejemplo paradigmático.

Por otro lado, parece útil tomarlo como antídoto contra la invasión creciente de las realidades virtuales, es decir, todo aquello que disminuye el arraigo característico de nuestra condición espacio-temporal (Espinosa, 2007b) y limita el contacto directo con la carne del mundo. Sin tecnofobia alguna y reconociendo las posibilidades creativas de lo virtual también en este campo, vale la pena reivindicar el efecto terapéutico — nunca mejor dicho— de poner los pies sobre la tierra y perderse en un horizonte que no se controla a golpe de clics. Quizá ya apuntaba en esta dirección sanadora Ortega y Gasset cuando decía: «Los paisajes me han creado la mitad mejor de mi alma» (Ortega, 1906). Y es que ayudan a lograr un tipo de asentamiento menos movedizo para la existencia, que incluye dimensiones personales, colectivas y ecológicas, como se ha visto. Sin paisajes, la vida pierde pie, carece de escenario y de asideros físicosimbólicos, mientras que, con ellos, encuentra un espejo y un alimento inapreciable para la sensibilidad.

\section{Referencias bibliográficas}

Augé, M. (1993). Los no lugares: Espacios del anonimato. Barcelona: Gedisa. Diamond, J. (2006). Armas, gérmenes y acero. Barcelona: Mondadori.

Espinosa, L. (2007a). «La naturaleza bio-cultural del ser humano: El centauro ontológico». En: Coca, J.-R. (coord.). Filosofía, ciencia y tecnología. León: Universidad de León, 129-162. Contextos, 17.

Espinosa, L. (2007b). «El nihilismo virtual en la sociedad hipertecnológica». Ágora, 26 (2), 79-101. 
Gala, A. (1985). Paisaje con figuras. Madrid: Cátedra.

Glacken, C. J. (1996). Huellas en la playa de Rodas. Barcelona: Ediciones del Serbal.

Harris, M. (1995). Nuestra especie. Madrid: Alianza.

Merleau-Ponty, M. (1970). Lo visible y lo invisible. Barcelona: Seix Barral.

- (1975). Fenomenología de la percepción. Barcelona: Península.

Morin, E. (1984). Ciencia con consciencia. Barcelona: Anthropos.

Ortega y Gasset, J. (1906). «La pedagogía del paisaje». En: Moralejas, O. C. I. Madrid, Alianza, I983.

- (1916). «Verdad y perspectiva». En: El espectador I, O. C. II. Madrid: Alianza, 1983, II, 19.

- (1929). «Intimidades». En: Obras completas. Madrid: Revista de Occidente-Alianza, 1983, II, 635.

- (1983). Obras completas. Madrid: Revista de Occidente-Alianza.

Paredes, M. C. (1998). «El simbolismo del paisaje en Ortega». En: Paredes, M. C. (ed.). El hombre y su medio: Perspectivas ecológicas desde Ortega y Gasset. Salamanca: Universidad de Salamanca, 143-179.

Prigann, H. (2000). «Algunas tesis para una estética ecológica basada en la integración del arte, la ecología y la economía». En: Colectivo. Arte con la naturaleza: Percepción del paisaje. Salamanca: Junta de Castilla y León. Consejería de Educación y Cultura.

Watsuji, T. (2007). Antropología del paisaje: Climas, culturas y religiones. Salamanca: Sígueme.

Luciano Espinosa Rubio es profesor titular de Filosofía en la Universidad de Salamanca. Ha dedicado su investigación al pensamiento de Spinoza, a la filosofía de la naturaleza en sentido histórico y sistemático (desde el paradigma ecológico y de la complejidad) y a la antropología, procurando adoptar un enfoque interdisciplinario y atento a los desafíos del presente.

Luciano Espinosa Rubio is Professor of Philosophy at the University of Salamanca. He has devoted his research to the thought of Spinoza, to a historical and systematic approach to the Philosophy of Nature (from the ecological paradigm and the notion of complexity) and to Anthropology, trying to adopt an interdisciplinary approach responsive to the challenges of the present. 


\title{
Reconfiguración del paisaje desde lo común. Una perspectiva ético-estética
}

\author{
Toni Aragón Rebollo \\ Universidad de Salamanca \\ u19944@usal.es
}

\section{Resumen}

El objetivo de este artículo es reflexionar sobre las posibilidades del paisaje como herramienta para construir el espacio desde lo común. Para ello, discutiré la polisemia del paisaje y sus implicaciones en el vínculo entre paisaje y comunidad. Esta reflexión me llevará a criticar los efectos de la hegemonía del sentimiento de lo bello y lo sublime y la visión identitaria existente en nuestra sociedad consumista, así como sus implicaciones en los procesos de participación sobre el paisaje. Como alternativa, expondré las ventajas de una percepción poiética que derivan de una concepción del paisaje como acción dentro de. Se trata de un modo de relacionar el paisaje y la comunidad que contribuye a un modo de habitar y transformar el territorio bajo una concepción de comunidad basada en la communitas de Esposito y en los aportes de la ética del cuidado y del ecofeminismo.

Palabras clave: paisaje; comunidad; percepción poiética; identidad territorial; participación.

\section{Abstract. Re-forming landscape from the common: An ethic-aesthetics perspective}

The aim of this paper is to consider the possibilities of landscape as a tool to build space from the common. To do so, I will discuss the polysemy of landscape and its implications in the landscape-community linkage. This reflection will enable me to criticize the effects of the hegemony of feelings of the beautiful and the sublime and the prevalent view of identity in our consumerist society, and its implications for participation processes regarding the landscape. As an alternative, I will show the advantages of a poietic perception, derived from a conception of landscape as an action inside. This way of relating landscape and community contributes to a certain way of inhabiting and transforming the territory that works under a notion of community based on Esposito's concept of communitas and on contributions from the ethics of care and ecofeminism.

Keywords: landscape; community; poietic perception; territorial identity; participation. 


\section{Sumario}

1. Introducción. Relacionando comunidad y paisaje

2. De la polisemia del paisaje a la cultura del paisaje

3. La belleza de y la identidad con el paisaje en una sociedad consumista

4. La endogamia de los procesos de participación en los paisajes representativos
5. Una percepción poiética para

la reconfiguración del paisaje como lugar de lo común

6. Otro tipo de relación: el paisaje como acción dentro de una comunidad

7. Conclusiones paisajeras

Referencias bibliográficas

\section{Introducción. Relacionando comunidad y paisaje}

La relación entre comunidad y paisaje aparece ya reflejada en el Convenio Europeo del Paisaje (CEP) del año 2000: «El paisaje es un elemento clave del bienestar individual y social, y su protección, gestión y ordenación implican derechos y responsabilidades para todos». Dicha declaración descansa en una dependencia más amplia existente entre la propia calidad de vida y un medio ambiente saludable. Naturaleza y cultura están vinculadas, no son conceptos opuestos (Heyd, 2008). Así, la cultura depende y está fuertemente influenciada por un entorno finito, modificado constantemente por causas bióticas y abióticas. Por ello, cuando hablamos de medio ambiente, surgen cuestiones políticas y éticas que tienen que ver con juicios de valor sobre equidad, intereses, daños y riesgos que implican al otro en sentido amplio (Velayos, 2008: 36). De todo esto se desprende que, para reconocer, respetar, defender y mantener un medio ambiente saludable de manera proactiva, es crucial aprehender que habitamos en el mundo como miembros de una comunidad. Para entender esta implicación, es necesario emplear un sentido de habitar en comunidad más rico que el de sentimiento de un grupo social cuyos miembros comparten una idiosincrasia propia y utilizan un patrimonio común. Como dice Nancy (2001: 151): «El ser no es común en el sentido de una propiedad común, sino que es en común». Por tanto, el sentido de comunidad al que me voy a referir en este artículo implica un modo de formar parte de, de dar $a$, de dejar ser, de cuidar de, de aprender de, de convivir con y de compartir destino con el otro.

Como se puede intuir, este planteamiento participa en la crítica del sentido tradicional de comunidad que Roberto Esposito realiza a través de su idea de communitas (2003, 2009). Esposito recorre la línea de pensamiento limitante de la tradición filosófica que ha categorizado la comunidad como «inmunización», «legitimación», «secularización» y «racionalización» — con especial detenimiento en Hobbes, Rousseau, Kant, Hegel y Heidegger- (2009: 25-44). En efecto, quiero distanciarme de todo sentido que reduzca el «ser-en-común» a una identidad propia y que hegemonice un mecanismo de "sacrificio» y 
«culpa» del individuo respecto al grupo (2003: 25 y 43). Además, para reflexionar sobre este sentido de habitar en comunidad - y como complemento a esta crítica-, considero necesario integrar el replanteamiento aportado por el pensamiento ecofeminista y la ética del cuidado sobre el modo de relacionarnos con nosotros mismos, con el otro y con el mundo. Las razones para ello son varias, pero se pueden resumir en la visión de Alicia Puleo (2011: 403-404):

[El ecofeminismo] tiene que ser un pensamiento crítico que reivindique la igualdad, contribuya a la autonomía de las mujeres [y de los hombres], acepte con suma precaución los beneficios de la ciencia y la técnica, fomente la universalización de los valores de la ética del cuidado hacia los humanos, los animales y el resto de la Naturaleza, aprenda de la interculturalidad y afirme la unidad y continuidad de la Naturaleza desde el conocimiento evolucionista y el sentimiento de compasión.

Para comprender la complejidad de todas estas relaciones, existe un concepto catalizador: el paisaje. Diferentes disciplinas, como la ecología del paisaje, reconocen su naturaleza holística y compleja, por lo cual sitúan en el centro del mismo la gran interdependencia entre el ser humano y su entorno (Bunce, 2009: 5). Dicha característica respalda su potencial para reflexionar desde el ser en común. Esto da pie a mi tesis principal de que paisaje y comunidad se pueden vincular más allá de la identidad territorial y del sentimiento estético. Para ello, concebiré el paisaje como una acción creadora de percibir una porción del mundo que el mismo ser humano habita y transforma en comunidad. En el fondo, como intentaré mostrar, dicha forma perceptiva expresa un modo de habitar en el mundo donde el sujeto es protagonista y aporta su bagaje, sus diferencias, su ideología, su tiempo y su interpretación. Además, según mi opinión, trabajar dicha actitud contribuye en gran medida a reflexionar sobre cómo nos gustaría desarrollarnos a nivel personal y colectivo. Por consiguiente, en definitiva, el paisaje abre una posibilidad más para reformularnos la cuestión sobre cómo es el mundo en el que queremos vivir, tan necesaria para la consecución de la felicidad individual.

\section{De la polisemia del paisaje a la cultura del paisaje}

La primera dificultad que uno encuentra a la hora de reflexionar sobre el paisaje es su polisemia. La definición más repetida es la recogida en el CEP: «Cualquier parte del territorio tal como la percibe la población cuyo carácter sea el resultado de la acción y la interacción de factores naturales y/o humanos». Recupero estas palabras porque, pese a su simplicidad, recogen los cuatro aspectos más característicos reflejados en otras definiciones más complejas: percepción, territorio, tiempo y población (Herrera, 2009: 26-30). Aunque todos ellos están estrechamente imbricados, es fácil comprobar cómo las distintas disciplinas ponen un mayor foco en uno u otro. La cuestión no es trivial, ya que nuestras decisiones pueden variar en función del criterio considerado (véase Santos y Ganges, 2002-2003). La amplitud de sus posibles consecuencias dependerá de nuestra 
posición de poder — entendido a la manera de Foucault—, pero, al tratarse de cuestiones ambientales, hay que tener siempre presente que nuestras acciones y no acciones tienen implicaciones directas o indirectas en el otro.

Por ejemplo, desde cierto pensamiento cientificista, se ha venido priorizando el interés de un paisaje en la funcionalidad, la productividad y la eficiencia de los servicios ecosistémicos. Debido a su objetividad, los aportes de la ecología del paisaje son una de las principales fuentes de información utilizadas para la elaboración de los planes estratégicos de ordenación del territorio presentes en las políticas de desarrollo, conservación y gestión de valores naturales y culturales (Vila et al., 2006: 152). Esto se debe a los motivos siguientes:

1. Esta disciplina atiende a los procesos internos de cambio asociados a la estructura y a la funcionalidad del paisaje, haciendo hincapié en su carácter sistémico (Forman y Godron, 1986).

2. Sus estudios proporcionan resultados cuantitativos fácilmente contrastables basados en «índices del paisaje» —índice de diversidad, de conectividad, de fragmentación, de forma, etc.— (Vila et al., 2006: 163).

El problema es que justificar valoraciones cualitativas a partir de estudios exclusivamente cuantitativos es una actitud reduccionista o falaz. Si no se hace explícito, uno puede obviar que, detrás, está operando una concepción mecanicista del medio ambiente cuyo origen reside en los ideales modernos de dominación de la naturaleza ya planteados por Francis Bacon en La Nueva Atlántida. Y, aunque dicha visión teleológica esté muy asumida en la actualidad por la cultura capitalista neoliberal, no debería significar una predeterminación sistemática del sentido de las decisiones relativas al presente y al futuro de un paisaje. Es más, esta idea ni siquiera aparece dentro de los objetivos del CEP ratificado por el Estado español en 2007. Según el artículo 1, se ordena para «mejorar, restaurar o crear paisajes» bajo unos criterios de calidad paisajistica que son formulados mediante procesos participativos por las «aspiraciones de las poblaciones en lo que concierne a las características paisajísticas de su entorno".

Con este ejemplo quiero, además, resaltar una inquietud compartida por muchos profesionales del paisaje: la necesidad de incluir como «índices del paisaje» aspectos sociales, económicos, estético-visuales y culturales que ayuden a analizar y a explicar la sincronía y la diacronía paisajística de una manera más completa. Autores como Santos y Ganges (2002-2003) y Santos y Ganges y De la Riva (2003) han mostrado la importancia de la percepción como uno de los grandes valores de los paisajes. Joan Nogué (2010: 125) va más allá y señala que «el paisaje solo existe en relación con el ser humano en la medida en que éste lo percibe y se apropia de él». Estas visiones están relacionadas con el gran protagonismo que, según mi opinión, tiene la percepción en la conexión del ser humano con el entorno, con los otros y con su propio proyecto de vida. Esta idea se ve con claridad en el mismo Nogué (2010: 127), quien recalca el papel del paisaje en el proceso de creación, mantenimiento y consolidación de 
identidades territoriales, lo cual ayuda a generar modos de relacionarnos con la naturaleza que resuelvan los conflictos entre el uso del territorio y el impacto ambiental. Con ello, resalta la urgencia de una nueva cultura territorial que siga criterios de gestión sostenible de los recursos naturales y patrimoniales bajo un nuevo tratamiento y una consideración del paisaje en su conjunto. Una importante iniciativa es el Manifiesto por una nueva cultura del territorio promovido en 2006 por el Colegio de Geógrafos y la Asociación de Geógrafos Españoles, y al que se han adherido más de cuatrocientos profesionales sensibilizados con la ordenación territorial.

La península Ibérica es un lamentable ejemplo de transformación territorial promovida por criterios económicos que ha derivado en una gran pérdida patrimonial. Según Nogué (2010: 134), para transformar el territorio sin perder su discurso y mantener los imaginarios de los paisajes, son necesarios procesos de participación que, a su vez, se enmarquen en una cultura del paisaje dentro de esta cultura territorial. Su propuesta es más profunda aún. Una cultura del paisaje, además de sensibilizarnos sobre las conexiones y las consecuencias de nuestras acciones individuales y colectivas, contribuye a:

1. Generar una percepción estética del mundo necesaria para enriquecer nuestra manera de vivir y promover actuaciones proambientales.

2. Formar un sentimiento de identidad con el territorio que promueva la conservación del medio ambiente.

Las dos actuaciones están interconectadas y se retroalimentan. La experiencia estética tiene un gran poder formativo - como bien ha estudiado López Quintás (2004) — y el sentimiento de identidad alimenta el apego a la tierra. Sin embargo, si se analiza bajo el tamiz de una sociedad consumista como la occidentalizada, en ambas aparecen resistencias o desviaciones llamativas. A continuación, me detendré en este aspecto, ya que condiciona la idea de vínculo entre paisaje y comunidad que estoy desarrollando.

\section{La belleza de y la identidad con el paisaje en una sociedad consumista}

El ejercicio del turismo, sobre todo en las áreas protegidas, es una de las formas de ocupar el tiempo libre que más se ha promocionado desde el siglo xx (Muñoz, 2008). Es indudable su valor como motor alternativo de la economía local. Por ello, el atractivo del paisaje para el turista se ha extendido como herramienta de gestión territorial (Zuluaga, 2006). Este tipo de turismo es asumido socialmente como una actividad terapéutica para salir de la rutina diaria. Los destinos elegidos son, mayoritariamente, paisajes en los que el imaginario común localiza un ideal de belleza o un sentimiento de lo sublime muy influenciados por la visión estética de la naturaleza del pintoresquismo romántico (Ortega, 1999; Riesco, 2003; Blanco, 2007; Berque, 2009). Bajo este amplio planteamiento, predominan dos grandes tendencias: 
1. El modo romántico de naturaleza virgen ligado a una belleza pura con connotaciones religiosas (véase Diegues, 2005) o a lugares inhóspitos llenos de aventuras cuya experiencia recuerda a los grandes relatos de viajes del siglo XIx (islas Galápagos, selva amazónica, etc.).

2. El modo moderno de naturaleza dominada y ordenada racionalmente por el ser humano (belleza de los jardines de Versalles, sentimiento de lo sublime matemático suscitado por los olivares de Jaén o las dehesas de Monfragüe, etc.).

Estas imágenes imperan en los tipos de paisaje que los medios de comunicación de masas y las administraciones públicas promocionan y conservan. Sin embargo, como muy bien apunta Riesco (2003: 61-66), esta visión del paisaje establece, en el imaginario social actual, una separación entre los llamados entornos proximales, aceptados socialmente por su carga representativa y simbólica como lugares para la vida pública, el ocio, la residencia (espacios naturales protegidos, áreas rurales pintorescas, etc.), y los distales o negligentes, maginados estética y éticamente por su carencia de forma y sentido común (zonas de periferia, polígonos industriales abandonados). Cabe enfatizar que los términos distal y proximal se refieren al alejamiento respecto del cuerpo simbólico; y por tanto no debe entenderse como distancia espacial.

Los proximales se caracterizan por generar un sentimiento identitario forjado bajo la idea de que el paisaje es una construcción social fruto de la acción colectiva de una sociedad — como señalaba Nogué-. La idea de fondo está apoyada por la revalorización de estos entornos para producir y reforzar identidades territoriales. Éstas son fáciles de conseguir en paisajes «bien conservados» $\mathrm{y}$ "definidos» por una lógica clara asociada a un modo de vida determinado (el sagayés zamorano, el serrano salmantino, el tirolés suizo, etc.). Sin embargo, sensibilizar en un sentimiento de apego ligado a la identidad territorial no implica necesariamente una toma de decisiones consensuadas en comunidad, y puede legitimar la consideración de un modo de vida local tradicional como el más auténtico para ese territorio - y, por tanto, que se considere el de mayor validez-. Este hecho, como intentaré mostrar en el siguiente punto, puede disminuir la capacidad volitiva de los actores implicados en los procesos de participación sobre el futuro y la calidad del paisaje en comunidad.

Por ejemplo, la modificación del territorio que dio lugar hace siglos a los característicos bancales en Arribes del Duero no se debió a un consenso paisajístico propiamente dicho. Fueron las características agrestes del terreno y una forma de vida determinada las que motivaron este sistema de cultivo aterrazado que, en la actualidad, se está abandonando. Con esto no quiero decir que los bancales dejen de ser fruto escultural del trabajo colectivo de muchos individuos durante varias generaciones, y que no haya que conservarlos. Lo que quiero resaltar es que no se puede atribuir directamente un sentimiento de comunidad a partir de una manifestación cultural, aunque ésta proceda de una colectividad de individuos cooperadores identificados con su territorio. Por otro lado, la identidad con el territorio no es garantía necesaria ni suficiente 
para la conservación de un paisaje. Paisajes donde es fácil encontrar esa identificación territorial han sido degradados por cambios en el uso del suelo o la despoblación —como ha ocurrido en multitud de pueblos de Castilla-León-. Es más, muchas de las campañas conservacionistas proceden de colectivos - no identificados con ese territorio- motivados por dos de los valores más cotizados cuando se habla de paisaje: el patrimonio y la belleza singular.

Sin embargo, esta creciente tendencia social a impulsar la identificación entre habitante y territorio en los paisajes proximales y a conservar el patrimonio y la belleza según cánones pintoresquistas han traído como consecuencia una mayor despreocupación por los paisajes distales que carecen de ellos. Así, lejos de potenciar una actitud proactiva y crítica respecto de la realidad próxima, esta visión ha derivado en el aumento del desapego de muchas personas en relación con el propio paisaje distal donde viven (Nogué, 2006). Es más, se ha producido un acostumbramiento a la percepción diaria de falta de belleza, de apego, de consenso y de sentido común. La actitud generalizada es proyectar reiteradamente el presente en el futurible disfrute del tiempo de ocio, en vez de situarlo en lo cotidiano. En este contexto, hay al menos dos direcciones de fuga que fortalecen la suspensión de la capacidad crítica:

1. Hacia un interior domesticado con la adquisición del mayor número de gadgets tecnológicos y electrodomésticos para convertir una casa refugio en una «república independiente».

2. Hacia los teatros proximales pintorescos exteriores seleccionados por agencias de viajes, blogs, revistas dominicales, etc. Aquel lugar que aparezca repetido en más listas top ten será el más atractivo para visitar.

Estos teatros recrean la imagen intocable, aventurera y moderna del paisaje gracias a que uno puede perderse, encontrar y experimentar un sinfín de sensaciones organizadas de lo bello y lo sublime en entornos preciosistas al aire libre.

Además, en nuestra actualidad occidentalizada, hay un ingrediente relativamente nuevo: una escapada no es completa si no se memoriza digitalmente todo, en formato JPG o AVI, para su inmediata difusión a través de las redes sociales en busca de mil «Me gusta» y su almacenamiento posterior. Este tipo de práctica encaja con «la sociedad del espectáculo» retratada por Debord en 1967. En ella, lo real se habría sustituido por lo representado, y lo verdaderamente social, por su imagen representada: «El espectáculo no es un conjunto de imágenes, sino una relación social entre las personas mediatizada por las imágenes» (1967: 38). Este modo de vivir también me recuerda al «flotar en el aire» de Heidegger (1927: \$\$35-38). Según él, las «habladurías» nos llevan a una sensación de «falta de paradero» fundada en la «avidez de novedades». Félix de Azúa (2011), por su parte, lo describe con gran acierto a través de su análisis de la sociedad del «acabamiento del presente». Esta estructura social alimenta ciertas expectativas para hacer más llevadero el presente, pero, en realidad, enmascara la eliminación de futuro. Lo que ponen de manifiesto estos autores, pero más explícitamente Azúa, es la prevalencia, en nuestra cultura capitalista 
occidental, de un sentir generalizado de falta de ilusión y esperanza por lo cotidiano. Hay un conformismo aliviado a base de novedad, de criterio de autoridad de expertos y de futuribles. En el fondo, según mi opinión, se podría establecer una analogía entre el auge de dicha actitud respecto del paisaje y La condición postmoderna de Lyotard (1979): la necesidad de novedad y el consumo de la narración con función legitimatoria de los paisajes proximales son una vía de escape ante la caída de los "metarrelatos» acaecida en los paisajes distales. Muchos individuos escapan de la incertidumbre diaria de sus paisajes sin sentido hacia otros donde poder encontrar lógicas discursivas universalizables, claras, fáciles de entender y que transmitan calma y seguridad. Éstas se encuentran, sin duda, en parajes bien idealizados, promocionados, interpretados y conservados, donde cualquiera puede relajarse percibiendo relictos — generalmente rurales- de vida auténtica.

La consecuencia directa de este modo de estar es múltiple. Junto a lo ya señalado, se encuentra un mayor grado de fragmentación con el otro y la pérdida del sentimiento de res publica como espacio de lo común. Una muestra de ello son: la falta de vecindad creciente, la marginación, la degradación y el desuso de muchos espacios públicos y la proliferación de no lugares. Además, también disminuye nuestra capacidad crítica debido a la rapidez, sencillez y comodidad que estas vías de escape suponen respecto al intento de recuperar el espacio cotidiano - gracias sobre todo a nuestra red de transportes y a las ya mencionadas y autorizadas listas top ten de paisajes por descubrir- Son necesarias más iniciativas como las de pequeños municipios, asociaciones de vecinos o artistas que introducen un elemento crítico en la cotidianidad distal.

Un ejemplo de sensibilización crítica fue Yo Amo la M30, de Aeraciega y Basurama. Se trató de un viaje turístico en autobús descapotable por las obras de la circunvalación madrileña M30 que cambiaron el paisaje de Madrid durante años. Según las palabras de sus organizadores, el objetivo fue "provocar una reflexión performática y carnavalesca al respecto de un proyecto surrealista - [era] dudoso pensar que el proyecto [estuviera] movido por motivos puramente urbanísticos o de servicio al ciudadano-》 (2007). Dicha crítica ponía de manifiesto la política de fomento del vehículo privado en Madrid, la cual tiene repercusiones climáticas y saludables, más allá de las afecciones que padecen los habitantes de esa zona de la ciudad.

Otro ejemplo, este de participación crítica, es la reseñable acción comunitaria de la Asociación de Vecinos de Oliver «Aragón» (véase <http://parqueoliver. org $>$ ). A partir de conseguir, en 1993, la construcción de un parque en el barrio tras una década de reivindicaciones, se instituyó la Asociación Coordinadora del Parque Oliver. Su objetivo era y es conseguir la apropiación vecinal del espacio, entendiendo ésta en el sentido definido por la psicóloga e investigadora del CNRS-París, Marie-José Chombart de Lauwe (1976): «Apropiarse de un lugar no es sólo utilizarlo, sino establecer con él una relación, integrarlo a las vivencias propias, enraizarse, dejar en él la huella propia y convertirse en actor de su propia transformación». Este modo de habitar el barrio continúa dando frutos. En la actualidad, están desarrollando, junto con la Sociedad 
Zaragoza Vivienda, del Ayuntamiento, un plan de desarrollo sostenible y comunitario, cuyo objetivo es diseñar y poner en marcha de forma concertada una serie de medidas de desarrollo social, económico, cultural, medioambiental, comunitario y de revitalización urbana (AVV de Oliver "Aragón», 2010; Miguillón et al., 2010). Esta experiencia de un barrio en el que viven comunidades diversas (payos, gitanos e inmigrantes) es un magnífico ejemplo de trabajo para mejorar la calidad de vida de sus habitantes a través de una gestión participada del paisaje desde lo común. En definitiva, en palabras de la coordinadora: «Quizá la mejor lección aprendida es que, en una zona degradada de la ciudad como es el barrio Oliver, se ha desarrollado una visión optimista para intentar mejorar las situaciones desfavorecidas».

Un último ejemplo es el proyecto Juzbado libro abierto: Un viaje a través de las emociones del paisaje y la literatura, el cual ha concurrido a los premios Conama 2013. El Ayuntamiento de este pequeño municipio salmantino de 280 habitantes lleva años desarrollando un proceso participativo de desarrollo rural y anteponiendo como valores el prestigio y el orgullo del hecho rural, la sensibilidad hacia el paisaje y el mundo de las letras a través de las emociones. Desde una perspectiva del bien público y compartido — con la participación voluntaria de vecinos y no vecinos-, están creando y reinventando espacios comunes. El objetivo es, mediante diferentes actividades, contribuir a legitimar una nueva forma de contemplación, reflexión y disfrute de su medio cercano (Jablonski y Rubio, 2013). Esta iniciativa no solo conserva el patrimonio local dinámicamente, sino que también entiende el futuro como construcción común en la que participan locales y no locales. Como decía su alcalde, Fernando Rubio de la Iglesia, en un bando de 2009: "Juzbado continúa escribiendo su libro abierto".

Lamentablemente, este tipo de iniciativas son poco comunes y, además, pese a su gran valor y esfuerzo, no reciben una repercusión merecida. Al contrario, en la actualidad, los medios de comunicación masivos potencian más adquirir un modo de bien-estar en vez de tratar de reconfigurar la propia existencia desde el bien-vivir. Una cultura consumista como la occidentalizada fomenta la creación de islotes acomodados e inmóviles, a base de fijar en los individuos costumbres aceptadas por la sociedad del «espectáculo» o del «acabamiento del presente», que garantizan a los individuos el poder seguir «flotando en el aire». Todo esto disminuye la capacidad crítica y la asimilación del vínculo con el otro y con el entorno. Ambas son fundamentales para una reconfiguración del paisaje dentro de un sentimiento de comunidad que amplíe los límites de lo propio y ayude a aprehender el mundo en el que habitamos. En cualquier caso, estos ejemplos ilustran cómo, incluso desde un paisaje distal, también se puede trabajar para despertar la conciencia crítica sobre lo cotidiano, el sentimiento de identidad y su importancia en los procesos de participación. Sin embargo, como abordaré en el siguiente punto, un exceso de identidad puede traer consigo una serie de consecuencias limitantes para la relación entre paisaje y comunidad. 


\section{La endogamia de los procesos de participación en los paisajes representativos}

En el punto anterior, comencé hablando de los beneficios de la pseudoterapia ocupacional que ofrece el turismo de paisajes proximales en una sociedad consumista. Esta circunstancia denota, además, un proceso paradójico en el que merece la pena detenerse: a la vez que aumenta la fragmentación comunitaria, se refuerza el vínculo entre turistas y locales. Así se está fijando una eficiente división de roles establecida y aceptada socialmente. Para los paisanos que viven y trabajan allí, los turistas son una fuente de ingresos importante, pero su presencia en exceso es molesta. Y, para estos últimos, los primeros son los actores del teatro experiencial «auténtico» que están consumiendo durante su tiempo de ocio. Ambos contribuyen a modificar un mismo territorio - construcción de infraestructuras adaptadas al turismo, cambios de ritmos de vida, aparición de nuevos sonidos y ruidos, etc.- - Dicho de otro modo, se está produciendo un fenómeno sincrónico y diacrónico en dos sentidos divergentes:

1. De manera partidista, porque sus intereses y sus objetivos personales son diferentes.

2. De manera colectiva, porque todos provocan cambios en el paisaje.

Se trata de una divergencia creciente dentro de una misma colectividad que no contribuye a crear una idea de paisaje como espacio donde estar, donde crecer, donde vivir desde lo común. Al contrario, el paisaje se reduce a espacio teleológico: espacio para contemplar, para trabajar, para dormir, para disfrutar, etc.

Esta fractura entre el turista y el local aumenta cada día más, debido a programas de sensibilización que tienden a identificar representativamente en exceso al habitante con su territorio. A su vez, este tipo de sensibilización también dirige al turista enseñándole la interpretación correcta —en su más pura esencia - para disfrutar del espectáculo experiencial de fin de semana. Este modelo representativo-esencial impregna también los procesos de participación, los cuales, como señala el CEP, son fundamentales para decidir sobre la calidad del paisaje. A mi juicio, en ellos se involucra a los habitantes de una manera equivalente a la descrita por Pierre Bourdieu como el «espacio de los posibles». Bourdieu se refiere al ámbito artístico, pero considero su análisis muy útil para reflexionar sobre los procesos de participación del paisaje, porque ambos integran objetos perceptibles estéticamente y constituidos históricamente. En concreto, «espacios de los posibles» y paisaje están ligados a un momento histórico (político, social, cultural, etc.) y tienen un capital específico - vinculado también a dicha historicidad- que entra en juego y se hereda. Esta noción incluye el capital simbólico, cultural, social, científico y económico, el interés y la estrategia seguida por los distintos actores que intervienen y se mueven dentro de ese campo (Bourdieu, 2010: 145-150). De modo que los «espacios de los posibles» se definen a través de «la relación entre habitus como sistema de disposiciones ligado a una trayectoria social y a un campo» 
(Bourdieu, 2010: 40). Un «campo» es el espacio de juego históricamente constituido con sus instituciones específicas y sus leyes de funcionamiento propias, en el que los individuos tienen disposiciones (maneras de ser, de percibir, etc.) y esquemas (modos de pensar, de inventar, etc.) ligados a sus trayectorias personales, que, a su vez, son producto de condiciones sociales, históricas, etc. (Bourdieu, 2010: 39). De ahí la importancia del estado de relaciones de fuerza entre las distintas posiciones de las instituciones y demás agentes implicados. En definitiva, un proceso de participación sobre el paisaje también se puede entender como un espacio estructurado de lo posible, donde los agentes implicados hablan de recursos susceptibles de generar interés y luchan por legitimar su discurso (Bourdieu, 2010: 123-127).

A partir de este análisis, cabe pensar que si el criterio hegemónico en el paisaje es la identidad, y ésta se entiende como representación de un territorio, quienes no se identifiquen con esa idea perderán legitimación dentro de un proceso participativo. Por tanto, cuando se acepta socialmente la identidad como la verdad hegemónica — aunque sea por consenso-, se corre el riesgo de generar endogamia dentro del proceso, lo cual es nefasto para cualquier intento participativo futuro. Dicho de otra forma, a partir de un momento $O$ —en el que sí hubo diversidad-, una opinión discordante será considerada forastera, no representativa, adulterada, alejada de los intereses «reales»y, por lo tanto, no autorizada. En resumen, si prevalece la idea de identidad como representación de una esencia presente en el paisaje y se sensibiliza en este sentido, es muy probable que, a medio plazo, se limite la posibilidad de introducir variaciones futuras en él que vayan en contra de ese ideal hegemónico.

Alguien puede pensar que la crítica siempre es posible dentro de cualquier posición, por muy dogmática que sea. Además, existen muy buenos trabajos sobre cómo realizar proyectos de sensibilización y participación paisajística, gestionar conflictos territoriales y demás cuestiones, cuyo objetivo es fortalecer la cohesión social (por citar algunos de los más completos: Heras, 2002; Busquets y Cortina, 2009; Nogué et al., 2011; Busquets, 2011). Pero, más allá de obviar ambas realidades, lo que quiero remarcar en este punto es que, en cualquier caso, la prioridad puede pasar del habitar en común al mantenimiento y la conservación integrales de aquello que nos identifica y nos representa apropiadamente, en detrimento de otras opciones. Sirva de ejemplo la llamada de atención que realiza Nogué sobre los indeseables efectos geopolíticos internos sufridos bajo la hegemonía del arquetipo paisajístico por parte del discurso nacionalista en la Cataluña seca (Nogué, 2006: 23). Esa zona «supuestamente sin valor identitario" ha sufrido una mayor dejadez institucional e impacto paisajístico, al recibir infraestructuras como centrales nucleares, el mayor complejo petroquímico, etc. (Nogué, 2010: 131).

Este riesgo se puede ver también cuando participan todos los agentes implicados. Si tenemos en cuenta la fractura comunitaria ya señalada con respecto al paisaje, me parecería probable que se produjera una lucha aún más partidista por la legitimación de los discursos en función de los intereses particulares de cada rol. Bajo este planteamiento, para un local, un turista aportaría en el tema 
económico, pero no tendría nada que decir sobre la identidad de un paisaje — su valor simbólico-. Su participación se reduciría a proponer ideas nuevas para aumentar la oferta y la calidad turística. Pero este hecho complementario y enriquecedor puede derivar en procesos donde tengan más poder los actores turísticos. Esto ya sucede en algunas poblaciones de la selva amazónica o del altiplano peruano, donde se imponen las ventajas económicas del turismo como directriz motora para el mantenimiento de un paisaje y un modo de vida. Esto es así porque el objetivo final pasa a ser hacer vivir al turista una experiencia «auténtica» (Fabíula, 2006). Un caso más extremo es el de pueblos como Pedraza (Segovia) o Calatañazor (Soria), convertidos en un escenario precioso, genuino. Se trata de localidades ricas en restaurantes y tiendas, pero pobres en paisanaje diario por su inhabitabilidad. Por todo esto, creo que es muy importante sensibilizar en la identidad territorial; pero si ésta se liga a una visión excesivamente representativa del paisaje, puede resultar limitante. Para reconfigurar el paisaje como espacio de lo común, es necesario plantear los procesos participativos desde el habitar en comunidad. Pero, además, tienen que estar acompañados de programas de sensibilización paisajística que transmitan una noción de percepción estética que supere posiciones identitarias y representativas, como muestran el barrio de Oliver o el pueblo de Juzbado.

\section{Una percepción poiética para la reconfiguración del paisaje como lugar de lo común}

La pregunta clave en este punto es: ¿Cómo se ha llegado en Occidente a establecer una concepción esencialista del paisaje? Lograr una respuesta de alta resolución superaría las pretensiones de este trabajo, ya que requeriría un profundo ejercicio de arqueología del saber. Sin embargo, puedo avanzar críticamente en el discurso entresacando dos nuevos rastros: contemplación y significación. Ambos se corresponden con un sentido prosaico de entender la percepción que ha reducido el potencial del paisaje para la vida en comunidad. Utilizo el término prosaico por dos motivos:

1. Según su etimología, significa 'que anda en línea recta' (del latín prōsus, Corominas, 2003: 478) —ello me sirve para describir una percepción representativa que, ciertamente, entiende la mirada correcta en dos líneas: a) hacia una esencia común por descubrir, y $b$ ) hacia una subjetividad por respetar.

2. Por oposición, con una percepción poiética (creadora) que sintoniza con la idea de creación y apertura del mundo de Deleuze (1993: 110).

El paisaje, en el rastro contemplativo, es un conjunto de formas que pueden generar un sentimiento estético en el sujeto. Kant, en su crítica del juicio, resituó la belleza desde el objeto hasta el sujeto a través de una percepción desinteresada del mismo. Este modo de percibir, junto con la «educación del buen gusto» de Hume y la promoción de la visión subjetiva romántica y pin- 
toresquista, han sido hegemónicos en relación con el paisaje. El segundo rastro - complementario del anterior - está relacionado con la idea de que la identidad territorial puede verse representada en el paisaje. Aceptar esto último implica que la percepción de un territorio construido socialmente posee un significado sustancial propio - en forma de símbolo o lo que sea- susceptible de ser representado. Como consecuencia:

1. La estética contemplativa subjetiva totalmente la mirada —la percepción de la belleza es inmune a las razones del otro.

2. La estética del significado objetiva el paisaje - la percepción correcta de un territorio pasa por encontrar su verdadero sentido.

Los individuos pueden captarlo en mayor o menor grado, dependiendo del conjunto de conocimientos y experiencias que tengan sobre dicho lugar. Sin embargo, ambas traen consigo una apropiación cosificada del territorio y de la percepción que limitan el vínculo entre paisaje y comunidad.

Para entender esta limitación, hay que tener presente que no percibimos en abstracto, sino en un contexto histórico, social y personal. Por ejemplo, Bourdieu (2010: 235-247) analiza cómo la mirada es "génesis social» producida por la historia y reproducida por la educación. Pero, como individuos con nuestras capacidades y discapacidades, percibimos que esta amplitud también es cotidiana:

1. En y durante un tiempo determinado (una noche, diez segundos, en nuestro tiempo de ocio, trabajando, etc.).

2. En y desde un espacio determinado (un camino, un mirador, un lugar público o privado, etc.).

3. Según el modo como hemos accedido a dicho espacio (andando, en coche, por casualidad, como visitantes, cansados, alegres, etc.).

4. Con todos nuestros sentidos disponibles.

Para reflexionar sobre todo esto, considero interesante la «estética de la recepción» de Jauss tal como la presenta en su Pequeña apología de la experiencia estética (1972: 57-59). Según él, comprender y crear convergen en la experiencia estética del sujeto, con lo que distingue una función cognitiva - aisthesis - y una función social — catarsis - del arte. En este marco, Jauss recupera la teoría de Aristóteles de los efectos de la tragedia sobre el espectador: temor y compasión. Así, la catarsis tiene que ver con la transformación del sujeto, con su «liberación de y liberación para» (Jauss, 1972: 41). Esto permite superar la oposición entre experiencia estética y praxis moral — como también mostraba López Quintás-. Para ello, también son positivos los procesos de identificación del espectador con lo representado.

Como ocurre con la obra de arte, el paisaje se puede entender como un objeto estético que únicamente existe en el marco configurado por su recepción (Jauss, 1972: 9), o sea, dentro de la interpretación histórica, de su carácter 
público y de un sujeto que lo percibe críticamente como construcción social (1972: 76). El punto de vista de la recepción — como introduce Daniel Innerarity - «hace ver las cosas de nuevo y proporciona, mediante esta función descubridora, el goce de un presente más pleno; [...] anticipa experiencias futuras y abre así el campo de juego de acciones posibles» (Jauss, 1972: 18). En este contexto receptivo, una percepción poiética es un proceso abierto de formación y enriquecimiento de experiencias, propias y ajenas, capaz de reducir el riesgo de endogamia secundario que apuntaba en los procesos representativos de participación. Esto se puede dar si entendemos que el comportamiento estético influye en el mundo del que formamos parte. Con ello se conforma un momento de sociabilidad. La tesis fuerte de esta reflexión es que esa creación no es exclusiva del productor del paisaje, sino que, quien percibe, también participa activamente en su conformación.

Sensibilizar en este sentido puede liberar en gran medida al paisaje de la cosificación identitaria esencialista y legitimar el diálogo abierto entre los distintos roles desempeñados por quienes comparten un paisaje. Así, se construye una vía para conformar una comunidad en la que el otro contribuya como un elemento más. La lucha por la legitimación del discurso pierde sentido frente a la riqueza de la diversidad. Aquí, la diversidad no es entendida como un multiculturalismo débil, sino como una variedad de modos de estar que comprometen a la acción y tienen consecuencias en el otro. Bajo este marco, también tiene cabida otro matiz necesario en los procesos de participación y, por extensión, en la comunidad: la tolerancia ligada a la empatía, entendida como tolerancia positiva autocrítica a la manera de Thiebaut (1999: 68). Tolerar no es solo soportar al otro, sino tratar de dejarle ser y comprenderle para admitir que puede tener razones que yo no tengo. En definitiva, esta concepción abre la posibilidad de integrar y aprender de las razones del otro, lo cual es fundamental para modificar la forma de habitar con él y con nosotros mismos dentro de un vínculo fuerte entre comunidad y paisaje.

\section{Otro tipo de relación: el paisaje como acción dentro de una comunidad}

La línea argumentativa que he seguido lleva a considerar la relación entre paisaje y comunidad como una acción dentro de. Esto requiere un cambio conceptual del estático sustantivo "paisaje» por un dinámico "paisajear». Esta licencia deleuziana — sin pretensiones de acuñamiento — no es una idea en sí novedosa. Cualquier noción de paisaje interioriza una acción que incorpora un carácter temporal, poblacional, territorial y perceptivo. El tiempo transcurre, las poblaciones cambian, las condiciones bióticas y abióticas del territorio varían a lo largo del tiempo y, como he señalado en el punto anterior, la percepción también presenta un enorme dinamismo. Si se obvia esto, la relación entre sociedad y comunidad se ve limitada por la asunción del paisaje como representación de la construcción colectiva y de una identidad esencial que el sujeto percibe y experimenta. Como señala el propio Esposito (2003: 44-45), 
una vez que la comunidad se identifica con un pueblo, una tierra y una esencia «queda amurallada dentro de sí misma y separada de su exterior». Con ello se alimenta el mito de "la interiorización de esa exterioridad, la duplicación representativa de su presencia y la esencialización de su existencia» en quienes conciben la comunidad como «la salida al exterior a partir del sujeto interior» (Esposito, 2003: 44). Este análisis se manifiesta muy bien en las consecuencias endogámicas que merman la capacidad volitiva en los procesos de participación sobre el paisaje.

Por el contrario, el paisaje como una acción creadora enriquece su relación con la comunidad si se entiende dentro de relaciones sociales que incluyen nuestra memoria secular y simbólica y nuestro sentimiento de destino común en un mundo y un tiempo limitados. Las implicaciones éticas son muy importantes. ¿Qué aportan los límites a la comunidad? Bataille, por ejemplo, busca la comunidad en el mayor límite común que tiene la vida: la muerte (cit. por Esposito, 2003: 200-201). Para Bataille, siguiendo la interpretación de Esposito, la imposibilidad de apropiarnos de toda muerte, al no poder experimentarla, nos estrecha en un horizonte común que configura el deseo de comunidad, ya que sí podemos reflexionar sobre la experiencia de la muerte del otro (Esposito, 2003: 199). Con ello, saca a relucir en toda su crudeza el sufrimiento, el dolor y la muerte presentes en nuestro ser viviente. Esta idea es elemental en contraposición a la tendencia actual de esconder de nuestras vidas todo lo considerado negativo. Esta realidad no solo abre la puerta a sentirnos conscientemente como seres limitados que comparten unos recursos limitados, sino que permite la emergencia del cuidado como elemento clave de nuestro vivir ético. Este planteamiento se viene trabajando intensamente desde el ecofeminismo - pero, pese a su gran fuerza, sin un espacio de visibilidad merecido- . No solo se trata de tener presente siempre nuestra mortalidad, sino también de vivir con honestidad hacia los límites y las posibilidades de nuestra propia vida y la del otro. En definitiva, es un modo fuerte de «vivir deliberadamente» — como maravillosamente expresó Thoureau en su obra Walden.

\section{Conclusiones paisajeras}

Como he intentado mostrar, cualquier consideración del paisaje como representación de una esencia identitaria origina fuertes limitaciones para la conformación de una comunidad. Ésta última, siguiendo la crítica de Esposito y la noción de Nancy, va más allá de compartir un patrimonio y una serie de intereses partidistas de individuos dentro de una colectividad. Una salida crítica y constructiva es la que ofrece el ecofeminismo a través de visiones como la de Alicia Puleo. El paisaje y la comunidad se pueden relacionar complementando el significado de acciones como cuidado de la tierra y del otro, dejar ser, tolerancia, empatía, convivencia o experiencia de uno mismo. Para construir una cultura del paisaje que incluya a la comunidad, es fundamental diseñar y ejecutar procesos de interpretación, sensibilización y participación que amplíen los límites de la percepción prosaica e integren las posibilidades que ofrece un 
sentido poiético. El paisaje se vincula, así, con la comunidad como acción dentro de. A través del paisajear se ponen abiertamente en juego estas acciones enumeradas tan importantes dentro de una comunidad. Por todo ello, considero plausible postular la reconfiguración del paisaje como una herramienta crucial para habitar desde lo común.

Un resumen del potencial de esta tesis se encuentra en el poema de Gabriel Celaya que lleva por título La poesía es un arma cargada de futuro. El paisaje como percepción poiética no puede ser reducido a un «lujo cultural» concebido por los «neutrales». Hay al menos tres motivos para ello:

1. No se puede constreñir en un estilo propio producido por una determinada historia que define la identidad de un pueblo.

2. No posee una esencia sustancial cuyo significado es un signo asumido y controlado por el discurso de la razón de los expertos.

3. No se puede promover la belleza pintoresca o el sentimiento de lo sublime como los grandes valores del paisaje. Más aún si se reduce la percepción estética a la educación humeana, la formación kantiana del buen gusto o la subjetividad romántica.

Cuando la experiencia estética es poiésis, el paisaje como acción creadora abre un futuro en todos los habitantes de espacios tanto proximales como distales, tanto locales como no. Sólo hay una vida, y vivir con futuro requiere fuertes dosis de creación, realidad, responsabilidad y compromiso. Por ello, creo firmemente que la percepción del paisaje expuesta en este artículo puede contribuir a remover el vacío de la "sociedad del acabamiento de presente» - $\mathrm{O}$ «del espectáculo»—, en las que hay rigidez identificativa, conformismo, espectáculo ilimitado y «avidez de novedades». Esto es, ayuda a descosificar la vida del individuo y a reconfigurar su modo de habitar en el mundo desde la comunidad. Por consiguiente, como conclusión final, reconfigurar el paisaje desde lo común es una gran herramienta para:

1. Contribuir a conseguir que los habitantes superen críticamente las restricciones de la identidad territorial y de lo social como mera colectividad.

2. Abrir futuro en individuos que viven sabiéndose limitados, diferentes del otro, y que quieren eliminar dicotomías mecanicistas.

3. Resituar a la persona en un presente del cuidado, en el cual uno se preocupa por dejar ser al otro, amplía el horizonte del sentido del bien-vivir en común y se pregunta activamente por su felicidad. 


\section{Referencias bibliográficas ${ }^{1}$}

Aeraciega y Basurama (2007). Yo Amo la M30 [en línea]. <http://basurama. org/video_b06_yo_amor_m30.htm> [Consulta: octubre 2013].

AVV DE Oliver "Aragón» (2010). "Plan de desarrollo sostenible y comunitario del Barrio Oliver (Zaragoza)». Ponencia de las Jornadas sobre la participación ciudadana en las politicas ambientales [en línea]. Valladolid: RED (Asociación de Educadores Ambientales de Castilla y León). <http://www.educadoresambientales.com/archivo/PonenciasJP2010/ VALLADOLID\%20JORNADAS\%20SEPT2010-reducido.pdf> [Consulta: septiembre 2013].

Azúa, F. de (2011). Diccionario de las artes. Barcelona: Debate.

Berque, A. (2009). El pensamiento paisajero. Traducción de Maysi Veuthey. Madrid: Biblioteca Nueva.

Blanco, C. (2007). "De la invención del paisaje a la "moral del paisaje" como género pictórico».Terr@Plural, Ponta Grossa, 1 (2), 41-60.

Bourdieu, P. (2010). El sentido social del gusto: Elementos para una sociología de la cultura. Traducción de Alicia Gutiérrez. Buenos Aires: Siglo Veintiuno.

Bunce, B. (2009). «Preámbulo al libro de presentación de ECOPÁS». En: Iglesias Merchán, C. et al. Ecología del paisaje y seguimiento ambiental: Feedback en materia ambiental. Madrid: ECOPÁS.

Busquets, J. (coord.) (2011). La sensibilización en paisaje: Un reto para el siglo XXI. Barcelona: Generalitat de Catalunya. Departament de Territori i Sostenibilitat.

Busquets, J. y Cortina, A. (coords.) (2009). Gestión del paisaje: Manual de protección, gestión y ordenación del paisaje. Barcelona: Ariel.

Сhombar de Lauwe, M. J. (1976). «L'apropiation de l'espace par les enfants i precessus de socialisation». En: Korosec-Sefaty, P. Apropiation de l'espace: Actes de la tressième conference international de psycologie de l'espace construite. Estrasburgo.

Corominas, J. (2003). Breve diccionario etimológico de la lengua castellana. Madrid: Gredos.

Debord, G. (1967). La sociedad del espectáculo. Prólogo, traducción y notas de J. L. Pardo. Valencia: Pre-textos, 2008.

Deleuze, G. y Guattari, F. (1993). ¿Qué es filosofía? Barcelona: Anagrama.

Diegues, A. C. (2005). El mito moderno de la naturaleza intocada. Sao Paulo: NUPAUB-USB.

Esposito, R. (2003). Communitas: Origen y destino de la comunidad. Traducción de Carlo Rodolfo Molinari. Buenos Aires: Amorrortu.

- (2009). Comunidad, inmunidad y biopolitica. Traducción de Alicia García. España: Herder.

1. Esta bibliografía sería injustamente incompleta si no incluyera los aportes, los comentarios y las críticas, directos e indirectos, de Lucía Carrillo, Elena Melero, Isabel Motos, Patricia Olmo, Carmen Rodríguez, Luís Sáez y Carmen Velayos. Muchas gracias a todos ellos. 
Fabíula, P. (2006). «Considerações preliminares sobre produto turístico étnico». Pasos (Revista de Turismo y Patrimonio Cultural), 4 (2), 143-152.

Forman, R. T. T. y Godron, M. (1986). Landscape Ecology. Nueva York: Wiley and Sons.

Heras, F. (2002). Entretantos: Guía práctica para dinamizar procesos participativos sobre problemas ambientales y sostenibilidad. Valladolid: GEA.

- (2007). «La participación como proceso de aprendizaje y conocimiento social». Educación Social, 35, 28-42.

Herrera Calvo, P. (2009). «De paisajes, ecologías y, por qué no, seguimientos...». En: Iglesias Merchán, C. et al. Ecología del paisaje y seguimiento ambiental: Feedback en materia ambiental. Madrid: Ecopás.

Heyd, T. (2008). «Relacionando cultura y naturaleza». Azafea: Revista de Filosofía, 10, 161-178.

Heidegger, M. (1927). El ser y el tiempo. Traducción de José Gaos. Madrid: Fondo de Cultura Económica, 1971.

Jablonski, J. y Rubio, J. (2013). «Juzbado libro abierto: Un viaje a través de las emociones, el paisaje y la literatura». Ponencia de la Escuela de Alcaldes 2013 [en línea]. Almenara de Tormes: Junta de Castilla y León. <http:// www.jcyl.es/web/jcyl/MedioAmbiente/es/Plantilla100/1284256168 895/_/_/_> [Consulta: julio 2013].

Jauss, H. R. (1972). Pequeña apología de la experiencia estética. Traducción e introducción de Daniel Innerarity. Barcelona: Paidós, 2002.

López Quintás, A. (2004). La experiencia estética y su poder formativo. Bilbao: Universidad de Deusto.

Lyotard, J. F. (1979). La condición postmoderna. Traducción de Mariano Antolín Rato. Madrid: Cátedra, 2000.

Miguillón, J.; Benedí, S. y Enciso, M. E. (2010). Diagnóstico estratégico del barrio Oliver: Zaragoza Vivienda-Ayuntamiento de Zaragoza y AVV Oliver-Aragón [en línea]. Zaragoza: Millenium 3. <http://www.ebropolis. es/files/File/Documentos/diagnostico-Oliver.pdf> [Consulta: octubre 2013].

Muñoz, J. C. (2008). "El turismo en los espacios naturales protegidos españoles, algo más que una moda reciente». Boletín de la AGE, 26, 291-304.

Nancy, J. L. (2001). La comunidad desobrada. Traducción de Pablo Perera. Madrid: Arena Libros.

Nogué, J. (2006). «La necessària revisió dels paisatges de referència». Nexus, $36,16-26$.

- (2010). «El retorno al paisaje». Enrahonar, 45, 123-136.

Nogué, J. (ed.) (2007). La construcción social del paisaje. Madrid: Biblioteca Nueva.

Nogué, J.; Puigbert, L.; Bretcha, G. y Losantos, À. (eds.) (2011). Paisatge i educació [en línea]. Olot: Observatorio del Paisaje de Cataluña / Barcelona: Departamento de Enseñanza de la Generalitat de Cataluña. Plecs de Paisatge. Reflexions, 2. <http://www.catpaisatge.net/esp/documentacio_ plecs_ref_2.php> [Consulta: agosto 2013]. 
Ortega Cantero, N. (1999). «Romanticismo, paisaje y geografía: Los relatos de viajes por España en la primera mitad del siglo XIX». Ería, 49, 121-128. Puelo, A. (2011). Ecofeminismo para otro mundo posible. Madrid: Cátedra. Riesco-Chueca, P. (2003). «Estéticas privadas y estéticas públicas en la producción y consumo del paisaje rural». En: FernándeZ, J.; Roldán, F. y Zoido, F. (eds.). Territorio y patrimonio: Los paisajes andaluces. Granada: Instituto Andaluz de Patrimonio Histórico. Consejería de Cultura, 58-75. Santos y Ganges, L. (2002-2003). "Las nociones del paisaje y sus implicaciones y la ordenación». Ciudades, 7, 41-68.

Santos y Ganges, L. y Rivas, J. L. de las (2003). «En torno al papel del paisaje en la planificación espacial». IV Congreso Internacional de Ordenación del Territorio, Política Regional, Urbanismo y Medio Ambiente. Zaragoza.

Thiebaut, C. (1999). De la tolerancia. Madrid: Visor. La Balsa de la Medusa. Tilden, F. (1977). La interpretación de nuestro patrimonio. Traducción de Pablo Salas. Madrid: Asociación para la Interpretación del Patrimonio, 2006.

Velayos, C. (2008). Ética y cambio climático. Bilbao: Desclée de Brouwer.

Vila Subirós, J.; Varga Linde, D.; Llausàs Pascual, A. y Ribas Palom, A. (2006). "Conceptos y métodos fundamentales en ecología del paisaje (landscape ecology): Una interpretación desde la geografía». Documents d'Anàlisi Geogràfica, 48, 151-166.

Zuluaga, P. A. (2006). «Una mirada al paisaje como recurso turístico». Revista Interamericana de Ambiente y Turismo, 2 (2), 76-82.

Toni Aragón Rebollo es licenciado en Biología y experto universitario en Gestión y Conservación de Flora, Fauna y Espacios Protegidos por la Universidad de Salamanca. En la actualidad, se encuentra terminando la licenciatura de Filosofía por esta misma universidad. Durante años, ha complementado su experiencia como biólogo — sobre todo investigando vertebrados - con su labor como formador, educador, intérprete y comunicador ambiental en diferentes partes del mundo: Castilla y León, islas Galápagos (Ecuador) y selva amazónica (Perú). Su principal campo de interés es la conservación de la naturaleza desde un punto de vista ético-estético. En concreto: estudiar como la felicidad y la percepción influyen y condicionan nuestra manera de habitar y conservar el mundo.

Toni Aragón Rebollo holds an Expert Degree in Management and Conservation of Wildlife and Protected Areas and a BS in Biology from the University of Salamanca, where he is currently finishing a BA in Philosophy too. He has done some research on vertebrates and has worked in environmental training, in communication and as an interpreter in different parts of the world: Castilla y León (Spain), Galapagos Islands (Ecuador) and the Amazon Rainforest (Perú). His deep interest in nature involves a twofold dimension, aesthetic and ethical, focusing on how our sense of happiness and our perception may influence and determine our ways of inhabiting and preserving the world. 



\title{
Topofilia, paisaje y sostenibilidad del territorio
}

\author{
Francisco Garrido Peña
}

Universidad de Jaén

fpena@ujaen.es

Fecha de recepción: 1-12-2013

Fecha de aceptación: 4-3-2014

\section{Resumen}

En este trabajo, realizamos un análisis de las funciones evolutivas que tiene el amor al territorio y al paisaje (topofilia). Estas funciones son, básicamente, dos: fijar la población al territorio y establecer relaciones de solidaridad con las generaciones futuras y la comunidad biótica. Entendemos la topofilia como un instrumento biocultural de adaptación de nuestra especie. Las emociones estéticas y morales que el paisaje provoca son de mucha utilidad para la construcción de una economía moral ecológica. A este uso ecológico y reflexivo del amor al territorio, le llamamos topofilia, que puede ser útil para evitar el despotismo generacional en las decisiones democráticas.

Palabras clave: paisaje; territorio; sostenibilidad; ecología; topofilia; evolución.

Abstract. Topophilia, landscape and sustainability of the territory

In this study, we analyze the evolutionary functions of the love of territory and landscape (topophilia). These functions are basically two: to fix the population to the territory and to establish solidarity with future generations and the biotic community. We understand topophilia to be a biocultural instrument for the adaptation of our species. The aesthetic and moral emotions that landscape causes are very useful for the construction of a moral and ecological economy. We call this ecological and reflexive love of the territory topophilia, arguing that it can help avoid generational despotism in democratic decisions.

Keywords: landscape; territory; sustainability; ecology; topophilia; evolution.

\section{Sumario}

1. Introducción $\quad 5$. Conservación del paisaje, topofilia

2. ¿Qué entendemos por topofilia? y solidaridad intergeneracional

3. ¿Y qué entendemos por paisaje? 6. Conclusiones

4. Indisponibilidad individual Referencias bibliográficas de la topofilia y del paisaje 


\section{Introducción}

De los miles de millones de conversaciones por telefonía móvil que tienen lugar cada hora en las ciudades y en los suburbios del mundo, la mayoría, sean privadas o de negocios, comienzan con una declaración del paradero o la ubicación aproximada de quien llama. La gente necesita identificar de inmediato y con precisión el lugar donde se encuentra. Es como si les persiguiera la duda de que tal vez no estén en ninguna parte. Circundados por tantas abstracciones, tienen que inventarse y compartir unos puntos de referencia transitorios.

(John Berger)

El capitalismo busca permanentemente crear un paisaje social y físico a su propia imagen y de acuerdo con sus propias necesidades en un momento particular del tiempo, e igualmente menoscaba, perturba e incluso destruye ese mismo paisaje en un momento posterior. Las contradicciones internas del capitalismo se expresan mediante la configuración y la desconfiguración incesantes del paisaje geográfico. Ésta es la melodía con la que la geografía histórica del capitalismo debe bailar sin parar.

(David Harvey)

El conflicto ecológico es el producto de la asimetría entre la capacidad de carga de los territorios y las poblaciones que estos territorios soportan, dadas unas tasas determinadas de extracción y consumo de recursos naturales. La distribución de las poblaciones a lo largo del territorio, así como su reproducción, son esenciales en el mantenimiento de cierto equilibrio imperfecto y tendencial entre población y territorio (González y Toledo, 2011). El territorio es el espacio material donde se efectúa el intercambio metabólico entre sociedad y ambiente. La relación y la disposición entre población y territorio determinan en gran medida los tipos de metabolismo. Para que esta distribución sea ecológicamente óptima y social, así como políticamente factible, han de darse un conjunto de factores de naturaleza diversa, entre los cuales está la identificación simbólica y emocional entre población y territorio (Barkow et al., 1992).

En este artículo, pretendo explorar los usos de un concepto como el de topofilia en relación con el paisaje como horizonte de identificación y reconocimiento de formas singulares y satisfactorias de habitabilidad de un territorio. Para indagar en esta relación entre topofilia y paisaje, vamos a adentrarnos en dos dimensiones que fortalecen este vínculo y que han favorecido evolutivamente una distribución ecológicamente óptima de la población. El paisaje define lo que puede ser una especie de topografía emocional de la sostenibilidad. Las dos dimensiones de esa topografía emocional son:

a) La funcionalidad evolutiva y ecológica de la topofilia dentro de la cual se inserta la atracción hacia el paisaje propio. 
b) La conservación del paisaje como un estímulo para la solidaridad intergeneracional.

Con este breve programa de trabajo, tratamos finalmente de establecer la funcionalidad evolutiva y, por tanto, ecológica de las ventajas adaptativas y comparativas que se desprenden de los sentimientos de topofilia vinculados a paisajes determinados, asociados azarosamente a emociones de reconocimiento colectivo. Este tipo de estímulos emocionales son especialmente útiles en un momento de crisis ecológica, como contraste y contrapeso a los riesgos y a los impactos de la globalización neoliberal, la movilidad y la concentración de las poblaciones.

El fortalecimiento de los vínculos entre población y territorio forma parte de una estrategia global de resiliencia socioecológica (Wilson, 1999). La agroecología, por ejemplo, habla de la necesidad de realizar un proceso de recampesinización del mundo rural y de la agricultura si queremos afrontar con éxito estrategias ecológicamente sostenibles de producción y alimentación (Van der Ploeg, 2010). Pues bien, esa recampesinización no es sino una parte de ese otro proceso más global de reterritorialización de la vida social, de la política y de la economía. La topofilia, en el plano de las emociones colectivas, conectadas al paisaje propio, puede ser un buen dispositivo social de impulso de esta reterritorialización del metabolismo social.

\section{2. ¿Qué entendemos por topofilia?}

La noción de sentido del lugar ha sido aplicable habitualmente al ámbito restringido de los espacios urbanos, pero es perfectamente extensible al paisaje natural, y en general al medio físico, donde las ciudades y los pueblos se insertan, en cuanto todo lugar habitado está cargado de significaciones sociales (Lindón, 2007; Lefebvre, 1986). Estas significaciones no son sino el sistema de señales culturales por medio de las cuales una comunidad reconoce un territorio como habitable y refuerza las habilidades en los manejos más eficientes de los ecosistemas.

Pero las señales no sólo persiguen orientar la habitación eficiente del lugar, sino también algo que es esencial para que esto sea posible: reforzar el sentimiento de pertenencia a ese lugar por medio de emociones sociales vinculadas a experiencias comunes y repetidas en torno al paisaje, la luz o el clima. Estas experiencias comunes se expresan en forma de emociones estéticas, lúdicas, religiosas o de rituales de parentesco, funerarios y otros (Tyrtania, 2009).

Así, el sentido del lugar es, en gran medida, el sentido de pertenecer a ese lugar a través del placer que aportan las sensaciones asociadas a él, ya sean estas directas (visuales, auditivas, térmicas, olfativas) o indirectas (simbólicas, rituales) (Yi-Fu, 1980). La psicología ambiental y la geografía, así como la ecología del paisaje, han trabajado con profusión sobre estas significaciones. Este sentimiento de atracción hacia el lugar es lo que Yi-Fu (1974) ha denominado topofilia. 
¿Qué explicación evolutiva tiene la topofilia? Originalmente, esta explicación es la misma que la etología otorga al sentimiento de territorialidad de determinadas especies en virtud del acotamiento de un espacio para el aseguramiento de los recursos necesarios para la reproducción (alimentación y emparejamiento). Este sentimiento topofílico está ya presente tanto en las comunidades cazadoras recolectoras, como en las comunidades campesinas, así como en las sociedades modernas.

En las sociedades cazadoras recolectoras, la topofilia se expresaba por medio de cosmologías holísticas y animistas, donde la comunidad se indiferenciaba del territorio. Existía un continuo ontológico entre la especie humana, el territorio y otras especies. Para un cazador recolector, el paisaje no existía, pues este y el mundo constituían una misma cosa. La topofilia no era un conjunto de sentimientos específicos, sino que todo sentimiento estaba indisociablemente vinculado al territorio y al hábitat (Mead, 1964).

La complejidad demográfica y ecológica que incorporaron las comunidades campesinas supuso una sofisticación cultural de la topofilia y añadió nuevas funciones evolutivas a la topofilia primitiva. ¿Cuáles son estas nuevas funciones? De manera preferente, son tres:

a) Fijar la población al territorio.

b) Reforzar los lazos intergeneracionales (la tierra de nuestros padres, la patria).

c) Limitar la disposición generacional de los recursos disponibles.

Sirve, pues, para distinguir entre el espacio sagrado (lo indisponible, lo intocable, lo no negociable) y el profano (aquello que puede ser dispuesto en virtud de los intereses, el campo del negocio). De esta manera, fija la población a un territorio que ya conoce y para el cual ha demostrado tener habilidades adaptativas, estableciendo obligaciones morales hacia el pasado y hacia el futuro, así como hacia otras formas de vida del entorno. La topofilia campesina sigue teniendo un fuerte componente holístico, pero existe ya una cierta diferencia entre comunidad y territorio, con un grado de abstracción mayor. La topofilia campesina crea las bases de una economía moral hacia el territorio que establece una serie de pagos y recompensas sociales en base al grado de altruismo cooperativo que los individuos sean capaces de desplegar hacia los compromisos comunes en defensa de su entorno (Thompson, 1989).

Si la emergencia de las culturas campesinas elaboraron una representación topofílica del territorio y del paisaje mucho más compleja y cultural que las que representaban las comunidades cazadoras y recolectoras, son las sociedades modernas las que construyen la forma más abstracta y separada de topofilia, que se objetiva en ideas como la nación, la patria o la etnia.

Es entonces cuando el paisaje aparece como tal bajo la forma de objeto estético y artístico y como marcador de identidad de la nacionalidad o de la etnicidad. Es un paisaje que ya es, en gran medida, el reflejo de una ruralidad perdida, pero que remite a un pasado natural feliz, sin las convulsiones de la vida urbana e industrial. En las promesas arcaizantes del romanticismo y del idealismo nacio- 
nalista de los siglos XIX y Xx, la comunidad étnica o nacional utópica es representada bajo formas de paisajes bucólicos de naturalezas perdidas.

Así pues, la topofilia de los cazadores recolectores era animista, la de las comunidades campesinas era holística y la moderna es agonística y antagonista. Los sentimientos topofílicos han sido parte del arsenal emocional de motivación de la movilización social nacionalista, racista o etnicista. Este uso agonístico de la topofilia moderna ha sido manejado por el cosmopolitismo liberal como un poderoso argumento contra cualquier sentimiento de pertenencia local.

No es de extrañar que tanto las culturas imperiales como el actual modelo de capitalismo globalizado hayan construido discursos muy críticos sobre la topofilia, pues esta representa un serio obstáculo para la movilización de poblaciones y de recursos naturales que los imperios o el capitalismo globalizado necesita. El afincamiento y el enraizamiento de las poblaciones al territorio es un impedimento real para su disponibilidad inmediata allá donde el mercado los necesite bajo la forma de mano de obra y/o consumo. El empoderamiento social que se deriva de ese enraizamiento es, también, un impedimento para la disponibilidad y la vulnerabilidad política de las poblaciones para el modelo de democracia mínima y líquida que la globalización neoliberal impone.

Por todo ello, sostenemos en este trabajo que la topofilia postindustrial cobra un nuevo sentido crítico y emancipatorio en el horizonte de las transiciones socioecológicas como dispositivo emocional que vincula y empodera a la población con relación al territorio. De esta manera, la asunción reflexiva (crítica) de la topofilia original comporta un vigoroso estímulo para el desarrollo de las bases emocionales colectivas de la sostenibilidad en la época del capitalismo globalizado y desterritorializado (Harvey, 2006; Mostafavi y Najle, 2004).

\section{3. ¿Y qué entendemos por paisaje?}

El paisaje no es sino el conjunto de símbolos bioculturales (estímulos sensibles, especialmente visuales y olfativos, asociados a emociones e ideas singulares) que identifican y singularizan un territorio social y ecológicamente determinado. El paisaje está dentro de lo que Toledo y Barrera-Basols han llamado la «memoria biocultural de la especie» (Toledo y Barrera-Basols, 2008). El paisaje está relacionado con la elección del hábitat, algo crucial para nuestra especie durante decenas de miles de años. Refiriéndose a la relación entre paisaje y selección del territorio, Dennis Dutton nos dice lo siguiente sobre la importancia de la elección de un territorio: «La elección de un hábitat era una cuestión crucial de vida o muerte para las poblaciones (y los protopobladores) del pleistoceno" (Dutton, 2010: 42).

La formación de patrones de identificación de los paisajes seleccionados como más aptos para ser habitados se ve favorecida por estímulos emocionales, tal como ocurre en cualquier fenómeno de fortalecimiento de la memoria, tanto individual como colectiva (Linden, 2010; Tyrtania, 2009). Aquellos que 
han desarrollado más afectos asociados a la memoria de los hábitats por medio del paisaje han contado con una potente ventaja evolutiva. La topofilia es, así, el resultado de la selección natural de la memoria biocultural.

Incluso cuando nos referimos a paisajes urbanos, las constantes sensitivas nos remiten a los paisajes naturales (la luz, el color, los olores). Aunque el paisaje como objeto biocultural es un producto de las comunidades campesinas, ya existen relatos y simbología asociados al paisaje en las comunidades de cazadores recolectores, tal como se puede comprobar en la orientación animista de sus rituales sagrados.

¿Hasta qué grado la topofilia no es sino una derivación del animismo primitivo? Es una cuestión que no podemos abordar aquí, pero de la que, en parte, hemos dado cuenta anteriormente en la breve clasificación histórica que hemos realizado de los modelos de topofilia. Pero esta pregunta nos sitúa en una línea de continuidad con los vínculos emocionales entre territorio y comunidad a lo largo de las distintas fases evolutivas. La persistencia de rasgos animistas en las culturas campesinas parece reforzar esta continuidad con las formas anteriores de resignificación social del territorio.

El paisaje es, pues, la representación biocultural de la memoria evolutiva de una comunidad que une al territorio afectivamente a través de la topofilia. Pero esta definición, desde una perspectiva evolucionista y ecológica, parece entrar en contradicción con el hecho de la existencia de un paisaje óptimo ideal común a todas las comunidades, tal como ha demostrado el proyecto Peoplés choice y los trabajos y el análisis de la sociobiología aplicados a los símbolos y a las formas estéticas (Wilson, 1999).

Hay formas de paisaje comunes a toda la humanidad independientemente de su ubicación geográfica o cultural (Orians y Heerwage, 1992). En el paisaje óptimo universal bañado del color azul, aparecen siempre la cercanía del agua, la lejanía de las montañas, la presencia de valles, praderas, árboles, vegetación, animales. Todos estos elementos forman parte, en un grado u otro, de los paisajes particulares de cada comunidad, pero no son fieles imágenes de cada uno de ellos. Este paisaje ideal parece que responde a dos condiciones de la memoria biocultural: primero, se aproxima mucho a lo que debieron ser los paisajes originales de nuestra especie en la sabana africana y, segundo, contiene los elementos básicos para la habitabilidad de un territorio (agua, animales, masas forestales, luminosidad, llanura).

\section{Indisponibilidad individual de la topofilia y del paisaje}

Pero, ¿cómo se compatibiliza la tesis de la topofilia y la del paisaje ideal universal? Miremos, antes que nada, las condiciones de ese paisaje ideal. Es escaso y tiene una capacidad de carga muy limitada como para ni siquiera soportar a las comunidades humanas existentes en el pleistoceno. Por lo pronto, la expansión humana habría sido imposible si no hubiésemos sido capaces de desarrollar condiciones y conductas de adaptación a otros paisajes en otro tipo de territorio. Para que esas nuevas condiciones y conductas adaptativas fueran 
factibles, eran necesarios sentimientos y emociones asociados, eso es la topofilia, que reforzaran la dispersión en el espacio (frente a la insostenible concentración en los territorios óptimos) y la adaptación a las condiciones ecológicas que azarosamente tocaban en suerte. La topofilia, como dispositivo biocultural, hace que no deseemos lo mejor cuando esto es incompatible con lo posible. No amamos nuestro paisaje porque sea el mejor, sino porque es nuestro, algo muy chocante para la mentalidad moderna imperial y omnimeritocrática. La irracionalidad aparente de estos sentimientos es, en realidad, su fortaleza.

Esto significa que el hecho de que la asociación emocional a un paisaje, por medio de la topofilia, sea arbitraria, constituye una de las fortalezas adaptivas y ecológicas de la misma. El sentimiento hacia "la patria chica», lejos de ser un signo de atraso cultural, como quiere entender el cosmopolitismo imperial, es un indicador de inteligencia evolutiva. Si, como hemos dicho, la concentración de toda nuestra especie en los paisajes ideales ya era ecológicamente inviable en el pleistoceno, ¿cuánto no iba a serlo en etapas sucesivas después de la aparición de la agricultura?

Cuanto más ha aumentado la complejidad social, mayor necesidad hay de realizar una distribución descentralizada de los núcleos de población y de geodiversidad de los territorios habitados.

La destrucción de los lazos sociales y ecológicos de las poblaciones rurales con el entorno (paisaje) ha supuesto, por el contrario, un auténtico drama social y ambiental en África y en América Latina, como también lo está suponiendo en India y China. Esta concentración de la inmensa mayoría de la población en unas pocas megalópolis es el resultado de una doble acción combinada de pobreza material (destrucción de las formas de producción y reproducción local) y de pobreza cultural (la recuperación de la atracción fatal hacia el paisaje óptimo, que, en este caso, es la gran ciudad) (González y Toledo, 2011).

La distribución aleatoria de la población en el territorio anterior a la Revolución Industrial es mucho más eficiente evolutivamente que la concentración producida por la irracionalidad del desarrollo capitalista. Éste se basa en la explotación de la racionalidad «irracional» de los intereses privados, enfrentados unos a otros en juegos competitivos. La concentración de la población en poco espacio y en pocos territorios, no solo es empírica e intuitivamente perniciosa, sino que también lo es desde una valoración teórica, como nos muestra el principio de Lotka, que es el principio organizador de la evolución desde un prisma termodinámico. Este nos dice: «en todo instante considerado, la selección natural va a operar de tal manera que se incremente la masa total del sistema orgánico, la tasa de la circulación de la materia a través del sistema y el flujo energético total a través del sistema, en tanto esté disponible un residuo no utilizado de materia y energía» (Lotka, 1925: 23).

Sin contrapesos bioculturales como la topofilia, la tendencia será hacia un uso intensivo de los recursos allí donde más abundan y hacia un abandono de los territorios menos eficientes. Pero eso sería así si la selección natural operara unilateralmente y a una sola escala, cosa que, como sabemos, no es 
real (Novak, 2006). Los dispositivos bioculturales son dispositivos evolutivos del mismo rango que los dispositivos caloríficos o genéticos. El capitalismo globalizador ha roto esta integralidad de los dispositivos evolutivos, estimulando solo aquellos que tienden a desarrollar la racionalidad egoísta y competitiva, lo cual ha fomentado la concentración de la población y la disolución de los lazos colectivos de las comunidades, comenzando por la ruptura emocional con el paisaje propio.

Lo que para la racionalidad egoísta y no cooperativa es irracional en la topofilia (la indisponibilidad individual de los afectos identitarios con el paisaje y el territorio), es racional para la racionalidad colectiva de especie que ha gobernado nuestro éxito evolutivo (Allegrini et al., 2004). Las elecciones azarosas de larga duración suponen un mecanismo de elección más igualitario y eficiente que las elecciones individuales intencionales de corta duración y objetivos inmediatos (Elster,1981).

Hay mucha más sintonía entre las elecciones azarosas reiteradas y las elecciones democráticas (cooperativas) también reiteradas que entre estas últimas y las agregaciones de elecciones individuales egoístas (Axelrod, 1996 y 2011). En las acciones colectivas intencionales o en los procesos de adaptación evolutiva, reside una racionalidad ampliada que no puede ser mucho más útil para el diseño del futuro en la imprescindible, y difícil, alianza entre democracia y sostenibilidad. Hay mucha más sintonía entre las elecciones azarosas reiteradas y las elecciones democráticas (cooperativas) reiteradas que entre estas últimas y las agregaciones de elecciones individuales egoístas. En las acciones colectivas no intencionales o en los procesos de adaptación evolutiva, reside una racionalidad ampliada que nos puede ser mucho más útil para el diseño de una democracia pensada para decrecer y no para crecer infinitamente, como hasta el presente (Garrido, 2009).

\section{Conservación del paisaje, topofilia y solidaridad intergeneracional}

Uno de los grandes retos para esta alianza imprescindible entre democracia y sostenibilidad ecológica reside en la evitación del despotismo generacional en la toma de decisiones colectivas (Garrido, 2012). Por despotismo generacional, entendemos aquellas decisiones que, tomadas por una sola generación, clausuran o lesionan irreversiblemente derechos y recursos de las generaciones futuras. La dificultad para evitar ese tipo de despotismo reside en varios planos de la arquitectura institucional de la democracia.

Por un lado, nuestra democracia se sostiene sobre la voz, el voto y la representación de sujetos e intereses activos y presentes en el escenario social y político.

Las generaciones futuras son una comunidad ausente, al igual que la comunidad biótica es una comunidad silenciosa. Por otro lado, las bases evolutivas de la cooperación social tienen, en la «reciprocidad fuerte», una de las motivaciones más poderosas (Gintis, 2003; Allen et al., 2013). La comunidad ausente de las generaciones futuras difícilmente puede concurrir directamente al duo 
dest de la reciprocidad fuerte. Y no se trata sólo de la imposibilidad de establecer la reciprocidad de una comunidad que no está, sino también de la imposibilidad de castigar los incumplimientos y las asimetrías, que es otro estímulo importante para la cooperación, como demuestran los resultados del juego del ultimátum, donde los jugadores están dispuestos a sacrificar todas sus ganancias con tal de penalizar a aquel que ha realizado una oferta de reparto que consideran deshonrosa por desigual e injusta (Thöni y Gächter, 2012). Todo parece, pues, concurrir contra la presencia de los intereses de las generaciones futuras en las decisiones democráticas de las generaciones actuales.

Pero si la «reciprocidad fuerte» hubiese sido el único mecanismo de motivación de las conductas altruistas y cooperativas, nuestra especie no hubiese sido viable (Tidball, 2012). El proceso de selección natural que opera en nuestras conductas cooperativas es un proceso de selección de multinivel (Allen et al., 2013). Entre los distintos mecanismos de selección y motivación cooperativa, se encuentra también la denominada selección de grupo, por la cual el individuo es capaz de sacrificar sus intereses estrictamente particulares o egoístas en beneficio del progreso o del interés colectivo (Sober y Wilson, 2000).

La topofilia pertenece al conglomerado de estímulos que refuerzan la selección de grupos, al establecer una asociación afectiva entre el territorio y el individuo. Un territorio que es representado como el hogar y el lugar del grupo (la comunidad). De esta forma, el individuo y la comunidad adquieren el compromiso y la obligación de conservar el lugar y el hogar colectivo, que es representado como un legado de las generaciones anteriores que debe ser transferido sin dañar a las generaciones venideras. Estas obligaciones convierten en aceptable a un conjunto variado de restricciones que afectan a las ambiciones $\mathrm{y}$ a los intereses, tanto individuales como generacionales, sobre el uso y el abuso de los recursos disponibles.

La «seguridad y la continuidad ontológica» que la topofilia posibilita, al religar al individuo con una comunidad histórica y natural concreta, permite que emerja una propiedad que reduce las conductas egoístas competitivas que están conectadas usualmente a situaciones de alto riesgo e inseguridad. Los entornos muy competitivos necesitan de situaciones de aislamiento y desenraizamiento donde el individuo perciba horizontes de escasez. Sennett (2000) ha descrito muy bien estas situaciones psicosociales óptimas para el desarrollo del individualismo egoísta.

De esta manera, el «descuento intertemporal» necesario para que los costes diferidos a las generaciones futuras sean percibidos como propios por la generaciones presentes se expresan en clave simbólica y afectiva por medio de erosiones en los sentimientos topofílicos e identitarios. Podemos percibir el daño en el futuro viendo el daño del paisaje en el presente que otorga identidad a nuestra comunidad.

Por último, la topofilia, al favorecer los sentimientos de pertenencia a una comunidad histórica y natural, refuerza las expectativas de interacción en el futuro, lo cual constituye un estímulo poderoso para el establecimiento de conductas cooperativas, en especial, con las generaciones futuras (Axelrod, 
1996). Tal como ha mostrado la teoría evolutiva de juegos, los individuos son más proclives a desarrollar estrategias de cooperación cuando tienen expectativas de repetir relaciones con otros individuos que cuando esas expectativas son estrictamente inmediatas (Sebanz, 2007). El sentimiento de pertenencia a un territorio y a una comunidad que la topofilia favorece, fomenta horizontes futuros y reiterados de interacción con los demás miembros de la comunidad presentes o futuros (Trivers, 1971).

La topofilia no sólo propicia sentimientos de solidaridad intergeneracional, sino que, al integrar el medio físico (territorio) en el horizonte simbólico e identitario (paisaje), refuerza también los sentimientos de solidaridad interespecífica con otras formas de vida animal y con los ecosistemas. De esta manera, la «comunidad silenciosa», que es la comunidad biótica, cobra subjetividad política por medio de la objetividad emocional que evoca el paisaje.

Pero la topofilia no está exenta de riesgos ni de perversiones. Una visión dialéctica y compleja de la misma ha de tomar en consideración también los efectos indeseables que pueden venir asociados a ella. Entre estos efectos indeseables, se encuentran el fomento del tribalismo y la competitividad entre grupos. En un mundo globalizado donde las amenazas sociales y ecológicas tienen, cada vez más, una dimensión planetaria, las alternativas requieren de la cooperación internacional. Y la topofilia puede ser un contraestímulo para que esa conciencia planetaria necesaria y esa acción internacional se desarrollen.

A estos efectos indeseables de la topofilia, hay que añadir la tradicional desconfianza que provocan las emociones o las pasiones sociales en el pensamiento político y social moderno (Maíz, 2010). Las emociones políticas son vistas como una fuente de irracionalidad en las decisiones colectivas y como un estímulo propicio para el autoritarismo y la manipulación de masas.

Por eso entendemos que, sobre la base de la asunción de los sentimientos topofílicos, es necesario que estos sean asumidos en un marco reflexivo y crítico orientado hacia la sostenibilidad ecológica y social. Es decir, el marco cognitivo dominante donde ha de ser insertada la topofilia debe ser el ecológico, no los marcos románticos nacionalistas o los marcos míticos y religiosos. Y es esta recuperación y reinterpretación ecológica, reflexiva y critica de los sentimientos y de las emociones la que puede desempeñar un papel relevante en la economía moral de la sostenibilidad (Wilson, 1999).

Las estrategias de conservación ecológica del paisaje y su valoración biofísica y simbólica pueden ser un buen escenario de concurrencia y transición entre las emociones básicas de la topofilia y los sentimientos ecológicos de la topofilia. En el paisaje, se ven significados tanto los rastros topofílicos de la memoria colectiva y la pertenencia, como los signos ecológicos de la degradación y la explotación industrial y consumista. 


\section{Conclusiones}

El paisaje representa el horizonte de objetivación de los sentimientos y las emociones de amor al territorio en el que se ha nacido y se ha vivido y del que se cree formar parte. A estos sentimientos, se les denomina topofilia. Los sentimientos y las emociones topofílicos responden a dos funciones evolutivas básicas que aportan ventajas competitivas en los procesos de selección natural:

a) Fijar las poblaciones a los territorios y evitar la concentración demográfica.

b) Establecer lazos de solidaridad y cooperación con las generaciones futuras.

Ambas funciones son reinterpretables y reutilizables a la luz de la crisis ecológica y de los déficits cognitivos y afectivos que la democracia padece para tomar decisiones en las que estén presentes las generaciones futuras (comunidad ausente) y la comunidad biótica (comunidad silenciosa).

A estos sentimientos interpretados y orientados bajo los marcos cognitivos de la ecología y la sostenibilidad, les llamamos topofilia La topofilia, al estimular las conductas de conservación del entorno, de distribución eficiente de la población sobre el territorio, y al establecer lazos afectivos con las generaciones futuras y la comunidad biótica, nos ayuda a minimizar el riesgo de incurrir en el «despotismo generacional» y en el «despotismo de especie».

La valorización estética, social y ecológica de la conservación del paisaje fomenta sentimientos y conductas individuales y colectivas que pueden ser, en esta hora contemporánea de la crisis ambiental, de una gran utilidad en la conformación de una economía moral ecológica, algo de lo que la ética ecológica está muy necesitada, henchida como se encuentra de principios y de normas.

\section{Referencias bibliográficas}

Allegrini, P.; Giuntoli, M.; Grigolini, P. y West, B. J. (2004). «From knowledge, knowability and the search for objective randomness to a new vision of complexity». Chaos, Solitons and Fractals [en línea], 20, 11-32. <http://dx.doi.org/10.1016/s0960-0779(03)00424-7>

Allen, B.; NowaK, M. A, y Wilson, E. O. (2013). «Limitations of inclusive fitness». PNAS [en línea], 1-5. $<$ http://dx.doi.org/10.1073/pnas.1317588110>

AXELrod, R. (1996). La evolución de la cooperación: El dilema del prisionero y la teoría de juegos. Madrid: Alianza Editorial.

- (2011). "Launching "The Evolution of Cooperation"». Journal of Theoretical Biology [en línea], 299, 21-24. <http://dx.doi.org/10.1016/j.jtbi.2011.04.015>

Barkow, J.; Cosmide, H. L. y Toовy, J. (comp.) (1992). The Adapted Mind: Evolucionary psychology and the Generation culture. Nueva York: Oxford University Press. 
Borgerhoff Mulder, M. et al. (2009). «Intergenerational Wealth Transmission and the Dynamics of Inequality in Small-Scale Societies». Science [en línea], 326, 682-688. $<$ http://dx.doi.org/10.1126/science.1178336>

Daly, M. y Wilson, M. (2005). "Carpe diem: Adaptation and devaluing the future». The Quarterly Review of Biology [en línea], 80 (1), 55-60. <http://dx.doi.org/10.1086/431025>

Dutton, D. (2010). El instinto del arte. Barcelona: Paidós.

Elster, J. (1981). Domar la suerte. Barcelona: Paidós.

Ferr, E. y Simon, G. (2002). «Altruistic Punishment in Humans». Nature [en línea], 415, 137-140. $<$ http://dx.doi.org/10.1038/415137a>

Garrido, F. (2009). «El decrecimiento y la soberanía popular como procedimiento». Respública, 441-447.

- (2012). «Republicanismo y ecología política». Sequência, 64, 15-38.

Gintis, H. (2003). «The Hitchhiker's Guide to Altruism: Genes, Culture, and the internalization of norms». Journal of Theoretical Biology [en línea], 220, 407-418. $<$ http://dx.doi.org/10.1006/jtbi.2003.3104>

González, M. y Toledo, V. (2011). Metabolismo, naturaleza e historia. Barcelona: Icaria.

Harvey, D. (2006). Spaces of Global Capitalism: A Theory of Uneven Geographical Development. Nueva York: Verso.

Lefebvre, H. (1986). La production de l'espace. París: Anthropos.

Linden, D. J. (2010). El cerebro accidental: La evolución de la mente y el origen de los sentimientos. Barcelona: Paidós.

Lindón, A. (2007). «El constructivismo geográfico y las aproximaciones cualitativas». Revista de Geografía Norte Grande, 37, 5-21.

Lotka, A. (1925). Elements of Physical Biology. Nueva York: Dover.

Maíz, R. (2010). «La hazaña de la razón: La exclusión fundacional de las emociones en la teoría política moderna». Revista de Estudios Políticos, 149, 11-45.

Mead, M. (1964). Continuities in Cultural Evolution. Nueva Jersey: Transaction Publishers.

Mostafavi, M. y Najle C. (2004). Landscape Urbanism: A Manual for the Machinic Landscape. Nueva York: AA Publications.

NovaK, M. A. (2006). «Five rules for the evolution of cooperation». Science [en línea], 314, 1560-1563. <http://dx.doi.org/10.1126/science.1133755>

Orians, G. H. y Heerwage, J. H. (1992). «Evolved Responses to Landscapes». En: Barkow, J. H.; Cosmides, L. y Tooby, J. (eds.) (1992). The adapted mind: Evolutionary psychology and the generation of culture. Nueva York: Oxford University Press, 555-579.

Ploeg, J. D. van der (2010). Nuevos campesinos, campesinos e imperios alimentarios. Barcelona: Icaria. 
Sebanz, N. (2007). «La psicología de la cooperación». Mente y Cerebro, 24, 58-63.

Sennett, R. (2000). La corrosión del carácter. Barcelona: Anagrama.

Sober, E. y Wilson, D. S. (2000). Unto Others: The evolution and Psychology of Unselfish Behavior. Londres: Harvard University Press.

Thompson, E. P. (1989). La formación de la clase obrera en Inglaterra. Barcelona: Crítica.

Thöni, C. y Gächter, S. (2012). «Peer Effects and Social Preferences in voluntary cooperation». IZA Discussion Papers, 6277.

Tidball, K. G. (2012). «Urgent biophilia: Human-nature interactions and biological attractions in disaster resilience». Ecology and Society [en línea], $17(2), 5$. <http://dx.doi.org/10.5751/ES-04596-170205>

Toledo, V. y Barrera-Basols, N. (2008). La memoria biocultural de la especie. Barcelona: Icaria.

Trivers, R. L. (1971). «The evolution of reciprocal altruism». Quarterly Review of Biology [en línea], 46, 35-57. <http://dx.doi.org/10.1086/406755>

Tyrtania, L. (2009). Evolución y sociedad: Termodinámica de la supervivencia para una sociedad a escala humana. México: Universidad Nacional Metropolitana.

Wilson, E. O. (1999). Resiliencia. Madrid: Galaxia Gutemberg.

YI-Fu, T. (1974). Topophilia: A study of environmental perception, attitudes, and values. Nueva York: Kindle.

- (1980). «Rootedness versus Sense of Place». Landscape, 24, 3-8.

Francisco Garrido Peña (Sevilla, 1958) es profesor titular de universidad del área de Filosofía Moral en la Universidad de Jaén. Es también responsable del grupo de investigación Biopolíticas (SEJ-348) y miembro de la Comisión de Éticas de la Universidad. Sus líneas prioritarias de investigación son la ética experimental, el diseño institucional, la bioética, y la ecología política.

Francisco Garrido Peña (Sevilla, 1958) is Senior Lecturer in Moral Philosophy at the Universidad de Jaén. He is the director of the Biopolíticas (SEJ-348) research group, as well as a member of the Ethics Comission of the University. His main research interests are experimental ethics, institutional design, bioethics and political ecology. 



\title{
Ecología, estética de la naturaleza y paisajes humanizados*
}

\author{
Fernando Arribas Herguedas \\ Universidad Rey Juan Carlos \\ fernando.arribas@urjc.es
}

\section{Resumen}

El denominado modelo natural ambiental de Allen Carlson sostiene que el valor estético de la naturaleza disminuye a medida que se acrecienta la intensidad de las intervenciones humanas en el entorno. Asimismo, Carlson argumenta que es necesario profundizar en el conocimiento científico de los objetos o de los paisajes para lograr una apreciación estética "correcta» de la naturaleza. Sin embargo, estas premisas no son tenidas en cuenta a la hora de establecer principios para una adecuada apreciación estética de entornos humanizados tales como los paisajes agrícolas, lo que resta coherencia al modelo natural ambiental. En el presente artículo, se examina esta contradicción y se esboza una concepción pluralista de la apreciación estética de la naturaleza que trata de congeniar criterios científicos, éticos y estéticos.

Palabras clave: ecología; estética; paisaje; modelo natural ambiental; Allen Carlson.

\section{Abstract. Ecology, Aesthetics of Nature, and Humanized Landscapes}

Allen Carlson's so-called 'natural environmental model' maintains that the aesthetic value of nature diminishes as the intensity of human intervention in the environment grows. Moreover, Carlson argues that more in-depth scientific knowledge of natural objects or environments is required in order to obtain a 'correct' aesthetic appreciation of nature. Nonetheless, these premises are not considered to establish principles for an appropriate aesthetic appreciation of humanized environments such as agricultural landscapes, and hence the natural environmental model loses coherence. In this article, this contradiction is examined and a pluralist conception of the aesthetic appreciation of nature is outlined to integrate scientific, ethical, and aesthetical criteria.

Keywords: ecology; aesthetics; landscape; natural environmental model; Allen Carlson.

\footnotetext{
* Este artículo se enmarca en el proyecto de investigación HAR2011-23678, Arte y ecología:
} Estrategias de protección del medio natural y recuperación de territorios degradados. 


\begin{aligned} & \multicolumn{2}{c}{ Sumario } \\ & 1. Introducción 4. Criterios plurales para apreciar \\ & 2. La apreciación estética de estéticamente la naturaleza \\ & la naturaleza según el modelo y los entornos humanizados \\ & natural ambiental de Allen Carlson Referencias bibliográficas \end{aligned}

3. La apreciación estética de los entornos humanizados

\section{Introducción}

Mes de julio en Castilla. Al atardecer, sobre los campos de cereal recién cosechados, la paja se extiende en sinuosos regueros realzados por la luz del sol que declina. Mientras tanto, el viento mece las espigas de los trigales aún no segados y forma olas que suenan a espuma efervescente en un mar imaginario. Más abajo, junto al río, los rayos del sol se cuelan entre chopos plantados en línea, evocando el interior de una enorme catedral en la que el viento agita las hojas de los árboles y hace crujir sus ramas.

Estos paisajes, a los que indudablemente concedemos valor estético, ¿pueden ser considerados «naturales»? Es evidente que la luz del sol, el cereal, la paja, los árboles o el viento no son objetos artificiales. Sin embargo, su disposición ordenada es un producto del designio humano, tal y como atestiguan los regueros de paja o los chopos alineados. Además, son entornos en los que subyacen problemas ecológicos a menudo imperceptibles de forma inmediata. Así, en los cultivos de cereal el uso intensivo de maquinaria y fertilizantes amenaza a la fauna que los habita, mientras que las plantaciones de chopo empobrecen el suelo fértil de las vegas de los ríos y desplazan a especies autóctonas también dignas de apreciación. Por tanto, cuando valoramos estéticamente un paisaje, el valor estético y el valor ecológico no parecen coincidir siempre. Ni siquiera estamos seguros de si lo que apreciamos es un entorno que cabe definir como «natural».

Muchas preguntas surgen a partir de una reflexión sobre estos ejemplos, pero aquí solamente nos interesa interrogar por el modo adecuado o correcto de apreciar estéticamente las diferentes clases de entornos, así como la relación entre la apreciación estética y la dimensión ecológica del paisaje. De ello se desprenderán algunas conclusiones relevantes para la consideración moral de tales entornos y los seres que los habitan. Así pues, algunas cuestiones fundamentales serían: ¿cuáles son los criterios que debemos emplear para juzgar estéticamente un paisaje? ¿En qué medida tales criterios están o deben estar determinados por otros criterios de valoración, como los proporcionados por el conocimiento científico o la ética? ¿Debemos apreciar solamente aquellos objetos y entornos ecológicamente equilibrados? ¿O, por el contrario, los criterios estéticos han de ser independientes y un paisaje ecológicamente deteriorado es también merecedor de apreciación? En definitiva, se trata de conocer 
el peso que los factores ecológicos y éticos tienen o deben tener a la hora de definir los criterios estéticos de apreciación de los entornos naturales y de los que sufren alguna clase de intervención humana.

Uno de los intentos teóricos que trata de responder a esta clase de cuestiones ha sido la denominada positive aesthetics. En general, este enfoque sostiene que el valor estético de la naturaleza es mayor en la medida en que no es alterada por la acción humana. Por tanto, el valor ecológico sería un factor decisivo para determinar el valor estético de los objetos y de los entornos naturales. La variante más sofisticada de este planteamiento es el denominado modelo natural ambiental de Allen Carlson, para quien la posibilidad de fundamentar una noción objetiva de lo estéticamente valioso ha de partir necesariamente del conocimiento científico de la naturaleza. En este trabajo se acepta, de acuerdo con Carlson, que el valor estético de los entornos naturales está determinado en gran medida por el desarrollo progresivo del conocimiento científico y de la conciencia moral ecológica, dimensiones que se refuerzan mutuamente. Así se explica que objetos y entornos que antes no merecían una valoración estética positiva sean ahora apreciados tras quedar constancia de su importancia ecológica. Es indudable que el conocimiento científico de la naturaleza alienta una educación de los sentidos que amplía el abanico de los objetos susceptibles de apreciación estética, lo que, a su vez, sirve de fundamento a las razones morales para conservarla (Matthews, 2002: 39). Sin embargo, debe asumirse que una buena parte de lo que consideramos apreciación estética de la naturaleza está influenciada por otros factores que no son las categorías de la ciencia ecológica. Existen categorías propiamente estéticas, así como aspectos intelectuales y emocionales que también poseen una gran relevancia, tal y como se pone de manifiesto al aproximarnos a la cuestión de la apreciación estética de objetos y entornos modificados por la acción humana. En este punto, como veremos, el modelo natural ambiental no ofrece una respuesta satisfactoria. Una concepción pluralista del valor estético de la naturaleza proporciona un marco más adecuado para comprender la importancia de los diferentes criterios que están en juego en lo concerniente a la apreciación estética de los entornos naturales y, más concretamente, de los entornos que, aun conservando gran parte de los rasgos que los definen como tales, vienen sufriendo una importante transformación debido a la intervención humana.

\section{La apreciación estética de la naturaleza según el modelo natural ambiental de Allen Carlson}

La positive aesthetics se ha esforzado por establecer principios objetivos para la apreciación artística de la naturaleza. Tales principios descansan en la determinación del valor estético en función del grado de intervención humana en el entorno físico. De este modo, la naturaleza virgen constituiría el modelo ideal, mientras que los paisajes profundamente modificados por la acción de las personas serían ejemplos de degradación del valor estético inherente a la naturaleza. Aunque esta concepción tiene sus orígenes en el siglo xvIII, han sido algunos 
pensadores ecologistas contemporáneos quienes la han formulado explícitamente. Así, se atribuyen a la naturaleza virgen propiedades positivas como integridad, belleza o capacidad de producir asombro y admiración (Leopold, 2000: 155) y se considera que todos los objetos, entornos y fenómenos físicos poseen cualidades intrínsecamente valiosas (Carlson, 2000: 72-74).

La defensa de este punto de vista muestra diversos grados de intensidad y se asocia frecuentemente a juicios éticos relativos a la bondad de lo natural frente a lo artificial. Sin embargo, conviene aclarar que no todo en la naturaleza virgen es bello o bueno por sí mismo. Catástrofes físicas como terremotos, erupciones volcánicas o incendios forestales destruyen la belleza natural y, además, causan sufrimiento a personas y animales. Por otro lado, los juicios negativos acerca de la acción humana sobre la naturaleza no deberían generalizarse. Pese a que las personas han mostrado una gran capacidad para destruir la naturaleza y generar fealdad, también han desarrollado el conocimiento suficiente para comprender las reglas del equilibrio ecosistémico y mejorar la calidad ecológica y estética de algunos entornos naturales que, con anterioridad, sufrieron un importante deterioro.

En este punto, es conveniente precisar el significado de la noción de «naturaleza», cuestión que no merece excesiva atención por parte de la positive aesthetics ni del modelo natural ambiental de Carlson y que es de especial importancia para elaborar una clasificación de las diferentes clases de paisajes a partir de criterios ecológicos. Se ha argumentado con frecuencia que el concepto de naturaleza y la distinción entre lo natural y lo artificial han perdido significado en nuestra época. Se aduce, además, que la especie humana también es un producto de la naturaleza, por lo que sus logros y acciones deberían ser igualmente considerados como algo «natural». La precipitada conclusión final de esta clase de argumentos es que la distinción entre lo natural y lo artificial ha oscurecido nuestra comprensión del mundo y de nosotros mismos durante siglos y lo continúa haciendo hoy día bajo la forma de «ecolatría» (Savater, 1996: 265-266). El problema de esta tesis es que confunde dos concepciones distintas del término "naturaleza»: por un lado, la noción de una naturaleza prístina, no modificada por el ser humano, que en ocasiones se postula además como criterio idealizado de valor estético y moral; por otro lado, lo natural como «lo que tiene lugar sin la intervención, o sin la voluntaria y deliberada intervención del hombre» (Mill, 1998: 29; Parsons, 2008: 2-3). En el primer caso, nos encontramos ante una noción sublimada de la naturaleza que, con frecuencia, ha hecho un flaco favor a la filosofía verde, puesto que, en el presente, no existe un solo ecosistema que no haya sido afectado por la actividad humana. Pero, en el segundo caso, lo que se describe como «natural» - $y$, por tanto, como algo que puede distinguirse de «lo artificial»— son todos aquellos hechos y procesos que tienen lugar sin que los seres humanos los propicien, tanto voluntaria como involuntariamente, tal y como reflejan las palabras de John Stuart Mill. Así, si se aceptasen las tesis de aquellos que no distinguen entre lo natural y lo artificial, habríamos de asumir que las centrales nucleares y los daños ecológicos que provocan son 
tan naturales como la luz del sol o que «el plástico es tan natural como la miel» (Savater, 1996: 245). Pero afirmar esto es algo profundamente contrario a la intuición más elemental. El devenir de las mareas, la formación de las nubes o la reproducción de las aves son fenómenos cuyo impulso motriz es por completo independiente de la intervención humana y, por tanto, se trata de procesos que claramente han de ser descritos como naturales. Sin embargo, incluso estos procesos están sufriendo hoy día los efectos de intervenciones humanas en el entorno. Pese a que, con frecuencia, se las describe como tales, gran parte de las consecuencias catastróficas del cambio climático difícilmente pueden considerarse como "fenómenos naturales», puesto que son transformaciones del medio que derivan de la acción de las personas. En este caso, estaríamos ante intervenciones humanas no deliberadas, ya que tales efectos nocivos no son buscados por sí mismos, pero sí son las consecuencias de uno o varios actos intencionados previos (por ejemplo: la quema de combustibles fósiles). Vemos, pues, cómo la idea de lo natural mantenida por Mill anticipa la noción de corrección ecológica y apunta a la conveniencia de preferir lo natural a lo artificial, es decir, esa acepción sustenta la necesidad de imitar los procesos naturales guiando nuestra conducta según los principios de la ecología, con el fin de garantizar la preservación de la vida y la civilización (Riechmann, 1997: 90-91; Riechmann, 2006: 188-212).

Por otra parte, pese a que lo natural y lo ecológicamente correcto o sostenible vienen a coincidir en la mayoría de casos, conviene advertir que, en ocasiones, el término «natural» se emplea para describir objetos y procesos no necesariamente correctos desde el punto de vista ecológico. Esta es la situación de aquéllos que han sido librados a su suerte tras intervenciones humanas ecológicamente nocivas. En tales casos, topamos con el dilema de la restauración ecológica: ¿es más natural «dejar hacer» a la evolución espontánea o intervenir para modificar su curso y permitir, así, que el ecosistema se reequilibre? No hay espacio aquí para discutir a fondo esta cuestión, pero es evidente que mantener el rigor conceptual sobre la distinción entre lo natural y lo artificial es fundamental para poder distinguir los entornos naturales de los que sufren alguna clase de intervención y poder reflexionar acerca de su valor ecológico y estético.

Así pues, se entiende aquí por entorno o paisaje natural aquel que no ha sufrido una intervención humana significativa a lo largo de un periodo considerable, de modo que está constituido íntegramente por objetos naturales, y son las fuerzas de los propios organismos las que determinan su devenir cotidiano ${ }^{1}$. Por otra parte, un entorno o paisaje humanizado es aquel en el que la intervención humana, aun siendo o habiendo sido considerable, ha dejado lugar a que los elementos físicos continúen determinando decisivamente tanto

1. Obviamente, fenómenos de alcance global producidos por la acción de las personas, como el cambio climático, tienen como consecuencia que la condición de "natural» ya no sea absoluta, puesto que los espacios más remotos y aislados de la presencia humana también sufren sus consecuencias. Pero ello no impide establecer una categoría como ésta, del mismo modo que la ausencia de un círculo perfecto en el mundo real no invalida el concepto de circularidad. 
su apariencia formal como los procesos ecológicos que en él se desarrollan. Ejemplos de entornos humanizados son los mencionados al inicio de este trabajo. Por último, un entorno o paisaje humano es aquel en el que la intervención de las personas ha alcanzado un grado tal que la naturaleza y los procesos naturales desempeñan un papel muy reducido ${ }^{2}$. Ejemplos de entornos humanos son los paisajes urbanos e industriales, los centros comerciales o las minas a cielo abierto. Indudablemente, los entornos naturales constituyen una parte cada vez menor de la superficie del globo a medida que los efectos de la intervención humana en el medio son más numerosos e intensos. No obstante, debe tenerse en cuenta que la distinción entre lo natural y lo artificial es una cuestión de grado y que, en algunos casos, resultará complicado establecer de un modo definitivo el carácter específico de un paisaje.

Una vez que se ha precisado la validez del concepto de naturaleza y la noción de entorno o paisaje humanizado, hemos de retornar a nuestro examen de las tesis centrales del modelo natural ambiental de Allen Carlson. Ya se ha dicho que este enfoque tiene como fundamento último el conocimiento científico de la naturaleza (Carlson, 2000: 85 y s.). Según Carlson, la ciencia desempeña un papel decisivo para el desarrollo de la noción de lo sublime, que comenzó siendo una concepción del valor estético de la naturaleza basada en el asombro y el recogimiento que ésta suscita en el espíritu (Kant, 2007; Burke, 2009). Los distintos avances en disciplinas como la geografía, la biología, la geología y, más tarde, la ecología sirvieron para reformular la noción de lo sublime, orientando la atención hacia cuestiones clave como la conservación de especies y paisajes vírgenes. Al igual que Carlson, varios pensadores han puesto de relieve la importancia del conocimiento científico proporcionado por la ecología a la hora de revelar nuevas esferas de valoración (Leopold, 2000; Elliot, 1982; Rolston, 1995). La ciencia nos concede la posibilidad de conocer mejor el mundo natural y hallar nuevos ámbitos y objetos susceptibles de apreciación estética. Como afirma Rolston (1975: 101), «vemos belleza ahora donde no podíamos verla anteriormente», debido a que estamos reescribiendo nuestro conocimiento del mundo a la luz de conceptos proporcionados por la ecología, como las ideas de unidad, armonía, interdependencia o estabilidad. Carlson sostiene además que, del mismo modo que la correcta apreciación de las obras de arte requiere el empleo de las categorías de la crítica y la historia del arte, los objetos y entornos naturales precisan de un conocimiento suficiente acerca de lo que son y cómo deben contemplarse (Carlson, 2000: 102-125). En otras palabras, las categorías correctas para apreciar estéticamente el mundo natural solo pueden venir dadas por las ciencias de la naturaleza, dado que las cualidades estéticas de los objetos y de los entornos naturales dependen decisivamente de cómo los percibimos (Carlson, 2000: 88; Matthews, 2002: 39).

2. Debe tenerse en cuenta que, al igual que no existen entornos naturales vírgenes, tampoco hay entornos humanos en los que los procesos físicos hayan desaparecido por completo. Las catástrofes naturales (sequías, inundaciones, huracanes, etc.), que, a su vez, están influidas por la actividad humana, recuerdan al habitante del entorno urbano que la naturaleza existe a pesar de todo. 
Ahora bien, aun aceptando que la apreciación estética correcta del mundo natural está determinada por el conocimiento empírico que podamos obtener de él y que solo determinadas categorías del conocimiento nos facultan para percibir determinados rasgos de ese mundo, quedaría por demostrar cómo este argumento apoya la tesis de que la naturaleza es esencialmente valiosa desde el punto de vista estético y que la intervención o modificación provenientes de la mano humana le restan valor. Según Carlson, existe un paralelismo entre las cualidades que hacen el mundo más comprensible para nosotros y las que nos permiten apreciarlo como algo bueno estéticamente. Cualidades como «orden», "regularidad», "armonía», «equilibrio» o "tensión» las apreciamos estéticamente en la esfera del arte. Así pues, arte y ciencia parecen poseer una raíz y unos objetivos comunes, del mismo modo que la actividad científica es también una suerte de «esfuerzo estético» (Carlson, 2000: 93). Existe un proceso de creación implícito en la actividad científica mediante el cual las categorías para apreciar estéticamente la naturaleza son elaboradas tras haber «descubierto» los objetos y los entornos naturales. En suma, según Carlson, existe una íntima correlación entre el desarrollo de las ciencias naturales y la apreciación estética de la naturaleza. El primero ha permitido que objetos o entornos anteriormente desdeñados o ni siquiera merecedores de atención, como las montañas o las selvas, sean ahora estéticamente apreciados. Del mismo modo, las cualidades estéticas de seres vivos como reptiles o insectos han sido paulatinamente desveladas a medida que la biología ha proporcionado un mayor conocimiento de ellos. La ecología no es sino el estadio final en el afianzamiento de la positive aesthetics, pues la ciencia ecológica, paradigma del conocimiento científico transdisciplinario, permite abarcar múltiples visiones particulares del mundo poniendo el acento en las cualidades ya mencionadas de la unidad, la armonía y el equilibrio naturales.

\section{La apreciación estética de los entornos humanizados}

Cabría esperar que Carlson mantuviera la validez del criterio ecológico de apreciación estética para toda clase de entornos, con independencia del grado de intervención humana que hayan padecido. Sin embargo, el modelo natural ambiental propone principios diferentes para la correcta apreciación estética de los entornos naturales, los paisajes humanizados y los paisajes humanos. Así, Carlson ha elaborado una argumentación específica con el fin de valorar las cualidades estéticas de los paisajes agrícolas contemporáneos que se basa en la noción de «ajuste funcional», un controvertido concepto que no encaja con el paradigma ecológico postulado para los paisajes naturales. Tras describir los profundos cambios que han afectado a los entornos rurales como consecuencia de la intensificación y la industrialización de la producción agraria, Carlson reconoce que los paisajes rurales actuales son monótonos y afectan negativamente a la vitalidad, la estabilidad y la integridad del entorno. Afirma, además, que es lógico sentir una cierta añoranza de los antiguos ecosistemas agrarios (Carlson, 2000: 183). Una razón de peso para reivindicar la protección de los 
paisajes agrícolas tradicionales sería su menor impacto ambiental y su contribución a la conservación de la biodiversidad, pero Carlson va a abandonar el cognitivismo ecológico para sostener que lo que nos impide apreciar estéticamente los nuevos paisajes agrícolas es la falta de familiaridad con ellos. Para apoyar esta idea, Carlson recurre de nuevo a la analogía con el mundo del arte, aunque esta vez lo hace en un sentido muy diferente, pues aquí la historia natural y la ecología ya no desempeñan el papel de fundamentos principales del conocimiento en los que ha de basarse la apreciación estética "correcta». Carlson argumenta que, al igual que las obras cubistas y futuristas fueron incomprendidas en su tiempo debido a que se juzgaron a través de códigos estéticos desfasados, tendemos ahora a hacer lo mismo con los nuevos paisajes agrícolas. A su juicio, nuestra mirada y nuestra mentalidad han de madurar durante un tiempo de adaptación suficiente para que podamos apreciarlos en sus propios términos, sin compararlos con aquellos que han reemplazado. Tras detallar los aspectos formales más valiosos de los entornos agrícolas contemporáneos, así como de la maquinaria y los sistemas empleados para su explotación, Carlson afirma que hemos de ir más allá de las cualidades expresivas de estos paisajes para apreciarlos como "paisajes funcionales». Así, una valoración estética correcta requiere captar su naturaleza "diseñada y necesaria» (Carlson, 2000: 187), de modo que calibremos la ingeniosidad humana, la eficiencia y la economía que les son inherentes. Carlson (2000: 189) concluye que los entornos agrarios "contribuyen a potenciar los procesos biológicos de la vida" y "son necesarios para nuestra supervivencia», lo que es un signo inequívoco de su «seriedad» y su carácter inevitable. En suma, hemos de percibir su funcionalidad para poder apreciar correctamente sus cualidades estéticas, y son funcionales en la medida en que contribuyen eficazmente a conseguir el objetivo para el cual han sido diseñados, que no es otro que la producción económica a gran escala que posibilita la supervivencia de la especie humana.

Sorprende que Carlson abandone aquí el objetivismo ecológico tan sólidamente defendido en lo concerniente a la apreciación de los entornos naturales. No hay en esta argumentación una reflexión sobre el considerable impacto ecológico de la mecanización rural. Así, la intervención humana intencionada, lejos de ser el factor que impide una apreciación estética "correcta», se convierte en el principal criterio de valoración cuando se trata de apreciar los entornos agrícolas. Si estos entornos cumplen eficazmente con el objetivo para el cual fueron diseñados, entonces serán estéticamente valiosos, con independencia de su impacto ecológico. De este modo, la dimensión ética del modelo de Carlson parece quedar restringida a la conservación de lo que él considera - aunque sin definirlos con precisión - entornos naturales, puesto que diferentes clases de paisajes exigen, a su juicio, diferentes principios de apreciación estética. En otras palabras: sin resolver esta contradicción, se antoja complicado fundamentar, en la obra de Carlson, una estética coherente con la protección del paisaje en términos ecológicos, tal y como algunos autores han pretendido (Hettinger, 2005; Matthews, 2002), ya que los paisajes humanizados —aquellos que demandan en mayor medida protección con arreglo a criterios de sostenibilidad 
ecológica - quedan al albur de criterios de «ajuste funcional» que, en última instancia, son una derivación de un enfoque puramente productivista. El objetivo de la máxima productividad es incompatible con los criterios empleados para la apreciación estética de los entornos naturales, a saber: la armonía, la estabilidad y la integridad entendidas en clave de equilibrio ecológico. Y el objetivo de la «supervivencia» resulta igualmente engañoso y falaz, puesto que la adopción de métodos de agricultura intensiva, derrochadores de energía y orientados a la producción de carne antes que a la alimentación humana directa, amenaza la sostenibilidad a medio plazo de los ecosistemas agrícolas y, por ende, la capacidad de las sociedades humanas para perdurar en el tiempo. Otro problema añadido es que Carlson sustituye la posición objetivista basada en el enfoque ecológico por un subjetivismo que resalta el carácter contingente de la apreciación estética cuando manifiesta que la familiaridad progresiva con los paisajes agrícolas nos permitirá apreciarlos debidamente. Para que estos paisajes sean percibidos "por sí mismos", los sujetos han de "adaptarse» a ellos, lo que implica reconocer el papel central de la elaboración subjetiva de la experiencia estética y de la adopción de un nuevo lenguaje formalista. Estos aspectos no son los más relevantes en la apreciación estética de los entornos naturales, cuyo valor está en gran medida determinado por el aspecto ecológico, una clase de valor objetivamente fundado en las categorías del conocimiento científico y no en «la intensidad del color y la audacia de líneas» que, a gran escala, "producen paisajes de impresionante belleza formal» (Carlson, 2000: 185; Hettinger, 2005: 68).

Carlson no aclara por qué los paisajes humanizados, que conservan muchos rasgos de los entornos naturales, no merecen una apreciación estética basada en los mismos principios que éstos, y los intentos por minimizar la contradicción que ello conlleva no han resultado satisfactorios. Así, Ned Hettinger cree que estos problemas son fácilmente solubles si el concepto de ajuste funcional se interpreta en términos de sostenibilidad ecológica (Hettinger, 2005: 70). Según Hettinger, el propio Carlson ofrece ejemplos para mostrar que la funcionalidad solamente se alcanza si nos aproximamos a la sostenibilidad, pero el hecho es que su concepción de la apreciación estética de los paisajes agrícolas es irremediablemente contraria a la noción de sostenibilidad. También se aprecian contradicciones con respecto al tratamiento que Carlson dispensa a los entornos humanos (paisajes urbanos, industriales, etc.), para cuya correcta valoración el criterio empleado es el del ya mencionado «ajuste funcional» (2001). Aunque Carlson dice sostener un "enfoque ecológico", semejante punto de vista solamente se aplica a la apreciación de los entornos humanos en términos de una analogía estructural, sin que haya un análisis del impacto ambiental que las intervenciones conllevan. No obstante, Carlson defiende también un «sentido fuerte» de lo estético para los entornos humanos, según el cual la apreciación de los «valores de vida» expresados por el entorno resulta decisiva. Los valores de vida incluyen la evaluación ética del proceso de creación o modificación del paisaje, de modo que, en caso de conflicto entre valores morales y estéticos, habrían de prevalecer los primeros. El problema es que este 
criterio choca fácilmente con el del ajuste funcional y Carlson no esclarece cuál de los dos debe prevalecer en caso de conflicto. En definitiva, el hecho es que Carlson ha empleado tres clases diferentes de criterios para determinar cuál debe ser la apreciación correcta de los entornos naturales, agrícolas y humanos respectivamente, sin aclarar suficientemente los motivos para hacerlo; cuestión crucial si tenemos en cuenta que la crisis ecológica consiste, precisamente, en la transformación acelerada de los primeros en alguno de los otros y en el grave deterioro ambiental de los segundos. El criterio utilizado para apreciar los paisajes agrícolas es claramente contradictorio con el establecido para los entornos naturales, si se admite que los primeros son paisajes humanizados que conservan gran parte de sus características naturales. Y el empleado para los entornos humanos bascula entre el problemático concepto de «ajuste funcional» y la determinación del valor estético con arreglo a la corrección moral. Si la corrección moral fuese el criterio predominante, la adopción general de un enfoque ecológico implicaría que los entornos agrícolas y humanos deberían ser apreciados en virtud del impacto ecológico de las intervenciones de las personas y no con arreglo al criterio del ajuste funcional. La pregunta, entonces, es: ¿por qué los paisajes agrícolas — entornos que aquí consideramos paisajes humanizados - han de ser la excepción?

\section{Criterios plurales para apreciar estéticamente la naturaleza y los entornos humanizados}

Como acabamos de ver, el modelo natural ambiental no ofrece una respuesta clara a las complejas cuestiones relativas a la apreciación estética de los paisajes humanizados. ¿Por qué abandonar el criterio ecológico a la hora de determinar el valor estético en los paisajes agrícolas? Éstos constituyen el más claro ejemplo de los que aquí he denominado "paisajes humanizados»: entornos ampliamente intervenidos, por lo que no son paisajes naturales "puros», pero en los que los objetos y procesos naturales continúan representando el papel principal, por lo que tampoco encajan en la categoría de entornos humanos. En ellos, la actividad de las personas deja lugar al florecimiento de ciertas especies vegetales y animales, aunque se encuentren amenazados por ella. En otros términos, los paisajes humanizados son, en cierto sentido, paisajes «domesticados». Deben distinguirse de los entornos humanos porque, en éstos, los aspectos formales de la naturaleza apenas se advierten y el número de especies que pueden sobrevivir es escaso. Por el contrario, en los paisajes humanizados, la naturaleza sigue estando presente de manera decisiva, conformando el entorno, aunque lo haga de un modo forzado o manipulado. En ocasiones, tales paisajes no revelan a simple vista algunos efectos de la intervención humana: son lugares ecológicamente degradados, en los que el devenir de las fuerzas naturales ha ocultado las huellas de la degradación. Es precisamente en esta clase de paisajes, que tienden a ocupar la mayor parte de la superficie terrestre, en los que es más necesaria la convergencia de los criterios ecológicos y estéticos, dado el deterioro ambiental que padecen. 
Sin embargo, esta convergencia no resulta fácil, puesto que nos enfrentamos a un serio dilema. El dilema surge del hecho de que con frecuencia apreciamos estéticamente ciertos paisajes en los que la intervención humana y el consiguiente deterioro ecológico son significativos. Es evidente que los entornos humanizados pueden poseer valor estético si se contemplan a la luz de criterios formales o de otra índole. Pero si son apreciados según los principios del modelo natural ambiental se situarán en un escalón inferior ya que, según la positive aesthetics, la naturaleza posee valor estético en la medida en que permanece intocada. Carlson esquiva este problema abandonando el modelo y adoptando criterios funcionalistas y formales. Con ello, asume que la correcta apreciación estética de tales entornos ya no se deriva del adecuado conocimiento científico, tal y como establece en su tratamiento de los entornos naturales, y da cabida a otros criterios menos relevantes a la hora de apreciar estos últimos. Esto presupone la posibilidad de distinguir con rigor los paisajes "naturales» de los «humanizados», algo que en la práctica resulta complicado puesto que la frontera entre ambas clases de paisajes es cada vez más borrosa y cambiante. Por ejemplo, en el caso de los paisajes agrícolas, la intensidad de la intervención humana varía dependiendo de la época del año. Mientras el cereal crece, la maquinaria apenas interviene, lo que permite la cría de algunas especies de aves. Durante ese periodo, el paisaje agrícola es casi un paisaje natural. Sin embargo, con la llegada de la cosecha a principios del verano, muchos pollos de esas especies fallecen bajo las aspas de las cosechadoras. Esta es la cara oculta del proceso de la cosecha mecanizada, que, por lo demás, ofrece, como afirma Carlson, aspectos de una gran belleza formal. El paisaje de la cosecha es un paisaje fuertemente humanizado que dejará de serlo otra vez hasta la llegada del otoño. Pero lo importante es constatar que estamos ante un caso que ilustra el dilema anteriormente mencionado: solo los criterios científicos del modelo natural ambiental nos permitirán apreciar la belleza de las especies que son puestas al borde de la extinción por el uso de una maquinaria que, al mismo tiempo, crea una nueva clase de belleza formal.

Como hemos visto, este dilema obliga a revisar las tesis del modelo natural ambiental para dar cabida a otros criterios con el fin de determinar cuál es la apreciación estética correcta de los paisajes humanizados. Carlson elabora un enfoque pluralista, pero, al apartarse del modelo natural ambiental y proponer como alternativa el criterio del ajuste funcional, no advierte las consecuencias para la dimensión ética de dicho modelo. En otras palabras, el criterio del ajuste funcional, así como la apreciación de los rasgos formales de los nuevos paisajes agrícolas, desplaza la tesis central de la positive aesthetics relativa a la convicción de que lo ecológico es valioso estéticamente $\mathrm{y}$, por tanto, cuestiona el argumento de que tenemos razones estéticas para proteger la naturaleza que se añadirían a las razones morales proporcionadas por la ética ecológica.

Así pues, la tarea consiste en encontrar un conjunto de criterios para definir la correcta apreciación estética de los entornos naturales y humanizados que 
integren los aspectos ecológicos y formales en la mayor medida posible. Este desafío pluralista implica aceptar la idea de que algunos paisajes humanizados poseen una nueva clase de valor estético propiciado por la intervención humana. Así, en el caso de los paisajes agrícolas, ese nuevo valor estético viene dado por diversos elementos formales, algunos de los cuales se manifiestan durante el proceso antinatural de la siega. Reconocer la existencia de este valor estético (mediante el «acostumbramiento», como afirma Carlson) no debería ser obstáculo para admitir que la aparición de esa clase de valor también oculta consecuencias ecológicas nocivas y, por tanto, que desde el punto de vista del modelo natural ambiental resta la clase de valor estético que proporcionan los objetos naturales y que solo es correctamente apreciada cuando poseemos un conocimiento científico suficiente acerca de ellos ${ }^{3}$.

Como ya he dicho, la necesidad de un modelo pluralista para dar cabida a otros criterios que determinan la apreciación estética correcta de la naturaleza es reconocida por el propio Carlson (2000: 10). Algunos de esos criterios son la capacidad de ser conmovidos por ella (Carroll, 1993), la imaginación metafísica (Hepburn, 1996) o la experiencia comprometida del entorno (Berleant, 1992). Ninguno de ellos, como admite Carlson, es en principio incompatible con el modelo natural ambiental; tampoco excluyen la posibilidad de apreciar estéticamente los rasgos formales de los nuevos paisajes agrícolas. Sin embargo, el criterio del ajuste funcional con los fines que los humanos perseguimos no encaja en un enfoque pluralista, puesto que contradice los supuestos básicos del modelo natural ambiental defendido por el propio Carlson. Pues si bien es cierto que en los entornos agrícolas surgen nuevos aspectos formales estéticamente valiosos, también lo es que la mayor parte de su valor estético continúa procediendo de las cualidades y objetos propiamente naturales que aún poseen. La transformación del paisaje propiciada por la revolución agrícola no tiene precedentes históricos y, si la pretensión de definir una teoría objetiva de la apreciación estética de la naturaleza es una posibilidad filosóficamente coherente, habría que admitir que tales aspectos formales han restado y continúan restando más valor estético del que aportan. En otras palabras, la tarea de mantener los entornos agrícolas en un estado lo más natural posible implica contribuir a la preservación de sus valores estéticos naturales en perjuicio de los sobrevenidos por la intervención humana.

En suma, las razones por las que seguimos valorando estéticamente los entornos agrícolas son variadas. En primer lugar, aún poseen muchos elementos formales propios de los entornos naturales (luz, color, formas, sonidos,

3. Hay ejemplos muy interesantes de la conservación de especies en un entorno agrícola y de la preservación de su valor estético natural. Uno de ellos es la intervención humana necesaria para proteger la cría de ciertas especies de aves, como el aguilucho cenizo, mediante la localización y protección de los nidos, con el fin de evitar su destrucción por parte de las cosechadoras, tarea que algunas organizaciones naturalistas llevan desempeñando en España desde hace años. El ejemplo es fascinante porque muestra claramente la paradoja a la que nos enfrentamos: es necesaria más intervención humana artificial (basada en el conocimiento científico de la problemática de una especie) para preservar su valor natural. 
olores, etc.) que son modificados por la intervención humana y que tendemos a apreciar estéticamente a medida que nos acostumbramos a su nueva configuración. En segundo lugar, en tales entornos continúan existiendo objetos naturales y siguen desarrollándose procesos naturales que, sometidos a nuevas amenazas que conocemos gracias a las aportaciones de la ciencia, reclaman protección. En tercer lugar, apreciamos estéticamente los entornos humanizados porque "nos conmueven» de alguna forma. Los aspectos emocionales de la experiencia estética, aun pareciendo carecer de importancia dado su carácter aparentemente subjetivo, desempeñan un papel crucial, no solo a la hora de determinar la apreciación estética correcta, sino también a la hora de valorar el alcance ético de las transformaciones que sufren los entornos humanizados y de motivarnos para protegerlos. Los paisajes humanizados nos recuerdan, cuando sabemos lo suficiente acerca de la naturaleza que aún poseen, que un proceso de deterioro ecológico está teniendo lugar y que su valor puede desaparecer para siempre. El componente emocional de la apreciación estética nos permite advertir, además, que junto con ese valor desaparece también algo importante de nosotros mismos. Así, por ejemplo, el sonido del viento agitando las espigas, el color cambiante a medida que avanza la primavera o el efecto de la luz del atardecer derramándose sobre los campos recién segados continúan siendo experiencias estéticas "naturales», aunque sepamos que los campos han sido cultivados por la mano humana con un fin estrictamente económico y que las consecuencias ecológicas que ello acarrea no son deseables para el ecosistema en su conjunto. Pero preservar el valor estético de esas experiencias es una tarea que puede ir de la mano con los intentos de mejorar la condición ecológica del ecosistema. Esto puede entenderse mejor si imaginamos que, en el futuro, una técnica de manipulación genética permitirá el desarrollo de una variedad de chopo sin ramas ni hojas y de troncos perfectamente rectos. En este caso, tendría lugar un incremento del «ajuste funcional», aunque, al mismo tiempo, experimentaríamos una pérdida de valor estético que nos afectaría a nosotros mismos por no haber protegido el ecosistema anterior, más rico desde el punto de vista de la biodiversidad. Esta pérdida de valor en el plano personal (e incluso en el plano cultural) correría pareja con la «desnaturalización» de los chopos. En ese caso, ¿aprenderíamos, como afirma Carlson, a apreciar estéticamente las nuevas choperas sin ramas ni hojas? Aunque llegáramos a hacerlo, sentiríamos que habríamos dejado algo importante en el camino: no solo valor natural, en el sentido en el que Carlson establece la correcta apreciación estética de los paisajes naturales, sino incluso la capacidad de apreciar estéticamente la naturaleza o lo que quedara de ella. En otras palabras: el paisaje perdería cualidades estéticas en la medida en que se degradara su carácter natural, pero también nosotros, como humanos apreciadores de su valor estético, estaríamos perdiendo la disposición y la capacidad de ser conmovidos por la naturaleza. Así, a medida que los chopos dejaran de ser árboles para ser simples depósitos de madera, nosotros no solo sentiríamos una pérdida de valor estético, sino que también experimentaríamos una reducción de nuestro grado de humanidad 
(Barry, 1999: 101-102)4. Con su desaparición como árboles y, por tanto, como objetos naturales, se desvanecerían también profundas experiencias estéticas asociadas a ellos y nuestra capacidad de distinguir lo estéticamente "correcto" de lo que no lo es. No ser conscientes de este problema puede conducirnos al relativismo ético y estético, problema que Carlson combate decididamente con sus postulados cognitivistas cuando trata de establecer los fundamentos de la adecuada apreciación estética de la naturaleza, pero que ha desatendido al ocuparse de los paisajes humanizados.

\section{Referencias bibliográficas}

BARrY, B. (1999). «Sustainability and Intergenerational Justice». En: Dobson, A. (ed.) (1999). Fairness and Futurity: Essays on Environmental Sustainability and Social Justice. Oxford: Oxford University Press, 93-117.

Berleant, A. (1992). The Aesthetics of Environment. Filadelfia: Temple University Press.

Burke, E. (2009). A Philosophical Inquiry into the Origin of our Ideas of the Sublime and Beautiful. Oxford: Oxford University Press.

Carlson, A. (2000). Aesthetics and the Environment: The Appreciation of Nature, Art and Architecture. Londres: Routledge.

- (2001). «On Aesthetically Appreciating Human Environments». Philosophy and Geography [en línea], 4 (1), 9-24. <http://dx.doi.org/10.1080/10903770125625>

Carroll, N. (1993). «On Being Moved by Nature: Between Religion and Natural History». En: Kemal, S. y Gaskell, I. Landscape, Natural Beauty and the Arts [en línea]. Cambridge: Cambridge University Press, 244-266. $<$ http://dx.doi.org/10.1017/CBO9780511554605.012>

Elliot, R. (1982). «Faking Nature». Inquiry [en línea], 25, 81-93. $<$ http://dx.doi.org/10.1080/00201748208601955>

Hepburn, R. W. (1996). «Landscape and the Metaphysical Imagination». Environmental Values [en línea], 5, 191-204. $<$ http://dx.doi.org/10.3197/096327196776679320>

Hettinger, N. (2005). «Allen Carlson's Environmental Aesthetics and the Protection of the Environment». Environmental Ethics [en línea], 27, 57-76. <http://dx.doi.org/10.5840/enviroethics200527141>

Kant, I. (2007). Crítica del juicio. Madrid: Austral.

Leopold, A. (2000). Una ética de la tierra. Madrid: Los Libros de la Catarata.

4. Merece la pena recordar las palabras de Brian Barry (1999): «Quizás la gente del futuro pueda aprender a encontrar satisfacción en paisajes totalmente artificiales y en caminar sobre hierba artificial entre árboles de plástico mientras pájaros electrónicos cantan en lo alto. Pero no podemos por menos que creer que algo horrible les habría sucedido a los seres humanos si no echaran de menos la hierba real, los árboles y los pájaros» (traducción propia). 
Matthews, P. (2002). «Scientific Knowledge and the Aesthetic Appreciation of Nature». The Journal of Aesthetics and Art Criticism [en línea], 60 (1), $37-48$. <http://dx.doi.org/10.1111/1540-6245.00050>

MilL, J. S. (1998). La naturaleza. Madrid: Alianza.

Oelschlaeger, M. (1991). The Idea of Wilderness: From Prehistory to the Age of Ecology. New Haven y Londres: Yale University Press.

Parsons, G. (2008). Aesthetics and Nature. Londres: Continuum.

RiechmanN, J. (1997). «La industria de las manos y la nueva naturaleza: Sobre naturaleza y artificio en la era de la crisis ecológica global». Ecología Politica, 13, 87-106.

- (2006). Biomímesis: Ensayos sobre imitación de la naturaleza, ecosocialismo y autocontención. Madrid: Los Libros de la Catarata.

Rolston III, H. (1975). «Is there an Ecological Ethic?». Ethics [en línea], 85 (2), 93-109. <http://dx.doi.org/10.1086/291944>

- (1995). "Does Aesthetic Appreciation of Nature Need to be Science Based?». British Journal of Aesthetics [en línea], 35, 374-386. <http://dx.doi.org/10.1093/bjaesthetics/35.4.374>

- (1998). "Aesthetic Experience in Forests». Journal of Aesthetics and Art Criticism [en línea], 56, 157-166. $<$ http://dx.doi.org/10.2307/432254>

- (2002). «From Beauty to Duty: Aesthetics of Nature and Environmental Ethics». En: Carlson, A. y Lintott, S. (eds.) (2007). Nature, Aesthetics, and Environmentalism: From Beauty to Duty. Nueva York: Columbia University Press.

Ross, S. (2006). «Paradoxes and Puzzles: Appreciating Gardens and Urban Nature». Contemporary Aesthetics, 4.

Savater, F. (1996). Diccionario filosófico. Barcelona: Planeta.

Fernando Arribas Herguedas es licenciado en Sociología, doctor en Filosofía y profesor del Departamento de Historia e Instituciones Económicas y Filosofía Moral de la Universidad Rey Juan Carlos de Madrid. Autor de diversos trabajos sobre ética y filosofía política, reflexiona actualmente en torno a la relevancia de la apreciación estética de la naturaleza para la formación y el desarrollo de la conciencia ecológica.

Fernando Arribas Herguedas holds a degree in Sociology and a PhD in Philosophy, and is a Lecturer in the Department of Economic History and Institutions and Moral Philosophy at the Universidad Rey Juan Carlos of Madrid. Author of several works on ethics and political philosophy, his current work focuses on the relevance of the aesthetic appreciation of nature to the formation and development of an ecological conscience. 



\title{
Restraining permanent sovereignty over natural resources
}

\author{
Petra Gümplová \\ Institut für Politikwissenschaft \\ petra.guemplova@sowi.uni-giessen.de
}

Reception date: 13-1-2014

Acceptance date: 6-3-2014

\begin{abstract}
The paper examines the international law principle of the permanent sovereignty over natural resources from a critical perspective of its conflict with demands for global environmental protection and sustainability. It is argued that state framed resource sovereignty per se does not represent an obstacle in the path of greater global environmental justice. The principle is strongly justified as a distinct economic expression of post-war state sovereignty and the ramification of the universalization of such principles as decolonization, self-determination, territorial rights, and sovereign equality of states. It is instead the interpretation of sovereignty and the set of practices established in the name of permanent sovereignty over natural resources that undermine international environmental law - the extension of sovereign resource rights beyond state borders, the continuous priority of unrestricted resource rights and development rights over international standards for environmental protection and sustainable use of resources, and the failure to reinforce notions and principles, both conceptually and legally, that better correspond to the global nature and comprehensive demands of ecological systems. The paper argues that the plausibility of resource sovereignty depends on the interpretation of the concept of sovereignty and how it incorporates self-limiting standards in its exercise. A parallel is established between limiting resource sovereignty using environmental sustainability standards and ecological stewardship and human rights as a widely accepted constraint on the exercise of state power over the population.
\end{abstract}

Keywords: sovereignty; resources; international environmental law; human rights.

\section{Resumen. La limitación de la soberanía permanente sobre los recursos naturales}

El ensayo examina el principio jurídico internacional de soberanía permanente sobre los recursos naturales desde una perspectiva crítica y analiza su posible colisión con la demanda de sostenibilidad y de una protección del medio ambiente a escala global. Se viene defendiendo que una soberanía nacional sobre los recursos naturales no es obstáculo alguno para la consecución de una justicia ambiental global de mayor alcance. La norma es fuertemente justificada como una expresión económica distinta de la soberanía estatal de postguerra y como una ramificación de la universalización de principios como descolonización, autodeterminación, derechos territoriales y equidad de los estados en cuanto a su soberanía. Pero la interpretación de la soberanía y el aparato de prácticas establecidas en el nombre 
de la soberanía permanente sobre los recursos naturales menoscaba, más bien, la ley ambiental internacional, por ejemplo mediante la extensión de los derechos soberanos sobre los recursos más allá de las fronteras de los estados, o estableciendo una prioridad continuada del derecho a un recurso abierto y del derecho al desarrollo por encima de las normas internacionales de protección ambiental y del uso de recursos sostenibles, o contribuyendo al poco éxito en el refuerzo de nociones y principios, tanto conceptual como legalmente, que se correspondan mejor con la naturaleza global y las demandas comprehensivas de los sistemas ecológicos. El ensayo defiende que la plausibilidad de la soberanía sobre los recursos depende de la interpretación del concepto de soberanía y de la manera cómo incorpore normas autolimitadoras en el ejercicio de la misma. Se establece un paralelo entre limitar la soberanía sobre los recursos naturales mediante normas de sostenibilidad ambiental, y la vigilancia ecológica responsable y los derechos humanos como medidas limitadoras ampliamente aceptadas para regular el ejercicio del poder estatal sobre los ciudadanos.

Palabras clave: soberanía; recursos; ley internacional medioambiental; derechos humanos.

\author{
Summary \\ 1. Introduction \\ 3. Sovereignty, territory, and global justice \\ 2. The development of resource \\ sovereignty: territorial expansion \\ 4. International human rights law \\ and environmental law \\ and economization \\ Bibliographical references
}

\title{
1. Introduction
}

Permanent sovereignty over natural resources is a firmly established standard of international law that authorizes states to exercise exclusive jurisdiction over natural resources and all components of the natural environment within their national boundaries. Ever since its introduction into international law in the late 1950 s, this standard has been widely accepted by states and indigenous groups as an economic corollary of the fundamental right to self-determination. However, permanent sovereignty over natural resources has been contested, if not downright refuted, by environmentalists and seekers of global justice, who argue that national borders and state sovereignty obstruct the solutions for such pressing global issues as climate change, environmental degradation, resource depletion, world poverty and economic inequality.

In terms of ecological sustainability and environmental protection, statebased resource sovereignty appears to be especially questionable. Increasingly urbanized and globalized societies require an ever-growing number of resources: soil, water, sink for greenhouse gases and other waste etc. However, the capacity of the Earth's biophysical and ecological systems to support modern life worldwide is reaching its limit. The critical environmental threshold may have been passed already. A group of scientists led by Johann Rockström recently identified nine measurable planetary boundaries and 
showed that human beings had already surpassed three such boundaries: in greenhouse gas loading of the atmosphere, in nitrogen pollution, and in the loss of biological diversity (Rockström, 2012). ${ }^{1}$ It is beyond obvious that globalization, modernization, and development not observing responsible use and environmental protection will further undermine the capacity of life-supporting ecological systems to sustain themselves and hence provide ecosystem services for humans.

Claims to permanent, full, inalienable, or absolute rights of states to natural resources within their boundaries, as justified by the permanent sovereignty over natural resources, clearly undermine the global effort to safeguard the environment, if only because environmental systems operate without paying heed to the firmly entrenched and yet historically contingent territorial jurisdictions of sovereign states. How should resource sovereignty, underlain by principles of autonomy and self-determination, the bedrocks of the modern international system, be reconciled with these concerns? In light of today's pressing need for environmental protection, can resource sovereignty be justified at all? This paper argues that there are good reasons not to refuse state sovereignty as a framework for global environmental justice, or for other dimensions of global justice, for that matter. However, the viability of resource sovereignty, both in theory and in practice, depends on the very interpretation of the concept of sovereignty and the way it incorporates self-limiting standards in its exercise. A parallel already exists. Resource sovereignty can be limited by environmental sustainability and ecological stewardship standards in the same way that human rights constrain the exercise of state power over its citizens.

\section{The development of resource sovereignty: territorial expansion and economization}

Permanent sovereignty over natural resources emerged from post-war efforts to reinforce the sovereign equality of states and economic equity in the postcolonial international order. The original statement regarding this collective right is recorded in the United Nations Resolution Declaration on Permanent Sovereignty over Natural Resources adopted in 1962. This resolution declares that permanent sovereignty over natural wealth and resources is an inherent

1. The Earth's biophysical and ecological systems include climate change, rate of biodiversity loss, nitrogen cycle, phosphorus cycle, stratospheric ozone depletion, ocean acidification, intensive global freshwater use, changes in land use, atmospheric aerosol loading, and chemical pollution. According to Rockström, quantitative planetary boundaries are defined for each system as a threshold beyond which the systems move into a state in which they can no longer provide support for the social and economic development of human societies. For example, the suggested climate change boundary of 350 parts per million of carbon dioxide in the atmosphere aims to prevent crossing of the threshold beyond which a significant climate change will most likely occur (Rocsktröm, 2012; Folke, 2013). 
and overriding right of a state to control the use of its natural resources in its territory, thus protecting them against foreign infringement. ${ }^{2}$

Permanent sovereignty over natural resources was further confirmed and developed in a series of charters and resolutions dealing with human rights, international economic order, social progress, development, and the environment. The Human Rights Covenants from 1966, the Charter of Economic Rights and Duties of States (1974) and the Declaration on the Establishment of a New International Economic Order (1974) are the most important international law instruments through which resource sovereignty was affirmed erga omnes. ${ }^{3}$ As a result of these treaties and legal instruments, permanent sovereignty over natural resources legally protects the right of the states to unlimited control, free exploitation and disposal of natural resources in their territories, to choose their economic system without outside interference, and also to regulate and nationalize foreign investment.

While the standard of permanent sovereignty over natural resources is relatively unambiguous in its aim and origin in the decolonization process, it has been less clear what state prerogatives it authorizes and, more importantly, what practices cannot be justified in its name. When assessing the development of the set of practices established in the name of permanent sovereignty over natural resources, one general tendency becomes apparent which, as Nico Schrijver rightly argued, is towards extending the scope of rights and prerogatives justified by resource sovereignty, with significantly less attention being paid to the question of what duties are incumbent on states and what kinds of limits are imposed on them in the exercise of their sovereignty over natural resources (Schrijver, 1997: 306). Unfortunately, it is in the field of environmental sustainability and protection where the emphasis on limits and duties has not quite corresponded to the urgency of environmental issues.

From the perspective of the sustainability of global ecological systems, three problematic tendencies can be observed as critical in the process of the gradual establishment of the practice of resource sovereignty. First, economically motivated pressure has been exerted by states to extend sovereign resource rights beyond their borders. Starting in the 1960s, this pressure led to a significant expansion of sovereign territoriality into marine areas and to a lesser extent into airspace and hence to the broadening of the scope of the appropriation of resources that had previously been international. Today, permanent sovereignty over natural resources comprises claims to natural resources and wealth not only on the land within a territory, but also to terrestrial and marine natural resources - and all economic activities for their exploitation (Schrijver, 2010: 111).

The second parallel tendency is the continuous prevalence and priority of unrestricted resource rights and development rights over international standards

2. The resolution is available here: <http://www.un.org/ga/search/view_doc.asp?symbol=A/ RES/1803\%28XVII\%29>

3. In international law, erga omnes standards are the concern of all states regardless of their multilateral or bilateral agreements. All states have a legal interest in the protection of these standards; they are obligations for everyone. 
for environmental protection and the sustainable use of resources. Although the sustainable use of natural resources underlies concepts such as the right to development, human rights, and economic growth, there is clear anthropocentric and economic substance in the concept of sustainable development resulting from ongoing efforts to reinforce economic development in developing countries and reduce poverty and inequality. A retrospective look at UN conferences and declarations on the environment show that the international community is actually less and less specific when it comes to guidelines for the management and conservation of natural resources, while it increasingly emphasizes the view that environmental policy should not obstruct development policy. ${ }^{4}$ At the World Summit on Sustainable Development in Johannesburg in 2002, the principles of international environmental law and their role in the promotion of sustainable development were barely touched upon. Instead, strategies for poverty reduction, food production, consumption and production patterns and the need to safeguard natural resources for the sake of social and economic development were addressed (Schrijver, 2008: 82, 96).

Finally, there has been a failure to reinforce, either conceptually or legally, notions and principles that better correspond to global nature and the comprehensive demands of ecological systems. International law, for example, has not adopted any consistent framework for natural resource domains that are not subject to national jurisdiction but belong to the global community as a whole. These resources are sometimes referred to as 'global commons'. The climate, the atmosphere, outer space, and the high seas are obvious candidates for global commons located outside national borders. However, international law does not recognize the concept of global commons; and neither has it developed a consistent jurisdiction for these spaces. The so-called 'common heritage of humankind' regime, introduced to foster international cooperation for peaceful purposes and to share among all nations the benefits from the use of common resources from oceans, unfortunately remains conceptually underdeveloped and inconsistently applied. It has not provided a real environmental alternative to an essentially economic concept of permanent sovereignty over natural resources (Schrijver, 2010: 75-113).

The development of the international law of the sea in recent decades might serve as a telling example of all these trends. Until the second half of the twentieth century, territorial sovereignty was strictly limited to land within state boundaries. Maritime states could only claim a narrow belt of the sea about three nautical miles off the coast. The use of the rest of the oceans was regulated by a regime called freedom of the high seas. This traditional principle of international law defined the sea as common to all and prohibited statebased or private appropriation of its territory and resources. Ships could thus freely navigate the waters, and states could engage in trade and fishing. The

4. Three conferences are relevant: the UN Conference on the Human Environment in Stockholm, 1971, the Earth Summit in Rio de Janeiro, 1992, and the World Summit on Sustainable Development in Johannesburg, 2002. 
assumption was that the sea's resources are inexhaustible and that humans are unable to impair the quality of the marine environment.

The United Nations Convention on the Law of the Sea (UNCLOS) from 1982 substantially extended territorial sovereignty over maritime areas by dividing the sea into various legal zones measured from the coastal state's baseline. Territorial sea was extended to 12 nautical miles from the baseline, with the adjacent contiguous zone extended to 24 nautical miles. The Convention also introduced the so-called exclusive economic zone (EEZ) which extends as far as 200 nautical miles from the baseline, within which a coastal state does not enjoy complete territorial sovereignty (the state is obliged to respect freedom of navigation, for example). However, it does enjoy exclusive rights to the exploration, exploitation, management, and conservation of natural resources, both living (fisheries) and non-living (resources of the seabed and its subsoil).

It is important to note that the pressure to claim much wider marine territory was motivated by attempts to achieve equitable sharing of resources and reverse the legacy of the colonial economic order. This came from Latin American countries and newly independent African states who felt the need to halt the large-scale exploitation of what were supposedly 'their' fish stocks by foreign fishing fleets and oil by foreign oil companies. The classical freedom of the high seas implied open access to the sea and would have led to first-comefirst-served advantage for more economically powerful states. The continuation of this traditional standard would certainly have led to an unaccountable system of predatory economic power, unlimited exploitation of resources, and some forms of colonial competition among rich maritime nations. A new legal regime was thus necessary to define standards for the proper and sustainable management of marine resources, to protect the economic security of coastal states, and simultaneously to ensure that the sea is preserved for the benefit of all (Schrijver, 1997: 205, 228).

Therefore, parallel to the affirmation and reinforcement of sovereign resource rights to the sea, a new principle of resource management for nonsovereign maritime areas was introduced: the principle of the common heritage of mankind. ${ }^{5}$ Designed specifically for the use of maritime resources, ${ }^{6}$ this regime set standards and principles for the governance of non-sovereign areas and resources. The aim was to protect and manage common areas in the name of equity, preservation, and sharing by a global community. While resource

5. The size of the maritime area to which the common heritage principle applies has been significantly reduced by the establishment of 200 -mile EEZ and can be potentially further diminished by the possibility of the extension of the outer limits of EEZ up to 350 nautical miles. EEZs, claimed or claimable, now cover about $35 \%$ of the marine area and are estimated to include approximately $90 \%$ of the living resources under commercial exploitation, tuna and whales being the main exception (Schrijver, 1997: 228).

6. The principle was first formulated in the General Assembly Resolution from 1970 called the Declaration of Principles Governing the Sea-Bed and the Ocean Floor, and the Subsoil Thereof, Beyond the Limits of National Jurisdiction; then it was incorporated into UNCLOS. 
sovereignty protects exclusive national access to resources, common heritage of mankind is a form of resource management that prohibits sovereign or private appropriation. As opposed to exclusive appropriation, common international management, economic cooperation, the sharing of benefits from exploitation, the use of resources for peaceful purposes, freedom to engage in scientific research, and preservation for future generations are emphasized (Schrijver, 2010: 9).

However, the principle of the common heritage of humankind has not become a counterbalance to permanent sovereignty over natural resources, and especially to territorial expansion and the economization of resource management justified in its name. The principle of common heritage of humankind has only been applied to specific resources in the oceans, namely to the area of the deep seabed and the ocean floor and its subsoil. It remains unclear what the principle entails when it comes to these resources. With the recent discovery that the great ocean depths contain so-called 'polymetallic nodules' that are rich in valuable metals, and with ensuing attempts to examine and commercially exploit these resources, it is obvious that the seabed will not remain a completely decommercialized or scientific zone nor a resource preserved for future generations. ${ }^{7}$

The environmental and non-economic aspirations of the principle of the common heritage of humankind are being further undermined by the possibility of extending the exclusive economic zone even further than 200 nautical miles. The Arctic region is currently a battleground where states motivated by resource grab are competing for further territorial extension of their exclusive economic zones. Although scientific data on what lies under the Arctic Ocean is incomplete, mineral deposits in the Arctic seabed are estimated to hold 25\% of the world's current oil and natural gas reserves (Sonntag, Luth, 2011). Technological developments and the recent ice melt, which is said to have reduced sea ice by as much as $50 \%$, ignited territorial temptations and resource scramble among Arctic states that are now striving to extend their exclusive economic zones beyond the $100 \mathrm{~nm}$ limit. In this area, which unlike Antarctica lacks a specific international legal regime to protect it against commercial exploitation, ${ }^{8}$ further territorial expansion is in fact possible on the basis of the criteria for the delimitation of maritime zones set in UNCLOS.

7. As a matter of international law, all rights to these polymetallic nodules are vested in humankind as a whole. In practice, this means that the International Seabed Authority (ISA) issues contracts that authorize exploration and mining and collects and distributes royalties, taking into consideration the needs and interests of developing countries. So far, research is only being conducted by the governments of China, India, South Korea, France, Germany, and Russia (Schrijver, 2010: 76-78).

8. Antarctica is designated as an area that shall be used only for peaceful purposes, including scientific investigation. The Antarctic Treaty of 1959 declared Antarctica a special conservation area and froze states' existing claims to sovereignty. Furthermore, there is a 50 year moratorium on Antarctic mineral resource activities established through the adoption of the Protocol on Environmental Protection to the Antarctic Treaty in Madrid in 1991. 
These criteria allow states to further expand their exclusive economic zone to 350 nautical miles from the baseline or to 110 nautical miles from the 2,500 meter isobath, ${ }^{9}$ whichever is more favorable to the applicant State. The coastal state has to prove that there is a continental shelf attributable to it that reaches that far as a natural prolongation of its land territory. ${ }^{10}$ Countries such as Russia and Canada have devoted significant resources to measuring and mapping their extended continental shelves in order to establish resource sovereignty over the Arctic Ocean floor and its subsoil beyond their 200-mile exclusive economic zones. In August 2007, a Russian expedition placed a Russian flag on the seabed at the North Pole, claiming it as the utmost peak of its territory prolonged by submarine geological formations in its continental shelf.

As for the living resources of the high seas (fish stocks), these are not managed using the principle of the common heritage of mankind but through the principle of open access. In practice, this means that all states have the right to engage in fishing on the high seas on a first come, first served basis. As a result of this regulation, almost all living resources (fisheries) in the world's oceans were brought under commercial exploitation. Freedom of fishing is limited by UNCLOS provisions regarding the conservation and management of the living resources of the high seas. To avoid overexploitation, the state is obliged to maintain the population of harvested species at levels that can produce 'the maximum sustainable yield'. ${ }^{11}$

Nevertheless, the vast majority of exploited fish populations have been depleted to abundance levels well below those recommended by conventional management guidelines. According to several reports, most fish species are on a continuing trajectory of decline (Pikitch, 2012). The World Bank report of 2009 predicts that if current fishing rates continue, all the world's fisheries will have collapsed by the 2050s (The World Bank, 2009). Faced with the collapse of large-fish populations, commercial fleets are searching deeper in the ocean and farther down the food chain for viable catches. This 'fishing down' is triggering a chain reaction that is upsetting the delicate balance of the sea's biologic system. And yet, an ecosystem based approach with more precautionary management has not replaced traditional management of fisheries focused on obtaining the maximum sustainable yield for a single species of fish and ignoring the detrimental effects of fishing on the entire ecosystem.

9. Isobath is defined in bathymetry as the line connecting points at a depth of 2,500 meters below sea level.

10. UNCLOS provides an exception to this rule. If the continental shelf breaks into an oceanic ridge, it cannot be extended to more than $350 \mathrm{~nm}$ from the coast no matter where the 2,500 meter isobath falls. This issue lies at the heart of the Russian dispute over parts of the Arctic territory. Russia challenges the definition of the Lomonosov and Alpha-Mendeleev ridges as submarine ridges, claiming instead that they are natural geographical components of their continental shelf reaching to the North Pole (Sonntag, Luth, 2011).

11. Marine mammals are subject to a different management regime with stronger protection and conservation measures (Schrijver, 2010: 83-88). 
As the example of marine resources shows, the principle of common heritage of humankind (a potentially far-reaching principle applicable as a set of protective measures of ecological systems regardless of the lack of an overlap with the state territory) does not represent an environmental alternative to the regime of territorial sovereignty, which explicitly protects the right to economic appropriation and exploitation of resources. Its application to other candidates for global commons has also been ambiguous. ${ }^{12}$ For example, the atmosphere does not enjoy any special legal status or governance regime. Despite atmospheric resources sharing many features with natural resources in international areas, they are not global commons. When they are located above areas under the national jurisdiction of states and above exclusive economic zones, they are subject to the sovereignty of states. The remaining atmospheric resources are a common property, providing a completely free and open waste disposal system for a whole range of pollutants (Schrijver, 2010: 98). Only recently, the ozone layer and the climate system were vaguely declared a 'common concern of humankind' and their protection has become the subject of several protocols stipulating the necessary measures and control mechanisms for tackling ozone depletion and climate change. ${ }^{13}$

\section{Sovereignty, territory, and global justice}

Is the standard of permanent sovereignty over natural resources per se the obstacle to achieving greater global justice, environmental or other? I argue that the problem is not resource sovereignty itself. The key to responding to global issues is a proper understanding of the concept of sovereignty and the interpretation of resource sovereignty as being constituted by limits and duties, exactly like state sovereignty today is understood as being constituted and limited by human rights standards. Simultaneously, the reinforcement of the global regime for the management and protection of resources or ecological systems (both within sovereign territories and beyond them) must complement the reinterpretation of resource sovereignty.

12. For example, the non-appropriation of resources is not clearly articulated in any treaty or agreement regulating outer space and celestial bodies. The Moon Agreement from 1979, ratified by only 13 states (none of which are capable of space exploitation), stipulates that states have the right to exploration and use of the moon without discrimination of any kind and on an equal basis. Unlike UNCLOS, the agreement does not establish a specific institutional structure to govern the exploitation of these resources (Schrijver, 2010: 88-90).

13. The Montreal Protocol was adopted to reduce the emission of ozone-depleting substances. Unfortunately, the ratification of most recent amendments with stronger control measures has been seriously lagging despite the obvious fact that the gap in the Antarctic's ozone layer will persist longer than estimated. As regards climate change, the Kyoto Protocol from 1997 determines measures necessary for stabilizing atmospheric concentrations of greenhouse gases. Support and participation in the Protocol has been low; and ensuing conferences on climate change have not produced any binding commitments on further reduction of emissions (Schrijver, 2010: 101-110). 
The reasons not to dismiss permanent sovereignty over natural resources are of both a historical and conceptual nature. Resource sovereignty is unintelligible if one does not understand its political significance in the historical context. As the history of post-war international law shows, resource sovereignty originated in negotiations over the inequitable arrangements imposed on colonized nations during the colonial period. The exploitation and appropriation of resources by foreign companies and their insistence on the continuity of their contractual rights to exploit the resources in the new postcolonial era were among the most salient injustices that the new standard of resource sovereignty corrected. Contrary to the terms of foreign investment contracts from the colonial period, developing nations claimed rights of ownership of their resources, understood as a corollary of a more fundamental right to self-determination and independence. The utilization of a state's own natural resources protected by permanent sovereignty over natural resources was an essential prerequisite for economic development and the bulwark against predatory and imperial forms of economic power and economic domination, and hence the bedrock of political independence (Anghie, 2005; Sornarajah, 2010).

Permanent sovereignty over natural resources has therefore become a widely accepted principle of a new international order and an inherent element of post-war state sovereignty. From the conceptual perspective, the emergence of permanent sovereignty over natural resources marks a profound transmutation of the institution of state sovereignty in the twentieth century that went largely unnoticed by political theory. Permanent sovereignty over natural resources translates the principles inherent in the concept of sovereignty (independence, autonomy, non-intervention, and self-determination) into the economic sphere. It emphasizes territorially determined resource rights as an economic expression of state sovereignty. But how do we account for economic competences and prerogatives of sovereign states? Is there any continuity between the concept of economic sovereignty and political sovereignty in the discourse about the state and sovereignty in political theory? Can the notion of economic sovereignty be derived from the predominantly legal discourse about political authority and state power over persons? What is the normative conception of economic rights and competences of the state and their limits?

Unfortunately, modern discourse on sovereignty offers almost no clues for answering these questions and so it is no wonder that a theory of economic aspects of state sovereignty and territoriality is still missing from political theory. This is because political and legal discourse on sovereignty has, for the most part, identified the state with its constitutional form and focused on the juridical-political questions about the form, the location, and limits on political power. From this legalistic perspective, territory has appeared to have a merely functional meaning of spatial circumscription of a sphere of jurisdiction over a population located within geographic boundaries. The concept of permanent sovereignty over natural resources can thus hardly appear as a corollary of the traditional discourse about sovereignty framed as a problem of legality and 
legitimacy of political authority whose jurisdiction is thought to be directed primarily at persons.

A much younger framework of territorial rights and rights to self-determination to which resource sovereignty is connected historically might offer a starting point for an account of permanent sovereignty over natural resources. A theory of territorial rights, which includes the account of collective rights of the people over natural resources, is indeed the appropriate conceptual framework for understanding collective sovereign claims over resources. The theory of territorial rights emerged only very recently in response to several pressing issues, such as the need to find a resolution for territorial disputes or to respond to the claims to territory made by indigenous peoples (Ivison, 2002; Hendrix, 2008), and of course to the need to resolve the question of the claims to resources and their redistribution, domestically and globally (Beitz, 1990; Steiner, 1996; Pogge, 2002).

One of the distinct features of the theory of territorial rights is that it shifts attention from narrow juridical-political concern with the form, location, and limits on political power towards a more fundamental question of the moral justification of the existence of sovereign political authority and of rights, duties, and demands that belong to it. In this respect, theorists of territorial rights are reviving, explicitly or implicitly, the approach of early modern natural law thinkers who used to ask what justifies political authority and state sovereignty over particular populations and territories. Natural law thinkers assumed that both the sovereignty and territoriality of political authority play a vital role in implementing the conditions of justice. The territorial scope of sovereign political power had a broader meaning in this somewhat forgotten tradition of political thought insofar as the people's territorial rights (individual property rights and collective resource rights, for example) were conceived as a matter of pre-political natural law and justice. Sovereign rights to set positive laws were designed with the purpose of reinforcing and safeguarding this natural justice, which included not only peace and security, but also private property and the economic system (Locke, [1689] 1980). Later, the preoccupation with constitutionalism narrowed the discourse on sovereignty down to the question of the legality of sovereign political authority (Kelsen, [1934] 1970).

Some of the most recent approaches to the theory of territorial rights have been inspired by the link natural law theorists established between sovereignty, territoriality, and justice. Cara Nine, for example, offers a contemporary liberal-collectivist defense of territorially limited resource rights. Nine defends the view that the holder of territorial rights is a collective with the capacity to be politically self-determining and can establish justice within a particular geographical space through legislation and the adjudication and enforcement of laws regarding persons and natural resources. Recalling natural law tradition, she emphasizes that the justification for the claim made by a collective to be a territorial right holder comes from the paramount value of justice for the members of this collective.

Peace, security, and the protection of private property emphasized by early modern natural law thinkers are important parts of the implementation of the 
idea of justice. However, in order to implement justice in contemporary society, these basic human needs must, in Nine's view, be extended. Relying on new interdisciplinary research in social sciences combining psychology, ethics, moral philosophy, and social policy, ${ }^{14}$ Nine thus expands the notion of justice into a new paradigm of human well-being that depends not only on the rule of law but also material welfare and economic development. Consequently, territorial rights involve more than a legitimate claim to make, adjudicate, and enforce legal rules over persons within a territorial domain. As Nine shows, they also include jurisdictional rights over resources within the territory: the authority to determine property rights, to determine the management, withdrawal and alienation of natural resources etc. (Nine, 2012: 6-9).

Nine's theory helps to recast the territorial meaning of sovereignty in economic terms. Simultaneously, it offers a response to global justice theorists and cosmopolitans who refuse territorial sovereignty and the institution of territorially demarcated political authority as a means of implementing the conditions of justice (Beitz, 1990; Barry, 1991; Pogge, 2002; Caney, 2005). Critical examination of theories of global justice is beyond the scope of this paper. Suffice to say that regardless of the scope of justice (domestic or global), it necessarily presupposes the idea that a collective is entitled to goods or resources. Such an entitlement can be explained and justified only by a theory of territorial rights that addresses who is a legitimate holder of territorial rights, what these rights exactly involve, and what justifies such an exclusive territorial claim (Nine, 2012: 146).

While such a territorial claim can be global in scope, I believe that there are good reasons to maintain the framework of state sovereignty. For one reason, the state involves the correspondence between jurisdictional authority over a community of persons and rights over resources. These are two inseparable ways of establishing justice for members of a collective. While both these authorities can be theoretically be conceived as belonging to a global community, the sovereign territorial state remains the institution that involves a public, coercive and legitimate legal order, with direct effect on individuals, and creating distinct associative obligations and duties. Moreover, only within the framework of the sovereign territorial state are both authorities bound to conditions that make them politically legitimate in a relatively strong sense. Therefore, the goals of global justice are better achieved through limits that territorial collectives impose on themselves. The question is thus what limits need to be inserted in the conception of territorial rights that prevent collectivities (states) from assertively expanding their territorial rights, from engaging in controversial practices such as unlimited and environmentally harmful exploitation of natural resources or from economic exploitation or devastation of global commons.

14. For example, the "capabilities approach" popularized by Martha Nussbaum stresses that basic human needs are irreducible to mere physiological maintenance and extend to active social and political well-being that depends on what individuals are effectively able to be (Nussbaum, 2000). 
To conclude: permanent sovereignty over natural resources is a standard implied in the conception of collective territorial rights that emphasizes the inextricable link between political self-determination, autonomy, sovereignty and, independence on the one hand, and the autonomy to determine the social and economic system on the other. When accounted for in this framework, permanent sovereignty over natural resources is the economic corollary of state sovereignty, and of the principles of sovereign statehood universalized only after World War II: political self-determination, supremacy of domestic legal order, external independence, social and economic autonomy, sovereign equality and non-intervention. (Cohen, 2012: 200). The task is to avoid the interpretation of resource sovereignty in terms of permanent, absolute, inalienable, full sovereignty and to interpret it in terms of self-limiting standards that restrain its exercise.

\section{International human rights law and environmental law}

In the final section of the paper, I would like to discuss the possibility of restraining resource sovereignty using environmental ethics and sustainable development standards. To assert the idea of constitutive self-limiting standards in the exercise of sovereignty, I suggest we explore and use human rights discourse as a model for the de-absolutization of sovereign resource rights. First, I shall briefly summarize the impact of human rights, both as a discourse and practice, on the institution of state sovereignty.

Sovereignty emerged in early modern political thought as a concept of a supreme political power that has the sole authority to create law. To highlight this novel, quintessentially modern concept of the supreme political authority and its unity with law enactment and enforcement, early modern political thinkers (Hobbes in particular) characterized sovereignty in terms of the unity, indivisibility, unconditionality, and unlimitedness of the absolute power unbound by the covenant that institutes it (Hobbes, [1651] 1985). Based on the first modern theories of sovereignty, the concept of sovereignty has been generally interpreted as involving the following tenets: 1 ) the idea that sovereignty is located in a single and unitary organ of the state or is embodied in a person; 2) the idea that the coherence and unity of a legal system have to be traceable back to the will of the sovereign, who is legibus solutus, i.e. above the law; 3) the view that law ought to be obeyed merely because it is the sovereign's command; and 4) the view that sovereignty is linked to a specific set of prerogatives that also include the jus belli (right to war) which renders sovereignty incompatible with international law.

It is beyond the scope of this paper to ask whether this is the right interpretation of the original concept of sovereignty. ${ }^{15}$ The fact remains that until

15. I argue elsewhere that this interpretation does not do justice to the essence of the concept of sovereignty and that constitutionalism is the original discourse about sovereignty (Gümplová, 2011). 
World War II, sovereignty was understood as a political fact of absolute and impermeable state power existing independent from and prior to international law. In the second half of the $20^{\text {th }}$ century, a momentous transformation had a serious impact on the concept of sovereignty and the practice of sovereign statehood. On one hand, there was an unprecedented effort to regulate the use of military force and install a global security regime. Contemporary sovereign states no longer have the right to go to war and to annex or colonize foreign territories. On the other hand, the prerogatives of sovereign states in the domestic sphere have changed under the impact of international laws on human rights. ${ }^{16}$

The international human rights regime has developed steadily since 1948 through multilateral treaty making, domestic state practice, and the work of international courts and other actors. Dozens of human rights treaties are now in effect due to organizations such as the United Nations, the Council of Europe, the Organization of American States, and the African Union. Some of these treaties have been ratified by more than three-quarters of the world's countries. The main source of the contemporary conception of human rights is still the Universal Declaration of Human Rights (UDHR) adopted in 1948, which indicates rights such as that to live, freedom from torture, freedom from slavery, right to a fair trial, freedom of speech, freedom of thought, conscience and religion, freedom of movement, and the right to engage in political activity as universal rights for all peoples irrespective of their nationality or political allegiance. The reaffirmation of these rights in numerous international covenants and resolutions and the incorporation of these rights in national constitutions have made human rights articulated under terms of the UDHR almost universally accepted standards for human well-being and political allegiance (Beitz, 2011).

As human rights theorists of all proveniences agree, human rights protect the basic rights of all individuals by virtue of being human. They are universal, i.e. they are valid and binding on all individuals and societies whatever their religion, tradition, or culture. An important feature of human rights is that they are meant to protect the essential and universal features of human personhood against the state. ${ }^{17}$ As Jean Cohen emphasized, human rights are thus 'associational' rights, activated by the presence of and membership of specific socio-political institutions. As such, they impose constraints on these institu-

16. There are countless accounts of how the post-World War II international legal order based on the sovereign equality of states and international law based on consent is being complemented by a new system of geo-governance by the international community and intergovernmental networks addressing issues of human rights and security (Teitel, 2011; Sikkink, 2011; Fox, 2008).

17. Dignity, freedom, and equality are usually cited as the most fundamental moral features of personhood. There are a number of approaches to human rights; and they differ not just in how they provide general justification of human rights, but also in explaining what essential and universal features of human beings must be protected by human rights agency, personhood, basic interests, capabilities, autonomy, and dignity. For an overview, see Donnelly (2013: 7-21). 
tions and on those acting in their name. They function as standards for state governments such that their violation or non-fulfillment is justification for remedial action by the global community. International human rights thus indicate that the way a state treats its own citizens is a matter of international concern (Cohen, 2012: 182).

Many cosmopolitan thinkers and legal theorists argue that today, the state sovereignty and legitimacy of governments should be considered contingent on their being both non-aggressive externally and, more importantly, minimally just internally, i.e. respectful of human rights (Macdonald, Johnston, 2005; Klabbers et al., 2009). Although there are 'statist' thinkers who insist that international law still is and should remain protective of state sovereignty, domestic autonomy, and non-intervention, a profound transformation is indeed occurring. Under the impact of human rights and collective security standards, there has been a shift from the classic statist interpretation of sovereignty as independence, non-intervention, and impunity to the interpretation of sovereignty as justice and security for individuals and citizens of a given state, and hence responsibility and accountability to the international community and potentially also the liability of perpetrators (state officials or private entities) in terms of international sanctions (Cohen, 2012: 159-162).

It is beyond doubt that the concept of sovereignty has changed over time in light of this new global principle of legitimacy, namely respect for human rights. Human rights provide a regulatory source of limitations on the prerogatives of sovereign states and a government's power. However, sovereignty has not been displaced by human rights. As Jean Cohen rightly argued, international human rights treaties are not designed to abolish state sovereignty and replace it with a cosmopolitan legal order but to encourage states to construct and commit to a common international standard and to abide by it in their domestic law and policies (Cohen, 2012: 162). Sovereignty and human rights are two distinct but interrelated legal principles of the same, dualistic, international political system. This dualistic political system is composed of sovereign states (and the international law they make through consent) and new global governance institutions that provide global cosmopolitan legal elements derived from non-derivative human rights standards. States are still autonomous and self-determining. However, when a state commits genocide or enslavement or oppresses its people in radical ways, it is subject to the international community's concern or potential intervention justified by inviolable human rights (Cohen, 2012: 201-207).

It is also obvious that the international human rights regime differs substantially from other international regimes. Although there has yet to be a systematic comparative analysis of different international law regimes in comparative law studies, it can be argued, as Donnelly did, that unlike other regimes, the international human rights regime verges on authoritative international standard setting, creation and elaboration (Donnelly, 1986: 608). There is an advanced and rich philosophical discourse with a long tradition regarding the nature, essence, scope, and justification of human rights. 
Although interpreted in various ways, there is an accepted view that human rights appeal to a universally valid conception of human well-being and interests. Human rights standards are coherent, strong, and widely accepted. Such concepts as the prohibition of genocide, slavery, and torture are considered jus cogens: they represent fundamental, overriding principles of international law from which no derogation is permitted. There is a relatively complex and centralized system of global governance based on the legalization of human rights and globalization of human rights discourses that includes international standard setting, treaty making and monitoring bodies creating erga omnes obligations, international criminal law and the international criminal court, and, as of late, the development of humanitarian law.

Does international environmental law enjoy comparable authority? Despite its proliferation in recent decades ${ }^{18}$ (there has been considerable activity concerning treaty making, agreements, resolutions, decisions of various international courts and tribunals (there is no international environmental court, however) and soft law instruments such as declarations following environmental conferences and the literature, especially following the Earth Summit in Rio de Janeiro in $1992^{19}$ ) the international environmental protection regime is comparably less authoritative than the human rights regime. In fact, as many observers agree, international environmental law provides an ineffective legal response to environmental degradation (Leary, Pisupati, 2010). Not only is there little compliance with policy goals set in treaties and declarations made in the aftermath of the Rio Summit (especially concerning the reduction of $\mathrm{CO}_{2}$ emissions); the role of international environmental law is actually declining. As Schrijver points out, the World Summit on Sustainable Development in Johannesburg in 2002 focused largely on development goals (reduction of poverty, sustainable food production, the management of natural resources as the basis of social and economic development) and made little reference to the role of international environmental law in promoting the sustainability of resources (Schrijver 2008, 71-76, 95-96).

From the critical perspective of the Earth's vital ecosystems reaching dangerous planetary boundaries that I suggested at the beginning of the paper, the most salient failure of the international regime of environmental protection is that there is no legally and politically relevant conception of global environment or ecological system(s) overlying and complementing the deeply

18. Environmental law is still a very young branch of international law. Current issues of international concern covered by environmental law include ozone layer depletion and global warming, desertification, destruction of tropical rain forests, pollution of air and water, international trade in endangered species (i.e. ivory), shipment of hazardous wastes to Third World countries, deforestation of Brazil and the Philippines, protection of wetlands, oil spills, transboundary nuclear air pollution (i.e. Chernobyl), dumping of hazardous wastes, groundwater depletion, international trade in pesticides, and acid rain.

19. The conference produced important multilateral treaties - Climate Change Convention and Biodiversity Convention. Treaties addressing anti-desertification, the conservation and management of fisheries, and climate change followed in the 1990s (Schrijver, 2008: 68-76). 
embedded division of the Earth into sovereign territories. Not only has international environmental law failed to provide a systematic and elaborate descriptive and prescriptive conception of vital planetary ecosystems (here, the ozone layer, climate system, ocean ecosystem, and tropical rainforests ${ }^{20}$ would be the most obvious examples); it has, as already indicated, not adopted any consistent framework or jurisdiction for domains that are outside of state boundaries (the atmosphere, polar regions, high seas). The common heritage of humankind regime, introduced to promote international cooperation and the sharing of economic benefits among all nations, unfortunately remains a regime of resource use and exploitation with relatively vague implications. An alternative approach, for example that of 'ecological stewardship' (Chapin et al., 2009), which might better respond to the idea of responsible and sustainable use and conservation of the environment, has not yet made it into philosophical and legal debates, and it has not been addressed either in international environmental law or in the theory of territorial or resource rights.

Regrettably, the only relatively well-developed standard that serves as the source for constraints on the state based principle of the permanent sovereignty over natural resources remains that of sustainable development. Having expanded impressively in a relatively short period of time, the concept of sustainable development has indeed become firmly established in international and domestic law. Today, sustainable development (the protection and conservation of the environment and resources for the benefit of present and future generations) represents one of the core values of the international community, similar to peace, security, and human rights (Schrijver, 2008: 29). But does it provide an effective and strong catalogue of limits and duties regarding resource sovereignty?

The introduction of the concept of sustainable development in the 1980s represented a considerable change of paradigm in the practice of resource sovereignty, which until then had been limited by a few standards or principles, such as good neighborliness, the duty not to cause trans-boundary damage and of course limits resulting from the contractual rights of foreign investment companies. Sustainable development has acknowledged resource sovereignty and economic development as primary interests of states; however, it defined such development as being restricted by the capability of future generations to also fulfill their needs via development. ${ }^{21}$ Since the publication of the Brundtland Commission's report Our Common Future, sustainable development has become legally grounded in numerous global and regional treaties in countless areas. It has been solidly embedded in conventions and protocols

20. The International Tropical Timber Agreement (ITTA) is the only agreement to directly address rainforest deforestation. However, the ITTA exclusively focuses on the timber trade, so it cannot completely accomplish the goal of rainforest preservation.

21. This is a definition introduced by the Brundtland Commission (United Nations, 1987): sustainable development is the development that meets the needs of the present without compromising the ability of future generations to meet their own needs. 
addressing climate change, the conservation of biological diversity and marine biodiversity, fisheries and freshwater resources, marine and trans-boundary air pollution, desertification, and other areas. Across various areas, the standard posits a desirable future state for human societies in which the use of the environment and resources meet human needs without undermining their sustainability or capacity to serve the needs of future generations.

The concept of sustainable development has broadened over time. Today, unfortunately, it represents a rather vague notion for everything good for the environment. There is a tendency observed by many critics concerning the weakening of the standard of sustainable development vis-à-vis other general international laws (security and humanity) and also persistent reorientation towards social and economic development. As Schrijver argues, sustainable development has developed from the original meaning of sustainable use of natural resources, i.e. the use that preserves these resources for future use, to an anthropocentric notion with a dominant socio-economic substance. Today, it is intended to serve not simply the needs of environmental protection but also entails reorientation of the international community to the world's economic system and persistent efforts to tackle the problem of development in the Third World (Schrijver, 2008: 217; Birnie et al., 2002: 45).

This tendency is reinforced by the introduction of the 'right to development', the youngest of human rights concepts, and its recognition as a universal and inalienable right and an integral part of the catalogue of fundamental human rights. ${ }^{22}$ The content, nature, and status of this right are still contested and there is no political consensus on its practical interpretation. However, the right to development represents the latest expression of the recurrent effort to reform unjust international economic order towards one based on social welfare and social justice. Hence, a vital link between sustainability and civil, political, economic, and social rights has been fostered, but not with environmental law. ${ }^{23}$ The right to development is aimed at the integration of economic and human rights issues in one coherent policy framework. Rather than evolving parallel to human rights as a standard limiting the economic sovereignty of states, sustainable development thus lost its environmental potential by turning (social and economic) development into a human right. Regrettably, rather than being reinforced and strengthened so as to compensate for the lack of an effective global regime of environmental protection, sustainable development

22. The Declaration on the Right to Development was adopted by the UN in 1986. It defines the right to development as "an inalienable human right by virtue of which every human person and all peoples are entitled to participate in, contribute to, and enjoy economic, social, cultural and political development, in which all human rights and fundamental freedoms can be fully realized." Since then, the UN has devoted substantial resources to elevating the significance of this right and to promoting its implementation. At the World Conference on Human Rights in Vienna in 1993, it was recognized as a universal and inalienable right and an integral part of fundamental human rights.

23. The text of the UNDRD makes no mention of the environment whatsoever (Bunn, 2000: 1442). 
weakened under the impact of the growing significance of social and economic human rights.

Contemporary use of sustainable development in various regimes and discourses emphasizes principles that express the clear statist and economic orientation of the concept. ${ }^{24}$ These principles involve: the duty of states to ensure the sustainable use of natural resources, the principle of equity and the eradication of poverty, the principle of common but differentiated responsibilities of countries, the precautionary principle and environmental impact assessment, public participation, good governance, and the principle of integration and interrelation. These principles reflect the fact that states are committed to correcting the failures of the global economic system and to intra-generational justice (the eradication of poverty) rather than to inter-generational justice; and that industrial nations carry a heavier burden of environmental protection. The emphasis on good governance indicates that there is a shift from environmental protection to general principles of government and resource management such as efficiency, non-corruptibility, transparency, financial accountability, responsibility to civil society, and the legitimacy of decision-making.

Permanent sovereignty over natural resources remains the most significant legal and political framework in any effort to tackle environmental problems. Unfortunately, due to failures by the international environmental regime to promote the conception of non-sovereign territoriality and suitable jurisdiction for it, and due to the growing emphasis on economic development and social justice in domestic state policies, the degree of restraint in resource sovereignty has not really increased over time. In the current interpretation, permanent sovereignty over natural resources thus undermines the urgent need for the global community to assume responsibility for the protection of environment.

\section{Bibliographical references}

Anghie, A. (2005). Imperialism, Sovereignty, and the Making of International Law. Cambridge: Cambridge University Press. <http://dx.doi.org/10.1017/CBO9780511614262>

BARrY, B. (1991). Liberty and Justice: Essays in Political Theory. Oxford: Clarendon Press.

Beitz, C. R. (1990). Political Theory and International Relations. Princeton: Princeton University Press.

BeItz, C. R. (2011). The Idea of Human Rights. New York: Oxford University Press.

Birnie, P.; Boyle, A. and Redqwell, C. (2002). International Law and the Environment. Oxford: Oxford University Press.

24. These principles were formulated at the biennial conference of the International Law Association in 2002 as the New Delhi Declaration of Principles of International Law Relating to Sustainable Development. 
Bunn, I. D. (2000). “The Right to Development: Implications for International Economic Law". American University International Law Review, 15 (6), 1425-1467.

Caney, S. (2005). Justice Beyond Borders: A Global Political Theory. New York: Oxford University Press. <http://dx.doi.org/10.1093/019829350X.001.0001>

Chapin III, F. S.; Kofinas, G. P. and Folke, C. (eds.) (2009). Principles of Ecosystem Stewardship. Resilience-Based Natural Resource Management in a Changing World. New York: Springer.

Cohen, J. L. (2012). Globalization and Sovereignty. Rethinking Legality, Legitimacy, and Constitutionalism. New York: Cambridge University Press. <http://dx.doi.org/10.1017/CBO9780511659041>

DonnelLy, J. (1986). "International Human Rights: A Regime Analysis". International Organization, 40 (Summer), 599-642. <http://dx.doi.org/10.1017/S0020818300027296>

Donnelly, J. (2013). Universal Human Rights in Theory and Practice. Ithaca: Cornell University Press.

Folke, C. (2013). "Respecting Planetary Boundaries and Reconnecting to the Biosphere". In: Is Sustainability Still Possible? Washington: The Worldwatch Institute, 19-27.

Fox, G. H. (2008). Humanitarian Occupation. Cambridge: Cambridge University Press.

GüMplovÁ, P. (2011). Sovereignty and Constitutional Democracy. Baden-Baden: Nomos. $<$ http://dx.doi.org/10.5771/9783845231235>

Hendrix, B. A. (2008). Ownership, Authority, and Self-determination. University Park Pennsylvania: University of Pennsylvania Press.

Hobbes, T. ([1651] 1985). Leviathan. London: Penguin Books.

Ivison, D. (2002). Postcolonial Liberalism. Cambridge: Cambridge University Press.

Kelsen, H. ([1934] 1970). The Pure Theory of Law. Berkeley: University of California Press.

Klabbers, J.; Peters, A. and Ulfstein, G. (eds.) (2009). The Constitutionalization of International Law. New York: Oxford University Press. <http://dx.doi.org/10.1093/acprof:oso/9780199543427.001.0001>

Leary, D. and Pisupati, B. (2010). The Future of International Environmental Law. Tokyo: United Nations University Press.

Locke, J. ([1689] 1980). Second Treatise of Government. Indianapolis: Hackett Publishing.

Macdonald, R. S. J. and Johnston, D. M. (eds.) (2005). Towards World Constitutionalism, Issues in the Legal Ordering of the World Community. Leiden: Martinus Nijhoff.

Nine, C. (2012). Global Justice and Territory. Oxford: Oxford University Press. <http://dx.doi.org/10.1093/acprof:oso/9780199580217.001.0001> 
Nussbaum, M. (2000). Women and Human Development. Cambridge: Cambridge University Press. <http://dx.doi.org/10.1017/CBO9780511841286>

Piкiтch, E. K. (2012). "The Risks of Overfishing”. Science, 338 (6106), 474-475. $<$ http://dx.doi.org/10.1126/science.1229965>

Pogge, T. (2002). World Poverty and Human Rights. Cambridge, MA: Polity Press.

Rockström, J. and Klum, M. (2012). The Human Quest: Prospering within Planetary Boundaries. Stockholm: Bokforlaget Max Strom.

Rocкsтröm, J. et al. (2009). "Planetary Boundaries: Exploring the Safe Operating Space for Humanity". Ecology and Society, 14 (2).

Schrijver, N. (1997). Permanent Sovereignty over Natural Resources. New York: Cambridge University Press. $<$ http://dx.doi.org/10.1017/CBO9780511560118>

Schrijver, N. (2008). The Evolution of Sustainable Development in International Law: Inception, Meaning, and Status. Leiden and Boston: Martinus Nijhoff Publishers. <http://dx.doi.org/10.1163/9789047444466>

Schrijver, N. (2010). Development without Destruction. Bloomington: Indiana University Press.

Siknink, K. (2011). The Justice Cascade: How Human Rights Prosecutions Are Changing World Politics. New York: W. W. Norton \& Company.

Sonntag, M. and Lüth, F. (2012). "Who Owns the Arctic? A Stocktaking of Territorial Disputes". Global, 10.

Sornarajah, M. (2010). The International Law on Foreign Investment. New York: Cambridge University Press. <http://dx.doi.org/10.1017/CBO9780511841439>

Steiner, H. (1996). "Territorial Justice”. In: Caney, Simon; George, David and Jones, Peter (eds.). National Rights, International Obligations. Boulder: Westview Press, 139-148.

Teitel, R. (2011). Humanity's Law. New York: Oxford University Press. <http://dx.doi.org/10.1093/acprof:oso/9780195370911.001.0001>

United Nations (1987). "Report of the World Commission on Environment and Development". General Assembly Resolution 42/187.

World BANK (2009). The Sunken Billions. The Economic Justification for Fisheries Reform. Retrieved from: <http://siteresources.worldbank.org/ EXTARD/Resources/336681-1224775570533/SunkenBillionsFinal.pdf> <http://dx.doi.org/10.1596/978-0-8213-7790-1> 
Petra Gümplová was born in the Czech Republic in 1974. She has a PhD from The New School for Social Research, USA. Since April 2010, she has been an assistant professor of political science at Justus-Liebig-University in Giessen, Germany. She specializes in theories of sovereignty, constitutionalism, territorial and resource rights, and international law. Her book Sovereignty and Constitutional Democracy was published by Nomos in 2011.

Petra Gümplová nació en la República Checa en 1974. Es doctora por la New School for Social Research (Estados Unidos). Desde abril de 2010 es profesora asociada de Ciencias Políticas en la Universidad Justus Liebig de Giessen (Alemania). Sus especialidades son las teorías de la soberanía, el constitucionalismo, los derechos territoriales y de recursos y el derecho internacional. Su libro Sovereignty and Constitutional Democracy fue publicado en 2011 por la editorial Nomos. 


\title{
Globalització, art, geografia
}

\author{
Bernat Lladó Mas
}

Grup d'art geogràfic (Sa)badall

bernat.llado@gmail.com

\section{Resum}

Avui en dia, les metàfores geogràfiques i cartogràfiques són molt presents en el món de l'art. Utilitzar eines i recursos propis de la geografia, especialment el llenguatge cartogràfic, és molt comú en certes pràctiques i discursos artístics contemporanis. Amb tot, han estat pocs els esforços a l'hora d'intentar comprendre i interpretar aquesta situació. En aquest sentit, l'expressió crisi de la raó cartogràfica, elaborada pel geògraf Franco Farinelli, ens hi pot ajudar. Descriurem l'arc que va des del naixement de la raó cartogràfica fins a la crisi actual que pateix. Això ajudarà a entendre l'emergència de l'art cartogràfic. En citarem alguns exemples i els interpretarem tenint en compte el que hem exposat.

Paraules clau: art geogràfic; raó cartogràfica; Franco Farinelli; globalització; crisi de representació.

\section{Abstract. Globalization, art, geography}

The geographic and cartographic metaphors are very present in the today art's world. Tools and resources from geography, especially cartographic language, is commonly used in some contemporary art practices and discourses. However, few efforts have been done to find a suitable interpretation of this situation. A relevant work has been carried out in this topic by the geographer Franco Farinelli, who developed the crisis of cartographic reason concept. We describe the path that goes from the birth of cartographic reasoning to his current crisis, and we cite and interpret some illustrating examples. Moreover, this will help understanding the emergence of the cartographic art.

Keywords: geographic art; cartographic reason; Franco Farinelli; globalization; crisis of representation.

\section{Sumari}

1. Experiència artística i cartografies

2. Origen i significat de la raó cartogràfica

3. Mapes per a la utopia
4. Apunts finals

Referències bibliogràfiques 


\section{Experiència artística i cartografies}

Avui en dia, el món de l'art es caracteritza per una gran pluralitat de pràctiques i discursos. Això no obstant, alguns autors han observat un interès creixent per la geografia i la cartografia. Aquests dos camps delimiten una àrea important de l'activitat artística contemporània. El crític francès Nicolas Bourriaud (2008), per exemple, ha utilitzat recentment l'expressió topocrítica per referirse a tota una sèrie d'experiències i projectes d'art relacionats amb la geografia. Amb tot, cal remuntar-se a finals dels anys vuitanta si un vol entendre els motius d'aquest moviment. De fet, Frederic Jameson (1995) ja ens havia advertit sobre la necessitat i la importància d'allò que anomenava «mapes cognitius globals». Aquests, entre altres coses, havien de permetre articular una nova consciència global, una consciència fortament debilitada per l'erosió del concepte de classe i la fragmentació de l'espai social, arran de la introducció del postfordisme durant els anys setanta. No és cap casualitat que la reivindicació de Jameson es produís justament l'any 1989, data simbòlica en què es produí la caiguda del mur del Berlín i el naixement de la globalització. Des d'aleshores, certament, les exposicions artístiques que giren al voltant de la representació cartogràfica s'han succeït de forma ininterrompuda, des de l'exposició Putting the Land on the Map: Art and Cartography in New Zeland since 1840 (Govett-Brewster Art Gallery, Nova Zelanda, 1989), fins a Cartografies contemporànies: Dibuixant el pensament (CaixaFòrum, Barcelona, 2013), passant per Mapping (Moma, Nova York, 1994) (Watson, 2009).

Per tal de proporcionar un marc general que ens permeti explicar o, si més no, donar sentit a l'emergència de les pràctiques artístiques vinculades a la geografia i a la cartografia, l'autor que, des del meu punt de vista, ens hi pot ajudar més és el geògraf Franco Farinelli. Fet i fet, a finals dels anys noranta, aquest mateix autor ja havia afirmat que la geografia futura hauria de ser un "treball d'artistes», una geografia capaç «d'inventar esquemes expressius nous, figuracions lògiques noves, imatges noves i conceptes emancipats nous finalment d'allò que [Karl] Ritter condemnava ja com la "dictadura cartogràfica": models nous per a la representació del món» (Farinelli, 1999: 16). Que la geografia hagi de ser un treball d'artistes no vol dir que siguin aquests els únics que puguin donar forma i figura al món d'avui; també vol dir que els mateixos geògrafs i geògrafes han de ser més artistes. D'altra banda, la mateixa història de la cartografia ens dóna algunes pistes sobre fins a quin punt la partició actual dels sabers - la geografia, d'una banda, les pràctiques artístiques, de l'altra- és una construcció recent. En la seva Història, Heròdot, comenta amb ironia el primer mapa que la tradició occidental recorda: el mapa d'Anaximandre. Per a ell, la forma circular que mostrava indicava l'origen artesà de la seva construcció —el fet d'estar fabricat sobre un torn de terrissaireA les cartes de bord de Cristòfor Colom que s'han conservat gràcies a Bartolomé de las Casas, l'almirall anuncia als Reis Catòlics que està a punt de finalitzar una pintura, és a dir, un mapa de les Índies Occidentals. Aquests són només alguns exemples agafats a l'atzar, a fi de mostrar fins a quin punt 
la línia que ha separat l'art de la cartografia és molt més fina del que avui en dia ens pensem.

Si la geografia necessita models nous per representar el món és perquè els models existents ja no ens serveixen. Segons Farinelli (2009), això és el resultat de la crisi de la raó cartogràfica. Que aquest mateix autor situï històricament l'inici d'aquesta crisi l'any 1969 (el mateix any en què algú contemplà la Terra des de l'espai exterior per primera vegada i en què es connectaren dos ordenadors entre ells), d'una banda, i l'any 1989, de l'altra, és prou simptomàtic. Al meu entendre, la centralitat del mapa en bona part de la cultura artística contemporània, es pot interpretar com un reflex d'aquesta crisi. Per això, qui intueix d'una forma més clara que la futura geografia serà un treball d'artistes és el mateix Farinelli. Aquest autor, que jo sàpiga, és un dels primers que ens ha recordat una cosa que, d'altra banda, la geografia alemanya del segle XIx ja havia avançat: que la raó cartogràfica no ens deixa pensar lliurement; d'aquí que Karl Ritter parlés de la «dictadura cartogràfica». Ara bé, què és la raó cartogràfica $i$, sobretot, per què avui en dia estaria en crisi?

\section{Origen i significat de la raó cartogràfica}

La cartografia no és només un instrument que ens permet representar, conèixer i intervenir sobre el territori. És una modelització del món. Ens diu no només què hem de conèixer i com ho hem de conèixer, sinó també la manera d'organitzar-nos territorialment i política. D’aquí que, segons Farinelli, el mapa no sigui una representació del món, com informen els diccionaris, sinó una construcció d'aquest, o, per utilitzar les seves mateixes paraules, el mapa no sigui la còpia del territori, sinó al revés. De bon començament, la cartografia ha estat, al mateix temps, un model epistemològic i un model polític. Tornem a l'època d'Anaximandre: el segle $\mathrm{v}$ abans de Crist. Seguint l'historiador Jean-Pierre Vernant, Farinelli ha relacionat el mapa circular d'Anaximandre amb el model polític grec de la isonomia, el precedent directe de la democràcia de Pèricles (Farinelli, 1994; Vernant, 1992), però també hauria estat un nou paradigma cognitiu. De fet, afirma Farinelli, si, pels contemporanis d'Anaximandre, la seva representació del món resultava incòmoda, no només era perquè adoptava un punt de vista fins aleshores reservat als déus, des d'una alçada inabastable sobre la vertical d'Atenes, sinó també perquè presentava un esquema estàtic i inert d'una naturalesa que, per a ells, era un moviment continu. Els grecs, com diria Heràclit, mai es banyaven dos cops al mateix riu.

Aquesta doble vessant dels mapes, model polític i epistemològic al mateix temps, adopta, durant el Renaixement, una dimensió inesperada. Durant aquesta època, sorgeix el que podríem anomenar, pròpiament, la cartografia moderna. El sistema de coordenades i un context de ciència positiva contribueixen a promoure la idea segons la qual la cartografia és un instrument que representa el món de forma objectiva. Les imprecisions i els esquemes simbòlics serien cosa del passat. Ara bé, realment, els esdeveniments havien anat així? No. També per a la cartografia moderna podem afirmar que és, alhora, un model 
polític i un model epistemològic. Segons Farinelli, en efecte, no només seria el model territorial de l'estat nació, sinó que l'epistemologia moderna, és a dir, la ciència que estudia com es pot assolir un coneixement vertader (i no la mera opinió), tindria com a paradigma la descripció de la projecció cartogràfica.

A finals del segle XIV, arribà a Florència, procedent de Constantinoble —l'antiga Bizanci i aleshores ocupada pels otomans (1453) —, un exemplar de la Geografia de Ptolemeu. El geògraf $\mathrm{i}$ astrònom grec havia escrit l'obra durant el segle II $\mathrm{dC}$ a Alexandria, però aquesta havia restat oblidada durant tota l'edat mitjana. Bàsicament, era un tractat on s'ensenyaven diferents tècniques per descriure, és a dir, projectar, segons el llenguatge instaurat en aquell moment, l'esfera terrestre sobre una superfície plana. L'obra recollia, al mateix temps, les ensenyances matemàtiques i geomètriques d'Euclides. Per primera vegada en la història de la cartografia occidental, la imatge cartogràfica incorporava un sistema de meridians i paral.lels i, per tant, la idea d'espai, d'extensió, és a dir, una construcció abstracta que permetia traslladar cada punt de la superfície terrestre sobre una quadrícula artificial i plana.

Alguns historiadors de l'art han suggerit que la perspectiva lineal del Renaixement, responsable de la nova cultura visual de l'època, hauria estat una conseqüència de l'arribada i la traducció al llatí de la Geografia. Els experiments d'un Brunelleschi o les teories sobre l'art i la construcció d'un Alberti no serien res més que l'adaptació $\mathrm{i}$ la influència de les tècniques cartogràfiques de Ptolemeu. En qualsevol cas, una cosa és certa: per primera vegada en la història d'Occident, l'espai esdevé un apriorisme social i compositiu. Des del punt de vista artístic, l'espai, és a dir, la quadrícula o malla geomètrica, precedeix el dibuix dels objectes i les figures, que es van ordenant en funció de la "profunditat» fins que es perden en el punt de fuga. Només cal observar les pintures d'èpoques anteriors per adonar-se que, en aquest cas, són les figures, els objectes i les relacions entre si allò que determina el «buit». De fet, es podria dir el mateix dels portolans, la tradició cartogràfica anterior. Si un observa, per exemple, el famós Atles Català d'Abraham Cresques, realitzat el 1375, veurà que són els elements que conformen el mapa allò que en determina les relacions: no podem calcular la distància entre dos punts perquè no se segueix cap sistema de coordenades $i$, per tant, la idea d'espai o d'escala no hi és present. Així mateix, el punt de vista del cartògraf, a diferència del punt de vista de la perspectiva renaixentista, no és unitari ni estàtic: d'aquí que, al mapa de Cresques, les figures i els objectes tan aviat estiguin del dret com del revés. Amb l'art i la cartografia del Renaixement, es perden aquestes qualitats narratives.

L'historiador Harald Kleinschmidt (2009) ha observat recentment que, sobretot durant l'alta edat mitjana, eren els grups qui creaven el territori; en canvi, a partir del Renaixement, comença a succeir més aviat el contrari: és l'espai qui constitueix els grups. Curiosament, aquest trànsit és coherent amb l'evolució de la pintura descrita abans. Un fet directament relacionat amb l'aparició dels primers estats nació a Itàlia.

El fet que l'origen de la cartografia moderna i l'aparició dels primers estats nació durant el Renaixement sigui contemporània no és merament una casua- 
litat històrica. Si seguim de nou Franco Farinelli, podem dir que els dos esdeveniments mantenen una lògica interna. La forma territorial dels estats nació acaba adoptant les propietats geomètriques de l'espai euclidià. De la mateixa manera que el mapa d'Anaximandre representava no només el món conegut pels grecs, sinó també la forma geogràfica de la isonomia, els mapes que es dibuixen a partir del Renaixement representen igualment un model polític determinat: els estats nació. D'aquí que Farinelli pugui afirmar allò que ja s'ha apuntat més amunt: contràriament al que ens diuen els diccionaris, el mapa no és la còpia o representació del territori, sinó al revés. Ara bé, quines són aquestes propietats de l'espai cartogràfic que la nova forma territorial dels estats nació assumeix?

De la mateixa manera que l'espai euclidià és homogeni, també l'estat nació ho ha de ser. No és eventual, en aquest sentit, que l'Espanya dels Reis Catòlics expulsés, l'any 1492, jueus i musulmans del seu territori; o que la primera gramàtica espanyola, obra de l'humanista Antonio de Nebrija i escrita amb la intenció de crear una «llengua unificada» que contrarestés la pluralitat de variants existents, també fos escrita aquest mateix any. Fet i fet, l'antecedent directe de la gramàtica de Nebrija era la Linguae latinae elegantiorum de Lorenzo Valla, que, al prefaci, ja observava que la reconstrucció de l'Imperi romà, aleshores del tot desdibuixat, no es podia només assolir per mitjà de les armes, sinó que també calia "posar de relleu el poder subjacent de la llengua com a força unificadora sobre les conquestes geogràfiques» (Mignolo, 2003: 333). A diferència de les territorialitats anteriors, com ara, per exemple, els imperis, que incloïen certa pluralitat cultural al seu interior, els estats nació es caracteritzen per la construcció d'una homogeneïtat cultural i identitària (Colás, 2009). És en aquest punt on val la pena recuperar l'etimologia de la paraula nació, que ve de naixement. La identitat de les persones prové, d'ara endavant, del lloc on es neix. L'espai constitueix els grups i no al revés, com hem vist que succeïa durant tota l'edat mitjana. Un fet, per cert, del tot coherent amb la perspectiva. L'espai és, en aquest sentit, un apriorisme social. Però aquesta no és l'única característica de l'espai euclidià.

La quadrícula geomètrica és contínua, de la mateixa manera que la nova territorialitat dels estats. Fixem-nos, per exemple, en la Corona d'Aragó, que incloïa territoris dispersos, o també l'Imperi dels Habsburg. Certament, tant l'una com l'altra, abasten períodes que van més enllà del Renaixement, però mostren que la forma contínua i no fragmentària dels territoris estatals és una construcció relativament recent. Aquí l'important és adonar-se que la formació dels estats nació no és un procés lineal ni homogeni per a tots els països, però que al final s'ha acabat imposant com l'única forma territorial possible (a Occident, entre la Pau de Westfalia i els tractats de pau posteriors a la Primera Guerra Mundial; a la resta del món, després de la descolonització). De la mateixa manera que s'ha imposat la tercera i última propietat de l'espai euclidià: la isotropia, és a dir, el fet que tots els punts conflueixin en una mateixa direcció, la capital de l'estat. Farinelli (2001) recorda que Ptolemeu escriví la seva Geografia en el moment àlgid de l'Imperi romà, un imperi que no hauria 
tolerat cap representació que no fos monocèntrica. La frase «Tots els camins porten a Roma» no s'inventà per tranquil-litzar només els viatgers erràtics. De fet, segons Harald Kleinschmidt, durant l'edat mitjana, la seu del monarca sovint era itinerant. No va ser fins un temps després, coincidint amb l'origen dels estats, que la capital es constituí com un lloc permanent i central. Amb la modernitat, deixa de ser la persona qui encarna el poder; d'ara endavant, és més aviat l'espai qui n'autoritza l'exercici. La Casa Blanca, el Palau de la Moncloa o Downing Street en serien només alguns exemples.

Al llarg de la modernitat (que, en el context d'aquest article, s'inicia durant el Renaixement i, més concretament, amb la traducció al llatí de la Geografia de Ptolemeu), la forma geomètrica del mapa esdevé, per tant, el model d'una nova territorialitat. No només en el sentit que la cartografia moderna proporcionarà l'imaginari territorial on es construeixin les identitats nacionals, sinó també en un sentit físic, material. La morfologia territorial dels estats és, en efecte, un producte de la raó cartogràfica. Si més no, com hem vist, és coherent amb les propietats geomètriques de l'espai euclidià.

Però la cartografia moderna no només anuncia un model politicoterritorial determinat, sinó que també proposa un paradigma epistemològic que acabarà sent hegemònic fins a la postmodernitat. A grans trets, aquest es caracteritza per una separació entre el subjecte que coneix i allò que vol conèixer; entre el primer i l'objecte s'interposa una distància; no existeix cap implicació mútua entre l'un i l'altre: els estats d'ànim del món deixen de correspondre's amb els estats d'ànim dels homes i les dones (Spitzer, 2008). El nou subjecte és transcendental: va més enllà de la seva condició històrica, social o corporal. De fet, coincideix amb un punt, el punt de projecció (subjectum era, curiosament, el mot que els humanistes del Renaixement utilitzaven per referir-se al punt d'observació de la perspectiva) (Damisch, 1997). Un punt que és pur intel.lecte, sense cos. No és per atzar que un autor com Martin Jay (2003) utilitzi l'expressió perspectivisme cartesià per referir-se a aquest paradigma: el cogito de Descartes no és res més que el subjecte de la perspectiva. Un subjecte, per cert, que identifica el coneixement amb la visió i, per tant, amb la seva representació: només es pot conèixer allò que es pot representar. Aquest paradigma, a més, coincideix plenament amb l'obsessió per calcular-ho tot, per mesurar-ho tot, especialment el temps i l'espai (Crosby, 1998). La idea d'una raó universal i homogènia, que comença a obrir-se pas durant aquesta època, no seria res més que el resultat d'aquesta doble disciplina: un subjecte transcendental identificat amb un punt $\mathrm{i}$, per tant, monològic (és a dir, un subjecte que no arriba al coneixement mitjançant el diàleg, sinó només per mitjà del monòleg, el «jo penso» de Descartes); i una naturalesa transformada en una extensió, en un espai mesurable segons un patró mètric normalitzat.

La cartografia moderna també transformà, per tant, la naturalesa del propi coneixement. D’aquí que el mateix Farinelli ens parli de la geografia com del saber arquetípic d'Occident. Etimològicament, arquetípic vol dir 'allò que és original, que precedeix en el temps', un sentit que el trobaríem present a la paraula arcaic, però també pot voler dir 'poder', com ara, per exemple, al mot 
anarquia, que significa, justament, 'absència de poder' (Scavino, 2009). El mapa és, alhora, l'origen d'una manera determinada d'entendre la ciència i el coneixement i de la territorialitat moderna. Que també sigui un dispositiu de poder no vol dir només que, efectivament, hagi estat tradicionalment un instrument per governar, sinó també que té la capacitat de determinar el que existeix i el que no.

En qualsevol cas, avui en dia, aquesta raó cartogràfica estaria en crisi. Si, d'una banda, la globalització ha pogut erosionar les bases territorials dels estats nació, de l'altra, la postmodernitat ha posat en dubte la raó universal i el subjecte de la metafísica. Situar el conjunt de pràctiques i de discursos artístics i culturals que giren al voltant de la cartografia o la geografia — allò que Bourriaud anomenava topocrítica - en un context de crisi general de la raó cartogràfica, podria ser la millor manera de proporcionar un sentit global a tot plegat. Certament, cada artista té una trajectòria particular, i cada obra, el seu context determinat. Però val la pena adoptar una perspectiva àmplia si es vol pensar històricament. A continuació, intentaré proporcionar un marc general que, en vista del que s'ha escrit fins ara, ens permeti iniciar una possible via d'interpretació d'algunes de les pràctiques o experiències artístiques contemporànies que treballen amb la cartografia. La intenció és situar aquestes pràctiques en el si de la crisi de la raó cartogràfica. Dit d'una altra manera: cercar-ne la genealogia històrica. No pretenc, per tant, ser exhaustiu amb tot el conjunt d'artistes i moviments que, segons el meu parer, treballen en aquest camp, sinó només insinuar «l'esperit de l'època» que els acompanya.

\section{Mapes per a la utopia}

L'aspecte que defineix la globalització d'una manera més precisa és el de la possibilitat de connectar diferents punts del planeta simultàniament $\mathrm{i}$ instantània. La globalització no és només la internacionalització de les transaccions i les relacions comercials entre països, un fenomen que s'inicià molt abans (abans, fins i tot, de l'emergència del circuit comercial de l'Atlàntic). Tampoc és el resultat de la liberalització dels mercats, que arrenca, com a mínim, a finals del segle xIx; i, encara que pugui semblar paradoxal, la globalització tampoc no es pot descriure tan sols com un procés d'homogeneïtzació cultural. Tots aquests aspectes, encara que siguin característics i descriguin aspectes importants de la globalització, no ens ajuden a entendre el significat precís del terme. Per a alguns autors, la simultaneïtat i la rapidesa instantània de les comunicacions i les informacions crea un nou espai social que anomenen supraterritorial; un espai que no s'ajusta ja a la "quadrícula territorial» de matriu ptolemaica (Scholte, 2004). Aquest és l'espai inèdit de la globalització, un espai on la distància topogràfica ja no és la variable determinant (que cedeix el lloc a l'accés a les xarxes). Quan l'artista Mark Lombardi (2003) realitza un «mapa» dels fluxos financers globals, o els Bureau d'Études (2003) estableixen les relacions mundials dels mitjans de comunicació de massa, no fan res més que inventar «esquemes expressius nous» desvinculats de la lògica cartogràfica. 
Però no és únicament la distància mètrica, sorgida amb la projecció moderna, allò que la globalització fa entrar en crisi. La mateixa estructura territorial dels estats també viu moments crítics. La continuïtat es fragmenta en virtut de les xarxes, $\mathrm{i}$ les fronteres territorials que delimitaven una sobirania exclusiva fa temps que han perdut eficàcia (encara que, en molts punts del planeta, es continuïn aixecant murs i contenint poblacions). El mapa de Susan Stockwell, titulat America, an imperial State (2010), descriu de forma subtil aquesta pèrdua de sobirania. La governança, la multiescalaritat, la construcció de grans espais econòmics, com ara, per exemple, la UE o alguns organismes globals com ara l'FMI o l'OMC, estan creant territorialitats noves que van més enllà de la lògica cartogràfica centrada en l'estat, de la mateixa manera que ho fan alguns dels circuits globals que escapen a les estadístiques de base territorial: màfies, fluxos financers, comerç il.legal, crim organitzat, guerra cibernètica, etc. I l'homogeneïtat, aquesta qualitat que els estats haurien "copiat" de l'espai euclidià del mapa? Per molt que els estats continuïn el seu procés de consolidació (recentralització, homogeneïtzació i construcció nacional), el món de la globalització podria indicar direccions noves.

La crisi de la raó cartogràfica té una altra connotació. Cal situar-la en el context postmodernista d'una doble crisi: la del subjecte transcendental, d'una banda, i la de la raó il.lustrada, de l'altra. El primer coincidia, com hem vist, amb el punt de la projecció. Subjecte puntual, monològic, analític: el subjecte de la perspectiva, diu Merleau-Ponty (2006) amb raó, és un "pur subjecte descarnat». No és cap casualitat que, des de vessants molt diverses, el postmodernisme hagi reivindicat el cos com a experiència i font de coneixement. Reivindicació de la vivència, tant corporal com emocional, del territori; crítica a la construcció artificial i convencional de l'espai. Céline Boyer ens ho recorda amb el projecte Empreintes (2013): el tacte de les mans reclama el protagonisme perdut enfront del domini visual de la raó cartogràfica. D'altra banda, com hem d'interpretar l'artista Quin Ga a Long March Projecte (2002), un tatuatge corporal que ressegueix i cartografia la Gran Marxa de Mao durant els anys 1934 i 1935? Si el grup Iconoclasistas prepara tallers de "mapeo colectivo", no és precisament per tal de sortir d'aquest subjecte puntual i monologic i proposar cartografies dialògiques, recollint les idees, entre d'altres, d'un Richard Rorty o d'un Jürgen Habermas al voltant de la conversa i de l'acció comunicativa com a mitjà per aproximar-se a la veritat $\mathrm{o}$ a la realitat? $\mathrm{O}$ quan Sitesize (2008) demana als ciutadans de Manresa que dibuixin la seva ciutat per tal de crear un arxiu d'interpretació territorial, no s'interessen pel subjecte situat, és a dir, de carn i ossos, amb tot el que això comporta (diferència de gènere, de classe, d'ètnia, d'edat, etc.)?

Si la raó cartogràfica adopta un punt de vista unitari, la seva crisi reclama una pluralitat de perspectives. Perquè les coses es mouen, es transformen, amb la qual cosa deixen espais fragmentats i heterogenis. D'aquí que, sovint, les noves cartografies adoptin la tècnica del collage. Quan els alumnes del taller de dibuix de l'Escola Illa de Sabadell, amb l'Oriol Vilapuig, realitzen un mural per explicar les transformacions de Sant Pau de Riu-Sec (2012), evoquen la 
metàfora del territori com a palimpsest molt millor que qualsevol cartografia convencional (imatges 1 i 2) (Corboz, 2004). Molt millor, sens dubte, que el treball innovador i pioner de les planimetries d'un Joan Vila Casas, encara massa proper a la lògica topogràfica.
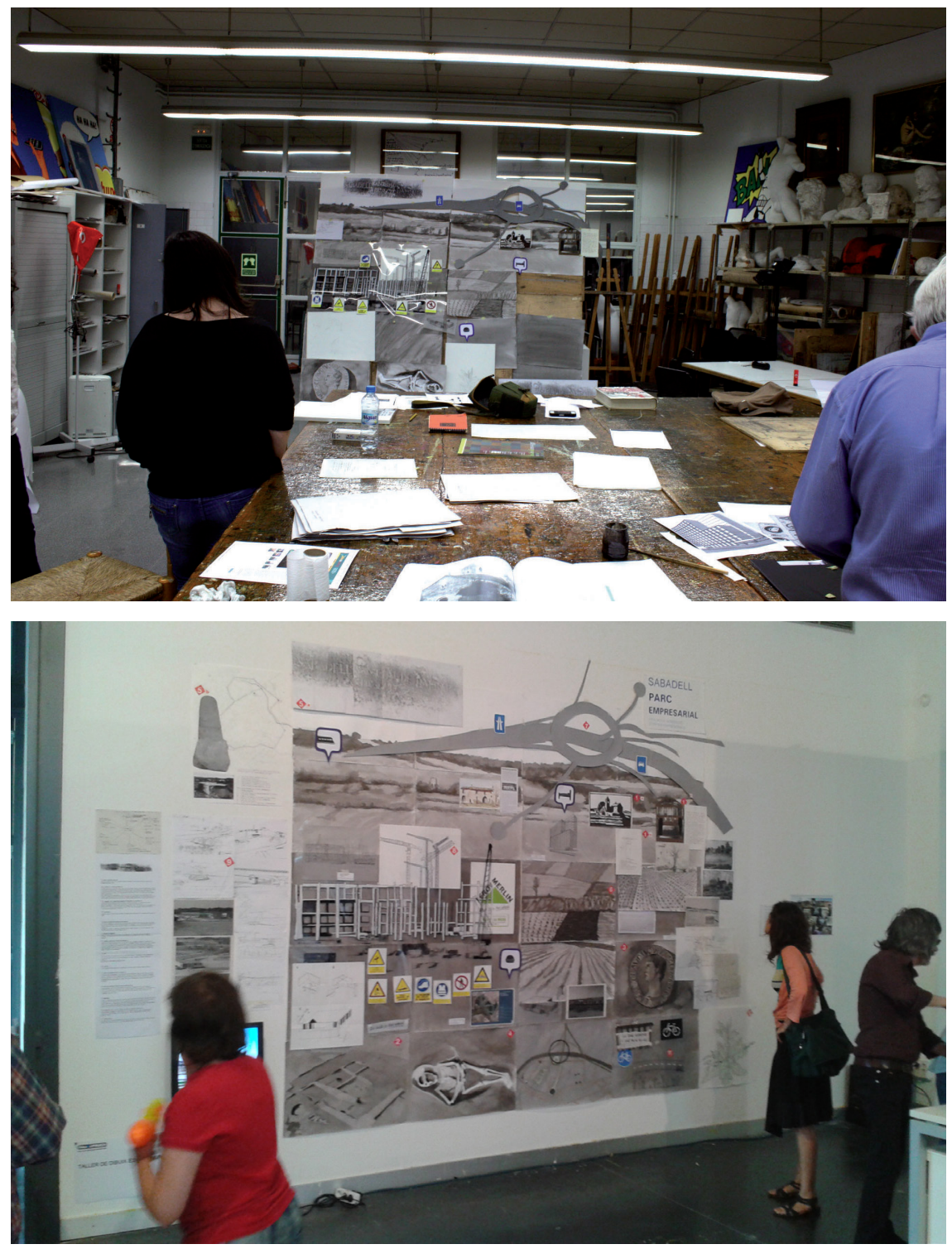

Imatges 1 i 2. Mural realitzat pels alumnes de l'Escola Illa de Sabadell. Fotografies cedides per Oriol Vilapuig. 


\section{Apunts finals}

Podríem seguir, perquè els exemples no s'esgoten. Només he volgut mostrar que, efectivament, en el món de l'art, hi ha un interès creixent per la geografia i la cartografia. Un interès que es pot localitzar en un context ampli, el de la crisi de la raó cartogràfica. Si hem situat l'origen d'aquesta raó durant el Renaixement, inici de la modernitat occidental, la crisi corresponent es pot establir a finals dels anys vuitanta, en ple debat sobre la postmodernitat i la globalització.

L'any 2004, Ruth Watson construeix un globus terraqüi reflectant. No hi ha res dibuixat, només una inscripció, una citació del llibre d'Oscar Wild The Soul of Man under Socialism, escrita l'any 1891. Diu: «Un mapa del món que no inclogui la utopia, no val la pena ni mirar-se'l». De fet, contradient el missatge de Wild, podríem dir que tots els mapes tenen un component utòpic. Perquè els mapes no representen només com són les coses, sinó també com haurien de ser. No són un dibuix del món, sinó un projecte, un pla (tal com ens recorda no només el terme anglès plan, sinó també el mateix origen de la paraula projecció: terme procedent de l'alquímia per referir-se al darrer i decisiu pas per tal de transformar els metalls vulgars en or). Projectem el món tal com ens agradaria que fos. Si una persona s'acosta a poc a poc al globus de Ruth Watson, fins a tocar-lo pràcticament amb la punta del nas, hi veurà reflectit aquell personatge de Borges (1960) que un dia es proposà la tasca de dibuixar el món:

A lo largo de los años puebla un espacio con imágenes de provincias, de reinos, de montañas, de bahías, de naves, de islas, de peces, de habitaciones, de instrumentos, de astros, de caballos y de personas. Poco antes de morir, descubre que ese paciente laberinto de líneas traza la imagen de su cara.

\section{Referències bibliogràfiques}

Borges, Jorge Luis (1960). «Epílogo». El hacedor [en línia]. <http://www. literatura.us/borges/hacedor.html>

Bourriaud, Nicolas (2008). «Topocrítica: El arte contemporáneo y la investigación geográfica». A: VV. AA. Heterocronías: Tiempo, arte y arqueologías del presente. Murcia: Cendeac, 69-82.

Colás, Alejandro (2009). Imperio. Madrid: Alianza Editorial.

Corboz, André (2004). «El territorio como palimsesto». Lo urbano en 20 autores contemporáneos. Barcelona: Edicions UPC.

Crosby, Alfred W. (1998). La medida de la realidad: La cuantificación y la sociedad occidental, 1250-1600. Barcelona: Crítica.

Damisch, Hubert (1997). El origen de la perspectiva. Madrid: Alianza Editorial.

Farinelli, Franco (1994). «Squaring the Circle, or the Nature of Political Identity». A: Farinelli, Franco; Olsson, Gunnar i Reichert, Dagmar (coord.). Limits of Representation. Munic: Accedo, 11-28. 
- (1999). «La globalizzazione». I viaggi di Erodoto, 40, 9-16.

- (2001). «Mapping the Global, or the Metaquantum Economics of Myth». A: Minca, Claudio (ed.) Postmodern Geography: Theory and Praxis. Londres: Routledge, 238-254.

- (2009). La crisi della ragione cartografica. Torí: Einaudi.

Jameson, Frederic (1995). El posmodernismo o la lógica cultural del capitalismo avanzado. Barcelona: Paidós.

JAY, Martin (2003). Campos de fuerza: Entre la historia intelectual y la crítica cultural. Barcelona: Paidós.

Kleinschmidt, Harald (2009). Comprender la Edad Media: La transformación de ideas y actitudes en el mundo medieval. Madrid: Akal.

Merleau-Ponty, Maurice (2006). El mundo de la percepción: Siete conferencias. Argentina: Fondo de Cultura Económica.

Mignolo, Walter (2003). Historias locales/diseños globales: Colonialidad, conocimientos subalternos y pensamiento fronterizo. Barcelona: Akal.

Scavino, Dardo (2009). El señor, el amante y el poeta: Notas sobre la perennidad de la metafísica. Buenos Aires: Eterna Cadencia.

Scholte, Jan Aart (2004). «La globalización y el auge de la supraterritorialidad». A: Morata, Francesc; Lachapelle, Guy i Paquin, Stéphane (ed.). Globalización, gobernanza e identidades. Barcelona: Fundació Carles Pi i Sunyer d'Estudis Autonòmics i Locals, 11-50.

Sitesize (2008). SIT Manresa: Servei d'Interpretació Territorial. Barcelona: Sitesize.

Spitzer, Leo (2008). Ideas clásica y cristiana de la armonía del mundo. Madrid: Abada.

Vernant, Jean-Pierre (1992). Los orígenes del pensamiento griego. Barcelona: Paidós.

Watson, Ruth (2009). «Mapping and Contemporary Art». The Cartographic Journal, 46 (4), 293-307.

Bernat Lladó Mas és doctor en Geografia Humana per la Universitat Autònoma de Barcelona. És autor del llibre Franco Farinelli: Del mapa al laberinto (Icaria, 2013). Ha publicat articles en diverses revistes al voltant de la història de la geografia i la cartografia. Forma part del grup d'art geogràfic (Sa)badall (http://sabadall.wordpress.com/), amb qui ha realitzat el projecte Urbanoporosi: Sabadell i els silencis urbans (2012). Escriu al blog Sirventès: Revista Digital de Cultura $i$ Pensament.

Bernat Lladó Mas obtained the PhD in Human Geography by the Autonomous University of Barcelona in 2010. He is the author of the book Franco Farinelli: Del mapa al laberinto (Icaria, 2013). He has published many articles in various journals of the area History of Geography and Cartography. He is a founding member of the geographical art group (Sa)badall (http://sabadall. wordpress.com/) and one of the authors of the book and exhibition called Urbanoporosi: Sabadell and urban silence, a multidisciplinary work presented in 2012. He is also an active blogger in Sirventès: Revista Digital de Cultura i Pensament. 



\section{RESSENYES}

Veríssimo Serrão, Adriana (coord.) (2011)

Filosofia da Paisagem: Uma Antologia

Lisboa: Centro de Filosofia da Universidade de Lisboa, 502 p.

Traducción de Adriana Veríssimo Serrão et al.

ISBN 978-972-8531-96-6

Adriana Veríssimo Serrão, profesora asociada con agregación del Departamento de Filosofía de la Facultad de Letras de la Universidad de Lisboa, es la principal investigadora y coordinadora del proyecto de investigación Filosofía y arquitectura del paisaje, subvencionado por la Fundación para la Ciencia y la Tecnología y desarrollado en el Centro de Filosofía de la Facultad de Letras de la Universidad de Lisboa, en colaboración con el Centro de Estudios de Arquitectura Paisajista Caldeira Cabral.

La obra antológica Filosofía del paisaje es el resultado del trabajo colectivo e interdisciplinario de los investigadores de dicho grupo (alumnos de máster y doctorado), que, bajo orientación y planificación organizacional de Adriana Veríssimo Serrão, han colegido y traducido un conjunto de textos de autores acreditados en el marco de la reflexión sobre el concepto de paisaje en su tríplice acepción -ontológica (esencia y cualidad del paisaje), estética (los modos de apreciación y valoración del paisaje) y ética (las posibilidades y los límites de la actuación en el contexto paisajístico).
El título del proyecto plantea, de suyo, el tema en cuestión, que no resulta entendido de modo descriptivo, sino bajo el ángulo de su problematización propia. Ello significa que el paisaje, aquí y ahora, no es simplemente un lugar bello que la vista alcanza, sino, sobre todo, el lugar en que el hombre se instala familiarmente con su entorno y consigo mismo, distintivo del modo más íntimo de inserción de lo humano en un orden del mundo en el que participa.

Así pues, tomado en cuanto espacio de expresión y manifestación del ser del hombre, o instaurado, de modo más radical, como reavivamiento del Ser (en la continuidad física, emocional, psicológica, entre el hombre y lo que le circunda), el paisaje exhibe su significado ontológico, que, entendido de esta manera, se planteará frente al actuar como cuidado y amor. Estas dimensiones, ontológica y ética, se encuentran presentes subliminalmente en la apreciación de lo bello natural, cuyo rango llegará a exceder, en consecuencia, el plano de la estética artística y se presentará en cuanto compo- 
nente integrante de una estética contemporánea, con la problematicidad a él inherente.

La organización del volumen refleja la intención de dar (en el sentido literal de ofrenda) el concepto en su forma problemática e interpretativa, mediante la exposición de sus diferentes rasgos, mostrando, a la vez, su función de mediación respecto a contextos aparentemente opuestos («I. El paisaje entre naturaleza, campo y ciudad»; «II. El paisaje entre naturaleza y cultura»; "III. Apreciar el paisaje: el rango de lo bello natural», y «IV. Entre estética y ética: el futuro del paisaje»), con una orientación deliberada por la vía del debate pendiente, que, de ese modo, inaugura diversos caminos de posibilidades reflexivas. Por eso mismo, la convocación de autores sigue la coherencia de interpelación, cuestionadora y reflexiva de la obra, reuniendo distintos enfoques y posiciones, que a veces llegan incluso a ser opuestas, pero fundamentales, siempre, en el estudio de los diversos temas.

El texto introductorio, de Adriana Veríssimo Serrão, «El paisaje como problema de la Filosofía», precede la estructuración del libro en cuatro secciones, anunciando, con claridad, la vía reflexiva inherente al pensamiento del paisaje, aclarando la complejidad semántica del concepto en distintos momentos históricos y culturales, en un registro que procura su fin desde el comienzo - la reconceptualización filosófica del paisaje, situándolo más allá de una determinada región espacial y presentándolo como categoría del pensamiento resultante de la categoría englobante de naturaleza (Georg Simmel).

La sección I ( $\mathrm{El}$ paisaje entre naturaleza, campo y ciudad») está compuesta por cuatro ensayos y comienza con el texto que funda la "apropiación» filosófica del concepto de paisaje, configurándolo como categoría de pensamiento: «Filosofía del paisaje», de Georg Simmel. Con este ensayo preliminar, queda anun- ciada la línea de orientación de la primera sección, en la que se problematiza la génesis del significado de paisaje, en cuanto dato de conciencia. Así pues, el paisaje no es solamente representación del mundo e interpretación pictórica de la naturaleza (Frédéric Paulhan), tampoco una mera zona delimitada de la realidad, sino que, asimismo, constituye experiencia del individuo moderno (Georg Simmel) que evoca a un mundo pasado, a una unidad perdida, en definitiva (Joachim Ritter). Según José María Sánchez de Muniaín, el campo ocupa el lugar de lo que se ha perdido y coincide con la noción misma de paisaje (como entidad que contrasta con la ciudad), donde todavía permanece intacta la naturalidad de los elementos que el citadino busca como terapia, higiene de vida y reviviscencia de la religiosidad.

La sección II («El paisaje entre naturaleza y cultura») abarca seis ensayos y comienza con «Un intento de clarificación conceptual», propuesto por Rosario Assunto, respecto a los términos paisaje, ambiente y territorio, un texto que apunta esencialmente hacia la densidad conceptual aquí reflejada: el paisaje como categoría mixta y compleja en su bipolaridad entre naturaleza y cultura. Si Eugenio Turri, Augustin Berque y Alain Roger destacan que el paisaje resulta ser una «esfera de significaciones»y, por eso mismo, creación cultural, en la misma línea de Nicolas Grimaldi, que considera que la naturaleza tan solo resulta bella para nosotros gracias a la mediación del arte, Michel Corajoud acentúa más bien la naturalidad del paisaje, definido por él como el lugar donde el cielo y la tierra se tocan, atestiguando su destrucción por la invasiva y totalitaria presencia simbólica que desrealiza el mundo y lo sustituye gradualmente, desfigurando lo que se hallaba ahí: Lo que contemplo hoy, ya no es la exterioridad sedimentar, sino que la imagen sin profundidad, que ya no es mundo, sino su representación. 
La sección III («Apreciar el paisaje: el estatuto de lo bello natural») toma como punto de partida un hecho: el desprecio de la estética contemporánea por lo bello natural (Ronald Hepburn). En efecto, el imperio de lo bello artístico a lo largo de la tradición cultural occidental ha reducido la estética a una filosofía del arte, con la consecuente otorgación de un rango marginal y secundario a la reflexión sobre lo bello natural. La crisis ecológica de los años sesenta del siglo pasado ha introducido un evidente cambio de dirección en esta línea de pensamiento, ya que obligó a plantear la naturaleza «en sus términos mismos», revelando a la vez el antropocentrismo latente en toda teorización sobre la naturaleza, incluyendo la relativa a la estética. En esta sección, se plantea lo bello natural desde las reflexiones contemporáneas más influyentes e imprescindibles al respecto. Ronald W. Hepburn afirma la necesidad de pensar la naturaleza fuera del encuadramiento del arte, abriendo camino a una nueva área disciplinaria: la estética ambiental, a semejanza de Malcolm Budd, que contrapone aquí la apreciación estética de la naturaleza en cuanto naturaleza a la apreciación estética de la naturaleza como arte. Allen Carlson y Yuriko Saito defienden que apreciar la naturaleza no puede reducirse a la sensibilidad, sino que apela al factor cognitivo en cuanto modo de aprehensión que accede adecuadamente a lo bello natural, ya sea mediante la literacia ecológica (Carlson) o por la narrativa mítica que concede una espesura moral a la sensibilidad (Saito). A su vez, Arnold Berleant propone una estética del entorno y del compromiso en vez de una estética de la visualidad, adherente a una perspectiva que separa sujeto y objeto, afirmando la tesis de que el hombre y la naturaleza que lo rodea constituyen un continuum de recíproca transformación y afectación.

Ha de notarse que esta sección resulta doblemente crucial, puesto que si ates- tigua, por un lado, el movimiento teórico que busca la emancipación de lo bello natural respecto a lo bello artístico, por otro, anuncia una naturaleza que se comprende en íntima confinidad con el ser humano. En el preciso momento en que la crisis ecológica se presenta con un potencial de absoluta negatividad, dicho movimiento integra la tendencia reconfiguradora de la relación entre el ser humano y su entorno natural, proponiendo, a la vez, modos de superación de los dualismos que la tradición antagonizó desde la modernidad - hombre y naturaleza; sujeto y objeto; naturaleza y cultura; estética y ética.

«Entre estética y ética: el futuro del paisaje», la última sección, descubre la vía hacia una ontología del paisaje. No se trata aquí de pensar el concepto como «lo que ha sido» o "lo que es» en su peculiar ambivalencia entre naturaleza y cultura, campo y ciudad, creación y contemplación, sino en lo que será posiblemente. $\mathrm{Y}$ este «será» no se plantea aquí como futuro emergente de una linealidad temporal que se sucede a un pasado y un presente, sino más bien en cuanto horizonte de posibilidad humana deseable, atisbado como sentido y finalidad realizadora del ser. De este modo, el paisaje aparece como simbiosis, unidad fusional entre hombre y naturaleza (Arnold Berleant), experiencia irresistible y radical de fruición multiestésica, que apunta hacia la unidad del Ser (Rosario Assunto). El camino del Ser se plantea, asimismo, como camino del deber ser, y éste no resulta entendido como una imposición exterior, sino más bien como cuidado naturalmente emergente de un modo de ser auténtico, es decir, sensible. Así pues, la experiencia de lo bello natural puede (debe) (re)constituirse, en último término, como posibilidad ejemplar de la vida del hombre (Martin Seel). A los tres ensayos anteriores, se añaden las reflexiones de Luisa Bonesio, Paolo d'Angelo y Gonçalo Ribeiro Telles, que intentan 
trazar las líneas justificativas de la salvaguardia y protección de los paisajes ante la persistente amenaza resultante de la furia industrializadora y mercantil. Como si, cada uno a su estilo, intentasen contestar todos a Rosario Assunto, recordándonos, en el texto inicial de esta sección, "El paisaje y la estética», lo que parecemos olvidar, pese a ser evidente - sin la naturaleza nos moriremos.

No hay duda de que estamos en presencia de una obra de referencia, obligatoria, en el panorama de la reflexión estética y ética contemporáneas. Estructurada con coherencia y rigor, presenta una selección de textos fundamentales en el área de reflexión tematizada, organizados con arreglo a una lógica que los presenta confluyendo en un todo orgánico e interdependiente. Las traducciones sobresalen por ser irreprochables, lo cual contribuye a realizar una lectura accesible y nada aburrida. Aquí no se vislumbran debilidades y se reanuda el carácter relevante de esta antología, tanto en términos filosóficos como didácticos y pedagógicos.

En el preciso momento en que el progreso tecnocientífico y el frenesí consumista alcanzan el paroxismo de la desmesura y la deshumanización, resulta decisivo pensar lo humano en su naturaleza originaria — sensibilidad y afectividad. El paisaje, tomado como lugar en que habita el hombre, es, asimismo, êthos, es decir, acarrea no solamente una dimensión estética, al manifestar la ligazón sensible de las personas con su entorno natural, sino también ética, al favorecer la fidelidad y el respeto en cuanto a ese ser-con, esa ligazón existencial, que orienta al hombre hacia lo que él es esencialmente, ser-en-el-mundo. En este marco, esta obra antológica es, con toda justicia, fundamental, y no se dirige solamente a estudiosos con distintas formaciones (arquitectura, arquitectura paisajista, filosofía, ciencias ambientales, geógrafos, entre otros), sino también a todo aquél cuya formación e información le conceden una conciencia preocupada sobre el mundo en que se encuentra y es.

Tras esta exposición, se plantea una cuestión postrera: a fin de cuentas, ¿qué es el paisaje?

Y es en la respuesta de Adriana Veríssimo Serrão que encontramos, concentrada, toda la sustancia de esta obra:

Ni naturaleza ni cultura [...] sin duda que existe gracias a la presencia del hombre, que la identifica y la nombra, pero no como creador suyo [...] Hay un modo de ser específico del paisaje, que es sujeto y objeto, permanencia y movimiento, mutabilidad y persistencia. Material, favorece todas las sensaciones, sin dejar de ser intangible.

Maria José Varandas Centro de Filosofía de la Universidad de Lisboa Traducción de Maribel Sobreira y José L. Pérez http://dx.doi.org/10.5565/rev/enrahonar.167 
Veríssimo Serrão, Adriana (coord.) (2013) Filosofia e Arquitectura da Paisagem: Um Manual Lisboa: Centro de Filosofia da Universidade de Lisboa, 381 p. ISBN 978-989-8553-12-6

Esta obra es el segundo libro publicado en el ámbito del proyecto de investigación Filosofía y arquitectura de paisaje, que se está llevando a cabo en la Fundación para la Ciencia y la Tecnología, en el centro de Filosofía de la Universidad de Lisboa, en colaboración con el Centro de Estudios de Arquitectura Paisajística, del profesor Francisco Caldeira Cabral.

Con este libro, se pretende ofrecer una serie de artículos agrupados en siete secciones que contribuyan a establecer un diálogo sobre el concepto del paisaje en nuestro ámbito contemporáneo. El carácter de manual se comprueba desde la misma estructura.

En primer lugar, se aborda la cuestión del paisaje antes del paisaje $o$, lo que es lo mismo, se pretende dar una visión del concepto en el mundo antiguo y medieval. Maurizio Migliori y Agustin Berque, en sus textos respectivos, aproximan el concepto de paisaje y la visión de la naturaleza en Platón. Es interesante el análisis realizado por Berque sobre el espacio en relación con la chôra y El Timeo. Se continúa con una referencia a la filosofía de la naturaleza en Aristóteles de la mano de Giampaolo Abbate. Filipa Alonso es la encargada de tratar la problemática del paisaje en el mundo medieval, debido a la complejidad de elementos, escuelas y siglos que lo configuran como período histórico. Aborda la cuestión de cómo, en la Edad Media, aún no se maneja el término paisaje, en cambio, se emplean expresiones como orbis terrarrum, o 'círculo de tierra', que representa los espacios y las porciones de tierra conocidas por el hombre. Tomando la obra de San Francisco de Asís, Bacon o Escoto, percibe cómo el estudio de la naturaleza en el mundo medieval está relacionado con lo sobrenatural y lo divino. Sin abandonar esa visión del mundo medieval, Gregorio Piaia se encarga de hacer un análisis de las posturas de Hugo de San Víctor y Petrarca, partiendo de la postura del hombre ante una naturaleza creada por Dios. La sección se concluye con la aportación de Leonel Ribeiro dos Santos, que se encarga de tratar el tema de lo natural en la Ilustración, haciendo un análisis de las diferencias entre naturaleza y arte. Se sirve, para ello, de las nociones de Hegel en las Lecciones de estética y, además, del análisis de lo sublime para diferenciar y privilegiar la vivencia estética de la naturaleza frente a la experiencia estética del arte.

En segundo lugar, se abordan las expresiones culturales del paisaje. En esta sección, por un lado, se pretende establecer una comparación intercultural entre las cosmovisiones de Oriente y de Occidente, y, por otro lado, dar cabida a la multiplicidad de visiones sobre el paisaje en la cultura filosófica europea, ya sea como descripción geográfica del mundo o como representación artística (p. 10). La referencia al paisaje chino en relación con el europeo corre de la mano de Agustin Berque. Victor Conçalves, por su parte, toma a autores como Petrarca, Rousseau o Nietzsche para crear un discurso en el que se pueda relacionar el cuerpo y la naturaleza; desde la experiencia de Petrarca en el Mont Ventoux, pasando por las relaciones evidentes en los textos de Rousseau, como El Emilio, entre el hombre y la naturaleza, o la intensa actividad como viajero de Nietzsche en esa franja de la Europa central. Rainer Guldin lleva a cabo un interesante análisis de las representaciones de paisaje centrándose en el análisis de la representación de las nubes, mostrando ejemplos tanto de la pintura europea como de la pintura china. Por último, 
Dirk-Michael Henrich elabora un trabajo en el que pretende demarcar una relación entre el paisaje y la identidad europea, tratando de analizar la influencia del entorno y el clima en el condicionamiento político de Europa. Es interesante la introducción del concepto de Geofilosofía como una geografía filosófica o geografía física, como resultado de la emancipación y la especificación de las ciencias naturales. Dentro de este concepto, incluye a Nietzsche o Heidegger y, por extensión, a Deleuze y Guattari.

La tercera sección se adentra en el estudio de las interpretaciones del paisaje. Se divide en cuatro artículos, que van desde el sonido, la fotografía y el paisaje como arte hasta el turismo de paisaje. Comienza la sección con la contribución de Tiago Carvalho, que trata de introducir brevemente la relevancia de los aspectos sonoros del paisaje y de la arquitectura como contribuciones no despreciables para la relación vivencial de ambas tipologías de espacio. De aquí se pasa al análisis de Rui Cambraia sobre paisaje y fotografía. Se plantean una serie de cuestiones en torno a la fotografía que podemos resumir de la siguiente manera: jes posible fotografiar el arte, o solamente el objeto artístico? Esto lleva a la cuestión que se tratará de explicar: ¿es posible fotografiar el paisaje, o sólo la naturaleza? (p. 155).

En la cuarta sección, se discute sobre una cuestión que se mantiene en el tiempo: ¿`cómo conciliar la subjetividad de la actitud estética, basada en la sensibilidad, con la objetividad de lo moral, que implica, como consecuencia, la aceptación de la objetividad de la belleza? (p. 11). Luís Sá trata la cuestión tomando como punto de partida la constatación de un regreso de la naturaleza a la experiencia estética; percibe cómo, de alguna manera, en la historia reciente, se produce un regreso al modelo explicativo de la experiencia estética de Kant. Descubrirá los argumentos más comunes de autores como Allen Carlson, Arnol Berteant o Yuriko Saito para tratar el tema de la relación del hombre con la naturaleza y los vínculos que existen entre una estética de este tipo y la ética ambiental. Luisa Bonesio ofrece un texto en el que ilustra los diferentes planos de este movimiento teórico e intervencionista, desde el concepto fundador de lugar hasta el concepto de paisaje, entendido como identidad histórica y cultural, extrayendo de ahí la necesaria diferenciación de las singularidades territoriales en un mundo globalizado (p. 203). En su caso, Carmen Velayos analiza algunos argumentos de la ecoética contemporánea sobre la reflexión de los paisajes construidos en los que habitamos, destacando las posturas intermedias que se encuentran entre el intervencionismo extremo o la máxima conservación de los entornos y marcando la necesidad de intervenir con responsabilidad en nuestro entorno. Por último, María José Varandas identifica, a lo largo de su exposición, las principales cuestiones que se colocan en la ética ambiental. Hace uso de la argumentación de Krieger que apela por las intervenciones responsables en la gestión de los ambientes naturales, teniendo en cuenta la promoción del bienestar humano.

En la quinta sección, se agrupan una serie de artículos que tratan de afrontar la cuestión de la legalidad de la protección de lo "no humano", desde la clave antropocéntrica del deber de conservación y la armonía de los lugares. Ângela Delfino lleva a cabo un análisis del tratamiento jurídico de los conceptos de estética y de paisaje en los ordenamientos jurídicos nacional e internacional. Por su parte, Dora Lampreia se hace eco del Convenio Europeo de Paisaje (CEP), en el que, en el año 2000, se reconoce el paisaje como figura legal y confiere a las comunidades el derecho de vivir en un paisaje de calidad, así como el deber de participar activamente en las decisiones que acompañan a sus transformaciones. Trata de analizar la posición del paisaje en diferentes convenciones nacionales e 
internacionales. Para terminar la sección, Luísa Monteiro Franco analiza, en este capítulo, las diferentes leyes del ordenamiento territorial en el caso portugués. Estos surgen en 1934 y, desde entonces, tanto en el periodo predemocrático como en el democrático, se comprueba cómo se van ampliando.

En la sexta sección, agrupada bajo el título «Rediseñar el paisaje», se encuentran tres artículos que plantean la relación entre la filosofía de paisaje y las posturas de la arquitectura paisajística como un intento de renaturalización de los espacios vivos. En primer lugar, Pierre Donadieu habla sobre la posibilidad de crear un modelo de paisaje agrourbano, criticando el modelo urbano actual y ofreciendo una explicación a través de Agropolia, una ciudad utópica plenamente conectada con el mundo natural y agrícola.

Paula Gomes da Silva, a partir de la arquitectura de paisaje, propone un proyecto ecológico caracterizado por la creación de ecosistemas naturales y humanos informados por la ciencia ecológica. La sección finaliza con el artículo de Sebastião Ferreira de Almeida Santos, quien ofrece un proyecto en el que pensar el paisaje significa ser consciente de la multiplicidad del mirar, de la complejidad de los sistemas naturales que la definen, pero, sobre todo, actualmente, de la evolución de las sociedades y del mundo. Significa también redescubrir una acción y una idea al sentido de las palabras, una materia decisiva que nos envuelve como una nube.

La obra concluye con la séptima sección recogida bajo el título «Un concepto para el futuro». La sección comienza con el artículo de Adriana Veríssimo Serrão, en el que destaca el cambio de concepto en la reflexión sobre el paisaje que, si bien había aparecido como un acto de separación de la idea de naturaleza, ha venido a cumplir una función inversa con la revalorización de la misma: la de permitir lazos. Desde la imagen contemplativa del hombre sereno que pasea por la naturaleza contemplando su belleza o el magnífico espectáculo de su poder que se encargaron de estudiar los filósofos del siglo XVIII, hasta el desvanecimiento de los centros históricos y la expansión de suburbios sin identidad propia que generan como correlato paisajes degradados y un mundo rural igualmente dominado por el modelo de crecimiento industrial. Paolo d'Angelo se encarga de un texto en el que analiza las diferentes formas de repensar el paisaje, destacando cómo la noción de paisaje en un sentido estético ha sido objeto de numerosos ataques en las últimas décadas. Destaca la importancia de tratar el paisaje no como un panorama (ya que se trata de una imagen de la naturaleza), sino más bien como un lugar con identidad estética. La obra termina con la contribución de Arnold Berleant, quien plantea, en la misma línea que D’Angelo, que la idea común de paisaje, cuando se refiere a la visión de bellas escenas de la naturaleza terrestre, es un engaño. Y propone una alternativa más satisfactoria, que consiste en pensar el paisaje como un ambiente, un entorno, un medio ambiente. Esto permite que esta no sea ya principalmente visual, no sea una verdad de un objeto, sino que esté conectada y en continuidad con la presencia humana.

Este manual, en definitiva, recoge una serie de materiales de lectura obligada para aquel que quiera comprender y reflexionar sobre la situación actual en el pensamiento sobre las relaciones entre el hombre y la naturaleza a través de la construcción de una arquitectura de paisaje.

Carlos Javier Ferrero Martínez Universidad de Salamanca http://dx.doi.org/10.5565/rev/enrahonar.214 
Nogué, Joan; Puigbert, Laura; Bretcha, Gemma i Losantos, Àgata (eds.) (2013) Reptes en la cartografia del paisatge: Dinàmiques territorials $i$ valors intangibles Olot: Observatori del Paisatge, 226 p. ISBN 978-84-616-2668-7

\section{El paisatge i la seva cultura subcartogràfica}

L'Observatori del Paisatge de Catalunya acaba de publicar el llibre Reptes en la cartografia del paisatge: Dinàmiques territorials $i$ valors intangibles, una obra que forma part de la col-lecció «Plecs de Paisatge» i que s'inscriu a la sèrie "Eines». Fruit del seminari que el mateix Observatori organitzà a Tortosa al mes de setembre de l'any 2011, els textos aplegats en aquest volum magníficament editat corresponen parcialment a les diferents ponències que hi tingueren lloc. La sèrie de la qual forma part el llibre ens indica quina és la voluntat no només dels articles respectius, sinó també la idea que hi ha al darrere del seu objecte d'estudi: la cartografia del paisatge. Aportar eines o instruments per comprendre, planificar i gestionar més bé el paisatge és, si no vaig equivocat, la vocació general de l'obra. En aquest sentit, els textos no s'aparten gaire d'una idea instrumental de la cartografia: el mapa és una eina o un instrument que ens permet conèixer el territori («entendre la lògica del món», escriu Joan Nogué a la introducció), representar-lo i, d'aquesta manera, intervenir-hi activament o passiva. Com que el paisatge és un concepte complex, en la mesura que es tracta d'una relació entre parelles binàries històricament construïdes (subjecte i objecte, físic i espiritual, estàtic i dinàmic, cultura i natura, la part i el tot, raó i emoció, contemplació i acció, realitat i representació, material i immaterial, tangible i intangible, etc.), planteja certament un seguit de reptes que la cartografia difícilment pot superar. Minimitzar-los per mitjà de cartografies alternatives, dispositius electrònics nous o formes complementàries de visualitza- ció, entre d'altres, és l'objectiu d'algunes de les propostes dels autors i les autores d'aquest llibre.

Dit això, a continuació, voldria afegir-hi alguns comentaris que la lectura dels diferents textos m'ha suggerit. El llibre planteja un enunciat clar (com es pot representar cartogràficament els valors intangibles del paisatge?), i les respostes que ofereix s'hi ajusten i hi són coherents. Per tant, tot allò que jo hi pugui afegir es deu al fet que el paisatge és un concepte molt ampli, controvertit fins i tot. Les notes que segueixen s'han d'entendre, per tant, com el resultat d'una lectura en veu alta on conflueixen els reptes plantejats per l'Observatori i la meva idea d'allò que són (o poden ser) la cartografia i el paisatge.

Com he dit, en tots els escrits reunits en aquest volum, hi predomina la visió instrumental del mapa. La majoria dels textos comparteixen la idea segons la qual el mapa representa la realitat (ja sigui una realitat física o un valor intangible, com pot ser una emoció, un símbol o una representació sociocultural). Aquest punt de partida, però, ja és polèmic. Alguns geògrafs i historiadors de la cartografia han posat de manifest en els darrers anys que la cartografia no només representa una realitat preexistent, sinó que contribueix a construir-la. L'exemple més evident d'això són les identitats territorials; un aspecte, per cert, recorrent al llarg d'aquesta obra, en la mesura que es basen tant en elements materials com simbòlics. No obstant això, en cap capítol del llibre he llegit que la cartografia formi part d'aquesta construcció identitària d'un paisatge o d'un territori. Aquella tan sols es limitaria a restituir sobre el mapa alguna cosa ja present en el sí d'una geografia concreta. Un dels reptes 
de la cartografia del paisatge podria ser fer una història sobre com s'han construit cartogràficament les identitats paisatgístiques (i, de passada, les identitats culturals i socials). Sóc conscient que una empresa així desborda els propòsits d'aquesta obra. Amb tot, en alguns moments, hi he trobat a faltar un punt de vista més reflexiu i circular sobre la naturalesa dels mapes: la mateixa cartografia forma part de la percepció i representació social i cultural dels paisatges.

El llibre sorgeix d'una experiència i d'una pràctica concreta. Això podria explicar l'absència d'una reflexió de caràcter més històric o teòric sobre la cartografia $\mathrm{i}$ el paisatge. Aquesta experiència és prou explícita en el títol d'un dels subapartats de l'article de Pere Sala: «Cartografiar el paisatge des de l'experiència dels catàlegs de paisatge» (p. 16). Els catàlegs de paisatge són uns instruments que introdueix la Llei $8 / 2005$, de 8 de juny, de protecció, gestió i ordenació del paisatge de Catalunya, amb la finalitat d'introduir criteris paisatgístics en el planejament territorial, especialment en els plans territorials parcials. És per tant en aquest marc on s'han de situar les diferents propostes i consideracions del llibre. Això no treu, però, que puguem ampliar el context semàntic de les paraules en joc.

Començant pel títol, per exemple. Només des d'una perspectiva actual es pot plantejar una "cartografia del paisatge» (i els reptes que comporta) sense veure-hi d'entrada una contradicció de fons. Històricament, però, al voltant de les expressions cartografia i paisatge, s'hi concentren aspiracions i necessitats completament oposades. Es podria resumir així: originàriament, el paisatge ja és en si mateix una sortida als «límits» que la cartografia imposa. Uns límits que s'han d'interpretar, al mateix temps, en un sentit polític i epistemològic. Paisatge i carto- grafia són dos models geogràfics oposats (tot i que avui en dia ens puguin semblar complementaris). Si entenem el paisatge com una proposta epistemològica, com un model cognitiu, aleshores podem considerar-lo com una via alternativa o reactiva a la del mapa, a la projecció cartogràfica moderna. Simplificant una mica les coses, podríem dir que mentre el mapa és el model de coneixement propi de la Illustració, la materialització del somni de la raó (universalitat, abstracció, anul-lació del mite i de tot allò que voreja el subjecte; en altres paraules: el coneixement del que és clar i distint), el paisatge en constitueix la reacció romàntica (primacia del sentiment, de l'univers oníric, de tot allò que és nebulós i confús). El paisatge, en aquest sentit, sorgeix justament a partir dels límits del coneixement cartogràfic. Per tant, no és que existeixin reptes per a la cartografia del paisatge, sinó que tota cartografia planteja reptes i límits cognitius insuperables.

De la mateixa manera, si entenem la introducció del paisatge en el camp de la geografia com una estratègia política per desautoritzar les representacions cartogràfiques del poder estatal (aquesta és la lectura que ha fet de la història del paisatge el geògraf Franco Farinelli), aleshores podem interpretar el mapa i el paisatge com dues manifestacions antitètiques: el mapa no només representa el territori, sinó que també representa el poder (l'Estat, l'Administració) ${ }^{1}$. El paisatge, d'altra banda, seria un moviment subterrani, que no es deixa atrapar per la representació cartogràfica; el paisatge transcendeix els límits objectius i interns del mapa (d'aquí ve el problema dels límits que tan bé ha exposat Pere Sala al seu article). Per dirho grollerament, el paisatge és un contrapoder. Dit d'una altra manera: el paisatge forma part d'una cultura «subcartogràfica» (de la mateixa forma que parlem

1. Franco Farinelli (2013), «Historia del concepto geográfico de paisaje», a Bernat Lladó, Franco Farinelli: Del mapa al laberinto, Barcelona, Icaria, 128-149, Espacios Críticos. 
d'una cultura suburbana per referir-nos a una cultura que no es pot institucionalitzar, que no és l'oficial o dominant). És quelcom que sempre va davant, que s'anticipa i escapa al control imaginari de l'Estat. És efímer i voladís (i fixem-nos que un dels reptes de la cartografia del paisatge és esbrinar com es pot anticipar, com pot atrapar allò que sempre s'escapa: "cartografiar els paisatges que vénen", segons Pere Sala; cartografiar els "paisatges tendencials», segons Benedetta Castiglioni i Viviana Ferrario). D'aquí ve el valor estratègic de l'horitzó en la seva representació. Que recentment s'insisteixi a identificar paisatge i societat civil podria ser un indici de fins a quin punt aquesta lectura és correcta. Amb tot, que jo sàpiga, molt pocs autors han vinculat la història del paisatge amb les diferents institucions polítiques de la nostra tradició social i cultural. El fet que la separació entre estat i societat civil (una separació que, si no vaig equivocat, no és anterior a Hobbes) sigui contemporània a l'aparició del paisatge com a categoria estètica, ja és un bon punt de partida. Dit d'una altra manera: si a l'època clàssica no emergeix la idea de paisatge, és sobretot perquè estat i societat civil són la mateixa cosa, perquè coincideixen. Seguir aquesta interpretació ens permetria sortir del paradigma estètic del paisatge; un paradigma, per cert, que, en el cas dels estudis de paisatge, em sembla que ha quedat massa encotillat.

Fixem-nos, per exemple, en què entenem normalment per valor estètic del paisatge. En la majoria de textos, aquest està relacionat «amb la capacitat que té un paisatge per transmetre un determinat sentiment de bellesa» (segons la referència de Jordi Bellmunt, p. 43). És cert que, quan l'estètica deixà de referir-se al coneixement sensible, passà a delimitar el que és bell, però el camp de l'estètica no ha deixat d'ampliar-se. Eugenio Trias va escriure fa un temps, al llibre Lo bello y lo siniestro (1982), això que segueix: «Lo sublime y lo siniestro nos aparecen ahora como categorías estéticas que enriquecen el inventario categorial estético, ensanchando el marco clauso en que la estética se hallaba circunscrita hasta mediados del siglo XVIII, fundamentalmente hasta Kant: el marco estricto y limitativo de lo bello». Fa un temps, el sublim formava part del mateix camp semàntic que el paisatge $i$, fins a cert punt, s'entén que hagi desaparegut del llenguatge de la geografia: allò incommensurable no es pot cartografiar (no existeix un patró de mesura per fer-ho). El més sorprenent és, però, que encara no s'hagi incorporat al catàleg de paisatges la categoria del que és sinistre, funest. En l'excel-lent capítol de Josep Maria Mallarach, «De la geografia sagrada a la cartografia del patrimoni espiritual natural: experiències i reptes», hi trobo una mancança: no hi ha referències a paisatges sagrats actuals o potencials. Segurament, es deu al fet que identifica el món sagrat amb les tradicions religioses més o menys institucionalitzades i amb experiències espirituals força codificades. Ara bé, podríem identificar paisatges que poden tenir alguna funció sagrada (ritual, sacrifici, comunió entre els vius i els morts, transcendència), sense cap relació amb formes religioses o espirituals establertes? No sóc cap expert en aquesta matèria i espero no dir cap disbarat, però penso que els anomenats «punts negres» de les carreteres catalanes podrien formar part d'una nova geografia sagrada, d'un nou paisatge funest. No voldria ser frívol, però potser podríem aïllar alguns elements d'aquesta història religiosa (sacrificis, ofrenes, relíquies i commemoracions; divinitats, fins i tot, a la velocitat, la tecnologia, la llibertat?), a fi d'entendre el paper que aquests paisatges poden tenir en la nostra societat.

$\mathrm{Si}$ en la pràctica totalitat dels articles hi he trobat a faltar una reflexió més complexa del paper de la cartografia en la construcció del paisatge, els dos articles on, d'una forma més decidida, aposten 
per introduir les noves tecnologies en la comprensió i la intervenció del paisatge m'han deixat perplex davant la manca d'un raonament dialèctic sobre els nous dispositius cartogràfics. Tant el text «La realitat mixta en la cartografia: Noves tecnologies per als mapes del futur», de Volker Paelke, com «Mapes de paisatges emocionals», de David Casacuberta, m'han sorprès per la confiança envers les possibilitats que ofereixen les noves tecnologies. D'entrada, he de dir que, en aquest camp, sóc un intrús, a més d'un escèptic. Però no crec que s'hagi de ser un expert per adonar-se no només dels beneficis que aquestes tecnologies aporten, sinó també dels seus perills. Sovint em sorprèn la facilitat amb què s'oblida que la cartografia és, fonamentalment, una tecnologia militar. Quan Paelke ens parla dels avantatges de la "realitat mixta» i la visualització subsuperficial, no puc deixar de pensar què hauria passat si els avions alemanys i italians que sobrevolaren els diferents paisatges de la Guerra Civil haguessin estat equipats amb aquests dispositius. En el context del debat que planteja el llibre, l'article de Paelke hi aporta idees noves. Ara bé, una altra opció a l'hora d'observar els reptes de la cartografia de paisatge seria preguntar-se per les conseqüències no previstes o no reconegudes de la «realitat mixta».

D'altra banda, Casacuberta ens presenta el projecte Rosespèdia, l'enciclopèdia participativa del patrimoni cultural de Roses. Per mitjà d'aquest projecte, es vol ampliar el paisatge turístic de Roses, fins ara circumscrit a la franja litoral. Per ferho, es vol recuperar el patrimoni cultural de l'interior, tot vinculant-lo a les experiències emocionals que aquest pugui generar. Per això, Casacuberta ens parla de «mapes emocionals». Segons ell, la idea de «mapa emocional» té els seus precedents en el món de l'art: en la psicogeografia dels situacionistes i de Guy Debord, d'una banda, i en l'obra de Christian Nold, de l'altra. Sorprèn, d'entrada, la re- ferència al situacionista francès, ja que aquest autor també és conegut per la seva incisiva crítica a la societat de l'espectacle. És més, no crec que es pugui desvincular aquesta crítica de la seva activitat artística $i$, en concret, del famós mapa The Naked City. En aquest sentit, i per molt lúdica que sigui la proposta Rosespèdia, no tinc gaire clar que aquesta no fos inclosa per Debord dins la categoria genèrica d'espectacle. El problema no és, evidentment, el projecte Rosespèdia en si, sinó voler-lo justificar amb experiències que, al meu entendre, no tenen res a veure o són molt lluny de la seva intenció inicial.

Igualment sorprenent és la valoració que Casacuberta fa del projecte artístic de Nold i les seves aplicacions possibles. Escriu entusiasta: «Podem imaginar-nos un futur no gaire llunyà en el qual els arquitectes [puguin] crear un urbanisme més subjectiu i emocional» (p. 174). Amb tots els respectes per la figura i l'estil arquitectònic personal de Michael Jackson, però no em sé imaginar les conseqüències que podria tenir aplicar els principis urbanístics subjectius de Neverland a les nostres ciutats (per posar-ne només un exemple agafat al vol). En relació amb les emocions, tampoc no estic gaire segur dels beneficis que en podríem treure d'un urbanisme més emocional. De fet, això ja existeix: alguns serveis de restauració estan creant paisatges en què les emocions hi són manipulades, sovint de forma inconscient, per estimular el consum (per exemple: olors associades a determinats productes alimentaris).

El projecte Rosespèdia, tanmateix, sorprèn igualment per altres aspectes relacionats amb l'ús de la tecnologia; per exemple: quan afirma que la captura via mòbil dels codis $\mathrm{QR}$ «és una tecnologia molt activa, la qual cosa significa que l'usuari ha de buscar activament els codis» (p.180). No voldria ofendre ningú, però buscar un codi $\mathrm{QR}$ pot ser tan actiu o tan passiu com canviar el canal d'un televisor. Un altre problema d'aquest 
projecte, al meu parer, és el de la informació; concretament, el filtre i la jerarquització. Per exemple, ens diu Casacuberta: "per acompanyar les descripcions històriques d'una casa de pagès, un usuari podria afegir-hi una llegenda local sobre el fantasma d'algú que suposadament va viure allà cent anys abans» (p.182). Si això és així, com diferenciem realitat i ficció (una distinció ja de per si prou delicada en el camp de la historiografia)? A més, si acceptem que es tracta d'una llegenda, com ho sabem que forma part de la cultura oral de Roses (i no una invenció espontània d'un prosumer)? Tampoc és un fet que s'hagi de menystenir el límit de la informació: quan ens connectem a Rosespèdia, continua Casacuberta, «entrem en un territori il.limitat d'informació». Avui en dia, però, el problema no és justament com es pot delimitar tota aquesta informació? Tot plegat fa que el projecte Rosespèdia es converteixi, com intencionadament el defineixen els seus promotors, en un safari cultural en el qual podrem conèixer d'una manera «divertida» el patrimoni cultural de Roses.

No en tinc cap dubte que conèixer el patrimoni cultural i natural d'un lloc, així com el seu paisatge, pot ser una cosa «divertida». Però també estic cada vegada més convençut que requereix esforç, que representa una gran dificultat. Conèixer, interpretar, llegir, representar un paisatge és una tasca complexa i difícil. En aquest sentit, al meu parer, allò que s'ha de transmetre als visitants o turistes és justament aquesta dificultat. Conèixer el lloc requereix un treball previ i posterior important; incentivar aquest treball hauria de ser l'objectiu d'una visita presencial a un paisatge determinat. No sabria imaginar-me, per exemple, el famós episodi de Stendhal a la ciutat de Florència l'any 1817, que marca l'inici d'allò que avui en dia podríem anomenar una relació emocional amb el paisatge, si aquell senzillament hagués anat equipat amb dispositius mòbils per capturar codis QR. Allò que trasbalsa Stendhal, allò que li fa perdre l'equilibri i el deixa completament impactat davant del patrimoni renaixentista i medieval de la ciutat italiana és, sense dubte, el bagatge cultural que porta a sobre, el coneixement previ de la història de la ciutat. El grau d'implicació que es pot tenir amb el paisatge, segons el meu punt de vista, és més alt com més referències prèvies es tenen d'un lloc. El paisatge no és un fet immediat i espontani; com més ric és el saber que nosaltres incorporem (sobre la geografia, la història, l'art, la cultura, etc.), més ric és el paisatge resultant, és a dir, el paisatge que observem. Em sembla que aquest és el treball pedagògic que s'ha d'incentivar al voltant del paisatge.

El llibre Reptes en la cartografia del paisatge representa una gran aportació al debat actual al voltant de paisatge. Com que aquest és, al mateix temps, matèria i representació, qualsevol política paisatgística també ha de tenir en compte tot allò que inclou els imaginaris, el món de les imatges. La cartografia forma part d'aquest món, per bé que resta encara limitada. Els diferents textos aporten, sense dubte, algunes propostes molt interessants, encara que, segurament, no esgoten totes les possibilitats. El gran mèrit d'aquesta obra és que deixa obert el debat. Amb tot, no respon la gran pregunta de fons que suscita el llibre (de fet, no la planteja): quin valor o quin ús polític o econòmic (a més de social i cultural) tenen avui en dia els aspectes intangibles del paisatge perquè li dediquem un llibre?

Bernat Lladó Mas

Grup d'art geogràfic (Sa)badall http://dx.doi.org/10.5565/rev/enrahonar.168 
García Gómez-Heras, José María (2012)

Bioética y ecología: Los valores de la naturaleza como norma moral

Madrid: Síntesis, 224 p.

ISBN 978-84-9958-942-8

En esta obra, el autor, fiel a su sensibilidad y a la consideración mostrada respecto a la naturaleza y al medio ambiente, nos invita a analizar la cuestión de los valores morales, reconstruyéndolos en vinculación con el lenguaje, la sociedad $y$, por supuesto, en su relación con la naturaleza. Examinando si la naturaleza es o no es portadora de valores, se introduce en su validez como fuente de moralidad para los actos humanos. El autor hace este ejercicio como un esfuerzo por volver a los orígenes del término bioética tal como la planteó Potter (1971), como una disciplina puente entre la biología y la axiología, entre las ciencias de la naturaleza y las humanidades; en tiempos en que esta disciplina parece haberse encapsulado en debates de raigambre biomédica.

$\mathrm{Y}$ es que no se puede estar más de acuerdo con dicho planteamiento, si pensamos en las muchas voces que se han alzado a favor de una ampliación de la mirada de la bioética y su efectiva vuelta hacia el resto de entidades vivas, porque no solamente los seres humanos y los problemas biomédicos de la ciencia y la técnica son los que caben en su campo. Sucede más bien que la ciencia y la técnica influyen de manera positiva y negativa no sólo en las personas, sino también en el resto de individuos animales, actuales y futuros, con los que compartimos el planeta, $y$, por descontado, también con el medio ambiente que a todos nos rodea y que será herencia de las generaciones futuras de humanos y no humanos. Este énfasis propuesto por el autor lo hace de total actualidad para la discusión en la bioética, especialmente porque bebe de las fuentes de la ética y de la ética aplicada para el planteamiento y el análisis del tema.
Gómez-Heras divide su libro en dos partes. La primera está relacionada con «Hechos y valores» y la segunda se titula «Bioética, valores morales y valores de la naturaleza». En la primera parte, el autor describe la tensión entre las posibilidades de la técnica («poder hacer») y la legitimidad moral de esas posibilidades («deber hacer»), ejemplificando esta tensión de manera muy didáctica con ejemplos casuísticos al uso en comités de ética asistencial, para entrar en las grandes preguntas éticas que nos plantean las posibilidades tecnocientíficas en nuestra vida cotidiana. En la segunda parte, el autor entra en la cuestión de los valores morales, su concepto, estatuto, situación y naturaleza y en cómo y por qué son fuente de obligación moral.

Para relacionar la primera y la segunda parte de la obra, el autor nos conduce al tema central, que es la relación entre hechos científicos y valores como ámbitos heterogéneos de la realidad. Toma este punto de partida ante lo que él denomina «estrechamiento del mundo moral» a lo largo de la modernidad, a causa del concepto de saber y la práctica científica. En el estado actual de cosas, los hechos remiten a lo dado en la realidad objetiva - y son, por lo tanto, cognoscibles científicamente-, mientras que el valor - como concepto que se inició en el ámbito de la economía (como precio o suma de dinero que se paga por algo a lo que se tiene aprecio) - se instaló en la filosofía para "designar las cualidades positivas o perfecciones de las personas, de las cosas y de las acciones» ( $\mathrm{p}$. 75). Los valores, entonces, situados siempre en la esfera de la necesidad humana, se transformaron en deseables porque se los estima para vivir. Y, por ello, la teoría 
del valor y de cómo se incardinan éstos en la vida humana, al tiempo de cómo hacemos para estudiarlos de manera científica, se transforman en el hilo conductor de la obra.

Según Gómez-Heras, la trilogía compuesta por los científicos Bacon, Galileo y Descartes estableció el mecanicismo como una herramienta que reduce al mundo y al ser humano - especificaría yo, además, a los animales no humanos y a la naturaleza - en una máquina inmensa, con la técnica como el gran artilugio posibilitador de realidades. En la operación cientificista y mecanicista de la técnica, ésta quedó desprovista de valores y se inauguró una era en que hechos y valores son entidades totalmente separadas e independientes una de otra: la ciencia es axiológicamente neutral y, por lo tanto, no acepta cuestionamientos éticos. Lo mismo sucedió con la filosofía tradicional, influenciada por la herencia de Kant, que separó la mente de la realidad, escindiendo así los hechos de la naturaleza del mundo de los valores. Para neopositivistas y filósofos analíticos, los valores no son más que contenidos mentales subjetivos que se expresan en el lenguaje, no aportan conocimiento alguno y su lugar sería la metaética (como análisis del discurso moral, no del contenido de las reglas morales). Es así como la gran pregunta pendiente de respuesta de parte de la ciencia y la técnica se relaciona precisamente con la legitimidad moral de llevar sus posibilidades potenciales al campo de lo real.

En bioética no se carece, lamentablemente, de ejemplos sobre estas ocasiones en que las posibilidades técnicas no se han acompañado del análisis ético debido sobre su realización: las investigaciones llevadas a cabo en personas consideradas «inferiores» (los prisioneros de los campos de concentración en la Segunda Guerra Mundial, los hombres afroamericanos en el experimento de Tuskegee, por mencionar algunos de ellos) fueron actividades donde las «promesas» de la ciencia y la técnica ni siquiera cuestionaron la legitimidad moral de experimentar sobre estas personas sin su conocimiento ni consentimiento. El mismo reclamo se puede plantear ante las posibilidades técnicas de la modificación de los animales no humanos (por ejemplo: las modificaciones genéticas para acentuar ciertos caracteres deseados en el ámbito de las mascotas o la agroindustria, la clonación, la manipulación genética para transformarlos en $m a-$ terial biológico especializado para la investigación, etc.). Sin embargo, cuando se trata de los animales no humanos, la pregunta por la moralidad de la intervención de la técnica ni siquiera llega a plantearse. Más bien se concluye inmediatamente sobre la utilidad que dichas intervenciones tendrán para los fines humanos, con lo que la subsidiariedad moral de los animales jamás se pone en entredicho desde las concepciones antropocéntricas de la ciencia y la técnica.

Nos dice Gómez-Heras que, para volver a poner a los hechos en relación con los valores y reanalizarlos para desarrollar una bioética más inclusiva, hemos de integrar necesariamente estos valores en el mundo de la cultura y de la naturaleza, además de buscar su estudio y su relación con la ciencia o la técnica. Aquí, para facilitar la comprensión de los hechos de la cultura, la naturaleza y el hombre, recurre a la sociología explicativocomprensiva de los «tipos ideales» de Max Weber. Estos tipos ideales describirían la realidad, sin tener correlato empírico en ella (por ejemplo: conceptos como autoridad, burocracia, capitalismo, etc.), y hacen posible un análisis causal y explicativo de los valores, las preferencias o los intereses éticos, políticos o ideológicos de la sociedad. La acción racional con arreglo a valores weberiana, motivada por la creencia en determinados valores, permite seleccionar los hechos relevantes y establecer relaciones entre ellos. También introduce el análisis valórico de la mano de la teoría crítica de la Escuela de 
Frankfurt. Con su interés emancipatorio de la ciencia positivista tradicional (que disocia sujeto y objeto y los valores son relegados al ámbito irracional de lo emocional), introduce la ética en la creación del conocimiento y la filosofía social. Desde este punto de vista, las ciencias sociales - y, con ella, la ética y la bioética- requieren que la racionalidad instrumental de la ciencia y la técnica se subordine a la racionalidad final (racionalidad con arreglo a valores en Weber) y reconoce en su seno la importancia de los juicios de valor y la ponderación ética de los actos científico-tecnológicos, donde cada mejora científico-técnica debe pasar un escrutinio ético que pondere la moralidad de su ejecución y las consecuencias de ésta. Al mismo tiempo, restituye el pragmatismo de Dewey, reconociendo la génesis de la acción moral en las interacciones sociales y la acción social comunitaria, donde la educación es una potente herramienta de cambio, que enriquece las perspectivas de la ética y la bioética a nivel global.

Tanto para la Escuela de Frankfurt como para Dewey, la educación para la formación y la transformación política de la sociedad y el entorno son claves en la relación entre hechos y valores. Educar ciudadanos equivale a construir valores $y$, para Gómez-Heras, pasa necesariamente por una revinculación con la naturaleza. A día de hoy, el racionalismo crítico y la exclusión de los valores de la esfera científico-técnica es un hecho de gran importancia para la bioética, cuando, en palabras del autor: «el método en forma de técnica adquiere mayor importancia que la misma enfermedad, que la paciente enferma y que la persona del médico, perdiéndose de vista las dimensiones morales del acto terapéutico» (p. 111). La bioética médica se vacía de elementos axiológico-valorativos para derivar en técnica, donde prevalecería la razón instrumental por encima de la racionalidad valorativa. Éste sería, para el autor, un vicio lamentable de la filosofía tradicional —y también de la bioética-, pues separa los hechos de la naturaleza del mundo de los valores, circunscribiéndolos a la objetividad de la ciencia y a la subjetividad de los individuos, respectivamente. En el discurso actual de la bioética global, éste es un punto especialmente relevante, particularmente en lo que respecta a la educación en bioética y a la construcción de un vínculo entre ciencia y sociedad. De esta manera, para el autor, relacionar hechos con valores requerirá vincularlos a la naturaleza y entender el rol fundamental que desempeñan en la vida de la humanidad y de la sociedad.

La naturaleza, considerada como res extensa, es un objeto más de manipulación, control y dominio científico-técnico, gobernado por los intereses fundamentales de los seres humanos. Para el autor, el tránsito del mundo físico (natural) al mundo del valor es lo que se debe explicar para superar esta consideración de la naturaleza, vinculando ciencias naturales, conciencia subjetiva, historicidad y democracia. Siguiendo a H. Rolston, el autor argumenta que la naturaleza sería fuente de valor intrínseco y extrínseco, porque sus cualidades están en ella misma, presentes objetivamente de modo universal, y porque requiere de una(s) subjetividad(es) para conocer y estimar esas cualidades presentes en ella. El autor reconoce el prejuicio antropocéntrico que rezuma el subjetivismo de la modernidad, donde el acto de valorar pertenece únicamente a los humanos - que valoran a la naturaleza instrumentalmente desde baremos económicos, científicos, emocionales, espirituales, etc.- contra el que argumenta que los procesos biológicos de los individuos implican operaciones axiológicas aunque sean inconscientes, remarcando y dando importancia a la entidad de los animales no humanos como centros valoradores. Así, humanos y animales valoran, con lo cual la valoración no sería una capacidad antropocén- 
trica, sino biocéntrica y zoocéntrica. $Y$ con el sólo hecho de que alguien -humano o no humano- valore, emergen las ideas de responsabilidad y deber (lo que tomaría el lugar de la «ley moral» de la naturaleza).

Por el mismo motivo, las especies también tendrían valor intrínseco y extrínseco, y los ecosistemas serían portadores de valor intrínseco, porque sus componentes son relevantes para la comunidad biótica general. Para GómezHeras, si la naturaleza es portadora de valores intrínsecos objetivos, y la intervención humana (agencia moral) introduce elementos como la razón, la libertad, la responsabilidad y el lenguaje, entonces los valores de la naturaleza adquieren rango de valores morales. Aquí sitúa la contribución de la ética ambiental y la bioética «explicitar la contribución de los factores antropológicos que forman parte de la génesis del acto moral: vivir, conocer, deliberar, estimar, decidir, elegir, legislar; con lo que los cuatro sectores donde existen tensiones: la cultura, la ciencia, la política y la libertad de conciencia colaboran en la construcción del mundo moral» (p. 190191). A la visión antropocentrista utilitaria opone la axiología medioambiental de los valores objetivos intrínsecos de la naturaleza, que dan valor a la vida, a la biodiversidad, al equilibrio biótico, a la protección de especies, a la estabilidad del clima, a posibilitar la vida de las generaciones futuras humanas y no humanas, etc. En este volumen, el análisis y la propuesta para superar el enclaustramiento biomédico de la bioética se logra reafirmando y considerando positivamente a la naturaleza y al ser humano como un elemento componente de ella. Y, a mi juicio, la mayor aportación de esta propuesta es incardinar la bioética en un proyecto social y educativo para la democracia, que reivindica el conocimiento de las ciencias naturales y las humanidades para la construcción de una bioética global amplia y que considere no sólo al hombre, sino también al resto de entidades vivas con las que el ser humano comparte el planeta. Este es, hoy en día, uno de los grandes desafíos que se plantean a la ética aplicada y, con ella, a la bioética global.

\section{Referencia bibliográfica}

PotTer, Van Rensselaer (1971). Bioethics: Bridge to the Future. New Jersey: Prentice Hall.

Fabiola Leyton

Universitat de Barcelona http://dx.doi.org/10.5565/rev/enrahonar.239 
García Gómez-Heras, José María (2012)

Debate en bioética: Identidad del paciente y praxis médica

Madrid: Biblioteca Nueva, $331 \mathrm{p}$.

ISBN 978-84-9940-431-8

La bioética forma parte de la reflexión de muchos problemas que acucian a nuestra sociedad. Eutanasia, consentimientos informados, abortos, diagnósticos preimplantacionales, etc. son algunos de los ejemplos que trufan casi diariamente periódicos, informativos y debates más o menos acalorados en tertulias televisivas y radiofónicas. Habitualmente, la bioética se ha considerado una parte de la medicina. Stephen Toulmin fue más allá cuando afirmó que la medicina había salvado a la ética. Como quien salva a un náufrago con un salvavidas, la medicina había sacado a la ética de la especialización filosófica de la que forma parte. Ahora bien, que la bioética trate problemas de índole hospitalario es una verdad incontestable. Es más, la bioética ha nacido y ha crecido de la mano de la praxis médica, y la institucionalización de los comités de bioética parece reforzar aún más esta idea. No obstante, José M. ${ }^{a}$ García Gómez-Heras, como catedrático de Filosofía Moral y Política de la Universidad de Salamanca, conoce bien el terreno y acertadamente, pone de relieve una cuestión fundamental en relación con la bioética: recuperar la estructura filosófica de la misma y que nunca debió perder. Esta tarea es necesaria, puesto que cada controversia a la que se enfrenta la bioética esconde diferentes cosmovisiones no explicitadas, cada postura lleva implícitas diferentes antropologías, y es aquí donde el filósofo puede aportar su contribución haciéndonos conscientes de los conceptos básicos que a menudo se dan por supuestos, como el bien, persona o autonomía, entre otros, y la hermenéutica como herramienta filosófica con la que acercarnos a la bioética y a los problemas que suscita. Relación que se justifica extensamente en la segunda parte del libro.
Nuestra época actual ha cambiado significativamente desde que Tom L. Beauchamp y James F. Childress formularan sus cuatro principios básicos de la bioética estándar. A saber, los principios de autonomía, beneficencia, no maleficencia y justicia dominaron la bioética estándar desde que fueran formulados allá por 1979. Aunque estos principios y su aplicación no estuvieron exentos de conflictos, la colisión entre ellos se resolvió mayoritariamente en beneficio del principio de autonomía. Sin embargo, actualmente, el ser humano se enfrenta a un proceso de globalización que reclama una ética transcultural de mínimos que nos permita solventar problemas cada vez más globales, como, por ejemplo, el sida o la gripe aviar. Estas dificultades son difícilmente resolubles aplicando únicamente este principio, puesto que son cuestiones que nos afectan como miembros de un mundo cada vez más interconectado, por lo que la bioética está llamada a romper sus cadenas y, lo más importante, debe ser repensada desde nuevos horizontes. Este es el objetivo de Gómez-Heras: reflexionar sobre la bioética y sobre los presupuestos científico-metodológicos que la sustentan, puesto que ya ha llegado a su mayoría de edad. Para ello, recorre, a lo largo del libro, a diferentes cuestiones que entrelazan a la bioética con la ética $y$, por ende, con la filosofía. A lo largo de diferentes capítulos, el autor despliega una serie de relaciones entre ambas disciplinas, tarea de la primera parte del libro.

El proceso de globalización al que está sometida nuestra época es imparable y nuestra sociedad cada vez es más plural, tanto desde el punto de vista cultural como ideológico. Esta pluralidad va más allá del manido ejemplo usado en mu- 
chos casos del testigo de Jehová que no quiere que le transfundan por motivos religiosos. A esta multiculturalidad, se le une una característica de nuestra sociedad, que es el dominio del ideario científico-tecnológico. Este segundo punto recoge unos de los problemas en filosofía de la ciencia más importantes: ¿puede y debe el filósofo decirle al científico lo que puede o no puede hacer?

Desde un punto de vista kantiano, la respuesta es inmediata. No sólo puede, sino que debe, ya que los principios éticos están por encima de cualquier situación particular o casuística. Sin embargo, la bioética actual ha virado hacia una ética de pie de cama. Es decir, una ética basada en casos, una ética que, como bien apunta el autor, es de abajo a arriba. Este tipo de bioética, promovida quizás por la abundancia de casos que se discuten propiamente en los comités de bioética, parece la única posible en una sociedad cada vez más pluralista y donde una ética de mínimos practicada en la actualidad, basada en valores comunes, se torna cada vez más difusa y utópica y es que ¿cómo encontrar estos valores entre una sociedad cada vez más diversificada? La solución que ofrece el autor es sencilla y clara: hay que priorizar el principio de justicia. Defender la igualdad de todos los ciudadanos, así como la equidad y la justicia. Repensar la bioética en términos de solidaridad mundial en defensa de la igualdad y de la libertad. Es necesario, pues, poner límites a la casuística acusada de relativismo y rescatar la universalidad de la bioética. Y es que todo problema bioético está relacionado con los principios generales de la ética. La bioética necesita su propio discurso del método y ésta es la tarea de Gómez-Heras.

El autor recurre a Habermas para diferenciar entre tres tipos de ciencia: la empírico-analítica, la histórico-hermenéutica y la ético-social. La bioética, en su reinserción en la ética filosófica, se centra en los tres elementos, puesto que cada caso cuenta con los datos aportados por la ciencia, la identidad del paciente o su mundo vivido y los condicionantes sociales. Es aquí donde Gómez-Heras despliega magistralmente las relaciones de la bioética con los tres tipos habermasianos de ciencia, haciendo un recorrido exhaustivo entre los elementos de la bioética y los diferentes tipos de ciencia anteriormente mencionados.

$\mathrm{Y}$ es que los asuntos de la bioética comparten el sentido de la sociedad y de la cultura a la que pertenecen, metodología dialéctica. Los valores que motivaron las decisiones tomadas fueron diferentes en un estado nazi o en la dictadura marxista. El positivismo en bioética aborda los casos con alguna problemática moral en forma de interés por los datos empíricos. Esta última perspectiva ha tenido bastante éxito en los comités de bioética, y es que, con ella, se solventan los dilemas morales apelando únicamente a los aspectos técnicos. Gómez-Heras remarca el uso de la casuística en bioética para reafirmar el uso de una ética a pie de cama. Sin embargo, y eso es un acierto por parte del autor, él mismo hace uso de casos para remarcar las carencias de los enfoques en bioética atendiendo únicamente a su perfil dialéctico o empírico. El autor remarca la importancia de la hermenéutica para ayudarnos a resolver muchos problemas en bioética donde se relacionan hechos, valores, datos y convicciones.

La hermenéutica nos permite comprender e interpretar el mundo vivido. Tradicionalmente, ha sido utilizada para explicar experiencias históricas consignadas en textos. Y es que sus estrategias son también aplicables a la comprensión de situaciones humanas que necesitan de una interpretación. Ciertamente, el mundo vivido por el paciente permite comprender e interpretar su punto de vista sobre múltiples datos de su situación. Este mundo se expresa y se expone mediante el lenguaje. Parte inextricable de la relación entre médico y paciente, cuya máxima 
expresión sería el consentimiento informado. Gómez-Heras es claro, la hermenéutica interpreta coincidencias y discrepancias entre la conciencia (ética), el derecho (leyes) y los hechos (ciencia). El paciente narra la vida ante el médico que escucha y crea el espacio de la medicina narrativa que se opone a la medicina basada en la evidencia. Ésta última ha estado sustentada sobre el conocimiento empírico y sobre una concepción positivista del saber. Su neutralismo axiológico, su verificación empírica y su reiteración estadística han exiliado a la enfermedad y al enfermo al ámbito científico-técnico.

La medicina narrativa, por el contrario, permite acceder al mundo vivido por el paciente modificando la relación entre médico y enfermo. Lejano queda ya el paternalismo y las mentiras piadosas, así como la despersonalización del sujetoobjeto. En la bioética, aparece la ética del mundo vivido frente a las abstracciones de las éticas esencialistas. Resulta necesario un retorno al mundo cotidiano del enfermo en el que se percibe como una identidad concreta e intransferible. El paciente deja de ser un número de historial, una cosa, y el diálogo es un ir más allá del cuerpo, en palabras de GómezHeras, dolorido.

La autonomía del paciente brilla con más fuerza que nunca, puesto que es mediante sus relatos donde se le permite realizar la reflexión y la posterior interpretación por parte del médico. Ante una sociedad cada vez más tecnificada, aparece la medicina narrativa como un revulsivo ante las situaciones de deshumanización de la praxis facultativa, donde cabe preguntarse, como muy bien hace el autor, si la tecnología puede solventar todas las dimensiones de la enfermedad y la salud.
Y es que el conocimiento científico se encuentra ante límites que no puede superar. Es necesaria una concepción de la enfermedad como construcción axiológica que es verbalizada por las narraciones. La enfermedad se torna, así, un complejo holístico que incluye los datos de la ciencia más los relatos del paciente y del médico. Mediante estos relatos, el facultativo accede a unas informaciones que no son empíricas, pero sí muy valiosas, para tratar al enfermo, entre las que se encuentran las vivencias personales y las convicciones sociales. Es necesario superar la racionalidad instrumental y la burocratización de la enfermedad para rescatar la dimensión humana de la situación clínica. El enfermo es el gestor de su dolencia frente a los excesos economicistas, tecnológicos y administradores de la salud.

En conclusión, la ética narrativa encuentra su aplicación en la relación entre médico y paciente, eje central en la bioética. La comunicación entre médico y paciente tiene lugar a través del diálogo hablado. Es aquí donde la ética vincula el proceso de la enfermedad al lenguaje. El modelo humanista se postula como una ética en la que «dos más dos no son cuatro». Y la enfermedad se sitúa en la autobiografía, donde el relato aparece como procedimiento de rescate de valores. Gómez-Heras es claro: es necesaria una regresión fenomenológica al mundo personal y social vivido por el enfermo y el médico, y donde la hermenéutica encuentra su campo de aplicación. Todos los campos en los que el paciente tenga algo que decir, en cuanto sujeto protagonista del acto sanitario. Sólo así se accederá al conjunto de la dimensión humana de la enfermedad y del enfermo donde la bioética encuentra su nicho.

Mónica Delgado Carreira Universitat Autònoma de Barcelona http://dx.doi.org/10.5565/rev/enrahonar.244 
Pérez-Borbujo, Fernando (ed.) (2013)

Ironía y destino: La filosofía secreta de Søren Kierkegaard

Barcelona: Herder, $272 \mathrm{p}$.

ISBN 978-84-254-3086-2

«I tant de bo que cap grumet no descarregui la mà dialèctica sobre aquest treball, sinó que el deixi estar com està ara.»

Søren KierkegaArd, Una primera $i$ darrera explicació

A la presentació del número 29 d'aquesta mateixa revista, Begonya Saez, seguint Pseudonymie et paradoxe (París: Vrin, 1976), d'André Clair, resumia les posicions hermenèutiques majoritàries que s'han pres per aproximar-se a l'obra de Søren Kierkegaard. A tall d'introducció, per situar els diferents articles que constitueixen el llibre que és objecte d'aquesta ressenya, en faré un breu repàs.

En primer lloc, Saez presenta les lectures que interpreten l'obra de Kierkegaard basant-se en la seva vida, que podem distingir en biogràfiques $i$ existencials, de caràcter més general, i psicoanalitiques $i$ psiquiàtriques, més específiques i tècniques. En segon lloc, trobem les posicions hermenèutiques que s'hi aproximen estudiant el context. En aquest grup, d'una banda, trobem les lectures socials i politiques, que intenten comprendre l'obra en el seu marc social i cultural. I, de l'altra, les històriques i genètiques, que estudien Kierkegaard a partir de les polèmiques amb els seus adversaris i del diàleg amb els seus aliats. Finalment, també hi ha les lectures estrictament temàtiques, que analitzen els conceptes kierkegaardians, repassant-los transversalment al llarg de l'obra — una obra que, tanmateix, és voluntàriament asistemàtica-, per buscar-ne finalment la unitat en un exercici de síntesi que n'harmonitzi els conflictes. Les lectures teològiques, que pretenen trobar-hi un sentit a partir del pensament cristià, en són un bon exemple.

Més enllà de les virtuts que tenen aquestes posicions hermenèutiques, con- sidero, d'acord amb Clair i Saez, que defugen el compromís amb els aspectes formals de l'obra, com la ironia i la comunicació indirecta, ja que, tant si sorgeixen de la vida, del context o del discurs, no analitzen el text qua text. I és que, com en els diàlegs socràtics, el mètode utilitzat en la comunicació és essencial per apropar-se al contingut. Pel que fa a la pseudonímia, per exemple, convé no oblidar que, com afirma Johannes Climacus a Una darrera i primera explicació (publicat també al número 29 d'Enrahonar), Kierkegaard no és simplement un autor, sinó un creador d'autors que tenen veu pròpia. Així, quan es pretén trobar un sentit unitari als seus textos, polint-ne les tensions i interpretant-los biogràficament, psicològicament o temàticament, es corre el perill de reduir l'estratègia dels pseudònims a una anècdota irrellevant, amb la qual cosa es passaria per alt el desig que ell mateix expressa: "[...] que si mai algú s'entossudís a citar alguna manifestació dels llibres, en fes el favor de citar el nom del respectiu autor pseudònim, no el meu, o sia, que escindís així entre nosaltres [...]» (p. 161). És evident, doncs, que la pseudonímia «[...] no ha tingut un fonament casual en la meva persona [...], sinó un d'essencial en la producció mateixa [...]» (p. 159). Per tant, atribuir el contingut de les obres pseudònimes a l'autor Søren Kierkegaard implica forçar-ne el llegat.

Aquesta crítica és compartida per Roger Poole a Kierkegaard: The indirect communication (University of Virginia Press, 1993), on defensa que l'estratègia retòrica del pensador danès fa brollar dels seus textos una multiplicitat de lectures $i$ no pas una de sola que pugui ser considerada correcta, de manera que pretendre trobar un sentit unitari al llarg de la seva 
obra — com intenten les lectures temàtiques- és una actitud ingènua, il.lusòria i simplista. Segons Poole, Kierkegaard no escriu amb la intenció d'afirmar una veritat o d'oferir un sistema definitiu. I, en canvi, una part de la literatura secundària ha deixat de banda els mecanismes retòrics de la seva obra com si fossin una molèstia que, tanmateix, no impedeix arribar a una doctrina coherent i definida. El problema, afirma, és que molts intèrprets han buscat tan desesperadament el significat de la seva obra que no han tingut en compte la forma. De fet, com ens recorda Saez, Poole defineix com a "grollera" qualsevol lectura que passi per alt l'estatus literari dels textos i que arraconi el Kierkegaard estilista i retòric. Al capdavall, creu que la comunicació indirecta és un misteri impenetrable. I és que, com sembla insinuar Victor Eremita al pròleg de $O$ lo uno o lo otro (Madrid: Trotta, 2006) quan relata el seu atac al secreter amb una destral, l'intent de "penetrar» en els secrets que amaga un text implica destrossar-lo a través de l'anàlisi. Com afirma Eremita, "per aquests papers val en sentit estricte el que s'acostuma a dir de tots els assumptes impresos: callen» (p. 37).

En definitiva, doncs, les lectures que hem vist fins ara busquen el què del text. Però hi ha altres posicions hermenèutiques que, partint de la crítica a les anteriors, se centren en com cal llegir-lo. En mostro dos exemples. El primer, la lectura estructural de Clair, que, sense excloure cap de les estratègies de les primeres, es fonamenta en una anàlisi de l'estructura interna de l'obra, considerant així el text qua text, estudiant-lo no només des d'una perspectiva filosòfica, sinó també literària. I, el segon, la lectura estètica que proposa Saez, que prové alhora de l'estructural de Clair i de la desconstructiva de Poole, ja que, d'una banda, s'enfronta al text com a text i, de l'altra, s'hi aproxima com a discurs. Aquestes lectures es deixen fer pel text en lloc de buscar-hi una idea prèvia, no fan els ulls grossos davant la retòrica, la ironia o els pseudònims i estableixen una relació amb cada text qua text, sense pressuposar que contenen una unitat donada per un jo que vol transmetre una doctrina determinada.

En qualsevol cas, més enllà de les diferències metodològiques, la diversitat hermenèutica posa de manifest que avui, dos-cents anys després del naixement de Søren Kierkegaard, el seu pensament segueix despertant un gran interès. Ironía y destino: La filosofia secreta de Søren Kierkegaard (Barcelona: Herder, 2013) n'és un bon exemple. L'editor, Fernando Pérez-Borbujo, remarca l'hermetisme del filòsof danès i l'assenyala com a possible causa d'aquest interès. La seva filosofia, afirma, és una filosofia del secret. I això, segons ell, és alhora la seva gran virtut i la seva gran debilitat, ja que ha generat una enorme quantitat d'interpretacions sovint contraposades. En efecte, a Kierkegaard se l'ha considerat pare de l'existencialisme, filòsof hedonista, crític del hegelianisme i de l'idealisme, defensor del liberalisme, enemic de l'Església danesa i del cristianisme de la seva època, desconstruccionista avant la lettre, precedent de la metaliteratura, etc. Partint d'aquí, l'obra que ens ocupa pretén ser una mira$\mathrm{da}$ contemporània i polièdrica que reivindica l'actualitat i la riquesa del seu pensament, tot oferint-nos una mostra de la producció hermenèutica de l'última dècada a través de cinc assaigs d'orientació més o menys variada, que repassarem a continuació.

A l'article que enceta el llibre, Jon Stewart, catedràtic del Centre d'Investigació Søren Kierkegaard de la Universitat de Copenhaguen, utilitza el mètode de la Quellenforschung - la investigació de les fonts originals - per revisar críticament alguns tòpics i situar el pensador danès en el seu context. L'objectiu que persegueix és fer un advertiment metodològic que ens permeti determinar amb precisió què el preocupava i qui eren els autèntics destinataris de les seves polèmiques. I és 
que, segons Stewart, el desconeixement sobre Kierkegaard, el seu context històric $i$ les seves fonts originals han generat moltes confusions, la majoria de les quals relacionades amb la clàssica oposició a la filosofia hegeliana. Stewart presenta un seguit de proves que mostren que moltes de les crítiques que tradicionalment es creien dirigides a Hegel s'adreçaven més aviat a la recepció d'aquest per part d'alguns coetanis de Kierkegaard, com ara Martensen, Adler, Heiberg i Grundtvig. En definitiva, aquest assaig —que comparteix les característiques de les lectures socials i polítiques, com també de les històriques i genètiques - ofereix eines molt útils per apropar-se a l'obra de Kierkegaard, eines que poden interessar tant als iniciats com als neòfits i que, com afirma Stewart, tenen l'avantatge que es poden combinar amb altres metodologies.

El segon article, a càrrec de Jacobo Zabalo, és un estudi de l'esfera estètica -més concretament, de l'aprehensió estètica de l'existència-, que, segons el professor de la Universitat Pompeu Fabra, es caracteritza per la malenconia - viscuda pel mateix Kierkegaard com una mort en vida-, per la contradicció entre la idealitat del llenguatge i la immediatesa de la realitat, pel joc entre la veritat i l'ocultació i per la contradicció entre el desig i la impossibilitat de saciar-lo. Això empeny Zabalo a investigar no només el contingut, sinó també alguns elements formals que esdevenen fonamentals en l'obra de Kierkegaard, com ara la ironia i els pseudònims. Tot plegat ho exemplifica a partir de la figura de Don Giovanni i amb referències constants a Camus, Nietzsche, Freud, Lacan, Ricoeur i Žižek, entre d'altres pensadors. En suma, una lectura entre biogràfica, temàtica i estructural que, mentre examina l'angoixa, el desig i la recerca de l'eternitat en l'instant, aprofundeix en la funció reparadora de la ficció literària.

D’altra banda, María J. Binetti realitza una anàlisi transversal de l'acció ètica i de la noció kierkegaardiana de llibertat en les tres esferes de l'existència, que, segons la investigadora del CONICET, és crítica amb la romàntica i està en continuïtat amb la de l'idealisme. Per Kierkegaard, el romanticisme té una concepció negativa i nihilista de la infinitud de la llibertat subjectiva, ja que defuig qualsevol compromís amb la finitud i no assumeix l'escissió que suposa fer-se concreta. Així, en els diversos sentits que, per l'autora, té allò que és ètic en el pensador danès, hi trobem un denominador comú: la posada en acte i en finitud d'una llibertat infinita. El problema de la llibertat en Kierkegaard no és l'eticitat del lliure albir, de les accions finites o de triar entre el bé o el mal, sinó el fet d'escollir el mateix voler originari. La qüestió és el caràcter ètic i dialèctic d'una llibertat que té com a objecte la lliure creació del jo. L'ètica kierkegaardiana, conclou l'article, és una ètica de l'acció absoluta que intenta fer una síntesi entre Sòcrates i Crist.

Francesc Torralba ens ofereix, en el quart article, una lectura marcadament teològica a partir de l'anàlisi del text «En ocasió d'una confessió", inclòs a Tres discursos en ocasions suposades - que, per cert, Proteus va editar en català amb un pròleg del mateix professor de la Universitat Ramon Llull. Sintèticament, els temes que hi desenvolupa són: la recerca de Déu, les concepcions de la divinitat o les etapes que s'han de superar per arribar-hi, la relació entre Déu i l'home, la pregària, els graus de coneixement, els límits de la raó i la ciència, la fe com a revelació interior, l'anàlisi dels conceptes d'ésser ideal i ésser factic i la crítica a les demostracions de l'existència de Déu. Amb un estil divulgatiu, Torralba ens vol apropar al cristianisme d'un filòsof, que, tanmateix, va criticar amb ferocitat l'Església institucionalitzada.

L'últim article, signat per Luis Guerrero, president de la Societat Iberoamericana d'Estudis Kierkegaardians, vol demostrar la importància que van tenir per 
Kierkegaard la problemàtica i la crítica social, qüestions centrals de la seva filosofia que sovint s'han passat per alt. En aquesta lectura temàtica de dimensió social, Guerrero reivindica el compromís ètic i religiós de Kierkegaard amb el seu temps i l'actualitat de les seves reflexions. A partir de l'anàlisi de Sobre el concepte d'ironia, El concepte de l'angoixa i L'època present, examina la visió de la ironia socràtica — signe del final d'una època-, la filosofia de la història i la relació dialèctica entre l'individu i l'espècie $i$, finalment, la crítica a la manca d'implicació i apassionament, que és conseqüència de la pèrdua en la fantasia $i$ la reflexió $i$ que condueix al triomf de la massa sobre l'individu compromès.

En síntesi, doncs, Ironía y destino: $\mathrm{La}$ filosofia secreta de Søren Kierkegaard constitueix una bona oportunitat d'apropar-se a algunes de les línies d'estudi més recents sobre el pensador danès. A banda de si s'està d'acord o en desacord amb els posicionaments hermenèutics dels autors dels articles, i més enllà de si aconsegueix o no penetrar en els secrets de la filosofia de Søren Kierkegaard, el llibre és un instrument enriquidor que ens permet celebrar els dos-cents anys del seu naixement i constatar la bona salut i la profunditat insondable dels seus textos.

Roger Mas Soler Universitat Autònoma de Barcelona http://dx.doi.org/10.5565/rev/enrahonar.102 



\section{Llibres rebuts}

Byung-Chul Han (2014). La agonía del Eros. Traducció de Raúl Gabás. Barcelona: Herder. Pensamiento Herder. 79 p.

Campillo, Neus (2013). Hannah Arendt: Lo filosófico y lo político. València: Publicacions de la Universitat de València. Primas, 5. 293 p.

Candel, Miguel (2013). Tiempo de eternidad: Reflexiones sobre y desde la filosofía antigua. Barcelona: Montesinos. $357 \mathrm{p}$.

Caràcters, 62 (hivern de 2013), 48 p.; 63 (primavera de 2013), 48 p.; 64 (estiu de 2014), 48 p.; 65 (tardor de 2014), 48 p.

Diàlegs: Revista d'Estudis Polítics i Socials, 63 (2014). 115 p.

FErrara, Alessandro (2014). El horizonte democrático: El hiperpluralismo y la renovación del liberalismo político. Traducció d'Antoni Martínez Riu. Barcelona: Herder. Pensamiento Herder. 431 p.

Higuera Rubio, José (2014). Física y teología (atomismo y movimiento en el Arte luliano). Bellaterra: Institut d'Estudis Medievals. Universitat Autònoma de Barcelona.

MèLıch, Joan-Carles (2014). Lógica de la crueldad. Barcelona: Herder. 264 p. Tanabe Hajime (2014). Filosofía como metanoética. Traducció de Rebeca Maldonado amb Andrés Marquina, Sasha Jair Espinosa i Cristina Pérez. Barcelona: Herder. 418 p. 
